Morfologia pretarsal, anatomia cefálica, e a evolução de Cholevinae (Coleoptera: Leiodidae)

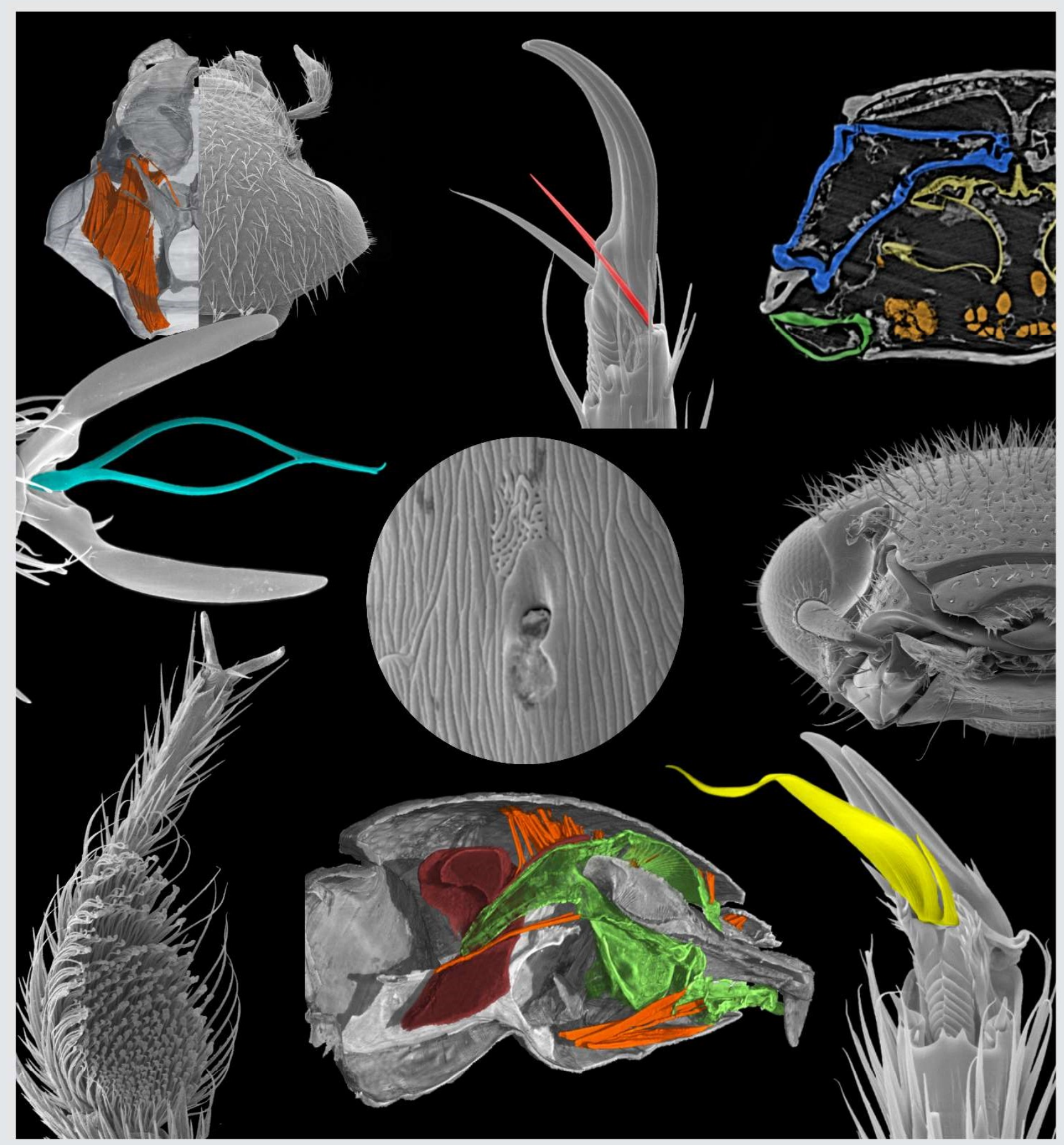

Caio Antunes de Carvalho 


\section{MORFOLOGIA PRETARSAL, ANATOMIA CEFÁLICA, E A EVOLUÇÃO DE CHOLEVINAE (COLEOPTERA: LEIODIDAE)}

\section{PRETARSAL MORPHOLOGY, CEPHALIC ANATOMY, AND THE EVOLUTION OF CHOLEVINAE (COLEOPTERA: LEIODIDAE)}





\section{MORFOLOGIA PRETARSAL, ANATOMIA CEFÁLICA, E A EVOLUÇÃO DE CHOLEVINAE (COLEOPTERA: LEIODIDAE)}

\section{PRETARSAL MORPHOLOGY, CEPHALIC ANATOMY, AND THE EVOLUTION OF CHOLEVINAE (COLEOPTERA: LEIODIDAE)}

\section{Caio antunes de Carvalho}

Tese apresentada ao Instituto de Biociências da Universidade de São Paulo, para a obtenção do Título de Doutor em Ciências, na Área de Zoologia.

Orientador: Prof. Dr. Pedro Gnaspini 



\section{FICHA CATALOGRÁFICA}

Carvalho, Caio Antunes de.

Morfologia pretarsal, anatomia cefálica e a evolução de Cholevinae /

Caio Antunes de Carvalho ; orientador Pedro Gnaspini. --São Paulo, 2017.

$238 \mathrm{f}$.

Tese (Doutorado) - Instituto de Biociências da Universidade de São Paulo. Departamento de Zoologia.

1. Staphylinoidea. 2. Staphyliniformia. 3. Filogenia. I. Universidade de São Paulo. Instituto de Biociências. Departamento de Zoologia.

II. Título.

\section{COMISSÃO JULGADORA}

Prof. Dr. Pedro Gnaspini:

(orientador)

$\operatorname{Prof}(a) \cdot \operatorname{Dr}(a)$ :

$\operatorname{Prof}(a) \cdot \operatorname{Dr}(a)$ :

$\operatorname{Prof}(a) \cdot \operatorname{Dr}(a):$

$\operatorname{Prof}(a) \cdot \operatorname{Dr}(a):$ 

PARA MEUS PAIS,

E PARA PRISCILA 

IT IS THE MYSTERY AND BEAUTY OF ORGANIC FORM THAT SETS THE PROBLEM FOR US.

Ross G Harrison (1913) 



\title{
AGRADECIMENTOS
}

\author{
À Fundação de Amparo à Pesquisa do Estado de São Paulo (FAPESP) pela \\ concessão da bolsa de Doutorado (\#2012/19002-0), e pela bolsa de Estágio de \\ Pesquisa no Exterior (BEPE \#2014/22088-0). Esses recursos foram vitais para o \\ desenvolvimento deste trabalho.
}
A Pedro Gnaspini, quem me orientou na condução do projeto, por ter desde o início confiado em meu trabalho e me dado autonomia, ao mesmo tempo estendendo sua mão para o que fosse preciso. Agradeço pelo comprometimento, pela paciência e parceria.

\begin{abstract}
A todos aqueles que nos receberam em suas instituições e nos auxiliaram durante o exame das coleções pelas quais são responsáveis, aos que nos receberam em suas casas e abriram para nós as portas de suas coleções particulares, e aos que nos enviaram exemplares: Alfred F. Newton (Field Museum of Natural History, Chicago, USA), Andrea Colla (Museo Cívico di Scienze Naturali, Trieste, Italy), Cristiano Lopes Andrade (Universidade Federal de Viçosa, Viçosa, Brasil), Fabrizio Rigato (Museo di Storia Naturale di Milano, Milano, Italy), Ignacio Ribera (Instituto de Biología Evolutiva, CSIC-Universitat Pompeu Fabra, Barcelona, Spain), Jan Rưžička (Czech University of Life Sciences, Praha, Czech Republic), Jirí Hájek (Národní muzeum Praha, Czech Republic), Johannes Frisch (Museum für Naturkunde Berlin, Germany), Michel Perreau (Université Paris 7, Paris, France), Pier Mauro Giachino (Settore Fitosanitario Regionale, Torino, Italy), Richard Leschen (Landcare Research, Auckland, New Zealand), Sônia Casari (Museu de Zoologia da Universidade de São Paulo, São Paulo, Brasil), Stefano Zoia (Milano, Italy), Stewart Peck (Carleton University, Ottawa, Canada), e Thierry Deuve (Muséum National d'Histoire Naturelle, Paris, France).
\end{abstract}

To Rolf Beutel, who supervised my internship in Jena, for the invaluable support. His collaboration has been intellectually stimulating.

To Ignacio Ribera, for his valuable suggestions and significant contribution.

To all members of the Entomology Group (Institut für Spezielle Zoologie and Evolutionsbiologie, FSU Jena, Germany) for their kind assistance during my internship in Jena. I especially thank Hans Pohl and Margarita Yavorskaya for their generous support.

Ao Instituto de Biociências da Universidade de São Paulo e ao Institut für Spezielle Zoologie und Evolutionsbiologie mit Phyletischem Museum da Friedrich-SchillerUniversität (Jena, Alemanha), instituições nas quais o projeto foi executado.

Ao Laboratório de Microscopia Eletrônica do IB-USP e à Márcio V. Cruz pela assistência no uso do miscroscópio eletrônico de varredura. 
Aos amigos de São Paulo, amizades indeléveis, que tão bem me acolheram na terra da garoa. Vocês sempre farão parte de todas as memórias da vida que tive em sampa. Aliás, vocês desde o início foram parte dela. Agradeço especialmente a Alípio, Caqui, Mamilo, Sabrina, Zé \& Carol, e aos muitos outros que conheci através destes.

Aos meus pais, Valéria e Rivo, pela constante motivação, amparo, e por estarem sempre por perto, mesmo quando em lados opostos do Altântico.

Ao meu brother, Sandro, agradeço pela eterna parceria e amizade inabalável. À Priscila, minha fonte de tranquilidade e valores, os quais sempre me inspiraram. Agradeço pela compreensão e incentivo. Sua companhia me trouxe serenidade e me encorajou a seguir em frente. 


\section{SUMÁRIO}

$\begin{array}{ll}\text { RESUMO } & 15\end{array}$

$\begin{array}{ll}\text { ABSTRACT } & 16\end{array}$

$\begin{array}{ll}\text { INTRODUÇÃO GERAL } & 17\end{array}$

CAPÍTULO 1

Pretarsus and distal margin of the terminal tarsomere as an unexplored character system for higher-level classification in Cholevinae (Coleoptera, Leiodidae)

CAPÍTULO 2

Cephalic anatomy and three-dimensional reconstruction of the head of Catops ventricosus (Weise, 1877) (Coleoptera: Leiodidae: Cholevinae)

CAPÍTULO 3

Morphology-based phylogenetic reconstruction of Cholevinae (Coleoptera: Leiodidae) - a new view on higher-level relationships

CAPÍTULO 4

Show me your tenent setae and I tell you who you are - Telling the story of a neglected character complex with phylogenetic signals using Leiodidae (Coleoptera) as a case study 



\section{RESUMO}

Leiodidae é a segunda maior família de besouros de Staphylinoidea, com mais de 4100 espécies e 374 gêneros abrigados em seis subfamílias. Com representantes em terras tropicais e temperadas, Cholevinae é a mais diversa, compreendendo cerca de 2050 espécies agrupadas em sete tribos e 17 subtribos. Esta tese tem como propósito testar a unidade de Cholevinae, lançar luz sobre suas relações supragenéricas internas, e fornecer evidências morfológicas para futuras inferências sobre o relacionamento de grandes grupos de Leiodidae. O capítulo 1 explora o potencial da morfologia do pretarso e margem distal do tarsômero terminal como fonte de caracteres para a sistemática de Cholevinae. Diversas características são descritas e documentadas pela primeira vez, e suas implicações filogenéticas são discutidas. No capítulo 2 examinamos em detalhes, e pela primeira vez, os componentes morfológicos cefálicos, internos e externos, de um representante de Cholevinae. Comparações com outras linhagens de Staphyliniformia sugerem que a anatomia cefálica é altamente conservada no grupo. Um modelo tridimensional da cabeça é apresentado, e diversas estruturas são descritas e discutidas de um ponto de vista filogenético. Este trabalho oferece bases para pesquisas subsequentes interessadas em investigar as relações entre grandes grupos de Leiodidae tendo por base caracteres da cabeça. Os dados fornecidos nesses estudos são empregados no capítulo 3, que trata diretamente da análise filogenética de Cholevinae, não apenas com base na morfologia pretarsal e cefálica, mas também lançando mão de uma série de novos caracteres obtidos através do estudo de outras partes do corpo. Uma hipótese filogenética para a subfamília é apresentada, a mais completa até então, e a primeira fundamentada em caracteres morfológicos. No capítulo 4, Cholevinae é colocado em um espectro mais amplo. Neste estudo, analisamos o valor informativo das cerdas tarsais sexuais para a sistemática de Leiodidae como um todo. Quatro tipos morfológicos principais dessas cerdas foram reconhecidos com base em variações na forma e disposição dessas estruturas. A distribuição desses caracteres é discutida tendo em vista as relações supragenéricas da família, demonstrando que várias das estruturas em questão suportam o monofiletismo de alguns grupos. Uma ampla compilação de dados da literatura envolvendo as cerdas estudadas é fornecida. 


\section{ABSTRACT}

Leiodidae is the second most species-rich family of staphylinoid beetles, with more than 4100 species and 374 genera organized in six subfamilies. With representatives in tropical and temperate lands, Cholevinae is the most diverse subfamily and comprises more than 2000 species grouped into seven tribes and 17 subtribes. This contribution aims to test the monophyly of Cholevinae, to shed light on its internal suprageneric relationships, and to provide morphological evidences for future inferences on higher-level relationships within Leiodidae. Chapter 1 explores the potential of the pretarsal morphology and distal margin of terminal tarsomere as a source of characters for the systematics of Cholevinae. Several features are described and documented for the first time, and their phylogenetic implications are discussed. In chapter 2, we examine the internal and external components of the cephalic morphology of a representative of Cholevinae. Comparisons with other Staphyliniform lineages suggest that the cephalic anatomy is highly conserved in this group. A three-dimensional model of the head is presented, and various structures are described and discussed from a phylogenetic point of view. This study offers the bases for future works interested in the investigation of higher-level relationships in Leiodidae using cephalic structures as a source of characters. The data provided by these investigations are employed in chapter 3, which deals directly with the phylogenetic analysis of Cholevinae not only based on the pretarsal and head morphology, but also on the study of other characters from different body structures. A phylogenetic hypothesis for the subfamily is presented, the most comprehensive so far, and the first based on morphology. In chapter 4, Cholevinae is placed in a broader spectrum. In this chapter, we analyzed the informative value of the tenet setae for the systematics of Leiodidae as a whole. Four morphological types of tenent setae were recognized based on variation of shape and arrangement. The distribution of characters within Leiodidae is discussed, demonstrating that many of the structures under consideration support the monophyly of different groups. Additionally, a broad literature review on the studied characters is presented. 
I NTR O D U Ç Ã O

GERA L 



\section{Cholevinae (Staphylinoidea: LeIODIDAe): UMA BREVE APRESENTAÇÃO}

eiodidae é a segunda maior família de besouros de Staphylinoidea, com cerca de 4135 espécies e 374 gêneros abrigados em seis subfamílias (Newton, 2016): Camiarinae, Catopocerinae, Leiodinae, Coloninae, Cholevinae e Platypsyllinae. Possuem distribuição cosmopolita e são capazes de explorar um eclético repertório de hábitats e recursos alimentares. Contudo, em geral, leiodídeos vivem em áreas de floresta e podem ser saprófagos, alimentando-se de algum tipo de matéria orgânica animal ou vegetal em decomposição (e.g. serapilheira, fezes, carcaças), ou micófagos, associando-se a diferentes grupos de fungos.

Com representantes em terras tropicais e temperadas, Cholevinae é a subfamília mais diversa, compreendendo cerca de 2050 espécies agrupadas em sete tribos e 17 subtribos (Fig. 1). Embora não sejam esteticamente atraentes aos olhos de entomólogos acostumados com besouros grandes e vistosos, os colevíneos são provavelmente os leiodídeos mais estudados. Suas espécies podem ser encontradas em uma vasta diversidade de ambientes. A maioria desses besouros vive associada ao solo e à serapilheira, ou em ambientes de caverna e solo profundo. Várias espécies apresentam modificações morfológicas como reflexo desse cenário, como por exemplo a redução ou perda de olhos e asas posteriores. Algumas espécies são frequentemente coletadas em ninhos de insetos sociais como formigas e vespas (Peck \& Cook 2002, 2007), enquanto outras podem ser obtidas em tocas de cágados, corujas, raposas, toupeiras e diversos grupos de roedores (Jeannel 1936, Newton 1998, Peck \& Skelley 2001).

A primeira tentativa de organizar este grupo com base em uma interpretação filogenética explícita foi realizada pelo especialista francês Renné Jeannel, no início do século passado (Jeannel 1911, 1924, 1936, 1955). Depois do pontapé inicial de Jeannel, outras propostas e discussões de classificação de Cholevinae foram apresentadas por diferentes autores (e.g. Szymczakowski 1964, Perreau 1989, 
Giachino \& Vailati 1993, Giachino et al. 1998, Newton 1998). A de Newton (1998) é atualmente a mais utilizada, e foi construída tendo por base hipóteses de sinapomorfia fundamentadas na avaliação de caracteres morfológicos. Essas várias propostas apresentam diferentes hipóteses de relacionamento entre subgrupos de Cholevinae, em grande parte como consequência de interpretações contrastantes sobre a morfologia. As características usadas por esses autores, contudo, são predominantente oriundas do universo do trabalho taxonômico, sendo em sua maioria estruturas de fácil visualização ou variações da genitália. O conhecimento sobre a morfologia de Cholevinae, portanto, estava restrito a este contexto.

Estudos recentes com base em dados moleculares lançaram visões alternativas sobre as relações internas em Cholevinae (e.g. Fresneda et al. 2011, McKenna et al. 2015). No entanto, nenhum desses trabalhos teve a subfamília como foco. $O$ propósito de McKenna et al. (2015) foi reconstruir a filogenia de Staphyliniformia e (pelo menos em parte) Scarabaeiformia, grupos extraordinariamente diversos que juntos somam mais de 100.000 espécies. Em Fresneda et al. (2011), o objetivo principal foi testar a afinidade de três gêneros de Leptodirini com os demais membros da tribo. Portanto, ambos estudos possuem uma amostragem taxonômica insuficiente para se testar a monofilia de Cholevinae e propor uma hipótese de relacionamento para seus subgrupos. A classificação da subfamília ainda carece de sustentação filogenética.

$\rightarrow$ Fig. 1 Diversidade morfológica em Cholevinae. (A-E) Anemadini: (A) Anemadus graecus (Anemadina), (B) Micronemadus pussilimus (Nemadina), (C) Eocatops ophidianus (Eocatopina), (D) Paracatops antipoda (Paracatopina), e (E) Falkonemadus sp. (Eunemadina). (F, G) Cholevini: (F) Dreposcia umbrina (Catopina) e (G) Prionochaeta harmandi (Cholevina). (H) Eucatopini: Eucatops sp. (I) Oritocatopini: Chappuisiotes lobeliae. (J, K) Ptomaphagini: (J) Proptomaphaginus puertoricensis (Ptomaphaginina) and (K) Ptomaphagus sericatus (Ptomaphagina). (L) Sciaphyini: Sciaphyies sibiricus. (M-S) Leptodirini: (M) Platycholeus leptinoides (Platycholeina), (N) Pisidiella kosswigi (Bathysciina), (O) Neobathyscia fabianii (Bathysciotina), (P) Elladoherpon inopinatum (Leptodirina), (Q) Pholeuon knirschi (Pholeuina), (R) Spelaeobates kraussi (Spelaeobatina), and (S) Hadesia vasiceki (Anthroherponina). Escala $=0,5 \mathrm{~mm}$. 


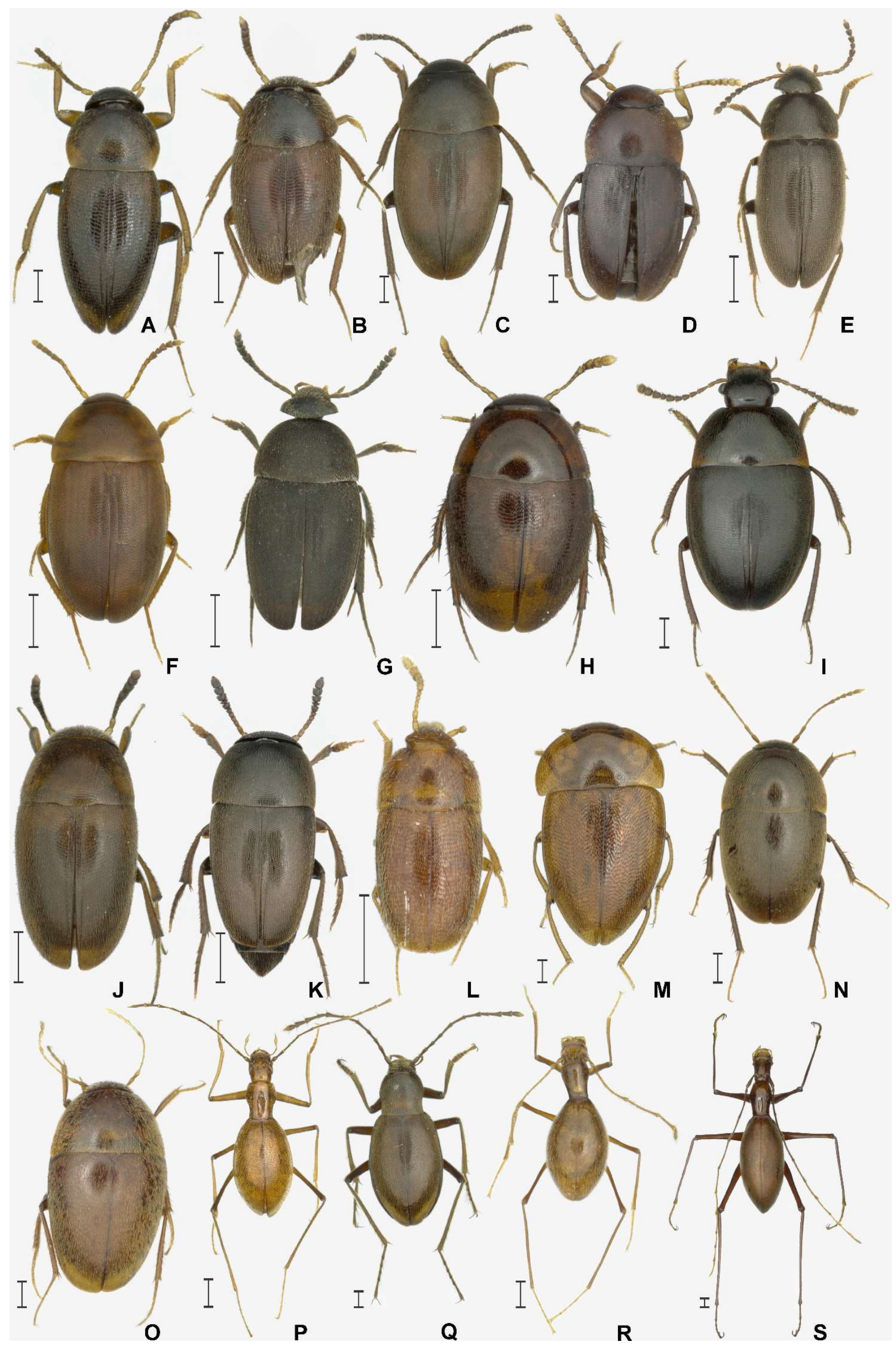




\section{O ESTUDO DO TARSO E PRETARSO EM INSETOS - INTRODUÇÃO, MORFOLOGIA GERAL E TERMINOLOGIA}

Assim como o voo, a capacidade de escalar superfícies lisas ou de andar no teto é uma das habilidades dos insetos que há muito desperta a atenção de cientistas, observadores da natureza e curiosos em geral. Essa capacidade deve-se principalmente às estruturas de adesão presentes nos tarsos e pretarsos dos insetos. Esse campo de pesquisa tem uma longa história, que remonta ao século dezenove (e.g. West 1862, Dewitz 1883, Dahl 1884, Rombouts 1884, Simmermacher 1884) e contempla variados e interessantes tópicos de investigação como morfologia funcional (Betz \& Munn 2001), secreção tarsal (Attygalle et al. 2000, Kölsch 2000, Betz 2003), física envolvida no processo de adesão (Dixon et al. 1990, Jiao et al. 2000), comportamento animal (Betz \& Kölsch 2004), morfologia geral e ultraestrutura (Gorb 2001, Gorb \& Beutel 2001).

O tarso e pretarso dos insetos são compostos por diversos elementos que variam substancialmente entre táxons. Devido a este fator, ao pequeno tamanho e ao parco conhecimento dos componentes tarsais e pretarsais, equívocos terminológicos volumaram-se na literatura entomológica. Após algumas discussões terminológicas (e.g. Crampton 1923, Levereault 1935), um glossário com os termos mais usados nas diversas ordens de inseto foi apresentado por Dashman (1953a), o qual foi recentemente aprimorado e atualizado por Beutel \& Gorb (2001). Assim, o tarso refere-se à parte distal da perna e compreende de 1 a 5 tarsômeros. O tarsômero proximal (geralmente o mais longo) é chamado de basitarso, enquanto o tarsômero distal é chamado de tarsômero terminal ou distitarso. O pretarso lou pós-tarso) é a parte terminal da perna, localizado junto à margem distal do tarsômero terminal. Na maioria dos insetos é composto por um par de garras lou unhas) e geralmente por um lóbulo mediano, o arólio, que pode ser membranoso ou parcialmente esclerotizado e conter componentes estruturais particulares. Ventralmente ao pretarso encontra-se uma placa basal esclerotizada, a placa unguitratora (ou unguitrator), que se abriga dentro do tarsômero terminal e pode 
conter distalmente um esclerito adicional, a planta. Escleritos laterais (escleritos auxiliares ou auxiliae) podem estar presentes próximos à base das garras. Partindo desses escleritos auxiliares, podem ocorrer lobos laterais, os pulvilos. Empódios tarsais, que podem ter a forma de espinhos ou lobos, podem surgir do ápice da placa unguitratora.

\section{O USO DE CARACTERES TARSAIS E PRETARSAIS EM TAXONOMIA E FILOGENIA}

O amplo espectro de variação morfológica das estruturas tarsais e (principalmente) pretarsais de insetos foi revelado em estudos antigos. Abordagens comparativas sobre a morfologia pretarsal e seu valor taxonômico foram realizadas por Meijere (1901) e Holway (1935), com representantes de diversas ordens de insetos. Holway (1935) incluiu discussões iniciais sobre hipóteses de homologia entre as estruturas pretarsais e considerou as variações observadas em Holometabola como de potencial relevância para elucidação de questões filogenéticas, registrando, por exemplo, a proximidade entre Trichoptera e Lepidoptera (sustentada por trabalhos recentes; e.g. Peters et al. 2014, Beutel et al. 2011).

Os estudos mais recentes têm integrado caracteres da morfologia tarsal e pretarsal a um contexto filogenético, alguns mapeando esses caracteres sobre topologias pré-existentes na literatura, e outros incorporando esses em matrizes com caracteres adicionais para a construção de filogenias. A grande maioria desses estudos tem sido conduzida utilizando-se de microscopia eletrônica de varredura, oferecendo uma maior riqueza de detalhes e melhor visualização dos componentes morfológicos.

O primeiro estudo amplo das estruturas tarsais e pretarsais integradas à inferência de relações filogenéticas em insetos foi realizado por Beutel \& Gorb (2001), os quais avaliaram a evolução de padrões morfológicos de estruturas de adesão baseado em uma filogenia das ordens de Hexapoda. Algumas estruturas 
suportaram grupos monofiléticos como Embioptera + Dermaptera, Dictyoptera + Phasmatodea + Grylloblattodea + Orthoptera, Dictyoptera + Phasmatodea, Hymenoptera + Mecopterida, e Neuropterida + Strepsiptera + Coleoptera, enquanto outras mostraram-se autapomórficas, como um tipo específico de almofadas presente nas garras de Ephemeroptera e a presença de almofadas protráteis em Thysanoptera. Embora sejam estruturalmente diversos, os sistemas de adesão tarsal e pretarsal de insetos resumem-se a dois tipos funcionais básicos superfícies pilosas e almofadas flexíveis lisas.

À luz de novos dados, Beutel e Gorb $(2006,2008)$ ampliaram o estudo inicial, com ênfase em Phasmatodea e Mantophasmatodea (ordem só descrita em 2002, por Klauss et al.), obtendo algumas interpretações contrastantes com o estudo anterior. A presença de tarsômeros pilosos passou a ser interpretada como aquisição independente em Embioptera e Dermaptera, e a presença de arólio como plesiomórfica em Endopterigota. Até então assumia-se que o arólio, presente na maioria das linhagens de Pterygota, tivesse sempre a superfície lisa, assim como as euplântulas, que ocorrem principalmente nos Neoptera basais (Beutel \& Gorb 2001). Esse panorama foi alterado pela recente descoberta de euplântulas e arólios com superfície recoberta por acantos (protuberâncias cuticulares em forma de espinho), presentes unicamente em Phasmatodea e Mantophasmatodea (Beutel \& Gorb 2006, 2008).

Investigações sobre a morfologia tarsal e pretarsal aplicadas à inferência de relações filogenéticas também foram realizadas em grupos menos inclusivos, como Acercaria (Friedemann et al. 2014), Dermaptera (Haas \& Gorb 2004), Diptera (Friedemann et al. 2014), Hymenoptera (Schulmeister 2003, Gladun \& Gumovsky 2006), Plecoptera (Nelson 2009) e Strepsiptera (Pohl \& Beutel 2004). Esses trabalhos demonstram que os caracteres tarsais e pretarsais podem fornecer informações filogenéticas também ao nível de família. Contrastando com as outras ordens, em Hemiptera, a diversidade da morfologia pretarsal tem sido profundamente explorada e documentada, seja por investigações focadas em táxons superiores (Dashman 1953b, Goel \& Schaefer 1970, Goel 1972, Hasan 1995, Friedemann \& Beutel 2014) ou comparando subgrupos dentro de uma família (Vasarhelyi 1986, 
Hasan 1990, Lis et al. 2002, Weirauch 2005, Lis 2010, Lis e Ziaja 2010, Barão et al. 2013). Como consequência desses esforços, o conhecimento sobre os caracteres do pretarso que possuem relevância para a sistemática do grupo, sobretudo de Heteroptera, tem se tornado cada vez mais evidente.

Através da análise do pretarso de representantes de várias famílias de Coleoptera, Hayes \& Kearns (1934) identificaram dois padrões morfológicos gerais com base em características da placa unguitratora e empódios tarsais. Membros da subordem Adephaga mostraram consistência morfológica, contrastando com a heterogeneidade observada em Polyphaga. Os autores também relataram uma tendência à uniformidade morfológica em direção a níveis taxonômicos inferiores, e citaram a necessidade de estudos adicionais nesses níveis para uma melhor avaliação do pretarso como ferramenta taxonômica. Diante da enorme diversidade de grupos de insetos, o conhecimento da morfologia tarsal e pretarsal e sua aplicabilidade em filogenias ainda é restrito.

\section{A MORFOLOGIA CEFÁLICA EM INSETOS, E SUAS IMPLICAÇÕES FILOGENÉTICAS}

O desenvolvimento de novas tecnologias pavimentou o caminho para o avanço do conhecimento sobre a anatomia de insetos. Dentre essas tecnologias, os métodos de reconstrução tridimensional (3D) vêm ganhando destaque entre morfologistas (Beutel \& Kristensen 2012, Trautwein et al. 2012, Wipfler et al. 2016). Como material base para a reconstrução, tanto técnicas inovadoras, como microtomografia computadorizada, quanto técnicas tradicionais, como histologia, podem ser utilizadas (Friedrich et al. 2014). A abordagem 3D melhorou notavelmente a visualização do arranjo espacial de estruturas complexas, como a cabeça, considerada o tagma mais complexo dos insetos. Além disso, acelerou o acesso a um valioso e extenso conjunto de dados antes de tamanho desconhecido, ou pelo menos subestimado (veja por exemplo a filogenia de Beutel et al. 2011, com 356 
caracteres). A despeito do seu potencial, essa técnica ainda se restrisge a poucos grupos de pesquisa em morfologia de insetos.

Estudos sobre a anatomia cefálica têm revelado interessantes insights para o conhecimento filogenético de diversos grupos de insetos (e.g. Friedrich et al. 2013, Spangenberg et al. 2013, Blanke et al. 2012, Wipfler et al. 2011), além de proporcionar uma melhor compreensão sobre o funcionamento do aparato alimentar. Em Coleoptera, a morfologia cefálica é relativamente bem conhecida em Archostemata (Beutel et al. 2008), Adephaga (Dressler \& Beutel 2010) e na família de mixófagos Lepiceridae. Contudo, em Polyphaga, clado mais diverso de besouros, as informações ainda são bastante fragmentadas. O mesmo se aplica a Staphyliniformia, que engloba uma fantástica variabilidade de hábitos alimentares e uma tremenda riqueza de espécies organizada em vários grandes grupos, dos quais apenas alguns já tiveram a morfologia cefálica estudada.

Cholevinae tem sido usado como um grupo externo em diversos estudos filogenéticos com foco no relacionamento de grandes grupos, tendo por base caracteres da cabeça (e.g. Polilov \& Beutel 2009; Beutel et al. 2010; Dressler \& Beutel 2010; Randolf et al. 2014). No entanto, sua morfologia cefálica nunca foi investigada em profundidade, sobretudo sua anatomia. Mesmo considerando-se as estruturas externas, há poucas imagens representativas para a subfamília, ainda que tanto Leiodidae quanto Cholevinae sejam sustentadas como monofiléticas com base em características da cabeça. Uma caracterização deste tagma permanece inexistente para o grupo, e comparações com outras linhagens de Staphylinoidea são portanto superficiais. 


\section{OBJETIVOS GERAIS E ORGANIZAÇÃO DA TESE}

O presente estudo está estruturado em quatro capítulos apresentados na forma de artigos. Dois dos capítulos ( 1 e 2) já foram publicados, enquanto os outros dois se encontram preparados para submissão (3 e 4).

Esta tese tem como propósito final testar a unidade de Cholevinae, lançar luz sobre suas relações supragenéricas internas, e fornecer evidências morfológicas para futuras inferências sobre o relacionamento de grandes grupos dentro Leiodidae. O capítulo 1 teve como objetivo explorar o potencial informativo da morfologia do pretarso e margem distal do tarsômero terminal para a sistemática da subfamília. Neste trabalho, diversas características são descritas e documentadas pela primeira vez, e suas implicações filogenéticas são discutidas. $\bigcirc$ objetivo do capítulo 2 foi examinar, em detalhes, os componentes morfológicos internos e externos da cabeça de um representante de Cholevinae. Este trabalho oferece elementos para estudos subsequentes interessados em investigar as relações envolvendo táxons de Leiodidae tendo por base caracteres da cabeça. Os dados fornecidos nesses dois estudos são empregados no capítulo 3, que trata diretamente da análise filogenética da subfamília. Este trabalho objetivou testar o monofiletismo de Cholevinae e inferir as relações supragenéricas no grupo, não apenas com base no pretarso e nas estruturas cefálicas, mas também lançando mão de uma série de novos caracteres obtidos através do estudo de outras partes do corpo, e incluindo informações da literatura.

No capítulo 4, Cholevinae é colocado em um espectro mais amplo. Neste estudo, analisamos o valor informativo das cerdas tarsais para a sistemática de Leiodidae como um todo, fornecendo evidências morfológicas para futuras inferências sobre o relacionamento de grandes grupos dentro da família. As principais implicações dos caracteres levantados neste estudo são discutidas tendo em vista as relações supragenéricas do táxon, demonstrando que várias das estruturas investigadas suportam o monofiletismo de alguns grupos em Leiodidae. Adicionalmente, é apresentado um amplo levantamento bibliográfico sobre os caracteres analisados. 


\section{REFERÊNCIAS}

Attygalle, A.B., Aneshansley, D.J., Meinwald, J. \& Eisner, T. 2000. Defense by foot adhesion in a chrysomelid beetle (Hemisphaerota cyanea): characterization of the adhesive oil. Zoology, 103: 1-6.

Barão, K., Ferrari, A. \& Grazia, J. 2013. Comparative morphology of selected characters of the Pentatomidae foreleg (Hemiptera, Heteroptera). Arthropod Structure \& Development, 42: 425-435.

Betz, O. 2003. Structure of the Tarsi in Some Stenus Species (Coleoptera, Staphylinidae): External Morphology, Ultrastructure, and Tarsal Secretion. Journal of Morphology, 255: 24-43.

Betz, O. \& Mumm, R. 2001. The predatory legs of Philonthus marginatus (Coleoptera, Staphylinidae): functional morphology and tarsal ultrastructure. Arthropod Structure and Development, 30: 77-97.

Beutel, R.G. \& Gorb, S.N. 2001. Ultrastructure of attachment specializations of hexapods (Arthropoda): evolutionary patterns inferred from a revised ordinal phylogeny. Journal of Zoological Systematics and Evolutionary Research, 39: 177-207.

Beutel, R.G. \& Gorb, S.N. 2006. A revised interpretation of the evolution of attachment structures in Hexapoda (Arthropoda), with special emphasis on Mantophasmatodea. Arthropod Systematics and Phylogeny, 64: 3-25.

Beutel, R.G. \& Gorb, S.N. 2008. Evolutionary scenarios for unusual attachment devices of Phasmatodea and Mantophasmatodea (Insecta). Systematic Entomology, 33: 501510.

Beutel, R.G. \& Kristensen, N.P. 2012. Morphology and insect systematics in the era of phylogenomics. Arthropod Structure \& Development, 41: 303-305.

Beutel, R. G., Ge, S.-Q. \& Hörnschemeyer, T. 2008. On the head morphology Tetraphalerus, the phylogeny of Archostemata and the basal branching events in Coleoptera. Cladistics, 23: 1-29.

Beutel, R.G., Friedrich, F., Hörnschemeyer, T., Pohl, H., Hünefeld, F., Beckmann, F., Meier, R., Misof, B., Whiting, M.F. \& Vilhelmsen, L. 2011. Morphological and molecular evidence converge upon a robust phylogeny of the megadiverse Holometabola. Cladistics, 27: 341-355.

Beutel, R. G., Zimmermann, D., Krauß, M., Randolf, S., \& Wipfler, B. 2010. Head morphology of Osmylus fulvicephalus (Osmylidae, Neuroptera) and its phylogenetic implications. Organisms, Diversity and Evolution, 10: 311-329.

Blanke, A., Wipfler, B., Letsch, H., Koch, M., Beckmann, F., Beutel, R. \& Misof, B. 2012. Revival of Palaeoptera-head characters support a monophyletic origin of Odonata and Ephemeroptera (Insecta). Cladistics, 28: 560-581.

Crampton, G. C. 1923. Preliminary note on the terminology applied to th,e parts of an insect's leg. Canadian Entomologist, 55: 126-132.

Dahl, F. 1884. Beiträge zur Kenntnis des Baus und der Funktion der Insektenbeine. Archiv für Naturgeschichte, 50: 146-193.

Dashman, T. 1953a. Terminology of the pretarsus. Annals of Entomological Society of America, 46: 56-62.

Dashman, T. 1953b. The unguitractor plate as a taxonomic tool in the Hemiptera. Annals of the Entomological Society of America, 46: 561-578.

Dewitz, H. 1884. Über die Fortbewegung der Tiere an senkrechten glatten Flächen vermittels eines Secretes. Archiv für die gesamte Physiologie des Menschen und der Tiere, 33: 440-481. 
Dixon, A.F.G., Croghan, P.C. \& Gowing, R.P. 1990. The mechanism by which aphids adhere to smooth surfaces. The Journal of Experimental Biology, 152: 243-253.

Dressler, C., \& Beutel, R. G. 2010. The morphology and evolution of the adult head of Adephaga (Insecta: Coleoptera). Arthropod Systematics and Phylogeny, 68: 239-287.

Fresneda, J., Grebennikov, V.V. \& Ribera, I. 2011. The phylogenetic and geographic limits of Leptodirini (Insecta: Coleoptera: Leiodidae: Cholevinae), with a description of Sciaphyes shestakovi sp. n. from the Russian Far East. Arthropod Systematics and Phylogeny, 69: 99-123.

Friedemann, K. \& Beutel, R.G. 2014. Morphology of Arolia in Auchenorrhyncha (Insecta, Hemiptera). Journal of Morphology, 275: 1217-1225.

Friedemann, K., Schneeberg, K. \& Beutel, R.G. 2014. Fly on the wall-attachment structures in lower Diptera. Systematic Entomology, 39: 460-473.

Friedemann, K., Spangenberg, R., Yoshizawa, K. \& Beutel, R.G. 2014. Evolution of attachment structures in the highly diverse Acercaria. Cladistics, 30: 170-201.

Friedrich, F., Matsumura, Y., Pohl, H., Bai, M., Hörnschemeyer, T. \& Beutel, R.G. 2014. Insect morphology in the age of phylogenomics: innovative techniques and its future role in systematics. Entomological Science, 17: 1-24.

Friedrich, F., Pohl, H., Beckmann, F. \& Beutel, R.G. 2013. The head of Merope tuber (Meropeidae) and the phylogeny of Mecoptera (Hexapoda). Arthropod Structure \& Development, 42: 69-88.

Giachino, P.M. \& Vailati, D. 1993. Revisione degli Anemadinae. Monografia di Natura Bresciana, 18: 7-314.

Giachino, P.M., Vailati, D. \& Casale, A. 1998. Major questions in the phylogeny and biogeography of Cholevidae (Coleoptera), with emphasis on the subfamily Leptodirinae. Museo Regionale di Scienze Naturali di Torino Atti, 8: 179-210.

Gladun, D. \& Gumovsky, A. 2006. The pretarsus in Chalcidoidea (Hymenoptera Parasitica): functional morphology and possible phylogenetic implications. Zoologica Scripta, 35: 607-626.

Goel, S.C. 1972. Notes on the structure of the unguitractor plate in Heteroptera (Hemiptera). Journal of Entomology, 46: 167-173.

Goel, S.C. \& Schaefer, C.W. 1970. The structure of the pulvillus and its taxonomic value in the land Heteroptera (Hemiptera). Annals of the Entomological Society of America, 63: 307-313.

Gorb, S.N. 2001. Attachment Devices of Insect Cuticle. Kluwer Academic Publishers, Dordrecht, Boston, London.

Gorb, S.N. \& Beutel, R.G. 2001. Evolution of locomotory attachment pads of hexapods. Naturwissenschaften, 88: 530-534.

Haas, F. \& Gorb, S. 2004. Evolution of locomotory attachment pads in the Dermaptera (Insecta). Arthropod Structure and Development, 33: 45-66.

Hasan, S.A. 1990. Fine structure of pretarsus in pentatomid bugs. Proceedings of the Pakistan Congress of Zoology, 10: 17-20.

Hasan, S.A. 1995. Structure and function of the pretarsus in some plant bugs (Heteroptera: Pentatomorpha). Bangladesh Journal of Zoology, 23: 35-45.

Hayes, W.P. \& Kearns, C.W. 1934. The pretarsus (articularis) in Coleoptera. Annals of Entomological Society of America, 27: 21-33.

Holway, T. R. 1935. Preliminary note on the structure of the pretarsus and its possible phylogenetic significance. Psyche, 42: 1-24.

Jeannel, R. 1911. Révision des Bathysciinae (Coléoptères, Silphides). Morphologie, distribution géographique, Systématique. Archives de Zoologie Expérimentale et Générale, 47: 1641. 
Jeannel, R. 1924. Monographie des Bathysciinae. Archives de Zoologie Expérimentale et Générale, 63: 1 - 436.

Jeannel, R. 1936. Monographie des Catopidae. Mémoires du Muséum National d'Histoire Naturelle (n.s.), 1: 1-433.

Jeannel, R. 1955. L'édéage, initiation aux recherches sur la systématique des Coléoptères. Publications du Museum National d'Histoire Naturelle, Paris, 16: 1-155.

Jiao, Y., Gorb, S. \& Scherge, M. 2000. Adhesion measured on the attachment pads of Tettigonia viridissima (Orthoptera, Insecta). The Journal of Experimental Biology, 203: $1887-1895$.

Kölsch, G. 2000. The ultrastructure of glands and the production and function of the secretion in the adhesive capture apparatus of Stenus species (Coleoptera: Staphylinidae). Canadian Journal of Zoology, 78: 465-475.

De Meijere, J.C.H. 1901. Über das letzte Glied der Beine bei den Arthropoden. Zoologische Jahrbucher, Abteilung fur Anatomie und Ontogenie der Tiere, 14: 417-476.

Levereault, P. 1935. The insect tarsus. The University of Kansas Science Bulletin, 22: 521-525.

Lis, J.A. 2010. Pretarsal structures in the family Parastrachiidae (Hemiptera: Heteroptera: Pentatomoidea). Zootaxa, 2693: 60-62.

Lis, J.A., Jastrzebska, M. \& Kocorek, A. 2002. Comparative studies on the pretarsal structures in Dinidoridae (Hemiptera: Heteroptera: Pentatomoidea). Polskie Pismo Entomologiczne, 71: 165-184.

Lis, J.A. \& Ziaja, D.J. 2010. Pretarsal structures in the family Cydnidae sensu lato (Hemiptera: Heteroptera: Pentatomoidea). Zootaxa, 2545: 23-32.

McKenna, D.D., Farrell, B.D., Caterino, M.S., Farnum, C.W., Hawks, D.C., Maddison, D.R., Seago, A.E., Short, A.E.Z., Newton, A.F. \& Thayer, M.K. 2015. Phylogeny and evolution of Staphyliniformia and Scarabaeiformia: forest litter as a stepping stone for diversification of nonphytophagous beetles. Systematic Entomology, 40: 35-60.

Nelson, C.H. 2009. Surface ultrastructure and evolution of tarsal attachment structures in Plecoptera (Arthropoda: Hexapoda). Aquatic Insects: International Journal of Freshwater Entomology, 31: 523-545.

Newton, A.F., 1998. Phylogenetic problems, current classification and generic catalog of World Leiodidae (including Cholevidae). Museo Regionale di Scienze Naturali di Torino Atti, 8, 41-177.

Newton, A.F., 2016. Leiodidae Fleming, 1821. In: Beutel, R.G. and Leschen, R.A.B., (Eds.), Handbook of Zoology, Vol. IV, Arthropoda: Insecta; Coleoptera, Morphology and Systematics (Archostemata, Adephaga, Myxophaga, Polyphaga partim), Vol. 1, 2nd ed. Walter De Gruyter, Berlin and New York, pp. 364-376.

Peck, S.B. \& Cook, J. 2002. Systematics, distributions, and bionomics of the small carrion beetles (Coleoptera: Leiodidae: Cholevinae: Cholevini) of North America. The Canadian Entomologist, 134: 723-787.

Peck, S.B. \& Cook, J. 2007. Systematics, distributions, and bionomics of the Neoeocatops gen. nov. and Nemadus of North America (Coleoptera: Leiodidae: Cholevinae: Anemadini). The Canadian Entomologist, 139, 87-117.

Peck, S.B. \& Skelley, P.E. 2001. Small carrion beetles (Coleoptera: Leiodidae: Cholevinae) from burrows of Geomys and Thomomys pocket gophers (Rodentia: Geomyidae) in the United States. Insecta Mundi 15, 139-149.

Perreau, M., 1989. De la phylogénie des Cholevidae et des familles apparentées (Coleoptera, Cholevidae). Archives des Sciences, Genève, 39: 579-590.

Peters, R.S., Meusemann, K., Petersen, M., Mayer, C., Wilbrandt, J., Ziesmann, T., Donath, A., Kjer, K.M., Aspöck, U., Aspöck, H., Aberer, A., Stamatakis, A., Friedrich, F., Hünefeld, F., Niehuis, O., Beutel, R.G. \& Misof, B. 2014. The evolutionary history of holometabolous 
insects inferred from transcriptome-based phylogeny and comprehensive morphological data. BMC Evolutionary Biology, 14:52, 1-16.

Pohl, H. \& Beutel, R.G. 2004. Fine structures of adhesive devices of Strepsiptera (Insecta). Arthropod Structure and Development, 33: 31-43.

Polilov, A. A., \& Beutel, R. G. 2009. Miniaturisation effects in larvae and adults of Mikado sp. (Coleoptera: Ptiliidae), one of the smallest free-living insects. Arthropod Structure and Development, 38: 247-270.

Randolf, S., Zimmermann, D., \& Aspöck, U. (2014). Head anatomy of adult Nevrorthus apatelios and basal splitting events in Neuroptera (Neuroptera: Nevrorthidae). Arthropod Systematics and Phylogeny, 72: 111-136.

Rombouts, J. E. 1884. Über die Fortbewegung der Fliegen an glatten Flächen. Zoologischer Anzeiger, 7: 619-623.

Schulmeister, S. 2003. Morphology and evolution of the tarsal plantulae in Hymenoptera (Insecta), focussing on the basal lineages. Zoologica Scripta, 32: 153-172.

Simmermacher G. 1884. Untersuchungen über Haftapparate an Tarsalgliedern von Insekten. Zeitschrift für wissenschaftliche Zoologie, 40: 481-556.

Spangenberg, R., Friedemann, K., Weirauch, C. \& Beutel, R.G. 2013. The head morphology of the potentially basal heteropteran lineages Enicocephalomorpha and Dipsocoromorpha (Insecta: Hemiptera: Heteroptera). Arthropod Systematics and Phylogeny, 71, 103-136.

Szymczakowski, W. 1964. Analyse systématique et zoogéographique des Catopidae (Coleoptera) de la région orientale. Acta Zoologica Cracoviensia, 9: 55-289.

Trautwein, M.D., Wiegmann, B.M., Beutel, R., Kjer, K.M. \& Yeates, D.K. 2012. Advances in Insect Phylogeny at the Dawn of the Postgenomic Era. Annual Review of Entomology, 57: 449-468.

Vasarhelyi, T. 1986. The pretarsus in Aradidae (Heteroptera). Acta Zoologica Hungarica, 32: 377-383.

Weirauch, C., 2005. Pretarsal structures in Reduviidae (Heteroptera, Insecta). Acta Zoologica, 86: $91-110$.

West, T. 1862. The foot of the fly; its structure and action: elucidated by comparison with the feet of other insects. Transactions of Linnean Society of London, 23: 393-421.

Wipfler, B., Machida, R., Müller, B. \& Beutel, R.G. 2011. On the head morphology of Grylloblattodea (Insecta) and the systematic position of the order, with a new nomenclature for the head muscles of Dicondylia. Systematic Entomology, 36: $241-$ 266.

Wipfler, B., Pohl, H., Yavorskaya, M.I. \& Beutel, R.G. 2016. A review of methods for analysing insect structures - the role of morphology in the age of phylogenomics. Current Opinion in Insect Science, 18: 60-68. 

CAPÍTULO 1 



\title{
Pretarsus and distal margin of the terminal tarsomere as an unexplored character system for higher-level classification in Cholevinae (Coleoptera, Leiodidae)
}

\author{
CAIO A N T UES-CARVALHO and PEDRO GNASPIN I \\ Departamento de Zoologia, Instituto de Biociências,Universidade de São Paulo, São Paulo, Brazil
}

\begin{abstract}
Cholevinae are well founded as a monophylum, but their internal phylogenetic relationships constitute a matter of longstanding dispute. The morphology has been the main source of information in most available phylogenetic studies on the subfamily. Most of the characters used, however, were limited to easily visible external structures and genitalia. Here we investigate the informative power of an unexplored character system for the higher-level systematics of Cholevinae: the morphology of the pretarsus and distal margin of the terminal tarsomere. We analysed and documented these structures in representatives of the five most species-rich tribes of Cholevinae (encompassing 13 subtribes) using scanning electron microscopy. We identified several diagnostic features and recognize potential synapomorphies at the tribal, subtribal and generic levels. The architecture of the median and empodial sclerites (including the empodial setae), the shape and composition of the medial projection of the distal margin of the terminal tarsomere, and the armature of the claws were considered a promising source of information for delimiting tribes and subtribes. Our data challenge the traditional view of a close proximity of Eucatopini and Ptomaphagini as well as a previously suggested synapomorphy of Leptodirini, and reinforce the monophyly of Ptomaphagini. This contribution is one of the rare comparative studies on the coleopteran pretarsus and one of very few evaluating the systematic usefulness of the distal margin of the terminal tarsomere in insects.
\end{abstract}

\begin{abstract}
Introduction
Mainly due to their attachment and locomotor function, insect tarsi and pretarsi were targets of interesting investigations involving functional morphology, ultrastructure and behaviour, among other aspects (e.g. Federle etal., 2000; Betz \& Mumm, 2001; Betz, 2002, 2003; Frantsevich \& Gorb, 2004; Eberhard et al., 2009). However, most published studies are focused only on a single or a few species. Only recently, comparative studies under a phylogenetic perspective have gained ground in the scientific literature, with an ascending number of publications evaluating the informative power of tarsal-pretarsal components for systematics and discussing their phylogenetic implications, especially for higher-level taxa - for instance, for the entire Hexapoda (Beutel \& Gorb, 2001, 2006), Acercaria (Friedemann etal., 2013), Dermaptera (Haas \&

Correspondence: Caio Antunes-Carvalho, Departamento de Zoologia, Instituto de Biociências, Universidade de São Paulo, Rua do Matão, Travessa 14, no. 101, 05508-090 São Paulo, SP, Brazil. E-mail: cantunescarvalho@gmail.com
\end{abstract}

Gorb, 2004), Diptera (Friedemann etal., 2014), Heteroptera (Weirauch, 2005), Hymenoptera (Schulmeister, 2003; Gladun \& Gumovsky, 2006; Gladun, 2008), Plecoptera (Nelson, 2009) and Strepsiptera (Pohl \& Beutel, 2004).

The beetle family Leiodidae includes around 4000 described species with very diverse feeding habits and a worldwide distribution (Newton, 1998). They occupy every continent and can be collected in habitats or microenvironments as disparate as the skin of a beaver, under the leaf litter of the Amazon rainforest, in the wide range of European caves or in a fungus in Oceania. Eighteen tribes grouped in six subfamilies are currently recognized (sensu Bouchard etal., 2011). Although there is no formal phylogenetic study published for Leiodidae, its monophyly is supported (e.g. Newton, 2005; but see Lawrence et al., 2011; Bocak et al., 2014; McKenna et al., 2015). Cholevinae is the most species-rich lineage representing around half of the entire family diversity, and includes seven tribes and 17 subtribes (Perreau, 2000; Bouchard etal., 2011). Cholevines are well 
founded as a monophylum, yet their internal phylogenetic relationships are a matter of longstanding dispute, mainly regarding the elucidation of basal dichotomies and relative position of tribes and subtribes, whose hypotheses are far from conclusive. In fact, the available phylogenetic knowledge on the subfamily is characterized by proposals either developed without cladistic methodology (Perreau, 1989; Giachino \& Vailati, 1993; Giachinoetal. , 1998; Newton, 1998, 2005) or focused on particular subgroups (Gnaspini, 1996; Fresneda et al., 2007, 2011). The suprageneric classification in Cholevinae therefore lacks a robust phylogenetic basis.

Morphology has been the core of previous phylogenetic studies. However, many of the characters used have been extracted from the field of taxonomic research, and refer to easily visible external structures and genitalia. The coverage of morphological diversity and character complexes is still substantially incomplete in Cholevinae. The pretarsus and distal margin of the terminal tarsomere are poorly studied, not only in these beetles but also in most coleopteran families. Pictorial documentations of this whole region are only available for a few species of Cholevinae (e.g. Newton, 1998; Perreau, 2000; Moldovan et al., 2007), but are clearly insufficient for a phylogenetic evaluation.

The main goal of this study was to investigate the phylogenetic information content of the pretarsus and distal margin of the terminal tarsomere for the higher-level systematics of Cholevinae. We analysed the morphology of representatives from the five most diverse tribes (comprising 13 subtribes) using scanning electron microscopy (SEM). Outgroup representatives were also examined. We describe and document for the first time the morphological diversity of the pretarsus and associated structures in cholevines, with the perspective of their application in forthcoming phylogenetic analysis. Additionally, we point out phylogenetic implications and discuss why this body region may be considered a promising character system for higher-level classification in Cholevinae.

\section{Material and methods}

\section{Taxa studied}

We analysed representatives of 40 species belonging to 13 subtribes of the five most diverse tribes of Cholevinae, and three outgroup taxa. These species, listed by name and their authorities, are provided in Table 1. The suprageneric classification of Leiodidae is based on Newton (1998), Perreau (2000) and Bouchard et al. (2011). At species level, we followed Perreau (2000, 2004). Therefore, when using references which considered Cholevinae at the family level (as Cholevidae or under the name Catopidae), we accordingly assign the proper taxonomic rank.

\section{Scanning electron microscopy}

The pretarsus of the three legs of the left side (when not available, we used the right legs) of each adult specimen were examined and documented using SEM. Dissected legs were firstly immersed in contact lens solutions for $24 \mathrm{~h}$ to clean the tegumentary structures and then dehydrated in ethanol series, air-dried or stove-dried and mounted on stubs using carbon adhesive pads. The material was sputter-coated with gold and examined in a Zeiss DSM 940 scanning electron microscope.

\section{Morphological terminology}

We mainly follow the morphological terminology from Weirauch (2005). Some additional terms are proposed here for particular structures not reported in the literature.

\section{Results}

We could observe both a general pattern of structures in Cholevinae as a whole and morphological differences among tribes, subtribes and genera. Differences were also observed between Cholevinae and representatives of Camiarinae and Leiodinae. Below we provide a description of the general morphology for cholevines, followed by particular characteristics of tribes, subtribes and genera. The main morphological differences detected among subtribes are provided in Table 2. Usually, the pretarsi and their associated structures are similar on all pairs of legs. Nevertheless, some variations were found, especially between the foreleg and the middle-hind legs.

\section{General morphology of the pretarsus and distal margin of the terminal tarsomere in Cholevinae (Fig. I)}

On the ventral distal margin of the terminal tarsomere, a pair of lateral lobes is present, connected by a median rim, which may bear a medial projection (Fig. 1A, B). If present, the medial projection varies in size and shape, in some cases providing diagnostic characters for subgroups of Cholevinae. In some taxa, the medial projection may be armed with acuminated projections (conical spines). In some groups, these spines form an oblique row which extends toward the proximal margin of the terminal tarsomere, but this condition occurs only on the forelegs (e.g. Fig. 2E, J). The oblique row extending towards the outer lateral margin of the tarsomere allows to distinguish between micrographs from right and left legs.

The lateral lobes bear a pair of setae located close to or directly inserted at the margin. The lateral seta is longer and located more laterally and distally, and it may be slightly directed sidewards. The ventrolateral seta is shorter and emerges medially on the lateral lobe, usually slightly oriented towards the ventral midline of the tarsomere (Fig. 1A, B). A pore is usually present close to the base of the lateral lobe, occasionally in the centre of a disc-shaped depression (Fig. 1A, B). In some cases, it is difficult to observe and impossible to score the presence or absence of the pore. Based on Weirauch (2005), it probably represents a campaniform sensillum, but its ultrastructure was not examined here. 


\section{C. Antunes-Carvalho and P. Gnaspini}

Table 1. List of species examined in this study.

\begin{tabular}{|c|c|c|c|}
\hline \multicolumn{2}{|c|}{ Systematic assignment } & \multirow[t]{2}{*}{ Species } & \multirow[t]{2}{*}{ Provenance } \\
\hline \multicolumn{2}{|l|}{ Cholevinae } & & \\
\hline \multirow[t]{5}{*}{ Anemadini } & Anemadina & Anemadus acicularis (Kraatz) & Basilicata, Italy \\
\hline & Eunemadina & Dissochaetus arizonensis Hatch & New Mexico, USA \\
\hline & Eunemadina & Dissochaetus vanini Gnaspini & São Paulo, Brazil \\
\hline & Eunemadina & Pseudonemadus (s.s.) cheesmani (Jeannel) & Morobe, Papua New Guinea \\
\hline & Nemadina & Nemadus sp. & Central Bohemia, Czech Republic \\
\hline \multirow[t]{9}{*}{ Cholevini } & Catopina & Catops fuliginosus Erichson & Friuli Venezia Giulia, Italy \\
\hline & Catopina & Catops subfuscus Kellner & Friuli Venezia Giulia, Italy \\
\hline & Catopina & Cholevinus fuscipes (Ménétries) & Kotayk, Armenia \\
\hline & Catopina & Rybinskiella (s.s.) magnifica (Rybiński) & Zakarpattia Oblast, Ukraine \\
\hline & Catopina & Sciodrepoides watsoni (Spence) & Tuscany, Italy \\
\hline & Cholevina & Catopsimorphus (s.s.) orientalisAubé & Peloponnese, Greece \\
\hline & Cholevina & Choleva (s.s.) agilis (Illiger) & Veneto, Italy \\
\hline & Cholevina & Choleva (s.s.) oblonga Latreille & Lombardy, Italy \\
\hline & Cholevina & Nargus (s.s.) badius (Sturm) & Liguria, Italy \\
\hline \multirow[t]{2}{*}{ Eucatopini } & & Eucatops sp. 1 & Saint Laurent du Maroni, French Guiana \\
\hline & & Eucatops sp. 2 & Madre de Dios, Peru \\
\hline \multirow[t]{13}{*}{ Leptodirini } & Anthroherponina & Anthroherpon hoermanni(Apfelbeck) & Sarajevo Canton, Bosnia and Herzegovina \\
\hline & Bathysciina & Aphaobius milleri springeriMüller & Friuli Venezia Giulia, Italy \\
\hline & Bathysciina & Orostygia doderoi doderoiMüller & Veneto, Italy \\
\hline & Bathysciina & Oryotus (s.s.) schmidtiMiller & Littoral, Slovenia \\
\hline & Bathysciina & Pretneria latitarsisMüller & Littoral, Slovenia \\
\hline & Bathysciotina & Bathysciotes khevenhuelleri tergestinusMüller & Friuli Venezia Giulia, Italy \\
\hline & Leptodirina & Astagobius angustatus laticollis Pretner & Littoral, Slovenia \\
\hline & Leptodirina & Leptodirus hochenwarti Schmidt & Friuli Venezia Giulia, Italy \\
\hline & Leptodirina & Remyella scaphoides drovenikiGiachino \& Etonti & Zlatibor, Serbia \\
\hline & Leptodirina & Speoplanes giganteus biocovensis Müller & Littoral, Slovenia \\
\hline & Pholeuina & Boldoria vailatii (Cavadini) & Lombardy, Italy \\
\hline & Pholeuina & Speonomus (Machaeroscelis) infernus(Dieck) & Midi-Pyrénées, France \\
\hline & Pholeuina & Troglocharinus (s.s.)ferreri (Reitter) & Catalonia, Spain \\
\hline \multirow[t]{11}{*}{ Ptomaphagini } & Ptomaphagina & Adelopsis leo Gnaspini & São Paulo, Brazil \\
\hline & Ptomaphagina & Adelopsis rostrataGnaspini \& Peck & Puntarenas, Costa Rica \\
\hline & Ptomaphagina & Amplexella dimorphaGnaspini & Aragua, Venezuela \\
\hline & Ptomaphagina & Parapaulipalpina sp. & Bolívar, Venezuela \\
\hline & Ptomaphagina & Paulipalpina claudicans (Szymczakowski) & Santa Catarina, Brazil \\
\hline & Ptomaphagina & Paulipalpina sp. 1 & Mérida, Venezuela \\
\hline & Ptomaphagina & Paulipalpina sp. 2 & Aragua, Venezuela \\
\hline & Ptomaphagina & Paulipalpina sp. 3 & Amazonas, Colombia \\
\hline & Ptomaphagina & Ptomaphagus (Appadelopsis)cumberlanda (Peck) & Alabama, USA \\
\hline & Ptomaphagina & Ptomaphagus (Adelops) meximontanusPeck & Querétaro, Mexico \\
\hline & Ptomaphaginina & Ptomaphaminus chapmani (Peck) & Sarawak, Malaysia \\
\hline \multicolumn{4}{|l|}{ Camiarinae } \\
\hline Agyrtodini & & Eupelates transversestrigosus (Fairmaire \& Germain) & Bío Bío, Chile \\
\hline \multicolumn{4}{|c|}{ 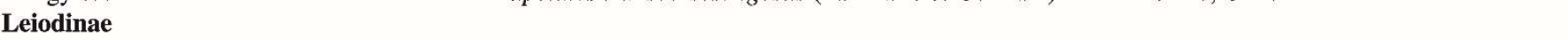 } \\
\hline Agathidiini & & Decuria sp. & Madre de Dios, Peru \\
\hline Scotocryptini & & Scotocryptus sp. & Minas Gerais, Brazil \\
\hline
\end{tabular}

The unguitractor plate is strongly sclerotized and often elongated with subparallel sides. It is bipartite in most taxa and consists of a paired row of usually oblique subdivisions devoid of setae (Fig. 1A). The distal extension of the unguitractor plate is not subdivided and ends at the base of the empodial sclerites. When the claws are retracted, the unguitractor plate is hidden behind the ventral wall of the terminal tarsomere. A membrane connects the unguitractor plate to the base of the claws, surrounding the pretarsus (Fig. 1A). Irregularly distributed cuticular protuberances (microtrichia or acanthae) may cover the surface of this membrane.
In the area between the claws, a median sclerite connects ventrally to a pair of empodial sclerites, each bearing a usually crenulated empodial seta (Fig. 1A, B). In most taxa, the empodial sclerites are fused to the median sclerite, forming a single, large, sclerotized element. The empodial sclerites are generally connected by a U-shaped median sclerotization or fused with each other. They are also frequently fused with the empodial setae. When the claws are fully extended, the empodial setae are likewise extended either anterad (as in Fig. 1A) or ventrad (i.e. perpendicularly to the main axis of the tarsus). When the claws are bent towards the tarsus, the empodial setae are turned 


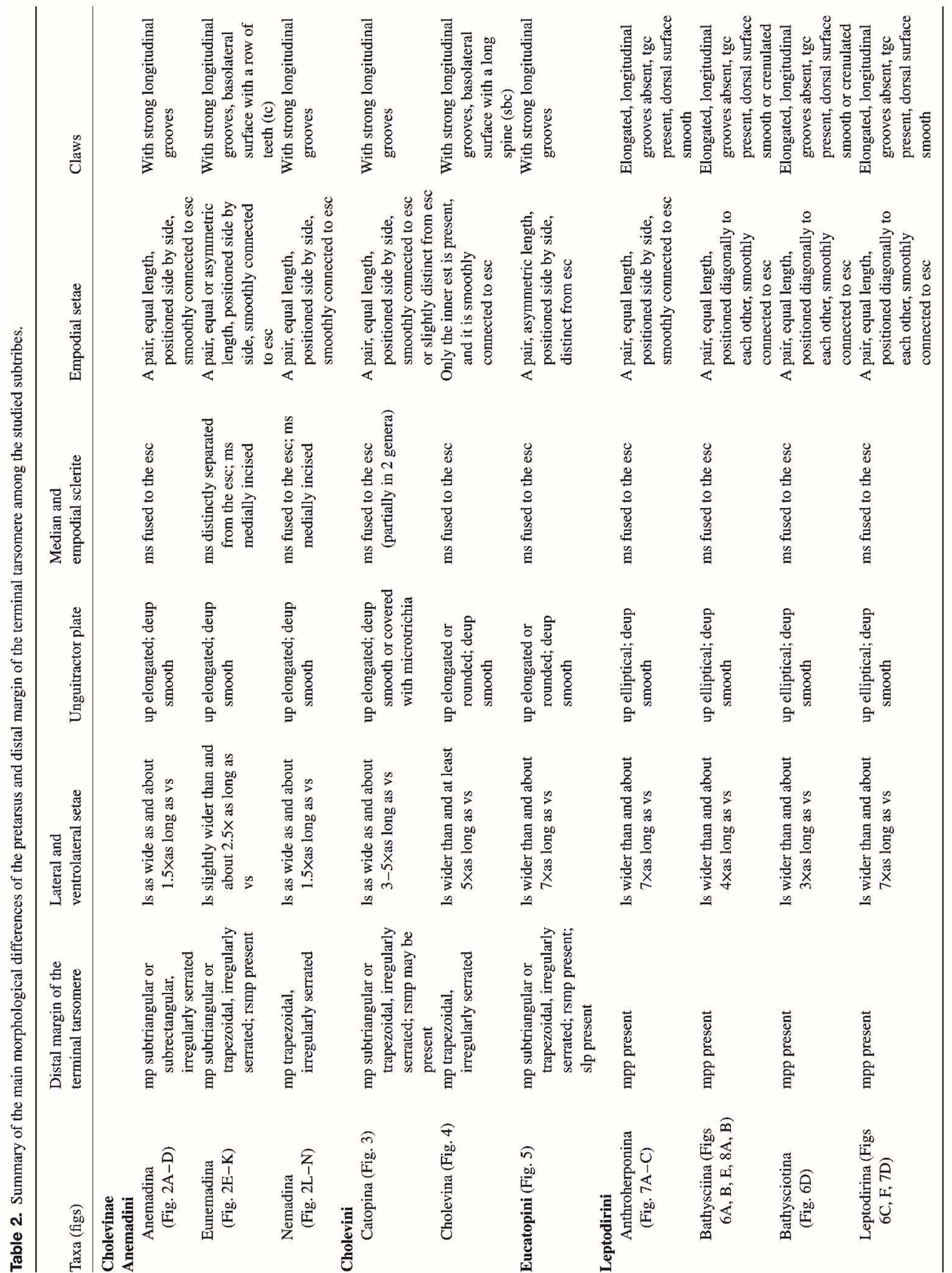

(C) 2015 The Royal Entomological Society, Systematic Entomology, 41, 392-415 


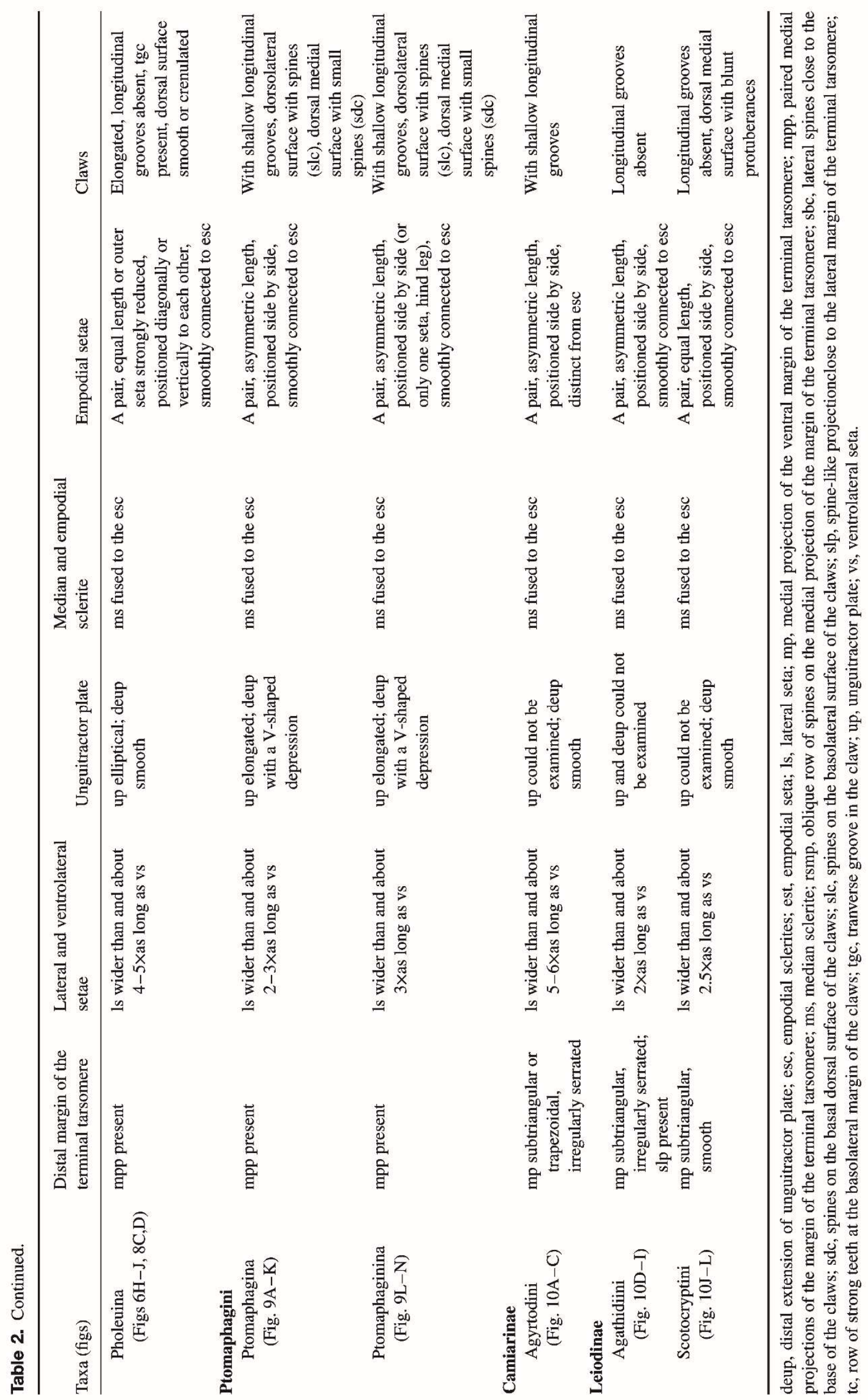

(ㄷ) 2015 The Royal Entomological Society, Systematic Entomology, 41, 392-415 

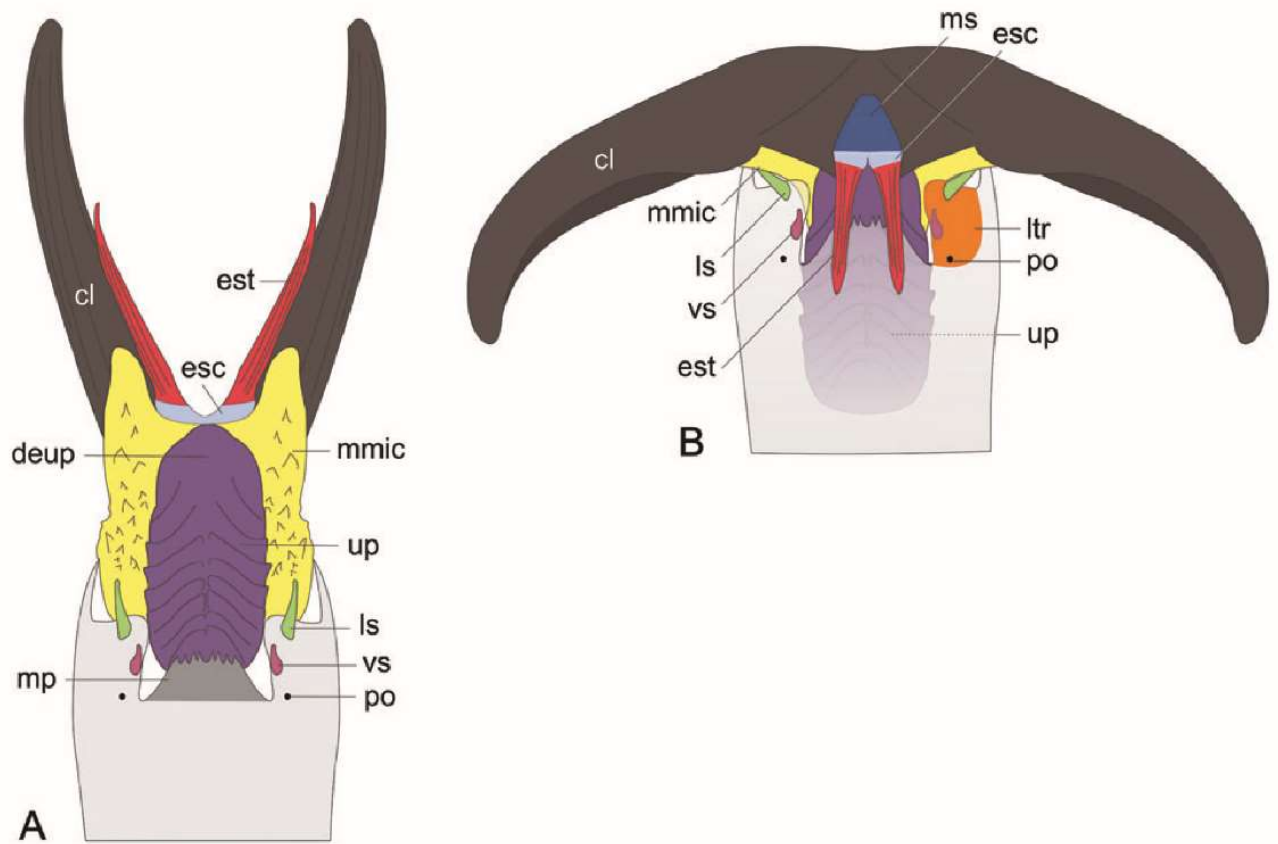

B

Fig. 1. Diagrams of the pretarsus and distal margin of the terminal tarsomere in Cholevinae. (A) Claws fully extended. (B) Claws retracted. cl, claw; deup, distal extension of unguitractor plate; esc, empodial sclerites; est, empodial seta; 1s, lateral seta; ltr, lateral lobes of the ventral margin of the terminal tarsomere; mmic, membrane with microtrichia and/or acanthae; mp, medial projection of the ventral margin of the terminal tarsomere; ms, median sclerite; po, pore on the lateral lobe; up, unguitractor plate; vs, ventrolateral seta.

towards the surface of the terminal tarsomere (as in Fig. 1B). In this case, they often embrace the medial projection of the tarsomere. The empodial setae may be distinct from each other, clearly forming a pair (as in Fig. 1), or they may be fused at the base (e.g. Fig. 6B). When a pair of empodial setae is present, they may have the same or very similar size or they can differ strongly in length; one of them can be drastically reduced to a minute structure or lack completely.

The claws are paired, mostly symmetrical, and vary in size between groups. They are usually provided with grooves extending from the base to the apex, but can be almost completely smooth. The base of the claws is frequently armed, on either the lateral and/or dorsal surfaces as an armature formed by long and thick spines, or with small and thin spines, or with a row of teeth, among other variations (see description for each subtribe for particular cases)

Some differences between the forelegs and the other two pairs may occur in the shape of the ventral margin of the terminal tarsomere and in the empodial setae. Differences in other elements of the pretarsus or even between the middle and hind legs are limited to specific taxa and are described when it is the case, as follows.

\section{Anemadini: Anemadina (Fig. 2A-D)}

The medial projection is irregularly serrated, subtriangular on the forelegs (Fig. 2A) and subrectangular (broad and short) on the other legs. The lateral seta is inserted at the posterior margin of the lateral lobe, whereas the ventrolateral seta is inserted on the ventral surface of the lateral lobe (Fig. 2B). The ventrolateral seta may have a slightly bipartite apex. No pore or depression was observed on the lateral lobe of the forelegs, but pores are present at least on the middle legs (Fig. 2A). Large microtrichia are present on the membrane around the unguitractor (Fig. 2B, C).

\section{Anemadini: Eunemadina (Fig. 2E-K)}

A diagonal row of spines is present on the ventral surface of the forelegs (Fig. 2E, J). The lateral seta is inserted close to the distal margin of the lateral lobe, whereas the ventrolateral seta is inserted on the ventral surface of the lateral lobe. A pore is present on the ventral surface of the lateral lobe (Fig. 2F, J), but only depressions can be observed on the fore- and hind legs of Dissochaetus arizonensis and on the hind legs of Pseudonemadus cheesmani.

Sparse acanthae are generally present on the membrane around the unguitractor (Fig. 2F). The median sclerite is medially incised and distinctly separated from the empodial sclerites; i.e. not fused as in most cholevines (median and empodial sclerites; Fig. 2G, K). A pair of empodial sclerites is smoothly connected to a pair of empodial setae of equal length (Fig. 2G, $\mathrm{K}$; asymmetric in Dissochaetus vanini, Fig. 2E).

Some spines emerge from the dorsal surface of the basal third of the claws in $P$. cheesmani, more pronounced on the forelegs (sgc, Fig. 2K). The basolateral margin of the claws bears a row of strong teeth (Fig. 2H, I). More teeth are present on the outer claw than on the inner one (Fig. 2E). 

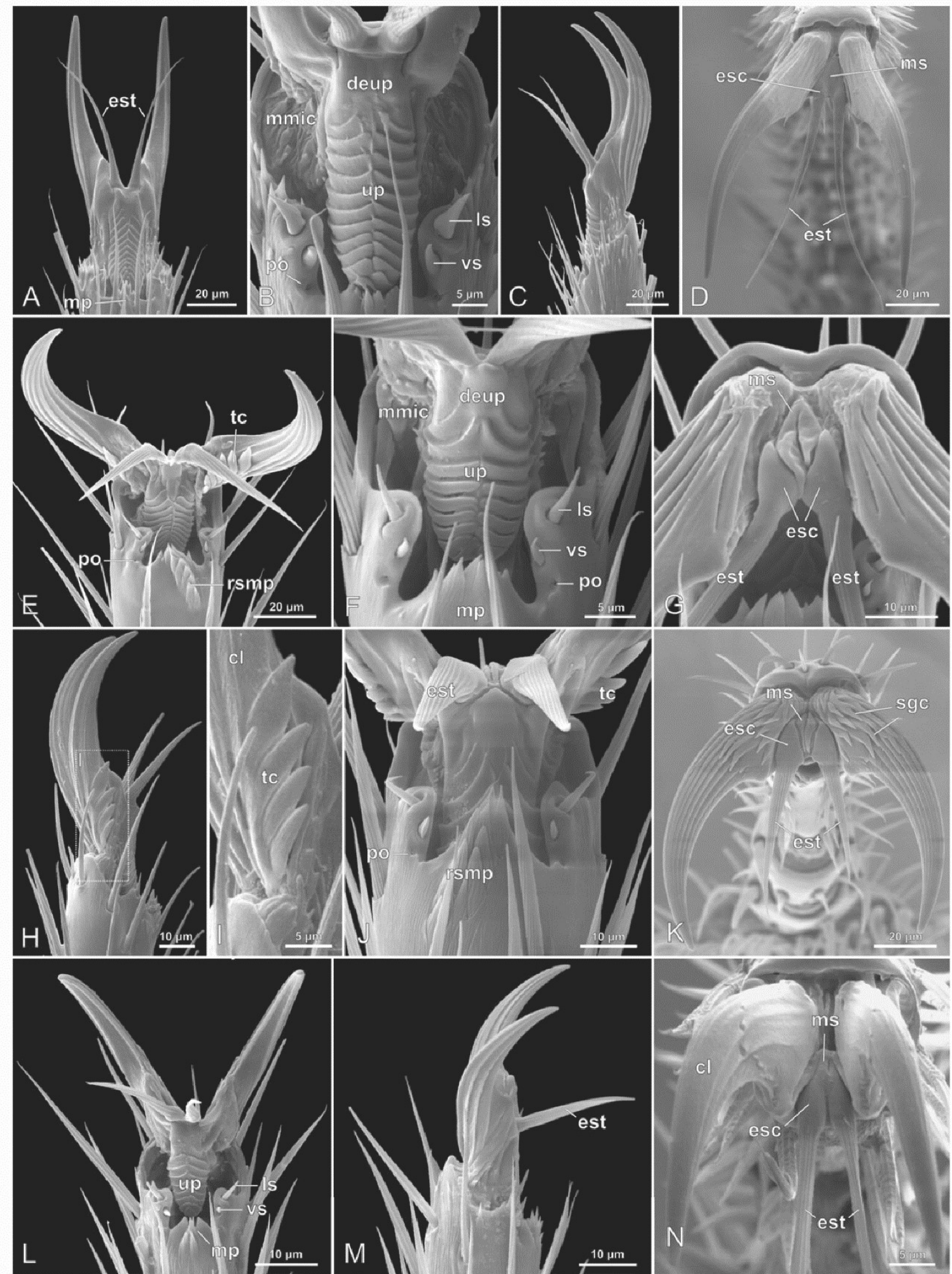

Fig. 2. Pretarsus and distal margin of the terminal tarsomere in Anemadini. (A-D) Anemadus acicularis: (A) foreleg, ventral view; (B) middle leg, ventral view; (C) foreleg, lateral view; (D) hind leg, frontal view. (E-I) Dissochaetus: (E) Dissochaetus vanini, foreleg, ventral view; (F)Dissochaetus arizonensis, middle leg, ventral view; $(\mathrm{G}) D$. vanini, middle leg, frontal view; $(\mathrm{H}, \mathrm{I})$ D. arizonensis, foreleg, lateral view. (J-K) Pseudonemadus cheesmani: $(\mathrm{J})$ foreleg, ventral view; $(\mathrm{K})$ foreleg, frontal view. $(\mathrm{L}-\mathrm{N})$ Nemadus sp.: (L) middle leg, ventral view; $(\mathrm{M})$ foreleg, lateral view; $(\mathrm{N})$ hind leg, frontal view. cl, claw; deup, distal extension of unguitractor plate; esc, empodial sclerites; est, empodial seta; 1s, lateral seta; mmic, membrane with microtrichia and/or acanthae; mp, medial projection of the ventral margin of the terminal tarsomere; ms, median sclerite; po, pore on the lateral lobe; rsmp, oblique row of spines on the medial projection of the margin of the terminal tarsomere; sgc, spines interrupting the dorsal grooves of the claws; tc, row of strong teeth at the basolateral margin of the claws; up, unguitractor plate; vs, ventrolateral seta. 
Anemadini: Nemadina (Fig. $2 L-N$ )

A row of spines is present on the ventral surface of the forelegs; some spines are visible close to the margin of the middle legs (Fig. 2L). The lateral seta is inserted close to the distal margin of the lateral lobe, whereas the ventrolateral seta is inserted on the ventral surface of the lateral lobe. Only depressions (no pores) were observed on the lateral lobes.

A few, sparse acanthae are present on the membrane around the unguitractor. The median sclerite is medially incised and the halves are fused to a pair of empodial sclerites, which smoothly connects to a pair of empodial setae of equal length (Fig. 2N). A few, sparse, small spines emerge from the surface of the basal third of the claws.

\section{Cholevini: Catopina (Fig. 3)}

The medial projection is trapezoidal in shape (Fig. 3A, O) or subtriangular on the fore- and middle legs of Catops fuliginosus and Sciodrepoides watsoni (Fig. 3E, F, I, J). On the forelegs some associated conical spines are present, which extend proximad diagonally in $C$. fuliginosus (Fig. 3E) and $S$. watsoni (Fig. 3I), but conical spines are completely lacking in Cholevinus fuscipes and Rybinskiella magnifica(Fig. 3A, N). Conical spines may also be found close to the margin in middle legs in C. fuliginosus (Fig. 3F), but not on the hind legs. The lateral seta is inserted at the ventrolateral surface of the lateral lobe, near mid-length, whereas the ventrolateral seta is medially inserted on the ventral surface of the lateral lobe (Fig. 3B, F, J, $\mathrm{O})$. The apex of the ventrolateral seta of the foreleg seems to be slightly bipartite in C. fuliginosus (Fig. 3F). In the specimen of C. fuscipes examined, one of the lateral setae of the middle leg is duplicated (Fig. 3B), possibly a mutation. The pore is usually visible and located at the base of the ventral surface of the lateral lobe (Fig. 3A, D, F, J, O). Pores were not observed on the middle and hind legs of $C$. fuscipes, but one is clearly present on one of the lateral lobes of the foreleg, indicating that the others were probably obstructed. In $R$. magnifica, a pore can be clearly seen on the middle leg and depressions are visible on the other legs. In $S$. watsoni, depressions are seen on the foreleg and pores are observed on the other legs.

In $R$. magnifica, the lobes of the unguitractor plate of the middle and hind legs are irregularly shaped. The distal extension of the unguitractor has a smooth surface, but it is covered with large microtrichia in $C$. fuscipes(Fig. 3B). The membrane around the unguitractor is covered with acanthae (varying in shape and distribution depending on the species observed; Fig. 3A, B, K, O). The median sclerite is fused to a pair of empodial sclerites, which are smoothly connected to a pair of empodial setae of equal length (Fig. 3D, G, H), but in $R$. magnifica the fusion is incomplete (Fig. 3L, M). Moreover, in this species, the empodial sclerites are partially fused to each other and both are fused with the median sclerite forming a single compact structure, not allowing the distinction of the empodial sclerites from a frontal view.

\section{Cholevini: Cholevina (Fig. 4)}

The lateral seta may be somewhat flattened (at least in Choleva) (Fig. 4F). The lateral seta is inserted at the ventrolateral surface of the lateral lobe, near mid-length, whereas the ventrolateral seta is medially inserted on the ventral surface of the lateral lobe. Pores are clearly present on the surface at the base of the lateral lobes (Fig. 4A, I, F).

The membrane around the unguitractor is almost devoid of cuticular protuberances. The median sclerite is fused to a pair of empodial sclerites from which only the inner empodial esclerite bears an empodial seta (Fig. 4B, C, F, J). The outer empodial seta is absent. As an exception, the hind leg of the specimen of Choleva oblonga has two regular empodial setae (est, Fig. 4H). Each claw bears a long (at least one-third of the length of the claw), ventrally projected spine close to the basolateral margin of the claw (Fig. 4A, D, E, G-I).

\section{Eucatopini (Fig. 5)}

The medial projection is subtriangular (forelegs) or trapezoidal (middle and hind legs), with an irregularly serrate distal margin (Fig. 5A-C). The distal margin of forelegs has some associated conical spines, which extend proximally in an oblique row (Fig. 5A, B). The lateral seta is inserted at the ventrolateral surface of the lateral lobe, close to the margin, whereas the ventrolateral seta is inserted on the ventral surface of the lateral lobe. Pores cannot be observed, but a depression is present at the base of the inner surface of the lateral lobes (Fig. 5C). A strong spine-like projection (probably a derived very thick seta) is present on each side of the tarsomere, close to the distal margin, only in the middle and hind legs (slp, Fig. 6E). A long, upward seta occurs in the forelegs at the same position (arrow, Fig. 5D).

Large microtrichia are present on the membrane around the unguitractor, especially close to the claws (Fig. 5D). The median sclerite is fused to the empodial sclerites, which are fused to each other and articulate to a pair of empodial setae (Fig. 6F, G). Most empodial setae were lacking or broken, but the outer seta seems to be shorter than the inner one.

\section{Leptodirini (Figs 6-8)}

The medial projection is emarginated medially; as a result, two distinct triangular projections are present at the ventral distal margin of the terminal tarsomere (Fig. 5A-F). In Anthroherponina, the two triangular projections are located apart from each other when compared to the other subtribes (Fig. 7A, B). In Leptodirina, except inRemyella, the two projections are slightly inclined to each other, resulting in a deeper emargination between them (Fig. 6C, F). A few minute teeth may be observed at the margin between these two triangular projections in some species. The lateral seta is inserted at the ventrolateral margin of the lateral lobe, whereas the ventrolateral seta is inserted in the internal surface of the lateral lobe. Pores or small depressions 

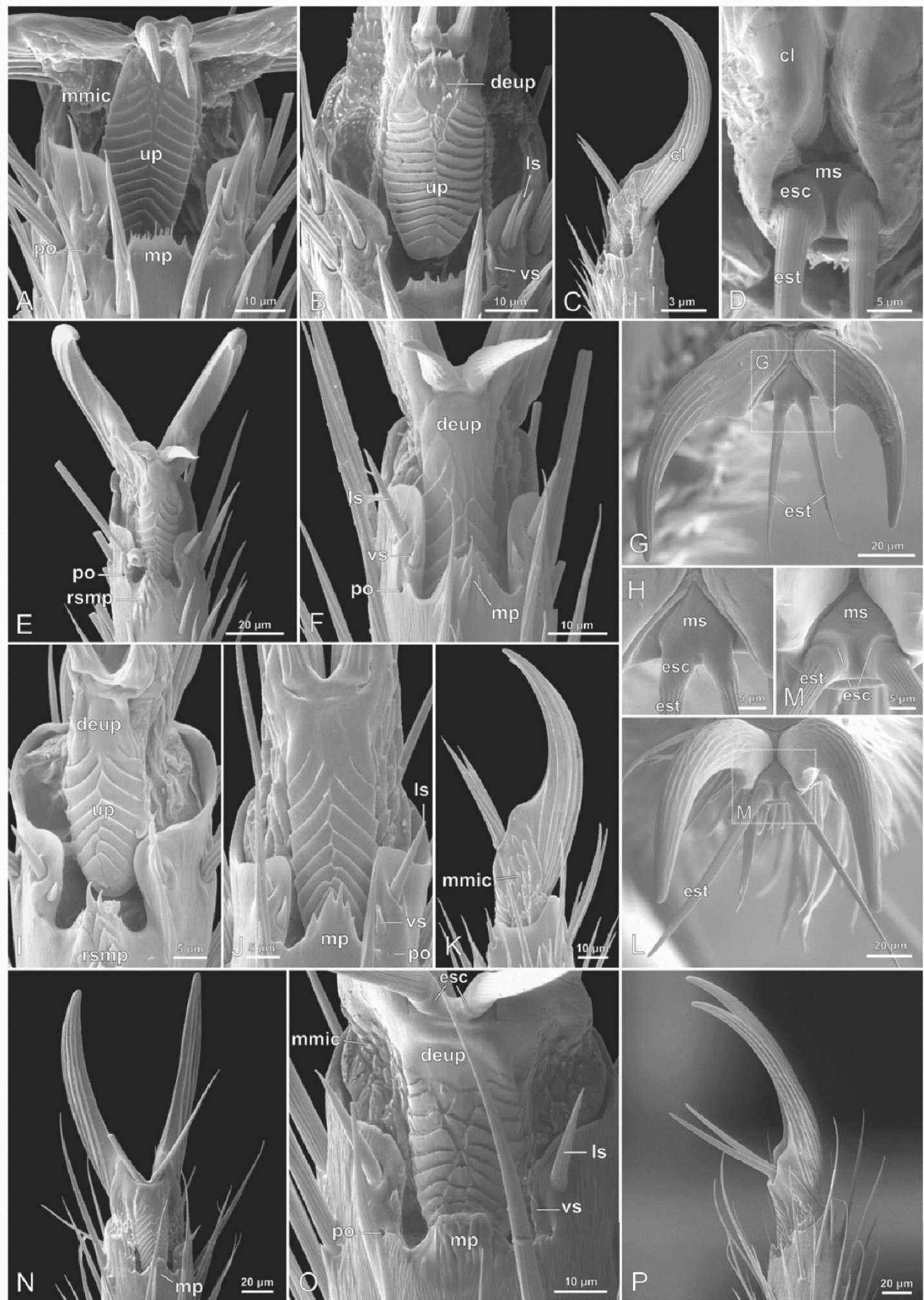

Fig. 3. Pretarsus and distal margin of the terminal tarsomere in Catopina, Cholevini. (A-D) Cholevinus fuscipes: (A) foreleg, ventral view; (B) middle leg, ventral view; (C) middle leg, lateral view; (D) middle leg, frontal view. (E-H) Catops fuliginosus: (E) foreleg, ventral view; (F) middle leg, ventral view; $(\mathrm{G}, \mathrm{H})$ hind leg, frontal view. (I-K) Sciodrepoides watsoni: (I) foreleg, ventral view; (J) middle leg, ventral view; (K) middle leg, lateral view. (L-P) Rybinskiella magnifica: (L, M) hind leg, frontal view; $(\mathrm{N})$ foreleg, ventral view; $(\mathrm{O})$ middle leg, frontal view; $(\mathrm{P})$ middle leg, lateral view. cl, claw; deup, distal extension of unguitractor plate; esc, empodial sclerites; est, empodial seta; 1s, lateral seta; mmic, membrane with microtrichia and/or acanthae; $\mathrm{mp}$, medial projection of the ventral margin of the terminal tarsomere; ms, median sclerite; po, pore on the lateral lobe; rsmp, oblique row of spines on the medial projection of the margin of the terminal tarsomere; up, unguitractor plate; vs, ventrolateral seta. 

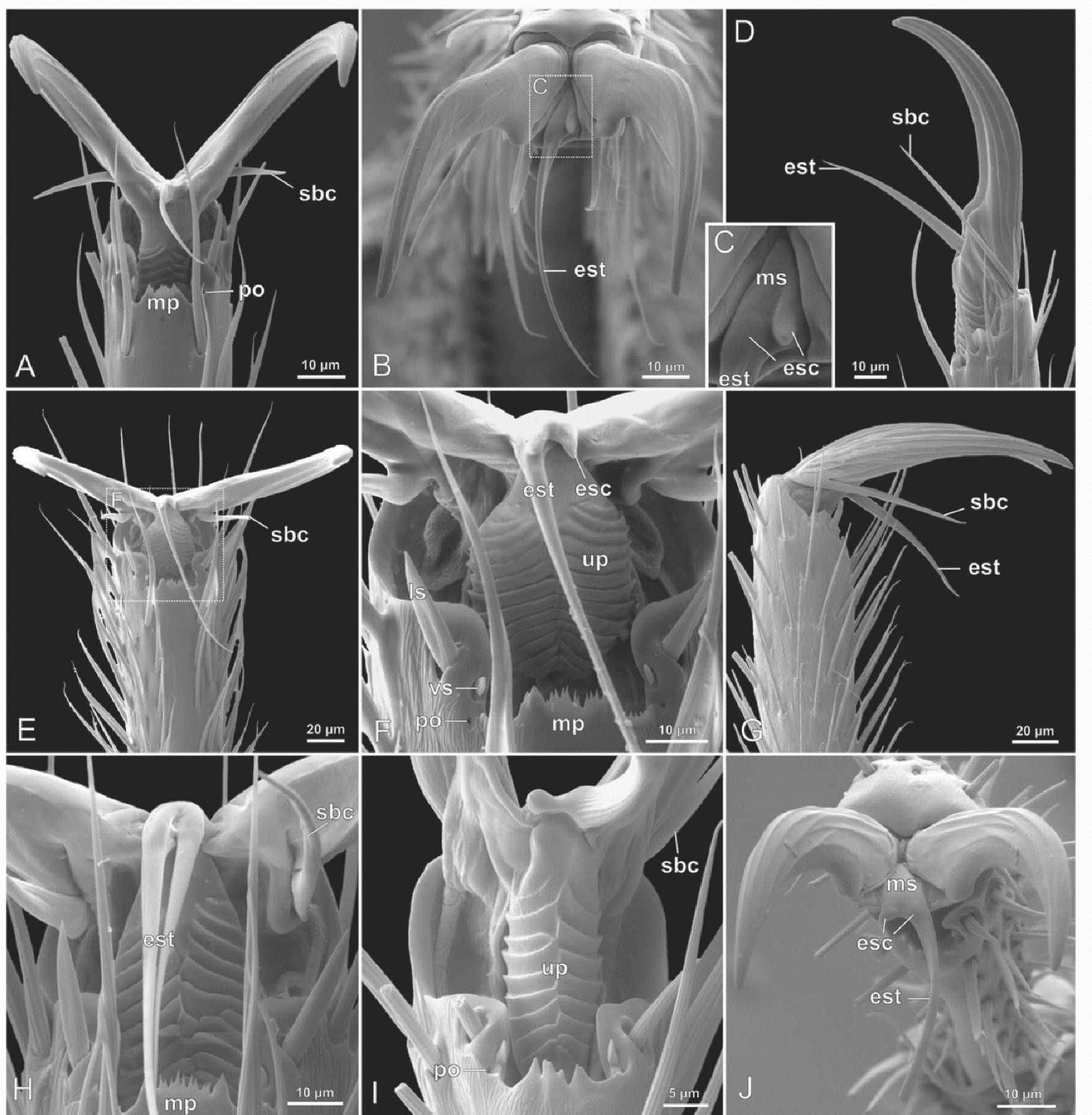

Fig. 4. Pretarsus and distal margin of the terminal tarsomere in Cholevina, Cholevini. (A-D)Catopsimorphus orientalis : (A) foreleg, ventral view; (B, C) middle leg, frontal view; (D) middle leg, lateral view. (E-H) Choleva: (E, F) Choleva oblonga, foreleg, ventral view; (G) Choleva agilis, foreleg, lateral view; (H) C. oblonga, hind leg, ventral view. (I, J) Nargus badius, middle leg: (I) ventral view; (J) frontal view. esc, empodial sclerites; est, empodial seta; ls, lateral seta; mp, medial projection of the ventral margin of the terminal tarsomere; ms, median sclerite; po, pore on the lateral lobe; sbc, lateral spines close to the base of the claws; up, unguitractor plate; vs, ventrolateral seta.

were detected at the base of the inner face of the lateral lobes of some representatives (Fig. 6B). The position of the pore makes it difficult to identify externally.

The lateral lamellae of the unguitractor usually touch each other in the midline (Fig. 6D, F), with the exception of Anthroherponina (Fig. 7B), of the Bathysciina Oryotus (Fig. 6E) and Orostygia, and of the Leptodirina Remyella
(Fig. 7D), in which an additional row of lamellae is present medially in part of the unguitractor. Cuticular protuberances were not observed on the membrane around the unguitractor in Bathysciina (Fig. 6B, E) and in the Pholeuina Boldoria, but some microtrichia are present in Bathysciotina (Fig. 6D) and in the Pholeuina Speonomus and Troglocharinus, often in rows, as well as in Leptodirina (Fig. 6F) and Anthroherponina (Fig. 7B). 

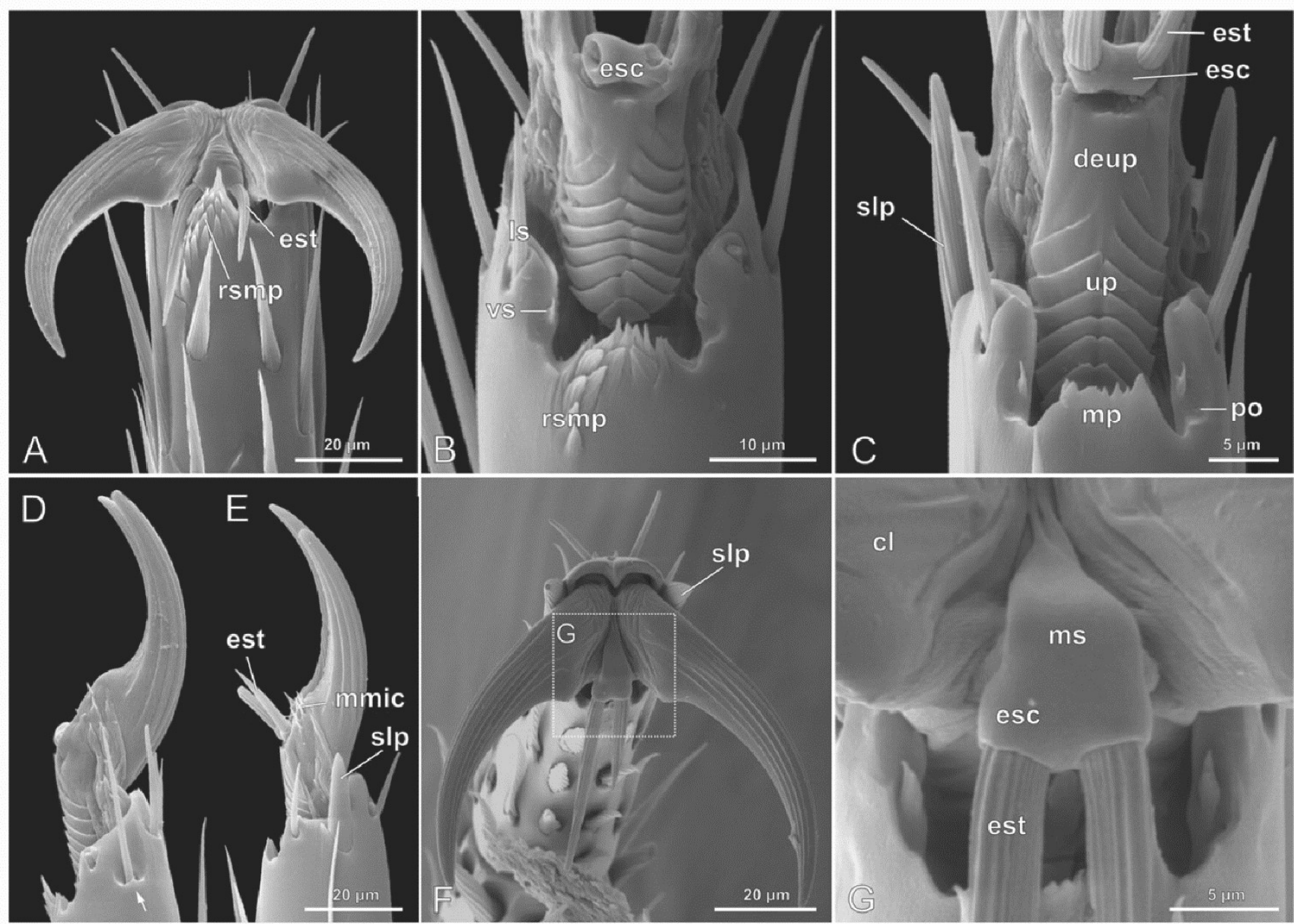

Fig. 5. Pretarsus and distal margin of the terminal tarsomere in Eucatopini. (A, F, G) Eucatops sp. 2. (B-E) Eucatops sp. 1. (A, B) Foreleg, ventral view; (C) middle leg, ventral view; (D) foreleg, lateral view (the arrow indicates a seta in the same position of the spine-like projection close to the lateral margin of the terminal tarsomere of the middle and hind legs); (E) middle leg, lateral view; (F, G) middle leg, frontal view. cl, claw; deup, distal extension of unguitractor plate; esc, empodial sclerites; est, empodial seta; ls, lateral seta; mmic, membrane with microtrichia and/or acanthae; $\mathrm{mp}$, medial projection of the ventral margin of the terminal tarsomere; ms, median sclerite; po, pore on the lateral lobe; rsmp, oblique row of spines on the medial projection of the margin of the terminal tarsomere; slp, spine-like projection close to the lateral margin of the terminal tarsomere; up, unguitractor plate; vs, ventrolateral seta.

The median sclerite is fused to the empodial sclerites. In general, the empodial sclerites cannot be recognized clearly and seem to be completely fused with each other in such a way that the two empodial setae are fused at the base (Fig. 6C). In contrast with the empodial setae of all other cholevines analysed, which are positioned side by side, the two empodial setae of Leptodirini are positioned diagonally to each other in Leptodirina (Fig. 6C, F), in the Pholeuina Boldoria (Fig. 6G), in the Bathysciina Oryotus (Fig. 6E) andPretneria, and in Bathysciotina (almost vertically in the last two groups), or vertically to each other in the BathysciinaAphaobius (Fig. 6B) and Orostygia. The proximal portion of the empodial setae has a round section and it is slightly crenulated, whereas the main part of the empodial setae is somewhat flattened. The apex of the two empodial setae often seem to touch each other (Fig. 6A), but apparently they are not fused. The AnthroherponinaAnthroherpon is an exception in which the empodial setae are positioned laterally to each other, and they are separated at the base (est, Fig. 7). The Pholeuina Speonomus and Troglocharinus are a further exception, in which only one long (inner) empodial seta, round in cross-section, can be seen, and the outer seta is strongly reduced (arrow, Fig. 6H-J).

The claws are sometimes elongate with a round apex. At about one-fifth to one-third its length from the base, a convex transversal groove is present on the dorsal surface of the claws (Fig. 8), from which the claws are somewhat flattened and have a smooth (Fig. 8A, B), or (less often) crenulated surface (Fig. 8C, D) (e.g. in the BathysciinaOrostygia, Oryotus, and Pretneria as well as in the Pholeuina Boldoria).

\section{Ptomaphagini (Fig. 9)}

The medial projection is emarginated medially. As a result, two distinct triangular projections are present at the ventral distal margin of the terminal tarsomere (Fig. 9A, C). In the genus Ptomaphagus, a third medial projection or small teeth may appear between the two typical triangular projections (arrow, Fig. 9B). The lateral seta is inserted at the ventrolateral margin 


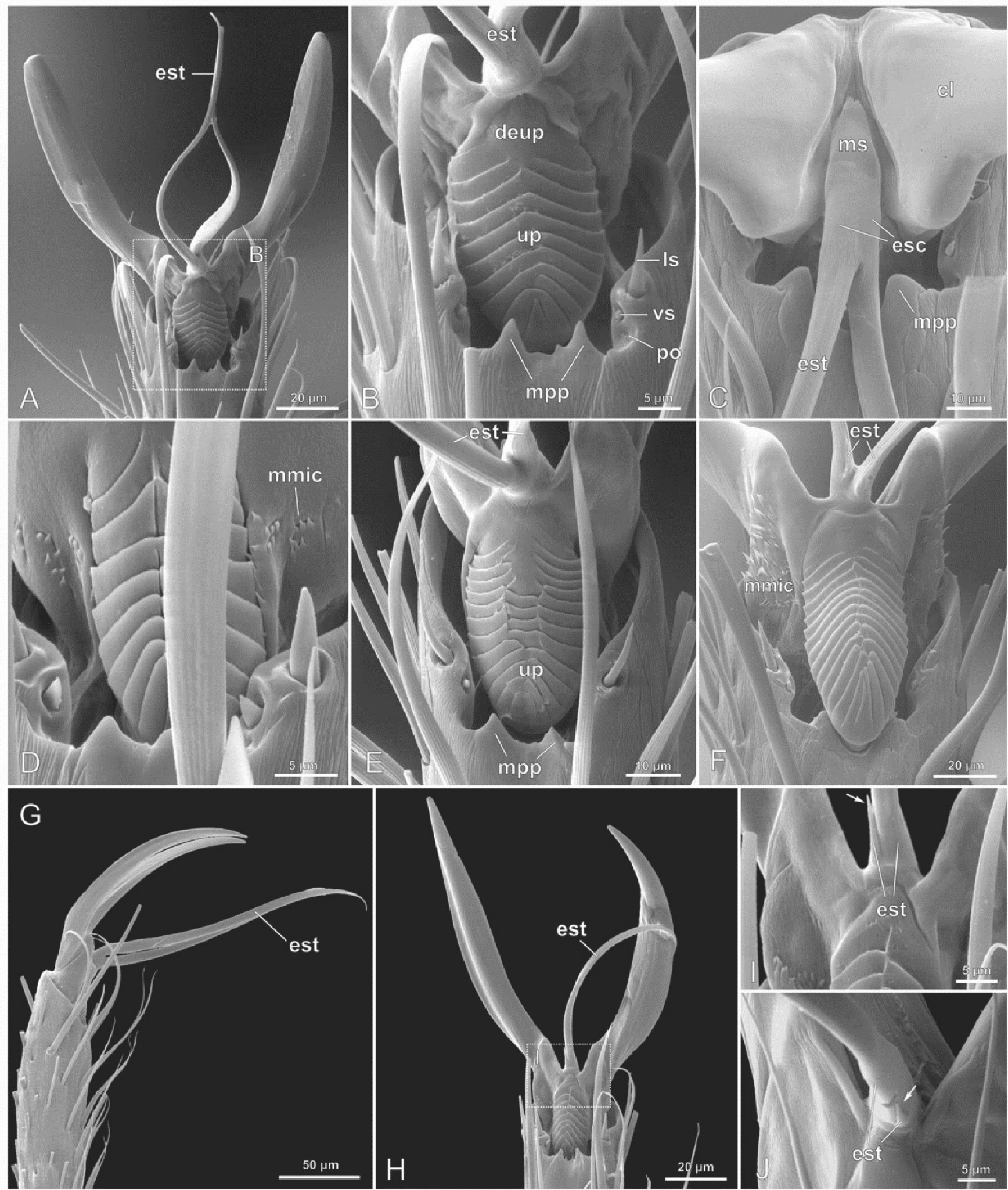

Fig. 6. Pretarsus and distal margin of the terminal tarsomere in Leptodirini. (A, B) Aphaobius milleri, middle leg, ventral view; (C) Speoplanes giganteus, hind leg, ventral view; (D)Bathysciotes khevenhuelleri, foreleg, ventral view; (E) Oryotus schmidti, hind leg, ventral view; (F) Astagobius angustatus, middle leg, ventral view; (G)Boldoria vailatii, foreleg, lateral view; (H, I) Speonomus infernus, foreleg, ventral view; (J) Troglocharinus ferreri, hind leg, ventral view. The arrow indicates the strongly reduced empodial seta (I, J). cl, claw; deup, distal extension of unguitractor plate; esc, empodial sclerites; est, empodial seta; 1s, lateral seta; mmic, membrane with microtrichia and/or acanthae; mpp, paired medial projections of the margin of the terminal tarsomere; ms, median sclerite; po, pore on the lateral lobe; up, unguitractor plate; vs, ventrolateral seta. 

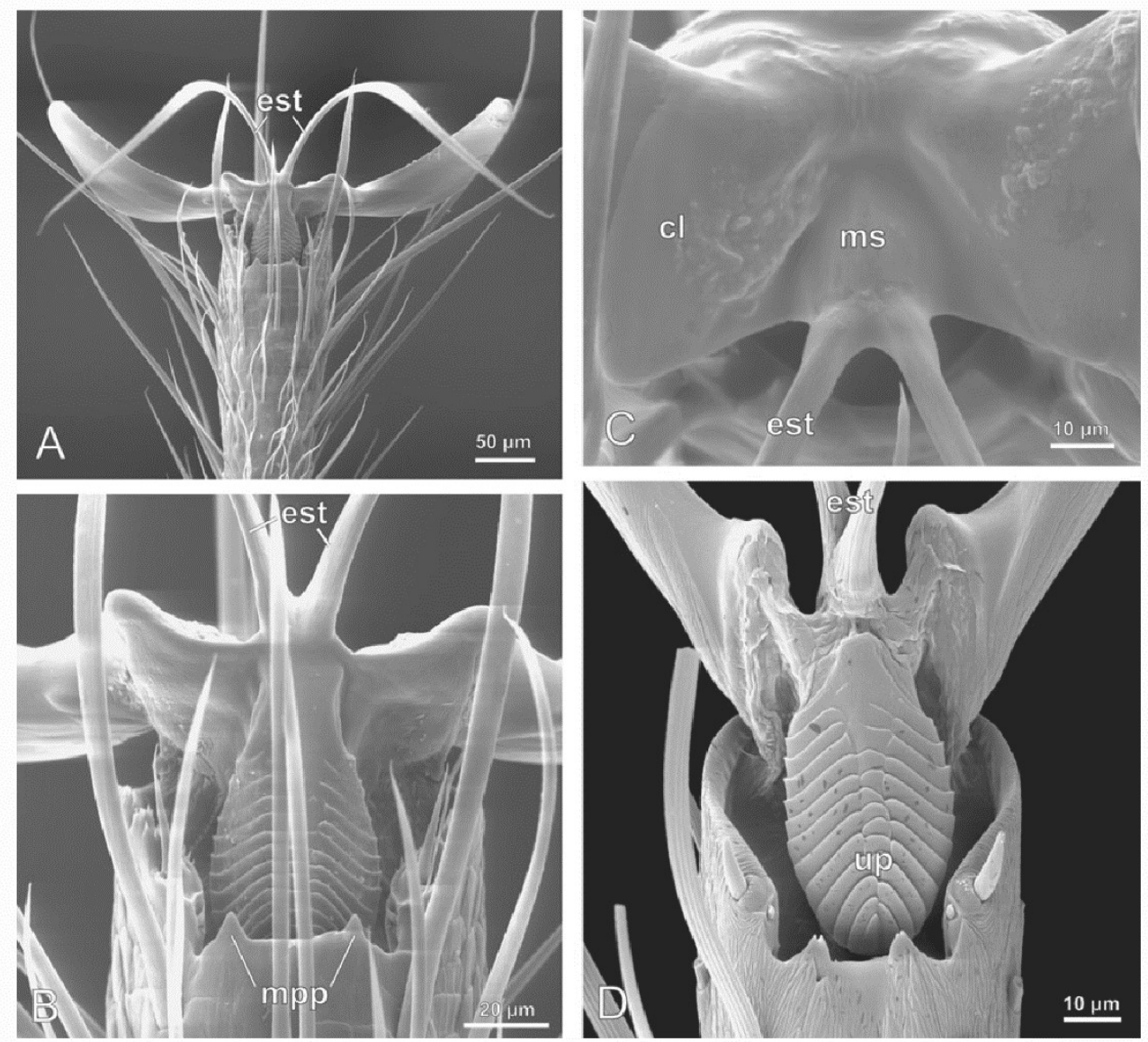

Fig. 7. Pretarsus and distal margin of the terminal tarsomere in Leptodirini. (A-C) Anthroherpon hoermanni: (A, B) foreleg, ventral view; (C) middle leg, frontal view. (D)Remyella scaphoides, middle leg, ventral view. cl, claw; est, empodial seta; mpp, paired medial projections of the margin of the terminal tarsomere; ms, median sclerite; up, unguitractor plate.

of the lateral lobe, whereas the ventrolateral seta is inserted in the internal surface of the lateral lobe (Fig. 9A-C). Pores seem to be absent, but it may be a result of the angle at which the images were taken, preventing their visualization. Nevertheless, a pore was observed in a specimen of $P$. claudicans, on only one of the lateral lobes.

The distal extension of the unguitractor plate has a medial $\mathrm{V}$-shaped depression extending to the base of the empodial sclerites (Fig. 9A, C, K). The membrane surrounding the unguitractor is covered with large microtrichia (Fig. 9A-D, K). The median sclerite is fused to a pair of empodial sclerites, which smoothly connect to the two empodial setae (Fig. 9E, F). The empodial setae are frequently asymmetrical in length (e.g. Fig. 9E), with the inner seta being somewhat longer than the outer one in the foreleg, and at least three times as long as the outer one in the middle and hind legs, except inPtomaphagus, in which the asymmetry of the setae is small (Fig. 9B). In some species (e.g.Amplexella dimorpha and Parapaulipalpina sp.) the inner empodial seta is weakly flattened, but a special case occurs inPaulipalpina and Ptomaphaminus (see later).

On the claws, a few shallow grooves extend from the base to the apex (Fig. 9D, E). Some spines protrude from the dorsolateral surface of the base of the claws (Fig. 9D, K, N).
Small spines emerge from the dorsal medial surface near the transition zone between claws (Fig. 9F, J).

The genusPaulipalpinadisplays three remarkable differences when compared with the other Ptomaphagina. On the forelegs, a long and strongly flattened medial seta is distally projecting, close to the apical margin of the dorsal surface of the terminal tarsomere (Fig. 9G, H). The middle and hind legs lack the dorsal flattened seta. However, on these legs the inner empodial setae are drastically flattened and very long (Fig. 9I, K). Additionally, the examined species share a tuft of hairs arising from the centre of the median sclerite in all legs (Fig. 9I, J).

The Ptomaphaginina here analysed (Ptomaphaminus) follow the Ptomaphagina pattern, with some differences. The membrane around the unguitractor has a few microtrichia, mainly on the distal surface close to the claws (Fig. 9M). On the fore- and middle legs, the outer empodial seta is very reduced, being about one-third of the inner seta, which is strongly flattened and elongate (reaching the claw apex) (Fig. 9L). The hind leg has only one long seta, not flattened (Fig. 9M).

\section{Outgroup representatives}

Camiarinae: Agyrtodini (Fig. 10A-C). Some conical spines are present on the medial projection of the terminal tarsomere 

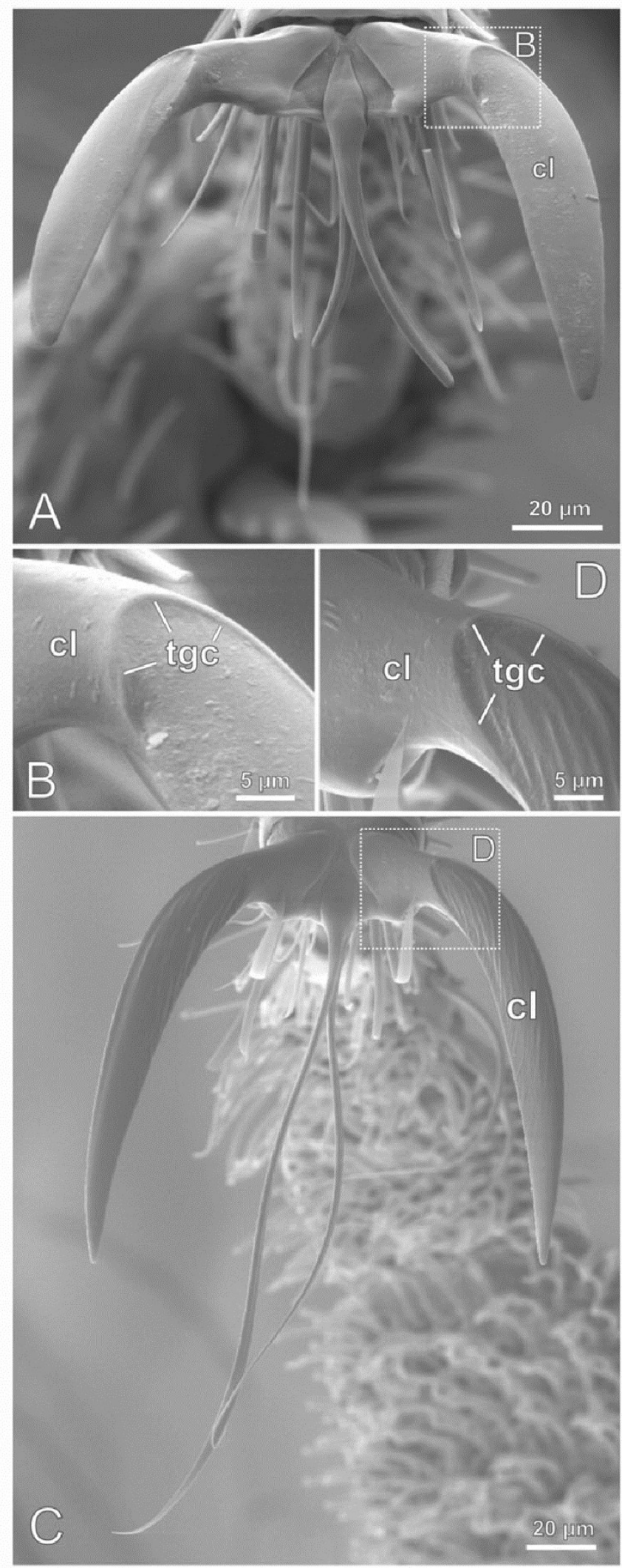

Fig. 8. Claws of Leptodirini, frontal view. (A, B)Aphaobius milleri; (C, D) Boldoria vailatii. cl, claw; tgc, transverse groove in the claw.
(Fig. 10A, B). Pores are located on the ventral surface of the base of the lateral lobes (Fig. 10B). At least in the middle legs, where the unguitractor plate is visible, it is parallel-sided and has a smooth distal extension (Fig. 10B). The membrane around the unguitractor could not be properly observed. The median sclerite is fused to the empodial sclerites, which are partially fused to each other and articulate to a pair of empodial setae (Fig. 10B, C). The hind legs were not examined.

Leiodinae: Agathidiini (Fig. 10D-I). The medial projection bears several conical spines (Fig. 10D, E). Pores could not be observed, but a depression is present on the ventral surface of the base of the lateral lobes (Fig. 10E). A long, upward seta is present on each side of the tarsomere, close to the margin, in the forelegs (arrow, Fig. 10G), whereas, in the same position, the middle and hind legs bear a strong seta (Fig. 10H, I). The unguitractor plate and the membrane around it could not be observed in the material examined. The median sclerite is fused to a pair of empodial esclerites, which smoothly connect to a pair of empodial setae of asymmetric lengths (the outer seta being shorter; Fig. 10F).

Leiodinae: Scotocryptini (Fig. 10J-L).The medial projection is subtriangular, with a smooth margin (Fig. 10J, K). Pores were not found. The unguitractor plate and the membrane around the unguitractor could not be adequately examined, but at least the membrane of the middle leg is covered with strong microtrichia (Fig. 10K). The median sclerite is fused to a pair of empodial esclerites, which smoothly connect to a pair of short curved empodial setae of equal length (Fig. 10L). The surface of the claws is devoid of grooves; blunt conical protuberances are present (Fig. 10L) close to the dorsal base. The hind legs were not examined.

\section{List of phylogenetically relevant characters}

We identified and scored 15 characters with potential phylogenetic signal based on the morphology of the pretarsus and distal margin of the terminal tarsomere of Cholevinae. Plesiomorphic character states are coded as 0 , and derived ones as 1 . It should be noted, however, that the polarity determination is preliminary until a formal cladistic analysis is conducted. The distribution of character states over the examined subtribes is given in Table 3 and mapped on to a phylogenetic hypothesis (Fig. 11):

1 Medial projection of the ventral margin of the terminal tarsomere (mp): (0) single (e.g. Figs 2F, 3J, 4F, 5C); (1) paired (mpp; e.g. Figs 6B, 7D, 9C). Two distinct triangular projections are present at the ventral margin of the terminal tarsomere in all members of Ptomaphagini and Leptodirini. In the examinedPtomaphagus and some species of leptodirines, a few small teeth may be observed at the margin between these projections. 

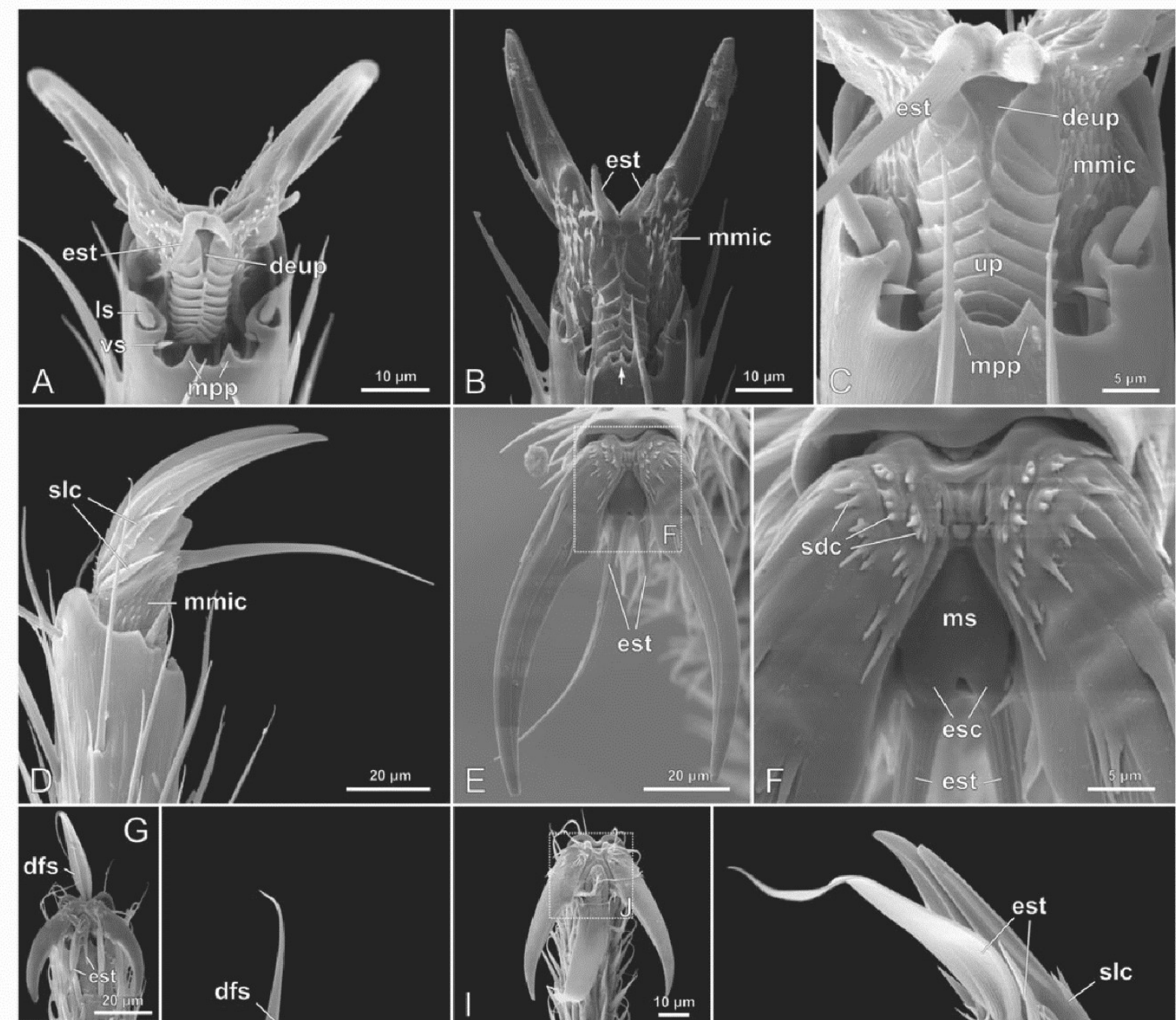

G
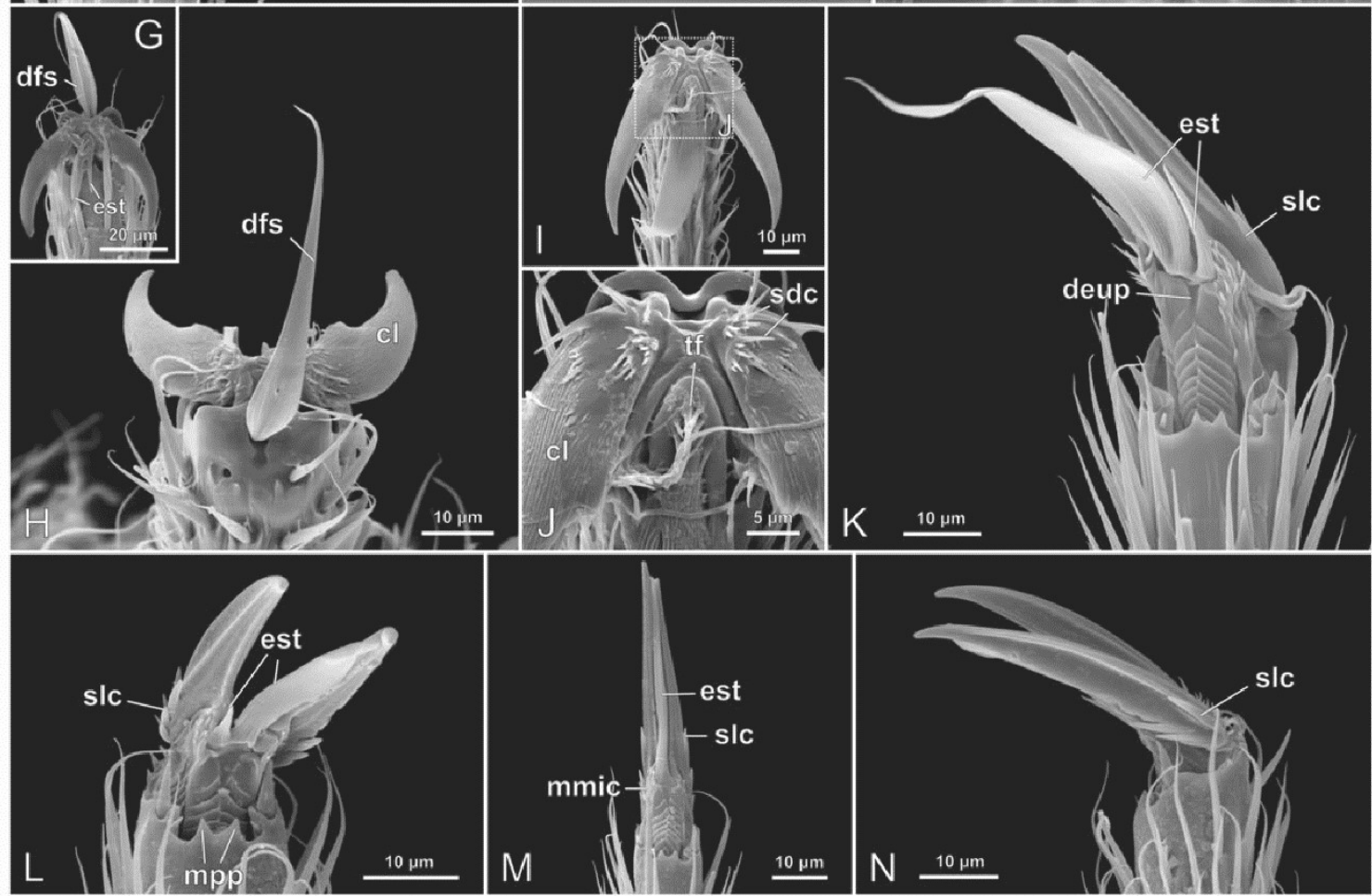

Fig. 9. Pretarsus and distal margin of the terminal tarsomere in Ptomaphagini. (A-K) Ptomaphagina; (L-N) Ptomaphaginina. (A)Adelopsis rostrata, foreleg, ventral view; (B)Ptomaphagus cumberlanda, foreleg, ventral view. (C, D) Amplexella dimorpha, foreleg; (C) ventral view; (D) lateral view. (E, F) Adelopsis leo, hind leg, frontal view. (G-K) Paulipalpina sp. 1: (G) foreleg, ventral view; (H) foreleg, dorsal view; (I, J) hind leg, frontal view; (K) hind leg, ventral view. (L-N) Ptomaphaminus chapmani: (L) foreleg, ventral view; (M) hind leg, ventral view; (N) foreleg, lateral view. cl, claw; dfs, dorsal flattened medial seta close to the apex of the terminal tarsomere; deup, distal extension of unguitractor plate; esc, empodial sclerites; est, empodial seta; $1 \mathrm{~s}$, lateral seta; mmic, membrane with microtrichia and/or acanthae; mpp, paired medial projections of the margin of the terminal tarsomere; ms, median sclerite; sdc, spines on the basal dorsal surface of the claws; slc, spines on the basolateral surface of the claws; tf, tuft of hairs on the median sclerite; up, unguitractor plate; vs, ventrolateral seta. 

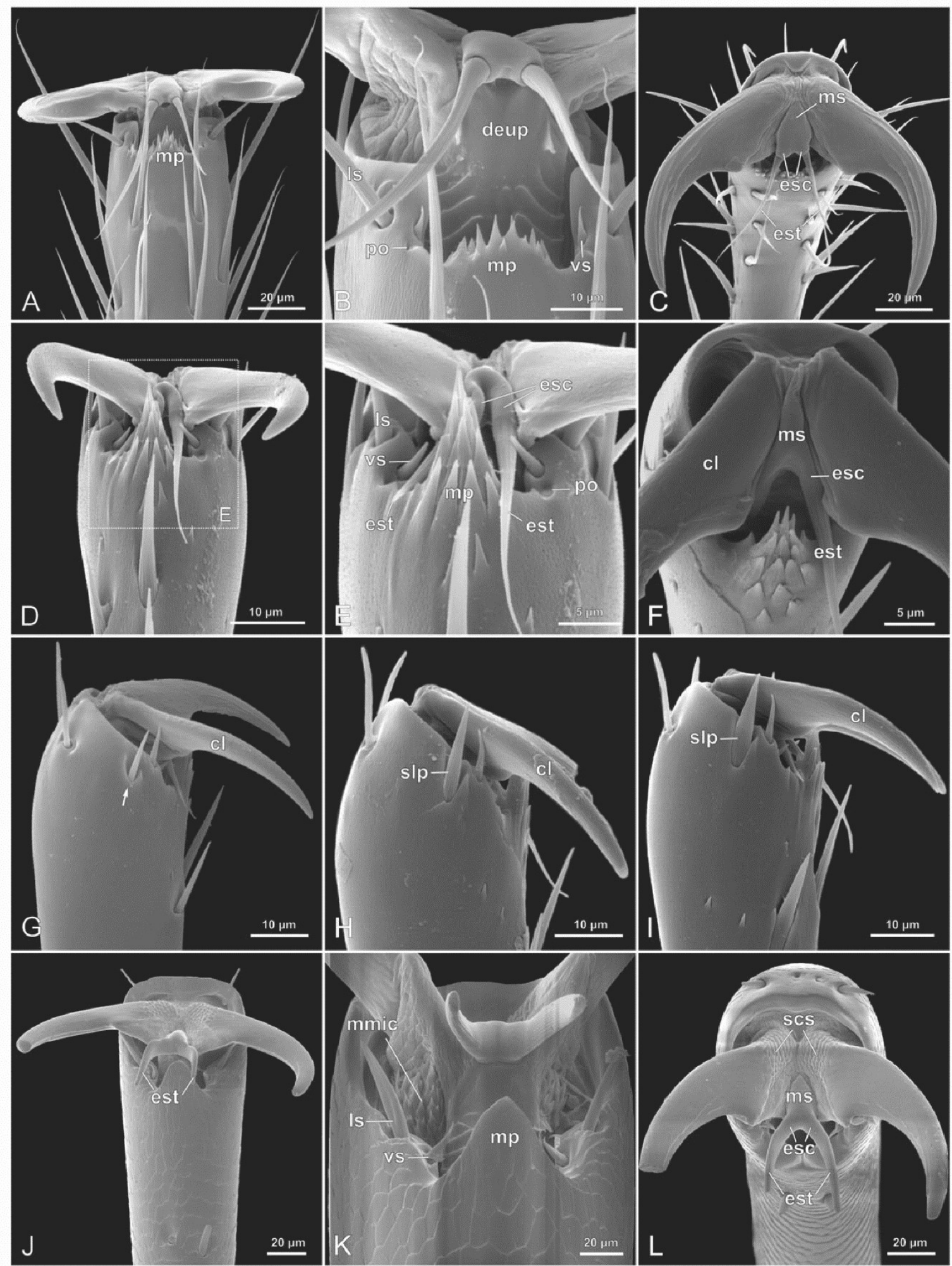

Fig. 10. Pretarsus and distal margin of the terminal tarsomere in Camiarinae (A-C) and Leiodinae (D-L). (A-C) Eupelates transversestrigosus: (A) foreleg, ventral view; (B) middle leg, ventral view; (C) foreleg, frontal view. (D-I) Decuria sp.: (D, E) foreleg, ventral view; (F) middle leg, frontal view; $(\mathrm{G}-\mathrm{I})$ lateral view of $(\mathrm{G})$ fore, $(\mathrm{H})$ middle and $(\mathrm{I})$ hind leg (the arrow indicates a seta in the same position of the slp of middle and hind legs). (J-L) Scotocryptus sp.: (J) foreleg, ventral view; (K) middle leg, ventral view; (L) middle leg, frontal view. cl, claw; deup, distal extension of unguitractor plate; esc, empodial sclerites; est, empodial seta; $1 \mathrm{~s}$, lateral seta; mmic, membrane with microtrichia and/or acanthae; mp, medial projection of the ventral margin of the terminal tarsomere; ms, median sclerite; po, pore on the lateral lobe; scs, blunt protuberances on the basal dorsal surface of the claws; slp, spine-like projection close to the lateral margin of the terminal tarsomere; vs, ventrolateral setas. 
2 Oblique row of spines on the medial projection of the terminal tarsomere of the foreleg (rsmp): (0) absent (e.g. Figs 3A, 4A, 6B, 9C); (1) present (e.g. Figs 2E, J, $3 \mathrm{E}, \mathrm{I}, 5 \mathrm{~B})$. Present in all members of Eunemadina and Eucatopini, as well as in some Catopina (Catops and Sciodrepoides).

3 Spine-like projection close to the lateral margin of the terminal tarsomere of the middle and hind legs (slp): (0) absent (e.g. Figs 3K, 4D, G, 6E); (1) present (Figs 5C, E, $\mathrm{F}, 10 \mathrm{H}, \mathrm{I})$. Eucatopini is the only cholevine taxon showing this trait. It is also present in Decuria, but not in the other examined outgroup taxa.

$4 \mathrm{~V}$-shaped depression at the distal extension of the unguitractor plate (deup): (0) absent (e.g. Figs 2B, 3O, 4I, 5C, 6B, 10B); (1) present (e.g. Fig. 9A, C, K). Present only in Ptomaphagini. In the remaining studied cholevines and in the outgroup taxa, the distal extension of the unguitractor plate is smooth (with the exception of Cholevinus, in which the presence of cuticular protuberances is probably autapomorphic; Fig. 3B).

5 Median sclerite (ms): (0) not incised medially (e.g. Figs $3 \mathrm{H}$, $\mathrm{I}, 4 \mathrm{~J}, 5 \mathrm{G}, 6 \mathrm{C}, 9 \mathrm{~F}, 10 \mathrm{C}$ ); (1) divided by a median incisure (Fig. 2G, K, N). The median sclerite is medially incised in Nemadina and even more deeply in Eunemadina, in contrast to the other taxa examined.

6 Connection between empodial sclerites (esc) and median sclerite (ms): (0) empodial sclerites fused to the median sclerite (e.g. Figs 2D, N, 3H, 4J, 5G, 6C, 9F); (1) empodial sclerites distinctly separated from the median sclerite (Fig. 2G, $\mathrm{K})$. The empodial sclerites are fused to the median sclerite in all studied taxa, with the exception of Eunemadina. The separation of the median and empodial sclerites is a potential autapomorphy of this subtribe, but a better understanding of the evolution of this character deserves better attention at the family as a whole.

7 Connection between empodial sclerites (esc) and empodial setae (est): (0) articulated (Figs 5C, G, 10B, C); (1) at least partly fused (e.g. Figs $2 \mathrm{G}, 3 \mathrm{H}, 4 \mathrm{~J}, 6 \mathrm{C}, 7 \mathrm{C}, 9 \mathrm{~F}$, $10 \mathrm{E})$. The empodial setae are fused to the empodial sclerites in all studied taxa, except in Eucatopini andEupelates . These structures appear incompletely fused in Cholevinus and Rybinskiella (coded as 1). The fusion probably occurred more than once, and outside the leiodid sampling included here (character not included in Fig. 11). A more complete sampling of Leiodidae is required for a solid interpretation.

8 Arrangement of empodial setae (est): (0) side by side (e.g. Figs 2J, 3L, 4F, 5C, 7C, 9E, F, 10L); (1) twisted (Figs 6A-C, E, F, I, J, 7D). Two empodial setae are placed diagonally or vertically relative to one another in all Old-World-Leptodirini (Leptodirini excluding Platycholeina, recognized as the sister taxon to the remaining Leptodirini by Fresneda et al., 2011), with the exception of Anthroherponina. In the examined species of this subtribe and in all other leiodid taxa included here, the two empodial setae are arranged side by side. The diagonal/vertical arrangement of the empodial setae is probably an apomorphic feature of a clade composed of Old-World-Leptodirini minus Anthroherponina, or alternatively, a feature of Old-World-Leptodirini with reversal in Anthroherponina.

9 Empodial setae (est): (0) not fused at the base (e.g. Figs 2A, 3N, 4F, 5G, 8C, 9F, 10B, L); (1) fused at the base (Fig. 6B, C, E, F, G). Correlated with the previous character, the empodial sclerites of Old-World-Leptodirini minus Anthroherponina are fused in such a way that the two empodial setae seem to be fused at the base (Fig. 6C). This condition is not found in the other Cholevinae examined here.

10 Outer empodial seta (est): (0) normal size (e.g. Figs 2A, 3A, $5 \mathrm{~A}, 6 \mathrm{~A}, 8 \mathrm{C}, 9 \mathrm{~B}$; and herein including cases of asymmetry, as in Figs 9B, K, 10A); (1) minute seta (e.g. Fig. 6H-J); (2) knob-like structure (e.g. Fig. 4B, C, F); (3) absent (e.g. Fig. 9M). A distinct reduction or loss of the outer empodial seta has probably occurred independently several times. This is indicated by different morphological patterns, suggesting a treatment as an unordered, multi-state character. In Pholeuina a minute, cryptic seta occurs in Speonomus and Troglocharinus. A small knob-like structure is present in Cholevina, possibly constituting the outer empodial sclerite. The outer empodial seta is missing in all examined specimens of this subtribe (except for a single specimen of $C$. oblonga, whose hind leg has two empodial setae, probably a mutation). InPtomaphaminus, the outer seta is lacking on the hind legs.

11 Row of strong teeth at the basolateral margin of the claw (tc): (0) absent (e.g. Figs 2C, 3C, 4D, 5D, 6G, 9D, N, 10G); (1) present (Fig. 2E, H-J). The exclusive presence in Eunemadina is potentially autapomorphic. It is herein considered a different character than the spines on the dorsolateral surface of the claws of Ptomaphagini, due to the differences in shape and position.

12 Long, lateral spines close to the base of the claws (sbc): (0) absent (e.g. Figs 2C, 3C, 5D, 6G, 9D, 10G); (1) present (Fig. 4A, D, E, G-I). A long (at least one-third of the length of the claw), ventrally projecting spine is present close to the basolateral margin of each claw of Cholevina. This is a potential autapomorphy of this subtribe.

13 Set of spines on the dorsolateral surface of the claws (slc): (0) absent (e.g. Figs 2I, M, 3K, 4G, 5D, 6G, 10G); (1) present (Fig. 9D, K-N). Some thin spines protrude from the dorsolateral surface of the base of the claws in Ptomaphagini. Please refer to the discussion in character 11. This is probably a synapomorphic trait of the tribe.

14 Set of small spines on the basal dorsal surface of the claws (sdc): (0) absent (e.g. Figs 2G, 3G, 4B, 5A, 8A, C, 10F, L); (1) present (Fig. 9F, J). Present in all members of Ptomaphagini, exclusively.

15 Transverse groove on the claws (tgc): $(0)$ absent (e.g. Figs 2D, 3G, 4B, 5A, 9E, 10C); (1) present (Fig. 8). Only in Leptodirini, a convex transversal groove is present on the dorsal surface of the claws, at about one-fifth to one-third its length from the base. 
Table 3. Characters and character states from the pretarsus and distal margin of the terminal tarsomere in the studied subtribes.

\begin{tabular}{|c|c|c|c|c|c|c|c|c|c|c|c|c|c|c|c|}
\hline \multirow[b]{2}{*}{ Taxa } & \multicolumn{15}{|c|}{ Characters } \\
\hline & 1 & 2 & 3 & 4 & 5 & 6 & 7 & 8 & 9 & 10 & 11 & 12 & 13 & 14 & 15 \\
\hline \multicolumn{16}{|l|}{ Cholevinae } \\
\hline \multicolumn{16}{|l|}{ Anemadini } \\
\hline Anemadina & 0 & 0 & 0 & 0 & 0 & 0 & 1 & 0 & 0 & 0 & 0 & 0 & 0 & 0 & 0 \\
\hline Eunemadina & 0 & 1 & 0 & 0 & 1 & 1 & 1 & 0 & 0 & 0 & 1 & 0 & 0 & 0 & 0 \\
\hline Nemadina & 0 & 0 & 0 & 0 & 1 & 0 & 1 & 0 & 0 & 0 & 0 & 0 & 0 & 0 & 0 \\
\hline \multicolumn{16}{|l|}{ Cholevini } \\
\hline Catopina & 0 & $0 \& 1$ & 0 & 0 & 0 & 0 & 1 & 0 & 0 & 0 & 0 & 0 & 0 & 0 & 0 \\
\hline Cholevina & 0 & 0 & 0 & 0 & 0 & 0 & 1 & 0 & 0 & 2 & 0 & 1 & 0 & 0 & 0 \\
\hline Eucatopini & 0 & 1 & 1 & 0 & 0 & 0 & 0 & 0 & 0 & 0 & 0 & 0 & 0 & 0 & 0 \\
\hline \multicolumn{16}{|l|}{ Leptodirini } \\
\hline Anthroherponina & 1 & 0 & 0 & 0 & 0 & 0 & 1 & 0 & 0 & 0 & 0 & 0 & 0 & 0 & 1 \\
\hline Bathysciina & 1 & 0 & 0 & 0 & 0 & 0 & 1 & 1 & 1 & 0 & 0 & 0 & 0 & 0 & 1 \\
\hline Bathysciotina & 1 & 0 & 0 & 0 & 0 & 0 & 1 & 1 & 1 & 0 & 0 & 0 & 0 & 0 & 1 \\
\hline Leptodirina & 1 & 0 & 0 & 0 & 0 & 0 & 1 & 1 & 1 & 0 & 0 & 0 & 0 & 0 & 1 \\
\hline Pholeuina & 1 & 0 & 0 & 0 & 0 & 0 & 1 & 1 & 1 & $0 \& 1$ & 0 & 0 & 0 & 0 & 1 \\
\hline \multicolumn{16}{|l|}{ Ptomaphagini } \\
\hline Ptomaphagina & 1 & 0 & 0 & 1 & 0 & 0 & 1 & 0 & 0 & 0 & 0 & 0 & 1 & 1 & 0 \\
\hline Ptomaphaginina & 1 & 0 & 0 & 1 & 0 & 0 & 1 & 0 & 0 & $0 \& 3$ & 0 & 0 & 1 & 1 & 0 \\
\hline \multicolumn{16}{|l|}{ Camiarinae } \\
\hline Agyrtodini & 0 & 0 & 0 & 0 & 0 & 0 & 0 & 0 & 0 & 0 & 0 & 0 & 0 & 0 & 0 \\
\hline \multicolumn{16}{|l|}{ Leiodinae } \\
\hline Agathidiini & 0 & 0 & 1 & 0 & 0 & 0 & 1 & 0 & 0 & 0 & 0 & 0 & 0 & 0 & 0 \\
\hline Scotocryptini & 0 & 0 & 0 & 0 & 0 & 0 & 1 & 0 & 0 & 0 & 0 & 0 & 0 & 0 & 0 \\
\hline
\end{tabular}

\section{Discussion}

This study on the pretarsus and distal margin of the terminal tarsomere in Cholevinae reveals the potential usefulness of this character system for higher-level systematics. We identified several diagnostic features and recognize potential synapomorphies at the tribal, subtribal and generic levels. The inferred phylogenetic relationships of Newton (2005), updated from Newton (1998), is used as a framework (Fig. 11) to discuss the character variation as follows. Recent molecular phylogenies provided some new insigths into the relationships within Cholevinae (e.g. Fresneda etal., 2011; Cieslak et al., 2014; McKenna et al., 2015). However, especially because their focus was not the phylogeny of Cholevinae, they did not include a sufficient sampling of the different tribes/subtribes of the subfamily, thus preventing a complete discussion concerning the subtribe relationships or the evolution of the characters treated here. Nevertheless, they are briefly compared with our findings in this discussion, whenever possible.

\section{The ground plan of the pretarsus and distal margin of the terminal tarsomere in Cholevinae}

We have not detected any potential synapormorphy for cholevines based on the structures studied here, in contrast to several probable apomorphic features at suprageneric level. Thus, the ground plan of the pretarsus and distal margin of the terminal tarsomere of Cholevinae seems to be mostly characterized by plesiomorphic traits, as discussed below.
A single medial projection on the distal margin of the terminal tarsomere is arguably a ground plan feature of Cholevinae. It is present in Anemadini, Cholevini and Eucatopini, and in all outgroup taxa [e.g. Staphylinidae (Betz, 2003); and Agyrtidae, the sister group of Leiodidae (C. Antunes-Carvalho and P. Gnaspini, personal observation)]. The paired medial projection observed in Ptomaphagini and Leptodirini is probably a shared derived state. Other likely ground plan characteristics of the terminal tarsomere are the presence of lateral setae longer than ventrolateral setae, and of a pore at the base of the lateral lobe, recognized in members of all tribes examined and in most of the outgroup taxa (pores were not detected only inScotocryptus ).

The unguitractor is elongate in most of the taxa. The smooth distal extension is probably a ground plan trait, as only Ptomaphagini and Cholevinuspossess distinct conditions. The fusion between median and empodial sclerites is presumably the plesiomorphic state in Cholevinae and occurred in all examined taxa, except Eunemadina (being a potential synapomorphy of this subtribe). It remains uncertain if the empodial sclerites are distinct from the empodial setae in the Cholevinae ground plan, or if they are fused. The empodial sclerites are articulated to the empodial setae in Eucatopini and Camiarinae, but these structures are smoothly connected (=fused) in the remaining cholevines and in the Leiodinae outgroup examined. Nevertheless, the presence of two empodial setae is arguably the ground plan feature in Cholevinae, as this condition is found in the majority of the cholevines and in the outgroup representatives analysed here, as well as in Agyrtidae and other Staphylinoidea (C. Antunes-Carvalho and P. Gnaspini, personal observation). 


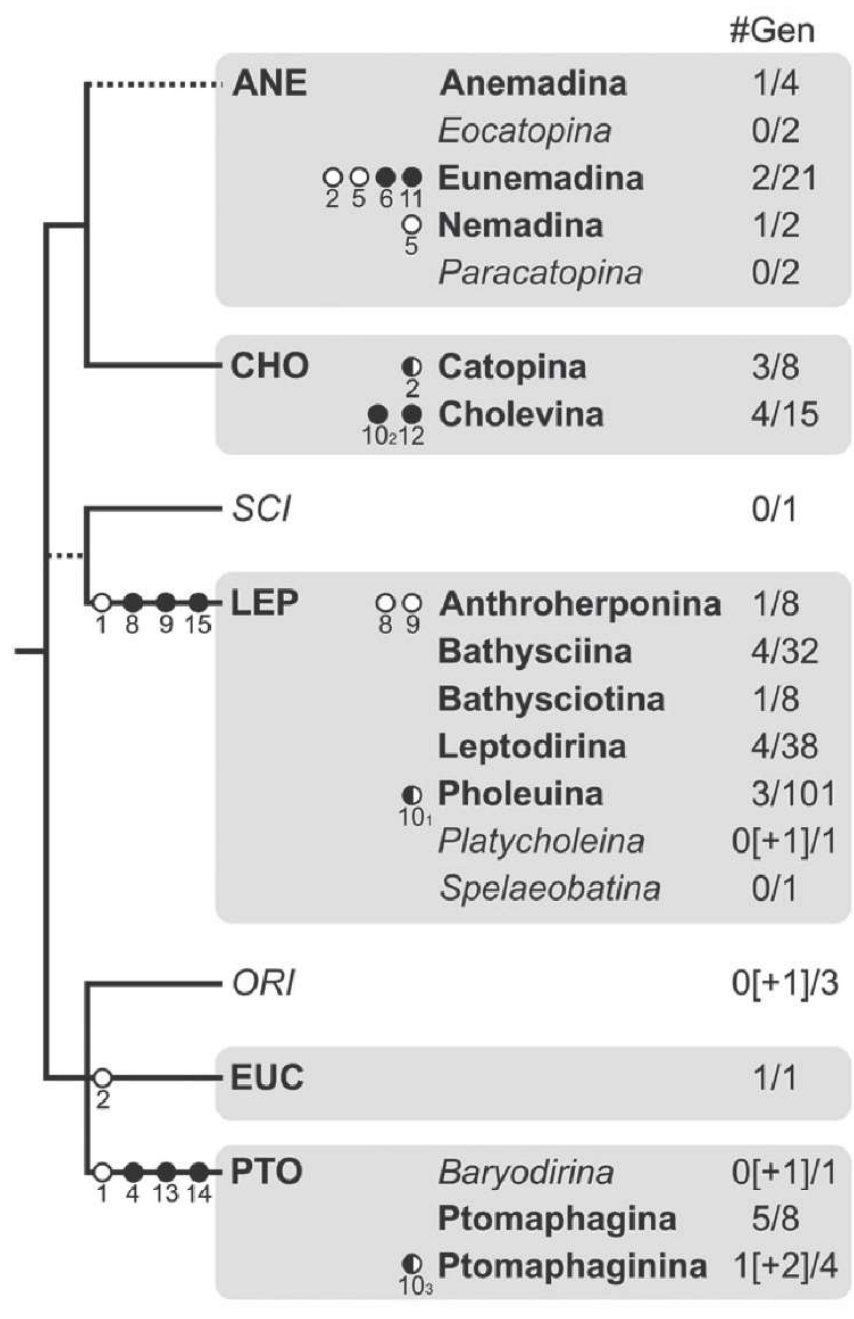

Fig. 11. Inferred phylogenetic relationships of Newton (2005, fig. 11.4.3), modified and updated from Newton (1998, fig. 12). Broken lines indicate doubtful monophyletic groups. '\#Gen' represents the number of genera examined in this study/total number of genera in each subtribe; mostly based on Perreau (2000), with some updates. Numbers between '[]' correspond to genera with images of pretarsus available in the literature. See text for description of characters. Black circles indicate potential apomorphies. Open circles indicate potential homoplasies. Partially filled circles represent polymorphic features. Taxa presented in italics were not examined in this study. ANE, Anemadini; CHO, Cholevini; EUC, Eucatopini; LEP, Leptodirini; ORI, Oritocatopini; PTO, Ptomaphagini; SCI, Sciaphyini.

The claws with longitudinal grooves and no associated spines or projections are conceivably plesiomorphic ground plan features of the subfamily. These are observed in all outgroups and most cholevines analysed, except for Cholevina, Eunemadina and Ptomaphagini. In these groups, the different spines associated with claws are probably apomorphic.

\section{Phylogenetic affinities of Eucatopini challenged}

The monotypic tribe Eucatopini was originally associated with Ptomaphagini (Jeannel, 1936), and both have been placed close to Oritocatopini in most recent taxonomic discussions (Perreau, 1989, 2000; Giachino et al., 1998; Newton, 1998). Although its internal relationships remain unresolved, the clade Oritocatopini + Eucatopini + Ptomaphagini is supported by potential synapomorphies, including the loss of the female spiculum ventrale (Perreau, 1989), a strongly developed mesoventral process (Newton, 1998), and a lacking frontoclypeal suture (Newton, 1998), among others. While representatives of Oritocatopini were not sampled in this study, we analysed several members of Ptomaphagini and no morphological affinity was detected between the latter tribe and Eucatopini. In fact, Eucatopini displays a combination of possible plesiomorphic features. Some are not found in any other Cholevinae, such as the well-defined articulation between the empodial setae and empodial sclerites (Fig. 5C, G), also observed in one of the outgroups studied here (Eupelates; Fig. 10B, C). Others, such as the presence of a single medial projection generally with irregular margin, also occur in Anemadini and Cholevini. The plesiomorphic nature of many characters of Eucatopini was previously pointed out by Newton (1998), who assumed the elongate apical maxillary palpomere and the presence of minute spiracles on abdominal segment 8 as probable plesiomorphies ofEucatops, both features shared with Oritocatopini. This scenario seems to indicate a basal position of Eucatopini in the evolution of cholevines, as already suggested by Gnaspini (1994). The strong lateral spine-like projection on the terminal tarsomere of the middle and hind legs of Eucatopini is also unique among cholevines (Fig. 5E). Yet, the presence of this trait in one of the outgroups (Decuria; Fig. 10H, I) suggests either independent evolution in distinct lineages or a shared derived character of these groups, which is unexpected. Curiously, both Eucatopini and Oritocatopini have been placed outside Cholevinae in recent molecular phylogenies (see Fresneda etal., 2011; McKenna etal., 2015). However, as is known to happen in some analyses using molecular data, the small number of taxa representatives may lead to a long branch attraction effect (e.g. see discussion in Philippe et al., 2011), in this case leading to the positioning of Eucatopini outside of Cholevinae as an artifact (because it shows several features very different from other Cholevines).

On the other hand, a diagonal row of spines on the medial projection of the forelegs is shared exclusively by Eucatopini and members of Anemadini (Eunemadina) and Cholevini (some Catopina) (Fig. 11). By comparison with the outgroups, this might be considered either a synapomorphy supporting the three tribes (with multiple reversals) or an independent acquisition of this feature. The claws of these tribes are also morphologically similar with strong grooves from the base to the apex, a distinct condition compared with the other tribes analysed here, but of uncertain phylogenetic value. Although it would be premature to assess the affinities of Eucatopini, this scenario challenges the traditional view of a close proximity of Eucatopini and Ptomaphagini, as also questioned by Gnaspini (1994). The examination of the pretarsus and the apical margin of the terminal tarsomere in Oritocatopini (as well as a broader analysis of Leiodidae as a whole) will probably shed some light on this issue. 
Morphological diversity and taxonomic usefulness within Anemadini and Cholevini

A clade composed by Anemadini + Cholevini has been supported by putative synapomorphies such as widely contiguous mesocoxal cavities, larval lacinia with a single apical tooth, and a unique larval hypopharyngeal bar (Newton, 2005). However, both tribes were recovered as polyphyletic in the phylogenetic analysis of McKenna et al. (2015). We have not detected any potential synapomorphy for this clade or for the individual tribes. Nevertheless, potential apomorphic features were identified in subordinate groups (Fig. 11).

In Nemadina and, more evidently, in Eunemadina, a medial incision divides the median sclerite into two halves (Fig. 2G, $\mathrm{K}, \mathrm{N}$ ), a condition not found in Anemadina or in any other taxa examined. Consequently, this is a plausible synapomorphy for Nemadina + Eunemadina. Additionally, members of Eunemadina possess two exclusive, potentially synapomorphic characteristics: (i) the presence of empodial sclerites distinct from the median sclerite; and (ii) a row of teeth at the basolateral margin of the claws (Figs $2 \mathrm{H}, \mathbf{I}, 11$ ). Moreover, among the Anemadini, an oblique row of spines on the medial projection of the forelegs (Fig. 2E) is shared only by species of Eunemadina, although this trait also appears in other cholevines (as discussed earlier). Based on morphological evidence from the head and genitalia, among others, this subtribe was proposed to contain a large group of mostly austral genera previously placed in Nemadina (Newton, 1998). Our data confirm Eunemadina and indicate a closer affinity of this group with Nemadina. In contrast, McKenna et al. (2015) recovered both subtribes in distantly related clades.

Cholevina+ Catopina have been recognized as a 'very homogeneous group' since the monographic work of Jeannel (1936). Newton (1998) commented that, although several authors claimed difficulties to separate these taxa from each other, they have been retained as separate subtribes, "but further study is clearly needed'. We identified two remarkable diagnostic features that easily define the studied Cholevina: (i) the presence of a long, ventrally projecting spine close to the basolateral margin of the claws (Figs 4D, G, 11); and (ii) the absence of the outer empodial seta (only a small knob-like structure is observed, probably represented by the empodial sclerite; Fig. 4C, F, J). The first one is exclusive to Cholevina and conceivably synapormorphic. The second has probably evolved independently in different lineages within Cholevinae (as will be discussed in the next sections), resulting in distinct patterns of reduction of the outer seta. Nevertheless, the remaining knob-like structure is particular to Cholevina and probably apomorphic.

Within Catopina, a substantial morphological heterogeneity of the analysed structures occurs, and we could not find any consistent diagnostic trait shared by its representatives. First, Cholevinusdiffers from the other genera by the atypical presence of microtrichia on the distal extension of the unguitractor plate of the middle and hind legs (Fig. 3B), a supposedly autapomorphic condition. Secondly, only in this genus and inRybinskiella can the insertion point of the empodial setae on the empodial sclerites be identified (Fig. 3M). Thirdly, an oblique row of spines on the medial projection of the terminal tarsomere occurs exclusively on the forelegs ofCatops andSciodrepoides (Figs 3E, I, 11), but also in Eucatopini and some Anemadini (as previously discussed). The polymorphism revealed in Catopina and the absence of any shared character seem to reflect a nonmonophyletic condition of this taxon. Further analysis on a broader taxonomic sampling is desirable.

Variation of empodial structures in Leptodirini: contradicting a previously suggested synapomorphy

Leptodirines are the most intensively studied group of the family and represent one of the largest radiations of cave-adapted coleopterans. They are also the leiodid tribe with the highest diversity, comprising around 900 described species (Fresneda et al., 2011). Their internal phylogenetic relationships have been the target of recent molecular studies (e.g. Fresnedaet al. , 2011; Cieslak etal., 2014). Fresneda etal. (2011) refuted the close relationship of Leptodirini and Sciaphyini proposed by Newton (1998), and provided evidence for the placement of Leptodirini as a sister clade of the remaining Cholevinae. Alternatively, in a broad phylogeny of Staphyliniformia and Scarabaeiformia (McKenna etal., 2015), Leptodirini was recovered in a clade with Ptomaphagini + Nemadina. The proximity between leptodirines and ptomaphagines is supported here by the presence of the paired medial projections shared exclusively by these taxa, a supposedly apomorphic feature. However, no morphological proximity between these tribes and Nemadina was identified.

In addition to the molecular evidence, Leptodirini is morphologically supported as monophyletic based on the reduction of the number of protarsomeres (from five to four) in females (Jeannel, 1936; Giachino et al., 1998; Newton, 1998). Our data show that the claws of Leptodirini are unique among Cholevinae due to the absence of longitudinal grooves and mainly the presence of an unusual transverse groove. The last feature is probably synapomorphic. Newton (1998) also added as a synapomorphy the presence of a nonarticulated empodial seta, in contrast to all other leiodids which would have two articulated setae. His statement was probably based on a SEM image of Platycholeus (Newton, 1998: Fig. 11), the only leptodirine recorded in the New World. He considered this genus to have an 'unisetose' empodium, thus differing from the other, Old World leptodirines in which this nonarticulated seta would be split and 'apparently bisetose' (Newton, 1998, p. 68 and key on pp. 111-112). This character has been adopted in subsequent phylogenetic approaches focused on Leptodirini (e.g. Fresneda et al., 2007, 2011). However, our data led us to a different interpretation.

In the leptodirines analysed, the two empodial sclerites cannot be recognized as individual structures. They are fused in such a way that the two empodial setae seem to be fused basally (Figs $6 \mathrm{C}, 11)$. In contrast to all other cholevines in which the empodial setae are positioned side by side, the two empodial setae of Leptodirini are arranged diagonally or vertically relative to one another (Fig. 6B, E, F). This condition was also found in the few taxonomic descriptions that include images of the pretarsus [e.g. the BathysciinaOrostygia(Vailati, 1998) and Blattochaeta 
(Polak \& Jalžić, 2009)]. The only exception to this pattern is the Anthroherponina studied here (Anthroherpon), whose empodial setae are aligned laterally to each other and do not seem to have the same degree of basal fusion as in other leptodirines (Fig. 7B, C). If this is interpreted as a first step toward a complete fusion (and further twisting) observed in the remaining Leptodirini, it would be in agreement with Giachino \& Etonti (1995). Based on characteristics of the aedeagus and genital segment, those authors proposed that Anthroherponina should be viewed as an early offshoot of Leptodirini.Remyella, a genus previously included in Anthroherponina, fits perfectly in the structural pattern of other subtribes of Leptodirini (Fig. 7D). This morphological similarity corroborates the exclusion ofRemyella from Anthroherponina as recently advocated by Perreau \& Pavićević (2008), who tentatively placed the genus in Leptodirina. In this context, the basal fusion of the empodial setae and the rotation of the empodial sclerites may be considered apomorphies of a possible clade formed by Old-World-Leptodirini minus Anthroherponina (adding a synapomorphy to the scenario discussed by Giachino \& Etonti, 1995), or, alternatively, synapomorphies of the Old-World-Leptodirini with reversal of each character in Anthroherponina. Since we mapped our findings onto an inferred phylogeny with no resolution among subtribes (Fig. 11), we plotted these features as synapomorphic at the Leptodirini level with reversal into Anthroherponina, even though it does not represent our agreement. It should be noted that no Anthroherponina representative was included in the molecular phylogenies involving leptodirines (see Fresneda et al., 2011; Cieslak et al., 2014), which could have provided insights for this discussion.

A distinctive feature - arguably derived from the condition outlined earlier - was found inSpeonomus and Troglocharinus, in which only one long (inner) empodial seta is visible and well developed, whereas the outer seta is highly reduced (Fig. 6I, J). These genera are included in Pholeuina, the largest subtribe of Leptodirini (Perreau, 2000) with more than 500 species, probably representing a nonmonophyletic unit. Recent phylogenetic analysis based on molecular data recovered both genera in the same clade, composed of Pyrenean leptodirines (theSpeonomus clade as in Cieslak et al., 2014). Moreover, from the literature, a single visible empodial seta was illustrated in other species of the diverse genus Speonomus (e.g. Juberthie et al., 1981; Gers, 1983, 1989; Gers \& Dupuy, 1988; Perreau, 2000: fig. 16), as well as in Trapezodirus(Fresneda et al., 2011) andPholeuon (Moldovan et al., 2007), the type genus of Pholeuina. Therefore, the (seemingly) single empodial seta (with a cryptic second seta) may be a potential synapomorphy restricted to a subgroup within Pholeuina (whose limits would be defined with further studies). This seems to be an additional, independent case of reduction of empodial setae within Cholevinae, morphologically different from that reported in Cholevina.

The typical pattern of two empodial setae found in most leptodirines have been considered as a single, split seta and as synapomorphic (see, e.g., Fresneda et al., 2007, character 5). However, considering that (i) the predominant morphological condition of Leptodirini may have been plausibly acquired by a fusion of the empodial sclerites (and also of the base of empodial setae) from the original state with two empodial setae, and that (ii) a second cryptic empodial setae can still be seen in the leptodirines with a single visible seta, we disagree with the interpretation that a single empodial seta would be synapomorphic for Leptodirini as a whole. Instead of an evolutionary scenario with two empodial setae first reduced to a single one, and afterwards split into two, we suggest a transformation series from two long empodial setae to a single one, resulting from a drastic reduction of the outer seta.

Platycholeus, also with a single visible empodial seta (see Newton, 1998: Fig. 11), is the single genus of Platycholeina. It is also the single representative of Leptodirini in the New World, still with well-developed eyes and hindwings, contrary to the mostly cave-adapted European leptodirines (Newton, 1998; Fresneda etal., 2011). According to Newton (1998), Platycholeus has virtually all derived characters that have been recognized for Leptodirini, and is probably a relict basal member of this tribe, leading to his interpretation of a single empodial seta as the ground plan condition in Leptodirini. Phylogenetic studies based on molecular data recently corroborate the sister-group relationship of Platycholeuswith the remaining, Old-World-Leptodirini (Fresneda et al., 2011; Cieslak et al., 2014). Therefore, if the presence of two empodial setae is the plesiomorphic state in Leptodirini (as indicated by our results), then the strong reduction of the outer empodial seta occurred at least twice in the evolution of the tribe (i.e. inPlatycholeus and within Pholeuina). This topic deserves further investigation, including a new analysis of Platycholeus .

\section{Support for the monophyly of Ptomaphagini and implications for internal relationships}

Ptomaphagini has been treated as a monophyletic group by most experts, but often without explicit reference to a convincing synapomorphy. Its monophyly was suggested in two previous phylogenetic studies, but both were based on a poor sampling of ingroup (Fresneda et al., 2011) or outgroup taxa (Gnaspini, 1996). We described here, for the first time, two separate sets of spines located on the claws of all studied representatives of Ptomaphagini (Fig. 9D-F). Additionally we also identified an atypical V-shaped depression in the distal extension of the unguitractor plate (Fig. 9A, C). These features are probably synapomorphic and support the monophyly of Ptomaphagini (Fig. 11). Further, seemingly exclusive morphological elements, but with uncertain phylogenetic significance, are the claws with a few longitudinal grooves and the empodial setae of unequal length.

Three subtribes are recognized in Ptomaphagini: Baryodirina, Ptomaphagina and Ptomaphaginina. A strongly flattened empodial seta (e.g. Fig. 9K) occurs at least on one pair of legs of representatives of each subtribe - i.e. Baryodirus (Perreau, 2000), Paulipalpina and Ptomaphaminus - probably constituting an independent acquisition. Behavioural data for Ptomaphagini are almost nonexistent, even for most Cholevinae, which makes such modified setae an intriguing topic. Curiously, a similar flattened seta occurs dorsally close to the apical margin of the terminal protarsomere inPaulipalpina (Fig. 9G, H). Species of 
this genus also share an exclusive tuft of hairs located at the centre of the median sclerite (Fig. 9J). In recent years, new species have been described inPaulipalpina(Salgado, 2010, 2013a,b), but the characteristics revelead here, especially the last two, have never been reported in the literature and were not found in any other cholevine taxa. These are probable autapomorphic features of this genus. Although morphologically well defined, Paulipalpinawas placed in a trichotomy withParapaulipalpina and Ptomaphagusin the only available phylogeny of Ptomaphagini (Gnaspini, 1996). The elements of the pretarsus will probably provide new insights into the internal relationships of this tribe in future phylogenetic analysis.

\section{Towards a phylogeny of Cholevinae}

The current picture of the internal phylogenetic relationships in Cholevinae is dramatically obscure. Much of what we know about these beetles derives from alpha taxonomy, with a large amount of information restricted to male genitalia and simple external morphological characters. Most phylogenetic discussions on suprageneric relationships in Cholevinae are based primarily on reinterpretations of these characters and the identification of the apomorphic state in order to improve the taxonomic scheme of the subfamily (e.g. Jeannel, 1936; Perreau, 1989; Giachino \& Vailati, 1993; Giachino et al., 1998; Newton, 1998, 2005). These studies have generated contrasting results and, as a consequence, alternative classifications. All of them have in common the lack of a formal cladistic character evaluation. Recently, molecular data have been incorporated into a phylogenetic approach and tentatively shed some light on the internal relationships in Cholevinae (Fresneda et al., 2011). Yet, it should be viewed with reservation as it was explicitly not designed for addressing internal relationships throughout the subfamily, and thus did not include adequate sampling of each tribe/subtribe. Therefore, the Cholevinae classification is still premature and not supported by a robust phylogenetic framework.

The morphological descriptions and documentation presented here aim to provide the foundation for systematic interpretation of components of the pretarsus and distal margin of the terminal tarsomere. The characters extracted from this body region should be subjected to testing in upcoming higher-level phylogenetic analysis integrating additional data sets. In the few published phylogenies involving subgroups of Cholevinae, only a single morphological character (whose validity was questioned here) has been extracted from the pretarsus (e.g. Fresneda et al., 2011, character 14). This scenario reflects, at least in part, the difficulty of documenting this character system accurately. The morphological elements can be easily hidden when the claws are retracted, and the usual presence of adhered particles is an additional inconvenience. It makes the preparation of the material a time-consuming process. Furthermore, morphological investigations under light microscopy are clearly limited by the small size of the structural details.

Our data corroborate some previously established hypothesis, but also challenge some traditional concepts. Although we analysed data from almost all subtribes recognized in Cholevinae, it was not our goal to solve all the discussions concerning the relationships among these subtribes. Nevertheless, we understand that our findings are relevant from a taxonomic point of view, as they clearly show that the structures of the pretarsus and distal margin of the terminal tarsomere are useful tools to recognize taxa at tribal, subtribal and generic levels. This is especially important in groups such as the Ptomaphagini, in which external characters are very conservative, rendering it difficult to recognize or characterize most genera unambiguously. This may also be the case of Leptodirini, the largest tribe of Cholevinae with a still controversial subtribal scheme. In fact, for both tribes, we have found diagnostic characters concerning the pretarsus and associated structures, adding to the better recognition of these groups (Fig. 11).

This contribution is one of the rare comparative studies on the coleopteran pretarsus and one of very few evaluating the systematic usefulness of the distal margin of the terminal tarsomere in insects. From our data, three morphological elements seem to add important information to the definition of tribes and subtribes in Cholevinae: the architecture of the median and empodial sclerites (including the empodial setae), the shape and composition of the medial projection of the distal margin of the terminal tarsomere, and the armature of the claws. Ongoing efforts toward integrating these morphological characters with additional data sets in order to conduct a formal phylogenetic analysis of the subfamily are anticipated to reach a more phylogenetically supported stable classification for Cholevinae.

\section{Acknowledgements}

We thank the following researchers for the loan/donation of the studied material: Andrea Colla (Museo Cívico di Scienze Naturali, Trieste, Italy), Cristiano Lopes Andrade (Universidade Federal de Viçosa, Viçosa, Brazil), Jan Růžička (Czech University of Life Sciences, Praha, Czech Republic), Richard Leschen (Landcare Research, Auckland, New Zealand), Stefano Zoia (Museo Civico di Storia Naturale di Milano, Milano, Italy) and Stewart Peck (Carleton University, Ottawa, Canada). Richard Leschen read this manuscript prior to submission and provided helpful comments. This study was supported by grants from FAPESP (Fundação de Amparo à Pesquisa do Estado de São Paulo, Brazil) no. 2012/19002-0 (to C.A.C.) and no. 2013/06314-7 (to P.G.). We thank Dr Alberto A.G.F.C. Ribeiro and Márcio V. Cruz for access to and help in the use of the electron microscopy facilities from the Electronic Microscopic Laboratory of IBUSP. We are deeply grateful to the reviewers and the editor for valuable suggestions that significantly improved the manuscript. The authors declare that they have no conflict of interest.

\section{References}

Betz, O. (2002) Performance and adaptive value of tarsal morphology in rove beetles of the genus Stenus (Coleoptera, Staphylinidae). Journal of Experimental Biology, 205, 1097-1113. 
Betz, O. (2003) Structure of the tarsi in some Stenus species (Coleoptera Staphylinidae): external morphology, ultrastructure, and tarsal secretion. Journal of Morphology, 255, 24-43. DOI: 10.1002/jmor.10044.

Betz, O. \& Mumm, R. (2001) The predatory legs of Philonthus marginatus (Coleoptera, Staphylinidae): functional morphology and tarsal ultrastructure. Arthropod Structure \& Development, 30, 77-97. DOI: $10.1016 / \mathrm{S} 1467-8039(01) 00029-9$.

Beutel, R.G. \& Gorb, S.N. (2001) Ultrastructure of attachment specializations of hexapods (Arthropoda): evolutionary patterns inferred from a revised ordinal phylogeny. Journal of Zoological Systematics and Evolutionary Research, 39, 177-207. DOI: $10.1046 / \mathrm{j} .1439-0469.2001 .00155 . x$.

Beutel, R.G. \& Gorb, S.N. (2006) A revised interpretation of the evolution of attachment structures in Hexapoda with special emphasis on Mantophasmatodea. Arthropod Systematics \& Phylogeny, 64, $3-25$.

Bocak, L., Barton, C., Crampton-Platt, A., Chesters, D., Ahrens, D. \& Vogler, A.P. (2014) Building the Coleoptera tree-of-life for $>8000$ species: composition of public DNA data and fit with Linnaean classification. Systematic Entomology, 39, 97-110. DOI: 10.1111/syen.12037.

Bouchard, P., Bousquet, Y., Davies, A.E. et al. (2011) Family-group names in Coleoptera (Insecta). Zookeys, 88, 1-972. DOI: $10.3897 /$ zookeys.88.807.

Cieslak, A., Fresneda, J. \& Ribera, I. (2014) Life-history specialization was not an evolutionary dead-end in Pyrenean cave beetles. Proceedings of the Royal Society of London Series B, 281, 20132978. DOI: 10.1098/rspb.2013.2978.

Eberhard, M.J.B., Pass, G., Picker, M.D., Beutel, R., Predel, R. \& Gorb, S.N. (2009) Structure and function of the arolium of Mantophasmatodea (Insecta). Journal of Morphology, 270, 1247-1261. DOI: $10.1002 /$ jmor. 10754 .

Federle, W., Rohrseitz, K. \& Hölldobler, B. (2000) Attachment forces of ants measured with a centrifuge: better "wax-runners" have a poorer attachment to a smooth surface. Journal of Experimental Biology, 203, 505-512.

Frantsevich, L. \& Gorb, S. (2004) Structure and mechanics of the tarsal chain in the hornet, Vespa crabro (Hymenoptera: Vespidae): implications on the attachment mechanism.Arthropod Structure \& Development, 33, 77-89. DOI: 10.1016/j.asd.2003.10.003.

Fresneda, J., Salgado, J.M. \& Ribera, I. (2007) Phylogeny of Western Mediterranean Leptodirini, with an emphasis on genital characters (Coleoptera: Leiodidae: Cholevinae). Systematic Entomology, 32, 332-358.

Fresneda, J., Grebennikov, V.V. \& Ribera, I. (2011) The phylogenetic and geographic limits of Leptodirini (Insecta: Coleoptera: Leiodidae: Cholevinae), with a description ofSciaphyes shestakovi $\mathrm{sp} . \mathrm{n}$. from the Russian Far East. Arthropod Systematics \& Phylogeny, 69, 99-123.

Friedemann, K., Spangenberg, R., Yoshizawa, K. \& Beutel, R.G. (2013) Evolution of attachment structures in the highly diverse Acercaria. Cladistics, 30, 170-201. DOI: 10.1111/cla.12030.

Friedemann, K., Schneeberg, K. \& Beutel, R. (2014) Fly on the wall - attachment structures in lower Diptera.Systematic Entomology, 39, 460-473. DOI: 10.1111/syen.12064.

Gers, C. (1983) Étude morphologique et biométrique de Speonomus carrerei Fourés, 1953 (Coléoptères Bathysciinae) récolté dans deux grottes et dans le milieu souterrain superficiel. Mémoires de Biopéologie, 10, 265-276.

Gers, C. (1989)Speonomus orgibetensis , n. sp., coléoptère Bathysciinae troglobie du milieu souterrain superficiel. Annales de la Société Entomologique de France (N.S.), 25, 105-116.

Gers, C. \& Dupuy, M. (1988) Une nouvelle espece remarquable du genre Speonomus (Coleoptera, Bathysciinae). Mémoires de Biospéologie, 15, 167-174.
Giachino, P.M. \& Etonti, M. (1995) Il genere Remyella Jeannel, 1931 (Coleoptera Cholevidae Leptodirinae). Atti del Museo Civico di Storia Naturale di Trieste, 46, 77-98.

Giachino, P.M. \& Vailati, D. (1993) Revisione degli Anemadinae. Monografia di Natura Bresciana, 18, 7-314.

Giachino, P.M., Vailati, D. \& Casale, A. (1998) Major questions in the phylogeny and biogeography of Cholevidae (Coleoptera), with emphasis on the subfamily Leptodirinae.Museo Regionale di Scienze Naturali di Torino Atti, 8, 179-210.

Gladun, D. (2008) Morphology of the pretarsus of the sawflies and horntails (Hymenoptera: 'Symphyta'). Arthropod Structure \& Development, 37, 13-28. DOI: 10.1016/j.asd.2007.04.002.

Gladun, D. \& Gumovsky, A. (2006) The pretarsus in Chalcidoidea (Hymenoptera Parasitica): functional morphology and possible phylogenetic implications.Zoologica Scripta, 35, 607-626.

Gnaspini, P. (1994) The genus Eucatops (Coleoptera, Cholevidae, Eucatopinae) - description of new species and considerations on its systematic position. Iheringia (Zoologia), 76, 33-42.

Gnaspini, P. (1996) Phylogenetic analysis of the tribe Ptomaphagini, with description of new Neotropical genera and species (Coleoptera, Leiodidae, Cholevinae, Ptomaphagini). Papéis Avulsos de Zoologia, 39, 509-556.

Haas, F. \& Gorb, S. (2004) Evolution of locomotory attachment pads in the Dermaptera (Insecta). Arthropod Structure \& Development, 33, 56-66. DOI: 10.1016/j.asd.2003.10.001.

Jeannel, R. (1936) Monographie des Catopidae.Mémoires du Muséum National d'Histoire Naturelle (N.S.), 1, 1-433.

Juberthie, C., Delay, B., Durand, J.P., Juberthie-Jupeau, L., Bouillon, M. \& Ruffat, G. (1981) Etude ecologique, morphologique, biometrique et biologique deSpeonomus zophosinus (Coleopteres Bathysciinae). Mémoires de Biospéologie,8, 95-124.

Lawrence, J.F., Ślipiński, A., Seago, A.E., Thayer, M.K., Newton, A.F. \& Marvaldi, A.E. (2011) Phylogeny of the Coleoptera based on morphological characters of adults and larvae. Annales Zoologici, 61, 1-217. DOI: $10.3161 / 000345411$ X576725.

McKenna, D.D., Farrell, B.D., Caterino, M.S. et al. (2015) Phylogeny and evolution of Staphyliniformia and Scarabaeiformia: forest litter as a stepping stone for diversification of nonphytophagous beetles. Systematic Entomology, 40, 35-60. DOI: 10.1111/syen.12093.

Moldovan, O.T., Racoviţă, G. \& Dunay, G. (2007) Reconsidering Pholeuon C. Hampe (Coleoptera: Leiodidae: Cholevinae), with the description of a new subgenus.Zootaxa, 1449, 31-43.

Nelson, C.H. (2009) Surface ultrastructure and evolution of tarsal attachment structures in Plecoptera (Arthropoda: Hexapoda).Aquatic Insects: International Journal of Freshwater Entomology, 31, 523-545. DOI: 10.1080/01650420802598210.

Newton, A.F. (1998) Phylogenetic problems, current classification and generic catalog of World Leiodidae (including Cholevidae).Museo Regionale di Scienze Naturali di Torino Atti,8 , 41-177.

Newton, A.F. (2005) Leiodidae Fleming, 1821. Handbook of Zoology, Vol. 4, Arthropoda: Insecta; Coleoptera,Morphology and Systematics (Archostemata, Adephaga, Myxophaga, Polyphaga partim), Vol. 1 (ed. by R.G. Beutel and R.A.B. Leschen), pp. 269-280. Walter De Gruyter, Berlin, New York, New York.

Perreau, M. (1989) De la phylogénie des Cholevidae et des familles apparentées (Coleoptera, Cholevidae). Archives des Sciences, Genève, 39, 579-590.

Perreau, M. (2000) Catalogue des Coléoptères Leiodidae Cholevinae et Platypsyllinae. Memoires de la Societé Entomologique de France,4, $1-460$.

Perreau, M. (2004) Leiodidae. Catalogue of Palaearctic Coleoptera, Vol. 2 (ed. by I. Löbl and A. Smetana), pp. 133-203. Apollo Books, Stenstrup. 
Perreau, M. \& Pavićević, D. (2008) The genus Hadesia Müller, 1911 and the phylogeny of Anthroherponina (Coleoptera, Leiodidae, Cholevinae, Leptodirini).Advances in the Studies of the Fauna of the Balkan Peninsula, Monograph 22 (ed. by D. Pavićević and M. Perreau), pp. 215-239. Institute for Nature Conservation of Serbia, Belgrade.

Philippe, H., Brinkmann, H., Lavrov, D.V., Littlewood, D.T.J., Manuel, M., Wörheide, G. \& Baurain, D. (2011) Resolving difficult phylogenetic questions: why more sequences are not enough. PLoS Biology, 9, e1000602. DOI: 10.1371/journal.pbio.1000602.

Pohl, H. \& Beutel, R. (2004) Fine structure of adhesive devices of Strepsiptera (Insecta). Arthropod Structure \& Development, 33 31-43. DOI: 10.1016/j.asd.2003.10.001.

Polak, S. \& Jalžić, B. (2009) Blattochaeta marianii kusijanovici, new subspecies (Coleoptera, Leiodidae, Cholevinae) from Croatia. Natura Croatica, 18, 15-27.

Salgado, J.M. (2010) Descripción de una nueva especie del género Paulipalpina y de tres nuevas especies del géneroAdelopsis de Ecuador (Coleoptera, Leiodidae, Cholevinae).Nouvelle Revue d'Entomologie (N.S.), 26, 205-229.
Salgado, J.M. (2013a) Descripción de varios taxones nuevos de Ptomaphagini de Ecuador y otros datos de interés (Coleoptera, Leiodidae, Cholevinae). Nouvelle Revue d'Entomologie (N.S.), 29 , 57-83.

Salgado, J.M. (2013b) El género Paulipalpina Gnaspini \& Peck, 1996 en Perú (Coleoptera: Leiodidae: Cholevinae: Ptomaphagini). Nuevas especies y nuevos datos.Elytron, 26, 7-22.

Schulmeister, S. (2003) Morphology and evolution of the tarsal plantulae in Hymenoptera (Insecta), focussing on the basal lineages. Zoologica Scripta, 32, 153-172.

Vailati, D. (1998) Ridescrizione di Orostygia tibialis Paoletti, 1979 (Coleoptera Cholevidae Leptodirinae) buona specie del Massiccio Cansiglio-Monte Cavallo (Prealpi Venete). Natura Bresciana, 31, 121-128.

Weirauch, C. (2005) Pretarsal structures in Reduviidae (Heteroptera, Insecta).Acta Zoologica , 86, 91-110.

Accepted 25 October 2015

First published online 1 December 2015 
CAPÍTULO 2 



\title{
Cephalic anatomy and three-dimensional reconstruction of the head of Catops ventricosus (Weise, 1877) (Coleoptera: Leiodidae: Cholevinae)
}

\author{
Caio Antunes-Carvalho ${ }^{1,2}$ - Margarita Yavorskaya ${ }^{2}$ - Pedro Gnaspini ${ }^{1}$. \\ Ignacio Ribera $^{2,3}$ • Jörg U. Hammel ${ }^{4}$. Rolf Georg Beutel ${ }^{2}$
}

Received: 7 July 2016 / Accepted: 4 October 2016

(C) Gesellschaft für Biologische Systematik 2016

\begin{abstract}
Adult head structures are well known in the coleopteran suborders Archostemata and Adephaga, whereas the available information is very fragmentary in the megadiverse Polyphaga, including the successful superfamily Staphylinoidea. In the present study, the cephalic morphology of the cholevine species Catops ventricosus is described in detail and documented. The results were compared to conditions occurring in other polyphagan lineages, especially staphylinoid and scarabaeoid representatives. Specific external features documented in Catops and potential autapomorphies of Leiodidae include a five-segmented antennal club with a reduced eighth antennomere and the presence of periarticular grooves filled with sensilla on antennomeres 7 , 9 , and 10. The firm connection of the head and pronotum is possibly an apomorphy of Cholevinae. The monophyly of Cholevinae excluding Eucatopini and Oritocatopini is supported by the apical maxillary palpomere as long as or shorter than the subapical one, and the presence of cryptic pore plates on the surface of these palpomeres-a feature described and documented here for the first time. The internal cephalic
\end{abstract}

Caio Antunes-Carvalho

cantunescarvalho@gmail.com

1 Departamento de Zoologia, Instituto de Biociências, Universidade de São Paulo, Rua do Matão, Travessa 14, no. 101, 05508-090 São Paulo, SP, Brazil

2 Entomology Group, Institut für Spezielle Zoologie und Evolutionsbiologie mit Phyletischem Museum, FSU Jena, Erbertstrasse 1, 07743 Jena, Germany

3 Instituto de Biología Evolutiva (CSIC-Universitat Pompeu Fabra), Passeig Maritim de la Barceloneta 37-49, 08003 Barcelona, Spain

4 Institute of Materials Research, Helmholtz-Zentrum Geesthacht, Max-Planck-Str. 1, 21502 Geesthacht, Germany structures of Catops are mostly plesiomorphic, as for instance the complete tentorium. The pattern of the muscles is similar to what is found in other staphylinoid taxa. The unusual maxillary muscle "Mx" is likely a groundplan apomorphy of the clade Staphyliniformia + Scarabaeoidea. M. hypopharyngomandibularis (M13) was identified in Catops and is ancestral for Coleoptera, even though it is often missing. The same applies to $M$. tentoriohypopharyngalis (M42).

Keywords Catops $\cdot$ Leiodidae $\cdot$ Head morphology $\cdot 3 \mathrm{D}$ reconstruction $\cdot$ Musculature $\cdot$ Staphyliniformia .

Staphylinoidea

\section{Introduction}

It was shown in previous studies on Archostemata (Beutel et al. 2008b) and Adephaga (Dressler and Beutel 2010) that the cephalic anatomy of Coleoptera is a complex and phylogenetically informative character system, which can also reveal important insights in life strategies, especially but not only in the context of feeding. The available information on adult head structures of Coleoptera has considerably increased in the last decade, facilitated by advanced morphological techniques (e.g., Beutel et al. 2008b; Anton et al. 2016). Head structures of Archostemata (Hörnschemeyer et al. 2002; Beutel et al. 2008b), Adephaga (e.g., Dressler and Beutel 2010) and the myxophagan family Lepiceridae (Anton and Beutel 2006) are very well known. In contrast, the available information on the cephalic morphology of the megadiverse Polyphaga is still very fragmentary. Earlier studies are those of Dönges (1954) on the weevil Cionus or the study of Schneider (1981) on the Spanish fly Lytta (Meloidae), both highly specialized taxa of Cucujiformia. Anatomical data on the 
presumably basal Scirtoidea (McKenna et al. 2015a) became available only recently (Anton et al. 2016) and detailed studies on the extremely species-rich Staphylinoidea are still very sparse. Interestingly, larval head structures are relatively well known (e.g., Beutel and Molenda, 1997; Beutel and Leschen 2005), whereas detailed data on adult cephalic structures are only available for few species of the aquatic Hydraenidae (Beutel et al. 2003), the strongly miniaturized Ptiliidae (Polilov and Beutel 2009), the small family Agyrtidae (Weide and Betz 2009), and few species of the highly diverse Staphylinidae (Weide and Betz 2009; Weide et al. 2010, 2014).

With 4135 described species (Newton 2016), Leiodidae are the second largest family of Staphylinoidea. Their distribution is worldwide, and they are able to explore an astonishing range of habitats and food resources. In general, leiodid beetles inhabit forested landscapes and are mycophagous relying on various groups of fungi or saprophagous and feeding on different kinds of decaying organic matter involving plant material (e.g., organic matter in the soil, leaf litter), animal matter (e.g., dung, carrion) or the yeasts, and bacteria associated with such substrates (Newton 2016). The family is currently organized into six subfamilies and 18 tribes. About half of the total species diversity belongs to Cholevinae, the most species-rich subfamily, encompassing seven tribes and 17 subtribes (Perreau 2000; Bouchard et al. 2011). There is no broad formal cladistic study available focused on Leiodidae or Cholevinae. The only phylogenetic contributions including these groups are broad-scale analyses with insufficient taxonomic sampling regarding subordinate taxa in Leiodidae, or more detailed studies on particular lineages, thus not providing a well-supported phylogenetic scheme at the family or subfamily level. In this context, Fresneda et al. (2011) is the most complete molecular study with emphasis on Cholevinae. Whereas some studies did not confirm the monophyly of Leiodidae (e.g., Lawrence et al. 2011; McKenna et al. 2015a) or Cholevinae (e.g., Fresneda et al. 2011; McKenna et al. 2015a), both have been supported as natural groups based on morphological characters evaluated by Newton (1998, 2016). Therefore, the higher level classification remains an important area of investigation in the systematics of Leiodidae.

The knowledge on the morphology of Cholevinae is predominantly limited to general external features and genitalia, mostly documented and described based on stereomicroscopy and light microscopy, and mainly aiming at taxonomic descriptions. The head morphology of Cholevinae has never been studied in detail, especially the internal soft parts. This contribution aims to explore the cephalic character complex of a representative of Cholevinae by providing a detailed description of the head of Catops ventricosus (Weise, 1877). The exo- and endoskeletal structures, musculature, nervous system, and digestive tract were studied and documented using scanning electron microscopy, micro-computed tomography, and computer-based three-dimensional reconstructions. The first 3D model of the head of Leiodidae is provided, and the morphological elements are discussed from a phylogenetic point of view. The morphological descriptions and documentation presented here offer the basis for future inferences on the higher level systematics of Leiodidae using cephalic structures as a source of characters.

\section{Material and methods}

This study is based on adults of $C$. ventricosus collected inside Arılı Mağarasi, a cave in Gümüşhane, Turkey (1777 m, N $40^{\circ}$ $26^{\prime} 50.8^{\prime \prime}$ E $39^{\circ} 19^{\prime} 19.1$ ). This species lacks sexual dimorphism associated with cephalic characters. Specimens were investigated using scanning electron microscopy (SEM) and synchrotron radiation micro-computed tomography (SR- $\mu \mathrm{CT}$ ). For SEM, the specimen was dried at the critical point (Emitech K850 critical point dryer), sputter-coated with gold (Emitech K500), and fixed on a rotatable specimen holder (Pohl 2010). Images were taken with a FEI (Philips) XL 30 ESEM at $10 \mathrm{kv}$. Specimens used for SR- $\mu$ CT were dehydrated with ethanol (20-100\%) and acetone, dried at the critical point (Emitech K850 critical point dryer), and mounted on a standardized specimen holder. Micro-computed tomography was performed at the Deutsches Elektronen Synchrotron (DESY, beamline IBL P05 at PETRA III, operated by the Helmholtz-Zentrum Geesthacht, Hamburg, Germany) with a stable beam energy of $8 \mathrm{keV}$ in attenuation contrast mode (Beckmann et al. 2008; Greving et al. 2014). We used an effective magnification of $\times 18$ providing a resulting field of view of $2 \mathrm{~mm} \times 2 \mathrm{~mm}$, resulting in an effective pixel size of $1.33 \times 1.33 \mu \mathrm{m}$ in the two times binned reconstructed data set. Radiograms $(n=1200)$ were taken at equal intervals between 0 and $\pi$ (exposure time of $6.3 \mathrm{~s}$ ). Stacks of $\geq 899$ slices were calculated from each set of radiograms using the tomographic reconstruction algorithm "back projection of filtered projections" (Huesman et al. 1977).

Three-dimensional models of head structures are provided. Uncompressed 16bit TIFF image stacks were imported into Amira 5.3.1 (Visage Imaging, Berlin, Germany) where the segmentation of individual structures was conducted. These were subsequently exported to VGStudio MAX 2.0.5 (Volume Graphics, Heidelberg, Germany) for volume rendering.

Detailed morphological studies on the head of staphyliniform and scarabaeoid beetles were used for comparison (e.g., Jäch et al. 2000; Beutel et al. 2001, 2003; Anton and Beutel 2004; Polilov and Beutel 2009; Weide and Betz 2009; Weide et al. 2010; Anton and Beutel 2012). The muscles are named following the terminology of von Kéler (1963). 


\section{Results}

\section{External head capsule}

The posterior part of the prognathous head is abruptly narrowed thus forming a distinct neck region, which lies on a lower level dorsally and is retracted into the prothorax (Figs. 1 and 2). The posterodorsal border of the exposed part of the head is delimited by an occipital crest, which is firmly connected to the anterior edge of the pronotum (oc, Fig. 2a, e). The head capsule is mostly black, but the appendages vary from dark yellowish brown (antennae, maxillary palps, and most parts of cardo and stipes) to pale yellow (galea, lacinia, and labial palps) (Fig. 1). The dorsal surface of the head except for the neck region is microgranulated and densely covered with regularly distributed, medium length yellowish setae (Fig. 1a, c). The dorsal punctures are enclosed by a distinct rim (Fig. 2b). Setae are also present on most parts of the ventral side of the head, except for the gula (Fig. 2c). The ventral cuticular surface is weakly striated on the mentum and submentum, strongly striated on the genae, and strongly reticulated on the gula (Fig. 2c). The frontoclypeal strengthening ridge is not visible externally (Fig. 2d). The clypeus is moderately sized. Its subparallel lateral margins are approximately one third as long as the straight anterior margin (Fig. 2d). The lateral and anterolateral borders are weakly demarcated by an indistinct ridge which obliterates in the middle region of the anterior border. The lateral surface of the frons anterior to the compound eyes is roundly excavated, and the antennal insertion is fully exposed in this region (Fig. 2a). Ocelli are absent. The compound eyes are moderately sized, with a distinctly convex surface and numerous small lenses of the individual ommatidia, and few scattered setae. The anterior edge is evenly rounded whereas the vertical posterior margin is nearly straight. Posteriorly, the compound eye is covered by a genal fold (pogf, Fig. 2c) and delimited by a large postocular ridge (por, Fig. 2d). The gula is large and has the shape of an elongated trapezium. It is anteriorly delimited by a smooth transverse depression of its surface and appears convex in lateral view (Fig. 2c). The widely separated anteriorly converging gular sutures are very distinct externally and fissure-shaped. The posterior tentorial pits are not distinctly recognizable externally.

\section{Cephalic endoskeleton}

The paired anterior, dorsal, and posterior tentorial arms (ata, dta, pta, Fig. 5a) are well developed. The extensive gular ridges form wall-like structures and are fused with the posterior edge of posterior arms ("PTW" in Weide et al. 2014). They are connected by a thin tentorial bridge or corpotentorium, which is straight in posterior view, with a sinuously curved posterior margin, thus appearing W-shaped in dorsal view (tb, Fig. 5a). The posterior tentorial arms converge anteriorly and merge medially forming a massive median tentorial body or laminatentorium (lt, Fig. 5a). This structure is composed of a median vertical plate dorsally continuous with a horizontal plate ("hpl" in Anton and Beutel 2004), which is not directly connected with the tentorial arms. The median vertical plate produces a frontally projecting, median vertical lamella (mvl, Fig. 5b). The elongate anterior and dorsal tentorial arms arise from the posterior arms, posterior to the horizontal plate of the laminatentorium. The apically narrow dorsal arms extend towards the dorsal wall of the head capsule at the level of the compound eyes, ending between the longitudinal midline of the head and the dorsal margin of the eyes (Fig. 6b). The anterior arms arise with a relatively robust proximal part at the edge of the frons, close to the antennal foramen (Figs. $4 \mathrm{~d}$ and $6 \mathrm{~b}$ ). The anterior tentorial pits are not visible externally.

\section{Labrum}

The transverse labrum is connected to the clypeus by an internal membrane. It is ca 2.5 times as wide as long and well visible from above (Fig. 3h). The anterolateral edges are rounded, whereas the median portion of the anterior margin is broadly emarginated and bears a dense fringe of setae (Fig. 3h). The dorsal surface is largely smooth, but a sparse vestiture of anteriorly directed setae is present. The dorsal surface is posteriorly delimited by a distinct transverse ridge (trdg, Fig. 3h), which is covered by the apical clypeal margin. The anteromedial region of the ventral side bears a cluster of blunt protuberances and a field of mesally directed microtrichia (Fig. 3i). It is followed posteriorly by a longitudinal epipharyngeal process densely covered with
Fig. 1 Catops ventricosus, head, habitus, photomicrographs. a Dorsal view. b Ventral view. c Frontal view. Images produced by focus stacking
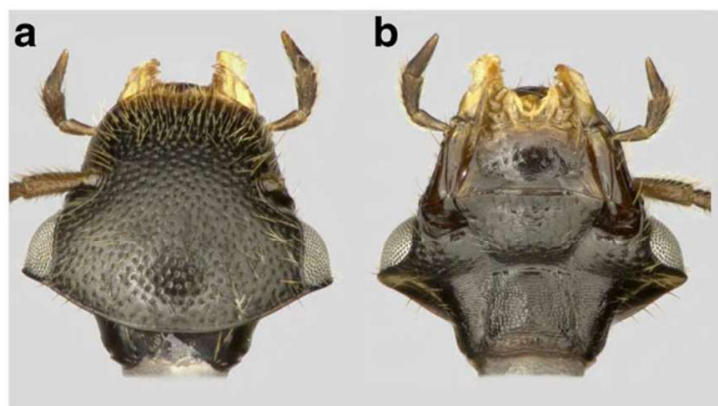

C

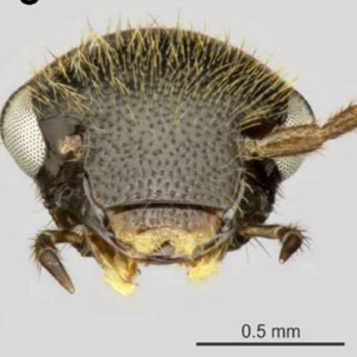




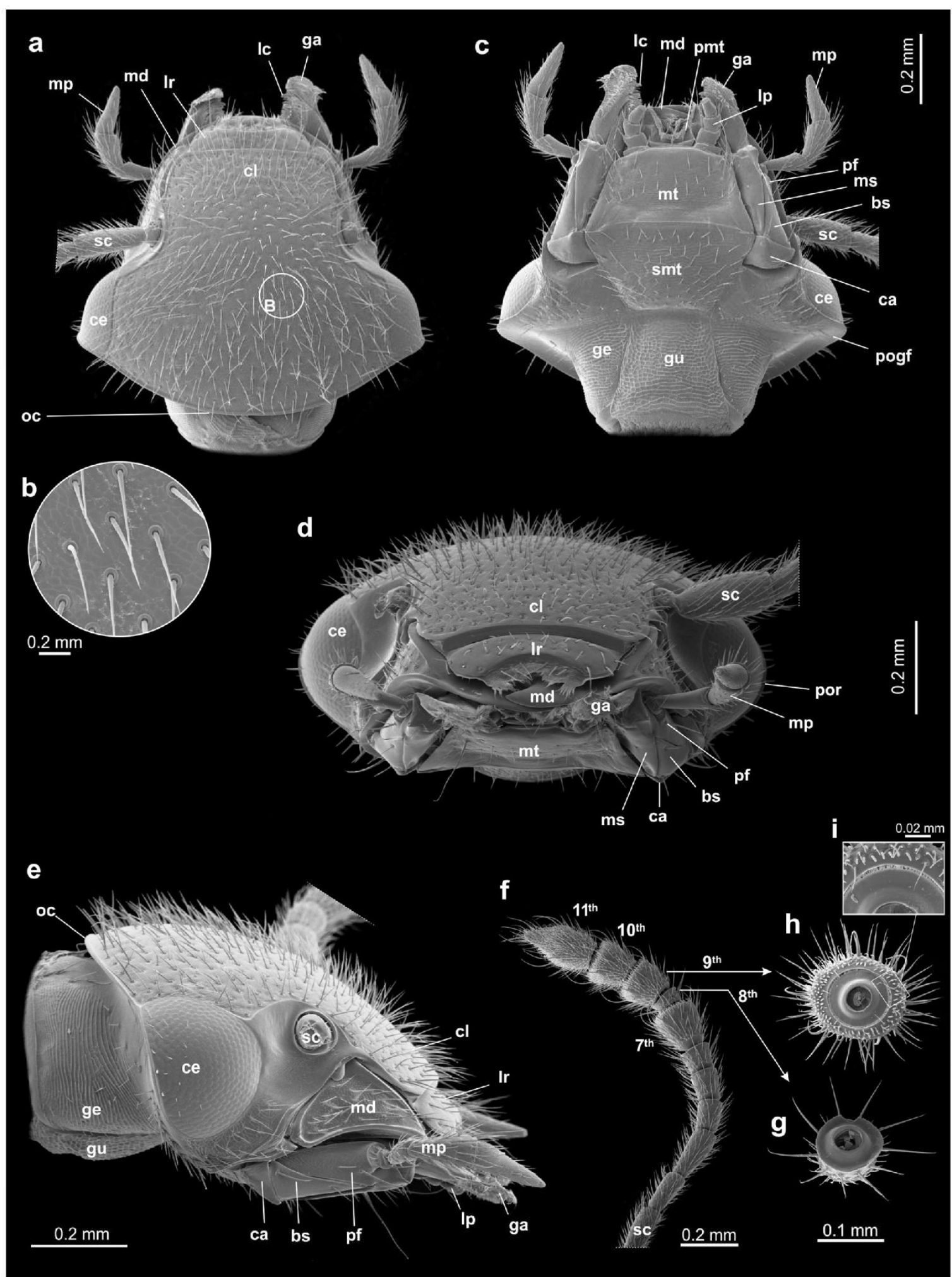

Fig. 2 SEM micrographs of the head of Catops ventricosus. a Dorsal view. b Dorsal surface of vertex. $\mathbf{c}$ Ventral view. $\mathbf{d}$ Frontal view. e Lateral view. f Antenna. $\mathbf{g}$ Eighth antennomere. $\mathbf{h}$ Ninth antennomere. i Detail of the narrow slit opening on the distal surface of the ninth antennomere. $b s$ basistipes, $c e$ compound eye, $c l$ clypeus, $c a$ cardo, $g a$ galea, ge gena, gu gula, $l c$ lacinia, $l p$ labial palp, $l r$ labrum, $m d$ mandible, $m p$ maxillary palp, $m s$ mediostipes, $m t$ mentum, oc occipital crest, $p f$ palpifer, pmt prementum, pogf postocular genal fold, por postocular ridge, smt submentum, $s c$ scapus 


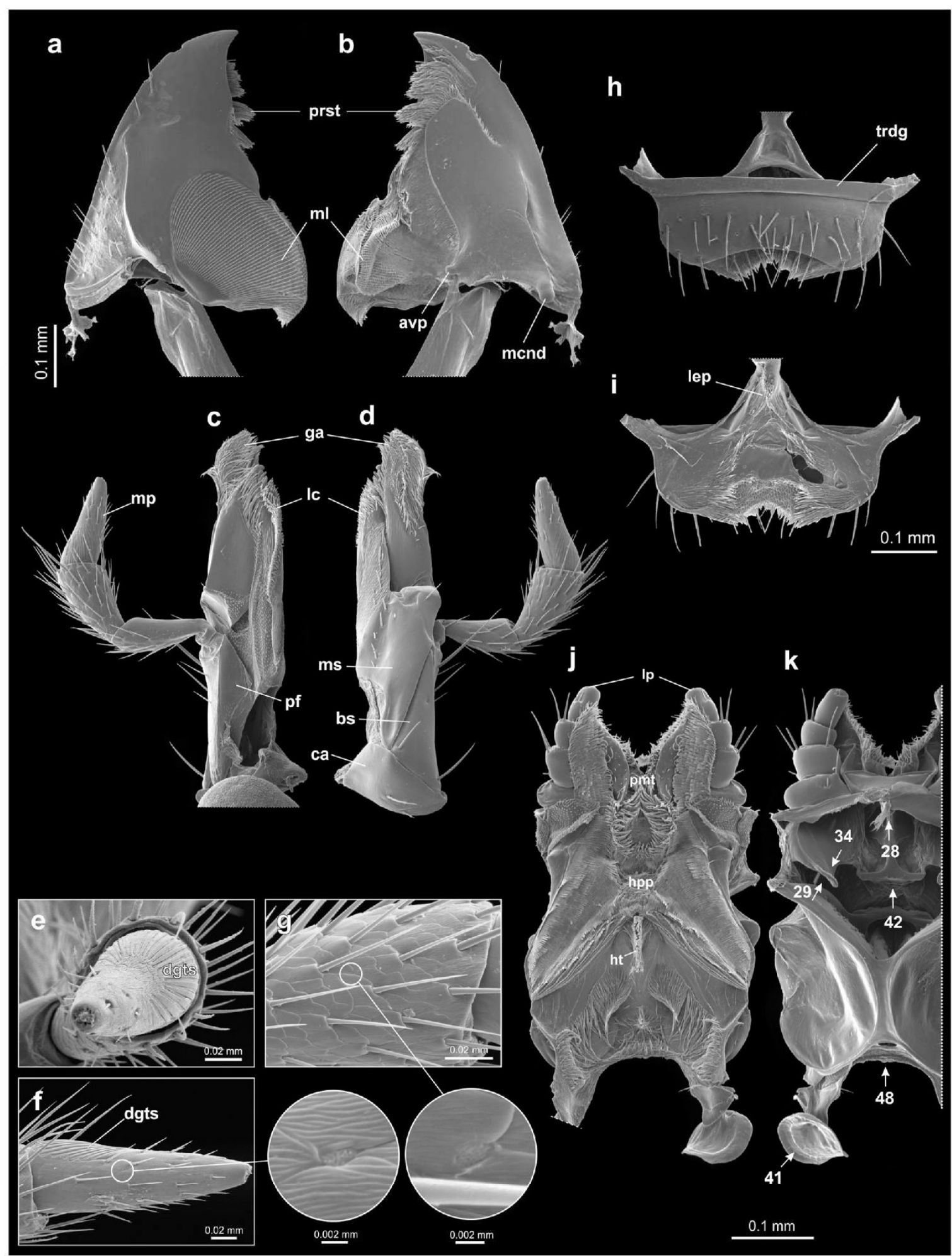

Fig. 3 SEM micrographs of the mouthparts of Catops ventricosus. a Dorsal view of left mandible. b Ventral view of left mandible. $\mathbf{c}$ Dorsal view of left maxilla. d Ventral view of left maxilla. e Dorsal view of apical maxillary palpomere. $\mathbf{f}$ Lateral view of apical maxillary palpomere. $\mathbf{g}$ Lateral view of subapical maxillary palpomere. $\mathbf{h}$ Dorsal surface of labrum. i Ventral surface of labrum. $\mathbf{j}$ Dorsal surface of hypopharynxprementum complex. $\mathbf{k}$ Ventral surface of hypopharynx-prementum complex, with arrows indicating areas of origin of selected cephalic muscles.
The details in $\mathbf{f}$ and $\mathbf{g}$ show pore plates on the surface of the apical and subapical maxillary palpomere, respectively. avp mandibular accessory ventral process, $b s$ basistipes, $c a$ cardo, dgts digitiform sensilla, $g a$ galea, $h p p$ hypopharynx, $h t$ tuft of hairs of the hypopharynx (or longitudinal hypopharyngeal process), lep longitudinal epipharyngeal process, $l c$ lacinia, $l p$ labial palp, $m c n d$ mandibular condyle, $m l$ mola, $m p$ maxillary palp, $m s$ mediostipes, $p f$ palpifer, $p m t$ prementum, prst prostheca, $t r d g$ transversal dorsal ridge. For muscle determination, see the main text 
microtrichia (lep, Fig. 3i). Paired paramedian patches of sensilla are present close to the posterior portion of the fields of microtrichia.

Musculature: Musculus labroepipharyngalis (M7)—-(origin $=0$ ) posteriorly on the dorsal wall of labrum; (insertion = I) posteriorly on the ventral wall of labrum (posterior to area of origin) (Figs. 4a and 6a). M. frontoepipharyngalis (M9)absent.

\section{Antenna}

The insertion of the 11-segmented (Fig. 2f) antenna is clearly visible from above (Fig. 2a). The scapus is composed of a nearly globular articulatory piece and an elongated cylindrical shaft. The cylindrical pedicellus is shorter and also shorter than the elongated antennomere 3 . The following segments are distinctly shorter and slightly widening distally. Segment 6 is wider than long. Antennomeres 7-11 form an indistinct club. Antennomere 7 is large and cupola-shaped and its apical part partly covers the small antennomere 8 (Fig. 2f). Segments 9 and 10 are almost as large as 7 and similarly shaped. The terminal antennomere 11 is elongate and subconical on its distal half (Fig. 2f). A distal periarticular gutter bearing sensilla is present on antennomeres 7,9 , and 10, visible through a narrow slit-like opening on the apical surface of these segments
(Fig. 2h, i; compare with Fig. 2g). All antennomeres are densely covered with setae. Some longer, curved setae are distributed laterally along the distal face of the antennomeres 7, 9, and 10 , close to the apical border. On the distal antennomere, the setae are laterally inserted at the end of the most expanded part of the segment and also at the apex (Fig. 2f). Numerous short peg-like sensilla are present at the distal margin of antennomeres 7, 9, and 10 (Fig. 2i). Some thinner, longer proprioceptive sensilla are also present on these antennomeres, oriented towards the central axis of the antennae (Fig. 2h, i).

Musculature: $M$. tentorioscapalis anterior (M1) - (O) the dorsal face of horizontal plate of laminatentorium, passing below the anterior portion of the anterior tentorial arm; (I) ventrally on articulatory piece of scapus (Fig. 4d, e). M. tentorioscapalis posterior $(\mathrm{M} 2)-(\mathrm{O})$ the lateral side of the posterior tentorial arm; (I) medioposteriorly on articulatory piece of scapus, posterior to insertion of M4 (Fig. 4e). M. tentorioscapalis medialis (M4)-(O) lateral face of anterior tentorial arm and basal portion of dorsal tentorial arm; (I) medially on articulatory piece of scapus (Fig. 4e).

\section{Mandible}

The mandibles are largely symmetrical, with the lateral margins somewhat rounded (Fig. 3a, b). The external side is broad at the
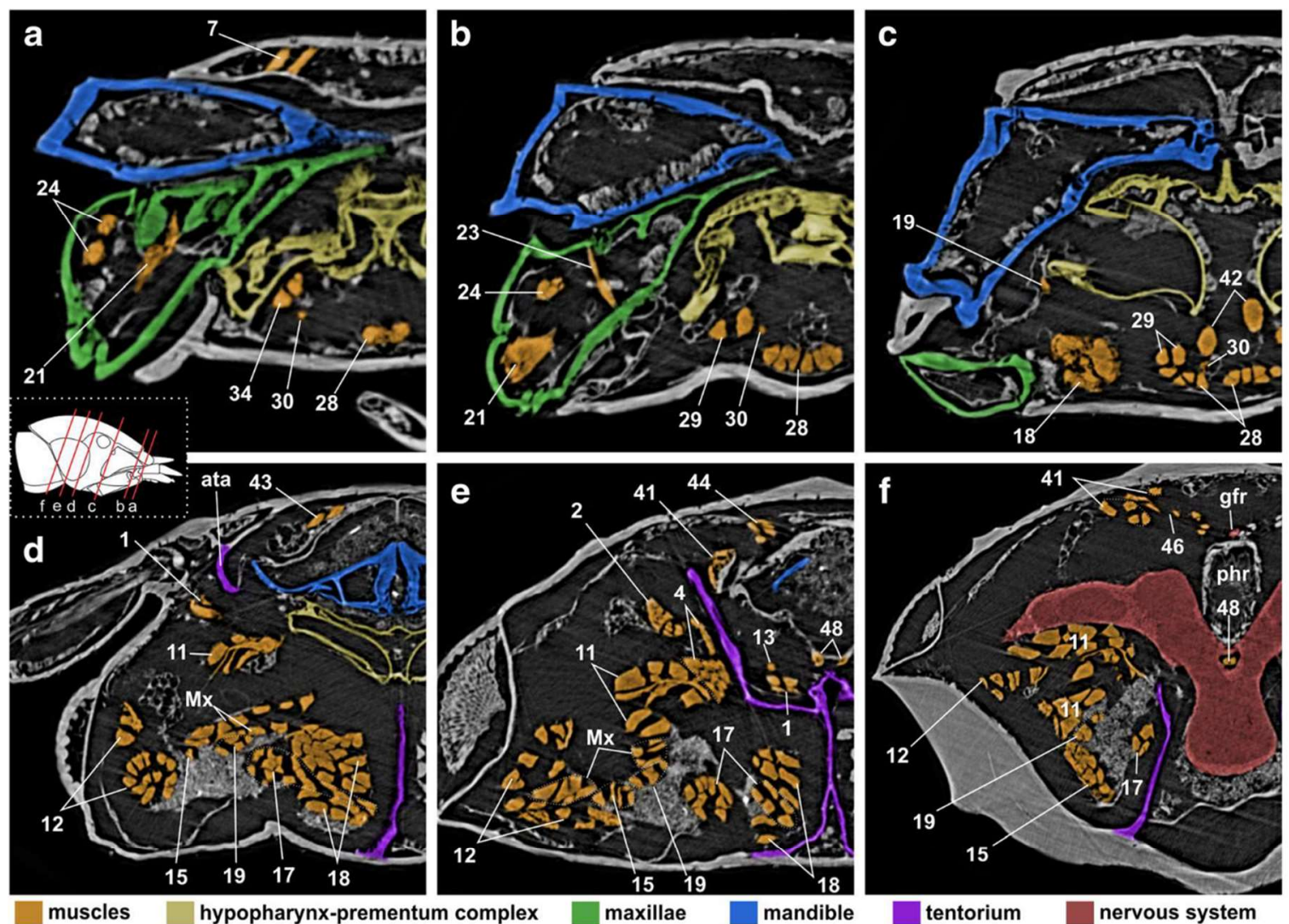

Fig. 4 Transverse $\mu \mathrm{CT}$ sections through the head of Catops ventricosus. a-f Sections in anterior-posterior sequence. ata anterior tentorial arm, gfr frontal ganglion, $p h r$ pharynx. See the main text for muscle identifications 
base and narrows towards a moderately acute apex, which is proximally adjoined by a sinuous, dorsal cutting edge (Fig. 3a). A retinaculum, in the form of a very weakly developed blunt process, is present at midlength between the mandibular apex and the distal margin of the mola (Fig. 3a). It is slightly more prominent on the right mandible. The well-developed prostheca bears a dense brush of long microtrichia along the mesal border of the ventral mandibular side, from the incisor area to the mola (prst, Fig. 3b). On the ventral face of the mandible, a weak elevation occupies a large area of the mesal region of the surface. A row of hairs arises from the distal and mesal limits of this area (Fig. 3b). A ventral accessory process is present mesally close to the basal mandibular edge (avp, Fig. 3b). Oblique rows of posteriorly directed microtrichia characterize the dorsal surface of the large mola (ml, Fig. 3b). The molar area is delimited by a slight depression of the mandibular surface and is therefore not firmly united to the rest of the mandible (condition defined as "loosely attached" in Betz et al. 2003). Its mesal grinding surface is densely covered by regularly distributed asperities or small denticles, while the ventral surface bears dense rows of short hairs.

Musculature: M. craniomandibularis internus (M11)-(O) posterolateral area of the head capsule, slightly posterior to the eyes, and from the posteriormost cephalic region lateral the occipital foramen; (I) medially on mandibular base, with strong adductor tendon (Figs. 4d-f and 5a). M. craniomandibularis externus (M12) - (O) genal region, and from the posteriormost part of the head capsule, close to the occipital foramen and attachment area of M11; (I) laterally on mandibular base with abductor tendon (Figs. 4d-f and 5a). M. hypopharyngomandibularis (M13), a thin muscle- $(\mathrm{O})$ from region of posterodorsal surface of laminatentorium but exact point of origin not recognizable; (I) medially on mandibular base, relatively close to insertion of M11 (Figs. 4e and 5a).

\section{Maxillae}

The moderately deep maxillary grooves anteromesad the compound eyes have a smooth surface. They are mesally bordered by the anterior third of the lateral edge of the submentum, and posteriorly and laterally by a distinct curved line. A distinct lateral genal edge is present above the lateral maxillary base and extends anteriorly forming an acute lobe below the ventral mandibular base. The short transverse cardo is rounded posterolaterally and has nearly straight anterior and mesal edges (ca, Figs. 2c and 3d). It is mostly glabrous, with only four setae on its basal part. The basistipes is elongate and triangular, with a single seta at each corner (bs, Fig. 3d). The mediostipes (ms, Fig. 3d) is continuous with the lacinia, which is long and narrow (lc, Fig. 3c). Its mesal edge bears a semimembranous seam densely covered with microtrichia, while the ventral surface is mostly covered with small cuticular protuberances. The apex is strongly sclerotized and hook-
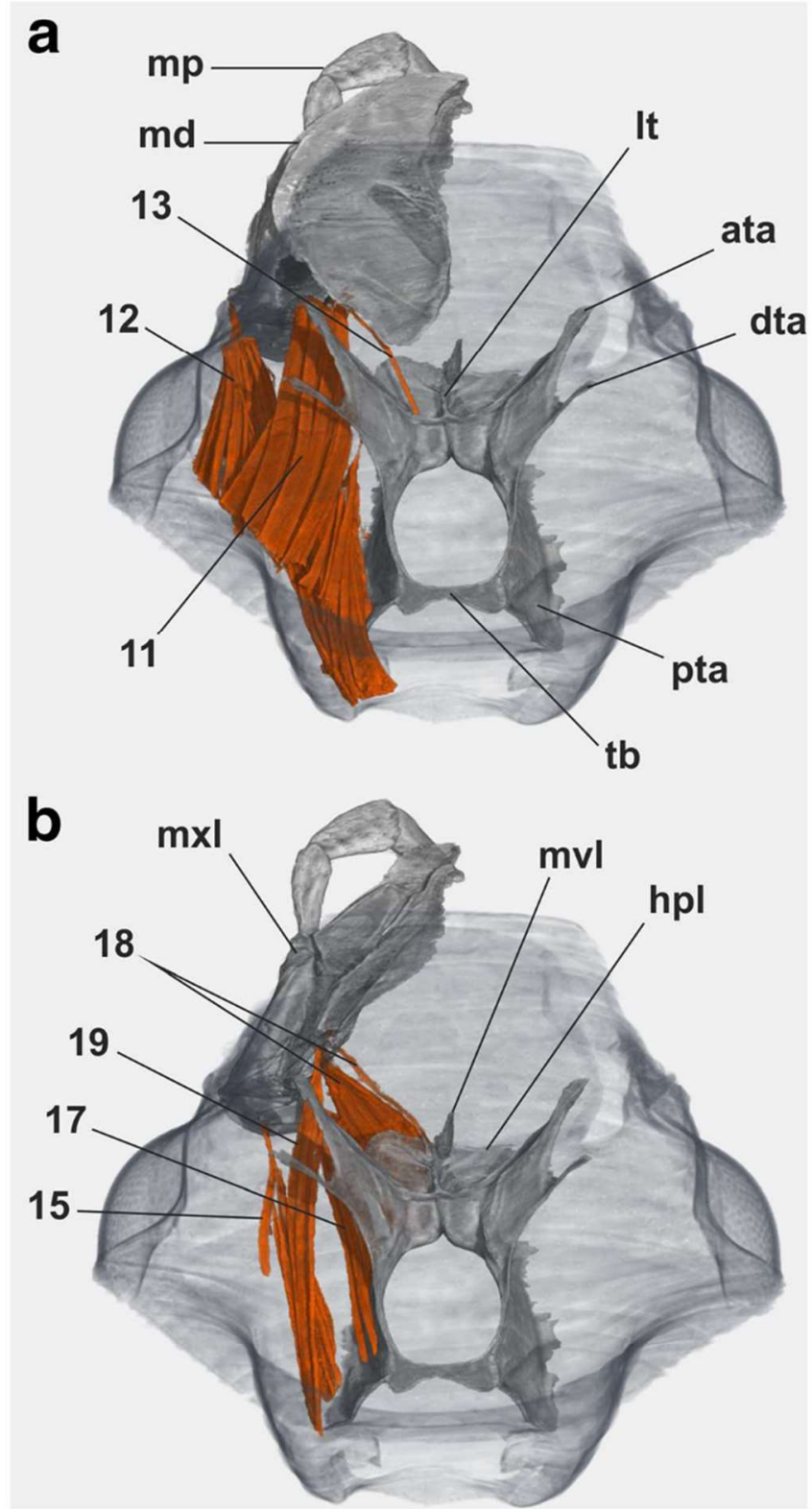

Fig. 5 3D reconstructions of the head capsule, tentorium, and muscles associated to mandible and maxilla of Catops ventricosus. a Dorsal view of the mandibular muscle system. b Dorsal view of the maxillar muscle system. ata anterior tentorial arm; dta dorsal tentorial arm, $h \mathrm{pl}$ horizontal plate of the laminatentorium, lt laminatentorium, $m d$ mandible, $m p$ maxillary palp, $m v l$ median vertical lamella of the laminatentorium, $m x l$ maxilla, $p t a$ posterior tentorial arm, $t b$ tentorial bridge

shaped. The subapical edge bears a dense set of thorn-like structures (Fig. 3c). The galea is composed of a short proximal segment, subtriangular in ventral view (ga, Fig. 3c). The distal segment is elongate, with a dense apical brush of setae and a fringe of long setae along the mesal edge of the dorsal side. Small finger-like cuticular protuberances are present on the anteromesal edge of the ventral face (Fig. 3c, d). The palpifer is elongate and subtriangular (pf, Fig. 3c). The palp is foursegmented (mp, Fig. 3c). Palpomere I is very short, whereas 
the palpomeres II-IV are about twice as long as the maximum width. Palpomeres II and III are distinctly widening distally and slightly curved inwards. Palpomere IV is conical and apically rounded. A parallel arrangement of about 20 digitiform sensilla is present on its dorsal surface (dgts, Fig. 3e, f). Small pore plates are distributed over the surface of palpomeres III and IV (Fig. 3f, g), and a sensorial field is present at the apex of palpomere IV.

Musculature: M. craniocardinalis externus (M15)-(O) anterolateral genae, at the level of the compound eyes (thin, single bundle), posterior head region, laterally on basal portion of gular ridge; (I) end of dorsally directed process of cardo base (Figs. 4d-f and 5b). M. tentoriocardinalis (M17)-(O) along lateral surface of posterior tentorial arms; (I) sclerotized process of cardo base (Figs. 4d-f and 5b). M. tentoriostipitalis (M18)(O) lateral face of median vertical lamella and median vertical plate of laminatentorium, and from anterior extension of the posterior tentorial arm; (I) ventromesally on stipes (Figs. 4c-e and 5b). M. craniolacinialis (M19)-(O) posterior region of ventral surface of the head capsule, immediately posterior to main attachment area of M15; (I) on the membranous area close to the basal margin of lacinia (Figs. 4c-f and 5b). M. stipitolacinialis (M20), arranged diagonally on base of maxillae-(O) lateral base of basistipes; (I) base of lacinia. M. stipitogalealis (M21), arranged longitudinally on maxillary base - (O) lateral base of basistipes, anterior to origin of M20; (I) base of galea (Fig. 4a, b). M. stipitopalpalis internus (M23), short muscle arranged vertically in basal part of maxillae between insertions of M20 and M21-(O) mediostipes; (I) palpifer (Fig. 4b). M. palpopalpalis maxillae primus (M24), arranged longitudinally within palpifer- $(\mathrm{O})$ base of palpifer; (I) base of basal maxillary palpomere (Fig. 4a, b).

\section{Labium}

The anteriorly widening submentum is about as large as the mentum and anteriorly delimited by a very slightly convex transverse suture. Its basal margin is not separated from the gula by a suture but the border is clearly indicated by the anterior transverse gular depression and a distinct angle formed by both areas (Fig. 2c). The anterior third of the lateral submental edge forms the mesal margin of the maxillary grove and is adjacent with the cardo. The broad plate-like mentum is trapezoidal and narrowing anteriorly. The converging lateral margins are almost straight (Fig. 2c) and adjacent with the mediostipes. The posterolateral edges of the mentum are levelled with the anterior cardinal margin. The anterior margin is slightly convex. The submental and mental surface is transversely striated and bears a vestiture of short setae, with a slightly higher density on the submentum. In ventral view, the mentum covers part of the base of the prementum. The prementum is completely divided medially (pmt, Fig. 3j).
Fig. 6 3D reconstructions of the head of Catops ventricosus. a Sagittal view. b Frontal view, transparent cuticle. The muscles associated with mandible, maxilla, and antenna are not included. Antennae and mouthparts on right side removed in b. ata anterior tentorial arm, cer cerebrum, $d t a$ dorsal tentorial arm, epp epipharynx, gfr frontal ganglion, hpp hypopharynx, $l r$ labrum, $m d$ mandible, $m p$ maxillary palp, $m t$ mentum, $p h r$ pharynx, pta posterior tentorial arm, soe subesophageal ganglion, $t b$ tentorial bridge

The paired lobes are elongate-ovoid and diverge anteriorly. Longitudinal prominent rows of mesally directed microtrichia are present on the dorsal surface. The mesal edge is densely covered with a row of setae (Fig. 3j). The prementum is laterally connected with a pair of transverse palpigers (Fig. 3j, k). The palps are three-segmented (lp, Fig. $3 \mathrm{k}$ ). The basal palpomeres are wider than the apical ones. The apical palpomere is longer than the subapical one, and approximately as long as the basal one. All palpomeres are subcylindrical. The laterodistal margin of the basal and subapical palpomere bears a few long setae (two or three). The apical surface of the distal palpomere bears a field of sensilla.

Musculature: M. submentopraementalis (M28)-(O) paramedially on anterior part of the submentum; (I) medially on membranous fold between the prementum and mentum (Figs. 3k, 4a-c, and 6a). M. tentoriopraementalis inferior (M29)- $(\mathrm{O})$ paramedially on the submentum, posterior to origin of M42; (I) posteriorly on sclerotized mesally directed process of the lateral wall of the prementum (see origin of M34) (Figs. 3k, 4b, c, and 6a). $M$. tentoriopraementalis superior (M30), very thin muscle- $(\mathrm{O})$ medially on the submentum, posterior to origin of M28, and close to origin of M42; (I) basal labial palpomere (Figs. $4 \mathrm{a}-\mathrm{c}$ and $6 \mathrm{a}$ ). M. praementopalpalis externus (M34)- $(\mathrm{O})$ anterior surface of sclerotized, mesally directed process of the lateral wall of the prementum; (I) basal margin of basal palpomere (Figs. 3k, 4a, and 6a).

\section{Epipharynx}

An epipharyngeal process projects medially from the posterior margin of the ventral side of the labrum (lep, Fig. 3i). This structure is subtriangular, relatively broad at its base and narrowing towards its apex. It is densely covered with posteriorly directed microtrichia (Fig. 3i). The posterior part of the epipharynx (not shown in Fig. 3i) is laterally fused with the corresponding edges of posterior hypopharynx forming a short, closed prepharyngeal tube (Fig. 6a).

Musculature: M. clypeopalatalis (M43), multiple short bundles - (O) along the clypeal area; (I) the dorsal wall of the cibarium (Figs. 4d and 6). M. clypeobuccalis (M44)(O) frons, anterior to M45; (I) the dorsolateral wall of the posterior epipharynx. 

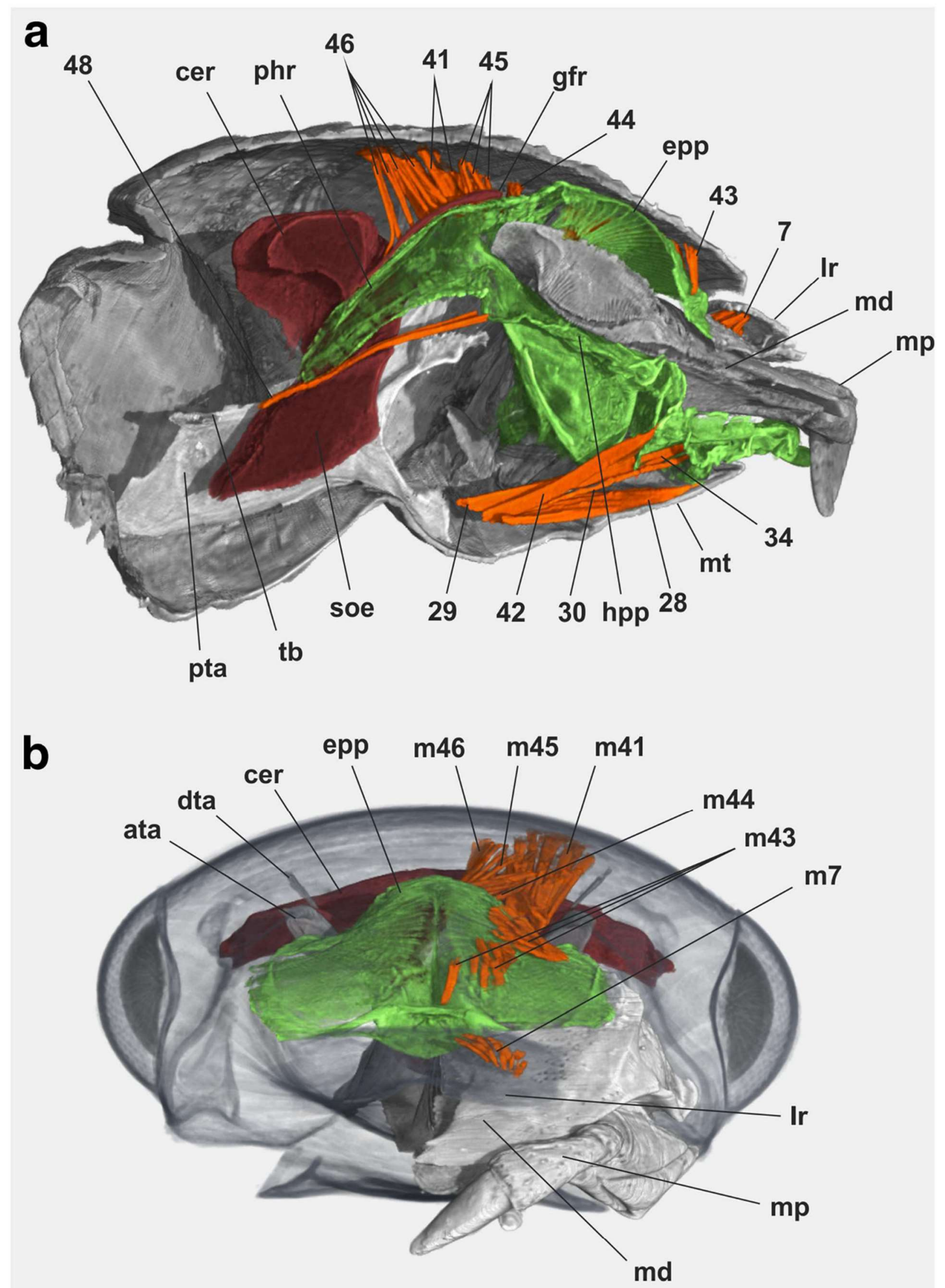

\begin{tabular}{ll} 
muscles labium and digestive tract $\quad$ nervous system \\
\hline
\end{tabular} 


\section{Hypopharynx}

The hypopharynx is firmly connected with the posterior part of the prementum (hpp, Fig. 3j). It is composed of a pair of elongated, posteriorly divergent lobes. The dorsal surface of each of them is densely covered with multiple oblique parallel rows of microtrichia. A conspicuous tuft of erect microtrichia is present medially on the posterior part of the dorsal surface (ht, Fig. 3j). The concave lateral walls of the hypopharynx are sclerotized and medially fused (Fig. 3k).

Musculature: M. frontohypopharyngalis (M41) - (O) large area on posterior frons; (I) large attachment area on posterolateral hypopharyngeal apodeme (Figs. 3k, 4e, f, and 6). M. tentoriohypopharyngalis (M42) - (O) paramedially on the submentum, between origin of M28 and M29; (I) medially on ventral premental strut (Figs. 3k, 4c, and 6a). Additionally, an extrinsic muscle ("Mx" in Jäch et al. 2000; see details in the discussion) of unclear homology (not covered by v. Kéler, 1963) originates from the gena, approximately at the level of the hind edge of the compound eyes (Mx, Fig. 4d, e). It is laterally attached to the membranous area linked to the ventral hyopharyngeal surface.

\section{Pharynx}

The pharynx displays a typical pattern with longitudinal folds for muscle attachment in cross section (phr, Fig. 4f), with a circular to ovoid lumen gradually narrowing towards the posterior cephalic region, before it abruptly expands into a large esophagus. The pharyngeal wall is very thin.

Musculature: M. frontobuccalis anterior (M45)-(O) frons, anterior to M46; (I) dorsolaterally on the precerebral pharynx, anterior to M46 (Figs. 4e and 6). M. frontobuccalis posterior (M46), several bundles-(O) posterior frons; (I) dorsolaterally on precerebral part of the pharynx (Figs. $4 \mathrm{f}$ and 6). M. tentoriobuccalis anterior (M48), long, thin-paired muscle stretching between tritocerebral commissure and subesophageal ganglion - $(\mathrm{O})$ anteromedially on tentorial bridge; (I) medially on ventral margin of the posterior hypopharynx (Figs. 3k, 4e, f, and 6). M. tentoriobuccalis posterior (M50) - (O) tentorial bridge; (I) ventromedially on the anterior pharynx. M. verticopharyngalis (M51)-absent. M. tentoriopharyngalis (M52), three bundles-(O) mesally on gular ridges; (I) ventrolaterally on the posterior pharynx.

\section{Brain and subesophageal ganglion}

The medium-sized brain in the posterodorsal head region does not reach the occipital foramen posteriorly (cer, Figs. $4 \mathrm{f}$ and 6). It lies below the vertex dorsally and is enclosed by M11 laterally, the pharynx ventrally, and M46 anteriorly. The frontal ganglion is well developed (gfr, Figs. $4 \mathrm{f}$ and 6a) and also the frontal connectives and tritocerebral commissure. The subesophageal ganglion fills the entire space between the gula, posterior tentorial arms, and tentorial bridge. Anteriorly, it reaches the laminatentorium (soe, Fig. 6a).

\section{Discussion}

\section{Head capsule, appendages, and labiohypopharyngeal complex}

A series of apparent plesiomorphies documented in Catops had already been identified as typical for microphagous Staphylinoidea, and possible as groundplan features of the entire superfamily (Betz et al. 2003). This includes a cibarial roof with parallel rows of microtrichia corresponding to similar elements on the dorsal molar surface (Fig. 3a), brush-, comb-, or rake-like maxillary structures (Fig. 3c), mandibles with a subapical hyalinous or hairy prostheca and a welldeveloped mola with grinding surfaces (Fig. 3b), and epipharyngeal and hypopharyngeal median tufts of posteriorly directed hairs (Fig. 3i, j). Most of these characteristics were also observed in Myxophaga (Anton and Beutel 2006) and polyphagan groups outside Staphylinoidea (Beutel et al. 2001; Anton and Beutel 2004, 2012; Anton et al. 2016). The basal coleopteran interrelationships revealed in a comprehensive recent study (McKenna et al. 2015b) suggest that a similar configuration may be a groundplan feature of the entire Coleoptera, with independent losses in Adephaga and Archostemata, as previously hypothesized by Beutel et al. (2001). In contrast to the apparently conservative entire complex, some components of the mandibles and maxillae (e.g., prostheca, mandibular apex, retinaculum, galea, lacinia) are very diverse, even between less inclusive taxa such as for instance Leiodidae (e.g., Betz et al. 2003; Moldovan et al. 2004). This variability probably reflects the strong selective pressures involving the paired mouthparts in the context of preferred food material (Betz et al. 2003). The high variability impedes the groundplan reconstruction of these structures for Leiodidae or Cholevinae. Nevertheless, unlike other leiodids, the species studied here is not specialized on a particular food substrate or habitat, which likely represents the plesiomorphic way of life among Cholevinae.

Another noteworthy character confirmed for Catops is the strong constriction of the labiohypopharyngeal complex (Fig. 3k), which occurs at the level of the basal maxillary portion. As a result, the labiohypopharyngeal complex appears hourglass-shaped in cross section. This feature has been found in many other staphyliniform beetles (e.g., Jäch et al. 2000; Beutel et al. 2001; Beutel et al. 2003; Anton and Beutel 2004; Weide and Betz 2009), and more recently in the scarabaeoid Glaresis (Anton and Beutel 2012). The absence in some subordinate taxa such as the leiodine genus 
Agathidium (Weide and Betz 2009) is apparently due to secondary modification. The presence of this derived condition has been postulated as autapomorphy of a clade Staphyliniformia including Scarabaeoidea (Beutel and Leschen 2005), which is equivalent with Staphyliniformia in a narrower sense + Scarabaeoidea as recovered by McKenna et al. (2015a).

Based on molecular data, McKenna et al. (2015a) recovered Leiodidae as monophyletic except for the unexpected position of Colon as sister to Hydraenidae + Ptiliidae. Likewise, Cholevinae was recovered as monophyletic with the exclusion of Afrocatops (Oritocatopini) (McKenna et al. 2015a), and with the exclusion of Eucatops (Eucatopini) in Fresneda et al. (2011). Specific external features documented here for the head of Catops have been considered as potential autapomorphies of Leiodidae (Newton 2016). This includes a five-segmented antennal club with the second club antennomere smaller than the first and third (Fig. 2f), and the presence of periarticular grooves filled with sensilla (Fig. 2h, i) on antennomeres 7, 9, and 10. An unusual derived feature of Cholevinae is the head shape firmly connected to the pronotum with the posterodorsal border of the exposed part of the head abutting the anterior pronotal edge (Fig. 2e). In many species of Leptodirini, however, this characteristic is secondarily modified, presumably as a result of the morphological changes associated to subterranean habits. As described here for Catops (Fig. 2c), a conspicuous genal fold covers the posterior face of the compound eyes in cholevines as a whole, although it has been lost in several eyeless Leptodirini. This trait differentiates Cholevinae from most other leiodids, but a similar condition is found in the head of the few members of Platypsyllinae even though the eyes are missing. The presence of the postocular genal fold in the mentioned groups as well as its occurrence in Hydraenidae (Jäch et al. 2000; Beutel et al. 2003) and within Hydrophiloidea (Beutel 1994; Beutel et al. 2001; Anton and Beutel 2004) probably reflects independent gains.

A set of cryptic pore plates on the preapical and apical maxillary palpomeres of Catops (see detail in Fig. $3 \mathrm{f}$, g) has not been reported before in the literature. These structures are present in many species of Cholevinae, including representatives of the most diverse tribes, such as Anemadini, Cholevini, Ptomaphagini, and Leptodirini (CAC pers. obs.). Similar structures were not found in Eucatopini and Oritocatopini. They are also lacking in outgroup taxa such as in Camiarinae (Agyrtodes), Leiodinae (Colenisia, Decuria, Zeadolopus), Platypsyllinae (Leptinus), and in Agyrtidae (Zeanecrophilus) (CAC pers. obs.). It is uncertain if the pore plates are associated to maxillary glands, since we could not detect any evidence based on the $\mu \mathrm{CT}$ scans. Due to its very small size, the pore plate may have been overlooked in some groups, but based on the available data, it seems to be apomorphic for a group inside the subfamily-i.e., Cholevinae minus Eucatopini and Oritocatopini. The presence of an apical maxillary palpomere shorter than or at most as long as the subapical one, as documented in Catops (Fig. 2c, d), is a derived condition also shared by Cholevinae with the exception of Eucatopini and Oritocatopini, whose apical maxillary palpomere is elongate. As mentioned above, Oritocatopini and Eucatopini have been phylogenetically isolated from the remaining Cholevinae in recent molecular analyses (Fresneda et al. 2011; McKenna et al. 2015a). More data are required to understand their phylogenetic position within Leiodidae.

\section{Tentorium and cephalic musculature}

The internal cephalic structures of Catops are mainly plesiomorphic. The tentorium agrees with the configuration suggested for the groundplan of Staphylinoidea (Weide et al. 2014), formed by paired anterior, dorsal and posterior arms, a fused laminatentorium, and an uninterrupted tentorial bridge. In contrast, in the related leiodid Agathidium and Agyrtidae, the dorsal tentorial arms are missing in the former and the laminatentorium is unfused in the latter (Weide et al. 2014). A laminatentorium is lacking in the highly miniaturized Ptiliidae (Polilov and Beutel 2009).

The pattern of the muscles is similar to what is found in other staphylinoid taxa (e.g., Jäch et al. 2000; Beutel et al. 2003) and is close to the hypothesized groundplan of Staphylinoidea, which according to Weide et al. (2010) is composed by the following muscles: 1, 2, 4, 7, 9, 11, 12, 15, 17-19, Mx, 28-30, 34, 41, 43-46, 48, and 50. The muscle "Mx" was first described in Hydraenidae (Jäch et al. 2000) and later reported in other staphylinoid groups such as Agyrtidae and Staphylinidae (Oxytelinae and Omaliinae: Weide and Betz 2009; Proteininae: Anton and Beutel 2012). It originates on the genal region and inserts on the membranous area between the maxilla and hypopharynx. Whereas it is present in Catops, the muscle was not found in the leiodid Agathidium (Leiodinae, Agathidini) and is apparently also missing in Ptiliidae (Polilov and Beutel 2009) and in the staphylinids Tachyporinae and Aleocharinae (Weide and Betz 2009). The occurrence of "Mx" in Hydrophilidae ("M19a" in Spercheinae: Beutel et al. 2001; "Mx2" in Helophorinae: Anton and Beutel 2004; Hydrochinae: Anton and Beutel 2012) and Sphaeritidae (Anton and Beutel 2012) suggests its presence in the groundplan of Staphyliniformia. However, the recent discovery of a likely homologue in Geotrupidae and Scarabaeidae (named as "M. craniobasimaxillaris" by Anton and Beutel 2012) suggests that this unusual muscle has appeared even earlier in the evolution of beetles, with independent loss in several groups. The presence of "Mx" in the groundplan of Coleoptera can be ruled out as it was not found in Adephaga (Dressler and Beutel 2010), Archostemata (Hörnschemeyer et al. 2002, 2006; Beutel

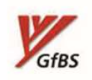


et al. 2008b), and Myxophaga (Anton and Beutel 2006) and is also absent in Dascillidae (Anton and Beutel 2012) and cucujiform taxa (Schneider 1981; Ge et al. 2015). Like the hypopharynx strongly narrowed between the maxillary bases, this is likely a groundplan apomorphy of a clade comprising Staphyliniformia and Scarabaeoidea.

The presence of $M$. frontoepipharyngalis (M9) is ancestral for Coleoptera (e.g., Weide and Betz 2009) and is preserved in the groundplan of Staphylinoidea. However, it is missing in Catops and also in Agathidium (Weide and Betz 2009), in the agyrtid Necrophilus (Weide and Betz 2009), and in the ptiliid Mikado (Polilov and Beutel 2009). A lineage formed by Leiodidae + Agyrtidae together with Hydraenidae + Ptiliidae has been placed as the sister group of the remaining Staphylinoidea (Beutel and Leschen 2005; McKenna et al. 2015a). The presence of $M$. frontoepipharyngalis in Hydraenidae (Jäch et al. 2000; Beutel et al. 2003) shows that it is present in the groundplan of this clade and was apparently reduced two or more times independently.

The presence of $M$. hypopharyngomandibularis (M13) in Cholevinae is apparently a plesiomorphic feature. Its exact point of origin could not be clarified in Catops, but it is inserted medially on the dorsal internal surface of the mandible (Fig. 5a). The muscle was not identified in detailed studies on the head of Adephaga (Dressler and Beutel 2010), Archostemata (Hörnschemeyer et al. 2002, 2006; Beutel et al. 2008b), Myxophaga (Anton and Beutel 2006), and of various lineages of Polyphaga (e.g., Beutel et al. 2003; Weide and Betz 2009; Anton and Beutel 2012; Anton et al. 2016). However, it is documented for Gyrinus and Dermestes (Honomichl 1975, 1976: as M. tentoriomandibularis) and also in Lytta (Schneider 1981) and is therefore very likely ancestral for Coleoptera. It also occurs in many other groups of insects, for instance in the primarily wingless Archaeognatha and Zygentoma (Blanke et al. 2012), in Odonata and Ephemeroptera (Blanke et al. 2012), in polyneopteran orders (Wipfler et al. 2011), and in different groups of Holometabola including the basal Hymenoptera and Mecoptera (Beutel and Vilhelmsen 2007; Beutel et al. 2008a). It is usually extremely thin and may have been overlooked in some studies. Nevertheless, it was apparently reduced several or many times independently in Coleoptera.

Among the staphyliniform beetles hitherto investigated, $M$. tentoriohypopharyngalis (M42) is uniquely present in Catops. It was also identified in Hydraenidae (Hydraena: Jäch et al. 2000; Ochthebius and Limnebius: Beutel et al. 2003) with a submental origin, even though in this case the homology remains disputable. In any case, the presence in Catops is in contrast to the suggested absence in the groundplan of Staphylinoidea (Weide et al. 2010). Moreover, the muscle was also found in Glaresis (Anton and Beutel 2012), a basal representative of Scarabaeoidea (see McKenna et al. 2015a), suggesting its presence in the groundplan of Staphyliniformia + Scarabaeoidea. M. tentoriobuccalis anterior (M48) was misidentified in many studies as M42 (e.g., Beutel et al. 2001; Anton and Beutel 2004, 2006; Weide and Betz 2009), until this issue was clarified in Beutel et al. (2009) and Weide et al. (2010).

\section{Functional interpretation of the feeding apparatus}

C. ventricosus is frequently found in caves or under leaf litter of forested landscapes. They forage on debris derived from different kinds of decaying organic matter such as carrion, dung, or plant material (Salgado 1985; Salgado-Costas and VázquezBlanco 1993; Salgado and Fernández 1998). However, facultative feeding on fungal spores does also occur. The functional configuration of the feeding apparatus is similar to the condition encountered in most other staphylinoids feeding on small particles (see Betz et al. 2003). The robust brush of hairs on the apex of the galea plays a major role in food acquisition, although the distal portion of the lacinia is probably also involved in this function. The interactions between the maxillary endite lobes of both sides transport food substrate towards the upper side of the labiohypopharyngeal complex and the preoral cavity. The mandibles likely support this process, sweeping food particles towards the galeae and laciniae with the dense prosthecal brushes, and presumably also onto the dorsal labiohypopharyngeal surface. In the median region of the transition zone of the dorsal prementum and anterior hypopharynx, an area surrounded by a dense field of microtrichia probably concentrates the collected food particles, which are subsequently transported into the preoral cavity. This process is supported by retraction of the prementum, induced by contractions of M. submentopraementalis (M28), M. tentoriopraementalis inferior (M29), and M. tentoriohypopharyngalis (M42). Grinding takes place between the molar surfaces of the mandibles. The epi- and hypopharyngeal tufts of microtrichia along with the prostheca keep the food particles within the preoral space while the material is processed. Parallel rows of microtrichia on the ventral and dorsal molar surfaces interact with similar elements on the cibarial roof and hypopharynx, respectively, transporting the fine particles towards the anatomical mouth. M. frontohypopharyngalis (M41) probably supports this process by elevating the hypopharynx, thereby narrowing the preoral space and bringing mandibles and hypopharynx in closer contact. In some staphylinids, this process probably results in a trituration of the food substrate by interaction of grinding structures on the ventral molar surface with correspondent structures of the hypopharynx (Weide et al. 2010). This is unlikely in the case of Catops as grinding structures are lacking on the hypopharynx. M. tentoriobuccalis anterior (M.48) is also involved in the transport by retracting the hypopharynx, which supports the shifting of substrate towards the anatomical mouth (Weide et al. 2014). 


\section{Conclusions}

The muscle equipment of the head of Catops is largely plesiomorphic, probably close to the groundplan of Staphyliniformia. Our study shows that most cephalic muscles reported here are shared with other staphylinoid lineages. This suggests that the head anatomy is a rather conserved character system in the evolution of this highly diverse superfamily. The same applies to the general traits of the mouthparts and epiand hypopharynx, mainly characterized by plesiomorphic traits correlated to feeding on small particles. However, Catops also displays typical apomorphic features that define the head of Leiodidae and Cholevinae, such as the interrupted five-segmented antennal club and the characteristic head capsule molded to fit with the anterior pronotal edge, respectively. Catops has been used as an outgroup representative in higher level phylogenetic inferences focused on head characters (e.g., Polilov and Beutel 2009; Beutel et al. 2010; Dressler and Beutel 2010; Randolf et al. 2014), although its cephalic morphology has not yet been documented or described in detail. The present contribution is the first to provide a complete characterization of the head structures of a representative of Cholevinae, offering a broad repertoire of characters potentially useful for future phylogenetic studies. When detailed information on cephalic structures of a broader spectrum of staphylinoid beetles becomes available, the recent molecular phylogeny of McKenna et al. (2015a) will be an excellent framework for tracing the character transformations and reaching a deeper understanding of the evolution of the head in this highly successful superfamily.

Acknowledgments We are grateful to many members of the Entomology Group (Institut für Spezielle Zoologie and Evolutionsbiologie, FSU Jena, Germany) for their assistance in different stages of this work. The $\mu \mathrm{CT}$ data acquisition was arranged by Lars Möckel and Katharina Schneeberg. Benjamin Fabian and David Neubert kindly supported CAC with the use of Amira and VGStudio software. Special thanks go to Dr. Hans Pohl, who kindly provided training and advice on scanning electron microscopy and made available a rotatable specimen holder. We are also very grateful to Arnaud Faille and Javier Fresneda for kindly providing valuable specimens. The $\mu \mathrm{CT}$ scans were taken at DESY (Hamburg, Germany), which is gratefully acknowledged. The $\mathrm{PhD}$ study of $\mathrm{CAC}$ as well as his research internship at the Friedrich-Schiller-Universität was funded by Fundação de Amparo à Pesquisa do Estado de São Paulo (FAPESP) (2012/19002-0 and 2014/22088-0). PG was also supported by FAPESP (2013/06314-7) and MY by the DAAD, which is also gratefully acknowledged. The stay of IR in the Phyletisches Museum in Jena was funded by a Salvador de Madariaga grant (PRX14/00583). The helpful comments of two reviewers are greatly appreciated.

\section{References}

Anton, E., \& Beutel, R. G. (2004). On the head morphology and systematic position of Helophorus (Coleoptera: Hydrophiloidea: Helophoridae). Zoologischer Anzeiger, 242, 313-346.
Anton, E., \& Beutel, R. G. (2006). On the head morphology of Lepiceridae (Coleoptera: Myxophaga) and the systematic position of the family and suborder. European Journal of Entomology, 103, $85-95$.

Anton, E., \& Beutel, R. G. (2012). The adult head morphology of Dascillus (L.) (Dascilloidea: Dascillidae) and Glaresis Erichson (Scarabaeoidea: Glaresidae) and its phylogenetic implications. Arthropod Systematics and Phylogeny, 70(1), 3-42.

Anton, E., Yavorskaya, M. I., \& Beutel, R. G. (2016). The head morphology of Clambidae and its implications for the phylogeny of Scirtoidea (Coleoptera: Polyphaga). Journal of Morphology, 277(5), 615-633.

Beckmann, F., Herzen, J., Haibel, A., Müller, B., \& Schreyer, A. (2008). High density resolution in synchrotron-radiation-based attenuationcontrast microtomography. Proceedings of SPIE, 7078, 70781D. doi:10.1117/12.794617.

Betz, O., Thayer, M. K., \& Newton, A. F. (2003). Comparative morphology and evolutionary pathways of the mouthparts in spore-feeding Staphylinoidea (Coleoptera). Acta Zoologica, 84, 179-238.

Beutel, R. G. (1994). Phylogenetic analysis of Hydrophiloidea (Coleoptera: Polyphaga: Staphyliniformia) based on characters of the head of adults and larvae. Koleopterologische Rundschau, 64, 103-131.

Beutel, R. G., Anton, E., \& Bernhard, D. (2001). Head structures of adults of Spercheus (Coleoptera: Spercheidae): their function and possible significance to staphyliniform phylogeny. Annales Zoologici, 51(4), 473-484.

Beutel, R. G., Anton, E., \& Jäch, M. A. (2003). On the evolution of the adult head structures and the phylogeny of Hydraenidae (Coleoptera, Staphyliniformia). Journal of Zoological Systematics and Evolutionary Research, 41, 256-275.

Beutel, R. G., Friedrich, F., \& Whiting, M. (2008a). Head morphology of Caurinus (Boreidae, Mecoptera) and its phylogenetic implications. Arthropod Structure and Development, 37, 418-433. doi:10.1016/j. asd.2008.02.002.

Beutel, R. G., Ge, S.-Q., \& Hörnschemeyer, T. (2008b). On the head morphology Tetraphalerus, the phylogeny of Archostemata and the basal branching events in Coleoptera. Cladistics, 23, 1-29.

Beutel, R. G., Kristensen, N. P., \& Pohl, H. (2009). Resolving insect phylogeny: The significance of cephalic structures of the Nannomecoptera in understanding endopterygote relationships. Arthropod Structure and Development, 38(5), 427-460. doi:10.1016/j.asd.2009.05.002.

Beutel, R. G., \& Leschen, R. A. B. (2005). Phylogenetic analysis of Staphyliniformia (Coleoptera) based on characters of larvae and adults. Systematic Entomology, 30(4), 510-548. doi:10.1111/ j.1365-3113.2005.00293.x.

Beutel, R. G., \& Molenda, R. (1997). Comparative morphological study of larvae of Staphylinoidea (Coleoptera, Polyphaga) with phylogenetic implications. Zoologischer Anzeiger, 236, 37-67.

Beutel, R. G., \& Vilhelmsen, L. (2007). Head anatomy of Xyelidae (Hexapoda: Hymenoptera) and phylogenetic implications. Organisms, Diversity and Evolution, 7, 207-230. doi:10.1016/j. ode.2006.06.003.

Beutel, R. G., Zimmermann, D., Krauß, M., Randolf, S., \& Wipfler, B. (2010). Head morphology of Osmylus fulvicephalus (Osmylidae, Neuroptera) and its phylogenetic implications. Organisms, Diversity and Evolution, 10, 311-329. doi:10.1007/s13127-0100024-0.

Blanke, A., Wipfler, B., Letsch, H., Koch, M., Beckmann, F., Beutel, R., \& Misof, B. (2012). Revival of Palaeoptera-head characters support a monophyletic origin of Odonata and Ephemeroptera (Insecta). Cladistics, 28(6), 560-581. doi:10.1111/j.1096-0031.2012.00405.x.

Bouchard, P., Bousquet, Y., Davies, A. E., Alonso-Zarazaga, M. A., Lawrence, J. F., Lyal, C. H. C., Newton, A. F., Reid, C. A. M., Schmitt, M., Ślipiński, S. A., \& Smith, A. B. T. (2011). Family- 
group names in Coleoptera (Insecta). ZooKeys, 88, 1-972. doi:10.3897/zookeys.88.807.

Dönges, J. (1954). Der Kopf von Cionus scrophulariae L. (Curculionidae). Zoologische Jahrbücher (Anat.), 74, 1-76.

Dressler, C., \& Beutel, R. G. (2010). The morphology and evolution of the adult head of Adephaga (Insecta: Coleoptera). Arthropod Systematics and Phylogeny, 68(2), 239-287. doi:10.1111/j.10960031.2012.00405.x.

Fresneda, J., Grebennikov, V. V., \& Ribera, I. (2011). The phylogenetic and geographic limits of Leptodirini (Insecta: Coleoptera: Leiodidae: Cholevinae), with a description of Sciaphyes shestakovi sp. n. from the Russian Far East. Arthropod Systematics \& Phylogeny, 69(2), 99-123.

Ge, S.-Q., Hua, Y., Ren, J., Ślipiński, A., Heming, B., Beutel, R. G., Yang, X.-K., \& Wipfler, B. (2015). Transformation of head structures during the metamorphosis of Chrysomela populi (Coleoptera, Chrysomelidae). Arthropod Systematics and Phylogeny, 73(1), 129 152.

Greving, I., Wilde, F., Ogurreck, M., Herzen, J., Hammel, J. U., Hipp, A., Friedrich, F., Lottermoser, L., Dose, T., Burmester, H., et al. (2014). P05 imaging beamline at PETRA III: first results. Proceedings of SPIE 9212, Developments in X-Ray Tomography IX, 921200.

Honomichl, K. (1975). Beitrag zur Morphologie des Kopfes der Imago von Gyrinus substriatus Stephens, 1829 (Coleoptera, Insecta). Zoologische Jahrbücher (Anat.), 94, 218-295.

Honomichl, K. (1976). Feinstruktur eines Muskelrezeptors im Kopf von Dermestes maculatus De Geer (Insecta, Coleoptera). Zoomorphology, 85, 59-71.

Hörnschemeyer, T., Beutel, R. G., \& Pasop, F. (2002). Head structures of Priacma serrata Leconte (Coleoptera, Archostemata) inferred from X-ray tomography. Journal of Morphology, 252, 298-314.

Hörnschemeyer, T., Goebbels, J., Weidemann, G., Faber, C., \& Haase, A. (2006). The head morphology of Ascioplaga mimeta (Coleoptera: Archostemata) and the phylogeny of Archostemata. European Journal of Entomology, 103, 409-423.

Huesman, R., Gullberg, G., Greenberg, W., \& Budinger, T. F. (1977). RECLBL Library users manual: Donner algorithms for reconstruction tomography. Livermore: Lawrence Berkeley Laboratory, University of California.

Jäch, M. A., Beutel, R. G., Díaz, J. A., \& Kodada, J. (2000). Subgeneric classification, description of head structures, and world check list of Hydraena Kugelann (Insecta: Coleoptera: Hydraenidae). Annalen des Naturhistorischen Museums Wien, 102B, 177-258.

Lawrence, J. F., Ślipiński, A., Seago, A. E., Thayer, M. K., Newton, A. F., \& Marvaldi, A. E. (2011). Phylogeny of the Coleoptera based on morphological characters of adults and larvae. Annales Zoologici, 61(1), 1-217. doi:10.3161/000345411X576725.

McKenna, D. D., Farrell, B. D., Caterino, M. S., Farnum, C. W., Hawks, D. C., Maddison, D. R., Seago, A. E., Short, E. Z., Newton, A. F., \& Thayer, M. K. (2015a). Phylogeny and evolution of Staphyliniformia and Scarabaeiformia: forest litter as a stepping stone for diversification of nonphytophagous beetles. Systematic Entomology, 40(1), 35-60. doi:10.1111/syen.12093.

McKenna, D. D., Wild, A. L., Kanda, K., Bellamy, C. L., Beutel, R. G., Caterino, M. S., Farnum, C. W., Hawks, D. C., Ivie, M. A., Jameson, M. L., Leschen, R. A. B., Marvaldi, A. E., Mchugh, J. V., Newton, A. F., Robertson, J. A., Thayer, M. K., Whiting, M. F., Lawrence, J. F., Ślipiński, A., Maddison, D. R., \& Farrell, B. D. (2015b). The beetle tree of life reveals that Coleoptera survived end-Permian mass extinction to diversify during the Cretaceous terrestrial revolution. Systematic Entomology, 40(4), 835-880. doi:10.1111/syen.12132.
Moldovan, O. T., Jalžić, B., \& Erichsen, E. (2004). Adaptation of the mouthparts in some subterranean Cholevinae (Coleoptera, Leiodidae). Natura Croatica, 13(1), 1-18.

Newton, A. F. (1998). Phylogenetic problems, current classification and generic catalog of World Leiodidae (including Cholevidae). Museo Regionale di Scienze Naturali di Torino Atti, 8, 41-177.

Newton, A. F. (2016). Leiodidae Fleming, 1821. In R. G. Beutel \& R. A. B. Leschen (Eds.), Handbook of Zoology, Vol. IV, Arthropoda: Insecta; Coleoptera, Morphology and Systematics (Archostemata, Adephaga, Myxophaga, Polyphaga partim), Vol. 1 (2nd ed., pp. 364-376). Berlin and New York: Walter De Gruyter.

Perreau, M. (2000). Catalogue des Coléoptères Leiodidae Cholevinae et Platypsyllinae. Memoires de la Societé Entomologique de France, 4, $1-460$.

Pohl, H. (2010). A scanning electron microscopy specimen holder for viewing different angles of a single specimen. Microscopy Research and Technique, 73(12), 1073-1076. doi:10.1002/jemt.20835.

Polilov, A. A., \& Beutel, R. G. (2009). Miniaturisation effects in larvae and adults of Mikado sp. (Coleoptera: Ptiliidae), one of the smallest free-living insects. Arthropod Structure and Development, 38, 247270. doi:10.1016/j.asd.2008.11.003.

Randolf, S., Zimmermann, D., \& Aspöck, U. (2014). Head anatomy of adult Nevrorthus apatelios and basal splitting events in Neuroptera (Neuroptera:Nevrorthidae). Arthropod Systematics \& Phylogeny, $72(2), 111-136$.

Salgado, J. M. (1985). Nuevos datos sobre Catopidae (Col.) capturados en cuevas. Boletín de la Asociación española de Entomología, 9, 271-277.

Salgado, J. M., \& Fernández, M. (1998). Estudio de los Leiodidae: Cholevinae (Coleoptera) en las cuencas de los ríos Bernesga, Torío y Porma (León, España). Boletín de la Asociación española de Entomología, 22(1-2), 81-97.

Salgado-Costas, J. M., \& Vázquez-Blanco, M. G. (1993). Estudio de los Carábidos y Colévidos (Coleoptera) de Cueva Rosa (Asturias, España). Boletín de la Asociación española de Entomología, 17(1), 131-142.

Schneider, W. (1981). Zur Kopfmorphologie der Imago des Ölkäfers Lytta vesicatora (Coleoptera: Meloidea). Entomologica Generalis, $7(1), 69-87$.

von Kéler, S. (1963). Entomologisches Wörterbuch. Berlin: Akademie Verlag.

Weide, D., \& Betz, O. (2009). Head morphology of selected Staphylinoidea (Coleoptera: Staphyliniformia) with an evaluation of possible groundplan features in Staphylinidae. Journal of Morphology, 270, 1503-1523. doi:10.1002/jmor.10773.

Weide, D., Thayer, M. K., \& Betz, O. (2014). Comparative morphology of the tentorium and hypopharyngeal-premental sclerites in sporophagous and non-sporophagous adult Aleocharinae (Coleoptera: Staphylinidae). Acta Zoologica, 95, 84-110. doi:10.1111/azo.12011.

Weide, D., Thayer, M., Newton, A. F., \& Betz, O. (2010). Comparative morphology of the head of selected sporophagous and nonsporophagous Aleocharinae (Coleoptera: Staphylinidae): musculature and hypopharynx-prementum complex. Journal of Morphology, 271, 910-931.

Wipfler, B., Machida, R., Müller, B., \& Beutel, R. (2011). On the head morphology of Grylloblattodea (Insecta) and the systematic position of the order, with a new nomenclature for the head muscles of Dicondylia. Systematic Entomology, 36, 241-266. doi:10.1111/ j.1365-3113.2010.00556.x. 
CAPÍTULO 3 



\section{Morphology-based phylogenetic reconstruction of Cholevinae (Coleoptera:}

Leiodidae) - a new view on higher-level relationships

Caio Antunes-Carvalho ${ }^{\mathrm{a},}{ }^{*}$, Ignacio Ribera ${ }^{\mathrm{b}}$, Rolf Georg Beutel ${ }^{\mathrm{c}}$ and Pedro Gnaspini ${ }^{\mathrm{a}}$

${ }^{a}$ Departamento de Zoologia, Instituto de Biociências, Universidade de São Paulo, Rua do Matão, Travessa 14, 101, 05508-090 São Paulo, SP, Brazil

${ }^{b}$ Instituto de Biología Evolutiva (CSIC-Universitat Pompen Fabra), Passeig Maritim de la Barceloneta 37-49, 08003 Barcelona, Spain

${ }^{c}$ Entomology Group, Institut für Spezielle Zoologie und Evolutionsbiologie mit Phyletischem Museum, FSU Jena, Erbertstrasse 1, 07743 Jena, Germany

* Corresponding author: Caio Antunes-Carvalho, Departamento de Zoologia, Instituto de Biociências, Universidade de São Paulo, Rua do Matão, Travessa 14, 101, 05508-090 São Paulo, SP, Brazil. E-mail address: cantunescarvalho@gmail.com 



\begin{abstract}
A robust cladistic assessment explicitly focused on Cholevinae has never been performed. The current state of knowledge on the suprageneric relationships within the subfamily is either derived from informal evaluations of putative synapomorphies or based on molecular studies of limited taxonomic sampling. We assessed the higher-level relationships of Cholevinae based on a phylogenetic analysis of 97 morphological characters in 93 terminals, representing all tribes. Both parsimony and Bayesian analyses were used in phylogenetic reconstruction. The monophyletic origin of Cholevinae was corroborated, save for the unexpected inclusion of Leptinus in the implied weighting analysis. In contrast to other studies, Eucatopini + Oritocatopini were retrieved as basal branches in the evolution of Cholevinae. The monophyletic origin of all remaining tribes was confirmed, which is congruent with molecular evidence. Anemadini turned out as non-monophyletic, in accordance with earlier hypotheses. Cholevini was rendered non-monophyletic by the uncertain inclusion of Prionochaeta and the consistent exclusion of Cholevinus. The affinity of Ptomaphagini with Sciaphyini and Leptodirini was suggested, even though the position of Sciaphyes is still not precisely defined. Nemadina was invariably associated to these tribes, and Eocatopina was consistently recovered as the sister taxa of this clade involving the three tribes plus Nemadina. The phylogenetic hypothesis of Cholevinae provided here is the most comprehensive one presently available. For the first time an extensive set of morphological characters was scored for a broad taxon sampling and analysed with different approaches. The list of characters shows that substantial part of the data was obtained from the ventral side. This is a strong argument for increasing detailed pictorial documentation of the ventral view in taxonomic descriptions, in contrast to the common practice of only illustrating the dorsal habitus of these beetles.
\end{abstract}





\section{Introduction}

With more than 4,100 described species (Newton, 2016) and a worldwide distribution, the staphyliniform family Leiodidae has the second highest species diversity within the megadiverse Staphylinoidea. The eclectic repertoire of habitats and food sources potentially utilized by these beetles is impressive, and difficult to synthesize concisely. According to Newton (2016), however, most leiodids might fit into one of three broad categories: (i) ground-dwelling saprophages or general scavengers of forest leaf litter, deep soil or cave environments; (ii) saprophagous inhabitants of carrion, dung and equivalent concentrated decaying organic matter; or (iii) obligate mycophages relying on various groups of fungi. Some species inhabit nests of social insects including ants, wasps, termites and stingless bees (Jeannel, 1936; Peck and Cook, 2002; Peck, 2003; Peck and Cook, 2007), while others may be found in nests or burrows of reptiles (e.g. tortoises), birds (e.g. owls) and mammals (e.g. foxes, moles, shrews and various rodents) (Jeannel, 1936; Newton, 1998; Peck and Skelley, 2001; Guéorguiev and Bekchiev, 2009). There are still a few highly modified ectoparasite species of aquatic or semiaquatic mammals (Peck, 1982).

Leiodidae is presently subdivided into six subfamilies. Cholevinae and Leiodinae - informally called small carrion beetles and round fungus beetles respectively - are by far the most species-rich, with representatives in both tropical and temperate regions. Cholevinae, the most diverse, comprises ca. 2,050 species arranged in seven tribes and 17 subtribes (Perreau, 2000; Bouchard et al., 2011). The geographic limits of these subgroups vary substantially: while the monogeneric Sciaphyini is only known from a few localities in the East Palearctic region, Anemadini may be found in the Holarctic, Neotropical, Oriental, Australotropical, Australotemperate, Neoguinean, Neozelandic and Andean regions (Newton, 2016), and the highly speciose Leptodirini is mainly restricted to the western Palaearctic, with its greatest diversity found in the north Mediterranean basin (Perreau, 2004; Fresneda et al., 2011). Although not very appealing from an aesthetic perspective (except for the strongly modified cave-adapted leptodirines), cholevine beetles arguably offer a broad array of attractive topics in evolutionary biology, ecology and biogeography.

Intensive investigations were devoted to the taxonomy of both Leiodidae and Cholevinae in the last decade. Among 674 leiodid species described since 2005, 255 were cholevines (see Newton 2005, 2016). However, these efforts were not paralleled by phylogenetic studies. A robust cladistic assessment explicitly focused on Leiodidae or Cholevinae has never been performed. Within this scenario of limited phylogenetic insights, the molecular analyses of Fresneda et al. (2011) and McKenna et al. (2015) are of great importance, even though these studies were not explicitly designed to investigate the internal relationships throughout Cholevinae or Leiodidae. The study of McKenna et al. (2015) constitutes a large-scale analysis aiming at the phylogeny of Staphyliniformia, and only 
included about a dozen of selected cholevine representatives. The molecular phylogeny in Fresneda et al. (2011) is the largest for Cholevinae and tentatively shed some light on its internal relationships. However, since it was targeted at Leptodirini, some cholevine subgroups were not sampled, especially from south temperate faunas.

Whereas the monophyly of Cholevinae was not recovered by Fresneda et al. (2011) and McKenna et al. (2015), this subfamily has been considered as a natural unit by Newton $(1998,2016)$ based on an informal evaluation of putative synapomorphies. Therefore, the higher level classification of Cholevinae remains an important area of investigation. The aim of the present study was to test the monophyly of Cholevinae on the basis of phylogenetic analysis and propose a hypothesis for the higher-level relationships in the subfamily, based on the broadest taxonomic sampling ever conducted.

\section{Material and methods}

\section{Morphological study and taxonomic sampling}

Ninety-seven characters were scored from adult morphology of 93 terminal taxa, mainly using scanning electron microscopy (SEM). Studied character systems were the head, prosternum, mesoand metaventrite, elytra, legs including the pretarsus and distal margin of the terminal tarsomere, and the abdomen including the aedeagus (the latter mainly based on data obtained from published descriptions). The ingroup included representatives of all currently recognized cholevine tribes and subtribes, with the exception of Baryodirina, a monotypic subtribe proposed based on a single female of Baryodirus (Perreau, 2000). This genus, however, was included in the matrix and its characters were coded based on the SEM images of Baryodirus provided in the original description of the taxon (Perreau, 2000: figs 1-10). The limited information content of the images concerning the characters utilized here, in addition to the lack of data on males, resulted in a high number of missing entries ( $46 \%$ ). We therefore assessed the position of Baryodirus employing an additional, separate analysis.

Twelve outgroup taxa were selected from 4 of the 5 non-cholevine subfamilies of Leiodidae (representing 10 out of 11 non-cholevinae tribes) - Camiarinae: Agyrtodes labralis and Eupelates transversestrigosus (Agyrtodini), Camiarus thoracicus (Camiarini), and Neopelatops edwarsi (Neopelatopini); Catopocerinae: Catopocerus politus (Catopocerini); Leiodinae: Colenisia zelandica (Pseudoliodini), Decuria sp. (Agathidiini), Dietta huanuco (Estadiini), Hydnodiaetus sp. (Sogdini), Scotocryptus sp. (Scotocryptini), and Zeadolopus validipes (Leiodini); and Platypsyllinae: Leptinus testaceus. Only Coloninae (with 2 genera) and the monotypic Glacicavicolini (Catopocerinae) are not represented. Several cladistic studies both based on molecules and morphology have consistently placed Agyrtidae as the sister-taxon of Leiodidae (e.g. Beutel and Molenda 1997, Beutel and Leschen, 
2005; Caterino et al., 2005; McKenna et al., 2015), corroborating the hypothesis of previous taxonomic studies (e.g. Newton, 1997, 1998). The agyrtid Zeanecrophilus prolongatus was then used to root the tree. Most species used in the present study belong to museums or were obtained from private collections. The list of species we examined, their systematic assignment and authorities, are provided in Table 1. Most terminal taxa represent single species. Only in three cases the terminal taxon was scored based on two different congeneric species: Anthroherpon hoermanni + A. primitivum; Prionochaeta harmandi + P. opaca; Platycholeus leptinoides $+P$. opacellus. It is assumed that these species are more closely related to one another than to any other terminal in the matrix. The character matrix is shown in Appendix 1.

\section{Pictorial documentation}

Both dried and alcohol-preserved specimens were examined and documented using SEM. Dissected body parts were immersed in contact lens solution for $24 \mathrm{~h}$ to clean the tegumentary structures and then dehydrated in an ethanol series of increasing concentration, air-dried or stove-dried, sputtercoated with gold (Emitech K 500, Sample preparation division, Quorum Technologies Ltd., Ashford, England), and fixed on a rotatable specimen holder (Pohl, 2010). Most images were taken with an ESEM XL30 (Philips, Amsterdam, Netherlands) equipped with Scandium FIVE (Olympus, Münster, Germany), but some data were also obtained with a Zeiss DSM 940 (Carl Zeiss AG, Oberkochen, Germany) scanning electron microscope using conventional stubs. Additional morphological observations and documentation were conducted using a Zeiss Discovery V20 stereomicroscope equipped with an AxioCam MRc5 digital camera (Carl Zeiss AG, Oberkochen, Germany).

\section{Classification system and terminology}

The suprageneric classification of Leiodidae is based on Newton (1998), Perreau (2000) and Bouchard et al. (2011). At species level, we followed Perreau (2000, 2004). Most of the morphological terms used here are based on Lawrence et al. $(2010,2011)$. Terms related to the morphology of the pretarsus and distal margin of the terminal tarsomere follow Antunes-Carvalho and Gnaspini (2016).

\section{Cladistic analysis}

The data matrix was compiled using MESQUITE 3.10 (Maddison and Maddison, 2016) and analyzed under parsimony with TNT v. 1.1 (Goloboff et al., 2008b). Heuristic searches were performed under both equal and implied weighting (Goloboff, 1993; Goloboff et al., 2008a) using the New Technology algorithms with the following parameters: sectorial search (Goloboff, 1999) in default mode, 200 iteractions of ratchet (Nixon, 1999), 20 cycles of drift (Goloboff, 1999), and 10 rounds of tree fusing 
(Goloboff, 1999). This procedure was repeated until the best score was located 100 times. The TNT setk script, developed by Salvador Arias, was used to identify the most appropriate K value through the formula proposed by Goloboff et al. (2008a). A value of 14.7852 was returned and subsequently employed in the implied weighting scheme. Nodes were evaluated with Bremer supports (Bremer, 1994) with the Bremer.run script supplied by TNT, and symmetric resampling (Goloboff et al., 2003) expressed as the difference in the CG (contradicted/present groups) frequency (1000 replications). Optimizations were performed with Winclada-ASADO 1.62 (Nixon, 2002). Only unambiguous changes were mapped on the tree. We coded most characters as binary $(88.7 \%)$ and treated the multistate as unordered. Parsimony-uninformative characters were deactivated before analysis and therefore do not contribute to tree length nor to other statistics. However, they were optimized onto the tree and were included in the character list and data matrix because they may be of interest for future research.

\section{Bayesian analysis}

Bayesian analysis was conducted with MrBayes 3.2 (Ronquist and Huelsenbeck, 2003) using the Mkv model (Lewis, 2001) with a single partition. Two separate runs were conducted, each with one cold and three heated chains, checking for adequate mixing with the statistics provided by the program. To assess convergence and establishing a burn-in fraction, we initially set the analyses to run for an overestimated $25 \times 10^{\wedge} 6$ generations, sampled every 1,000 . We then assessed convergence by visual examination of a plot of the standard deviation of the split frequencies between the two simultaneous runs, establishing the burn-in when it reached estable values at ca. 0.005 . Once the burn-in was fixed, we let the analyses run until the effective sample size (ESS) reached values above 200 as estimated in Tracer v1.5 (Rambaut and Drummond, 2007), considered to be sufficient for a good sampling of the post-burn-in tree space (Rambaut and Drummond, 2007). The resulting trees were combined in a majority rule consensus topology with posterior probability (pp) of nodes calculated using the sumt command in MrBayes.

\section{Results}

External and internal characters were scored for 13 outgroup taxa and 80 ingroup terminals covering all tribes and 16 of the 17 subtribes in Cholevinae. The complete data set comprised 23 characters of the head, six of the prosternum, 22 of the meso- and metaventrite, seven of the elytra, five of the tarsus and tibial spurs, 28 of the pretarsus and distal margin of the terminal tarsomere, one of the abdomen and five of the male genitalia. Characters 82, 91 and 92 were parsimony-uninformative (autapomorphies of Ptomaphaminus, Leptinus and Sciaphyes, respectively). Traits potentially strongly 
affected by convergent evolution induced by adaptations to underground life were avoided (e.g. absence of eyes and posterior wings).

\section{List of characters}

Head

1. Cuticular surface of gula: (0) reticulated (Fig. 1a); (1) smooth (Fig. 1b).

2. Hypostomal suture: (0) present, even if very weak (Fig. 1c: hs); (1) absent (Fig. 1d).

3. Postmandibular ridge: (0) present (Fig. 1e: pmr); (1) absent (Fig. 1f).

4. Area close to anterior margin of mentum: (0) flat (Fig. 1g); (1) with recognizable low, transverse ridge (Fig. 1h: arm).

5. Lateral margin of mentum: (0) without longitudinal ridge (Fig. 1h); (1) with longitudinal ridge (Fig. 1g: $1 \mathrm{rm})$.

6. Ventral surface of prementum (ventral view): (0) without macrosetae (Fig. 2a); (1) with a single macroseta on left side (Fig. 2c); (2) with a single macroseta on right side (Fig. 2d); (3) paramedian pair of macrosetae (Fig. 2b).

7. Apical labial palpomere: (0) without lateral peg-like sensilla (Fig. 2e); (1) with lateral peg-like sensilla (Fig. 2f).

8. Size of apical maxillary palpomere: (0) distinctly longer than preapical palpomere (Fig. 2g, i); (1) not longer than preapical palpomere (Fig. 2h, j).

9. Shape of apical maxillary palpomere: (0) subcylindrical, diameter subequal from base to apex (Fig. 2g); (1) conical (Fig. 2h); (2) subcylindrical and distinctly narrowed just after its base (Fig. 2j); (3) strongly expanded (only Camiarus; Fig. 2i).

10. Sensilla of apical maxillary palpomere: (0) digitiform sensilla (i.e. sensilla adpressed to surface; Fig. 3a: dgts); (1) projecting sensilla (i.e. sensilla articulated to surface; Fig. 3b, c: ps).

11. Vestiture of apical maxillary palpomere: (0) mostly glabrous (Fig. 2j); (1) pubescent (e.g. Figs 2gi and 3).

12. Pore plates on the subapical maxillary palpomere: (0) absent; (1) present (Fig. 4).

13. Setal pits on vertex: (0) without areola (Fig. 5d); (1) with areola (Fig. 5c: sa).

14. Microsculpture of central area of the frontoclypeal surface: (0) with weak irregular strioles (Fig. 5a); (1) with transverse strigae (Fig. 5b); (2) with fine microreticulation (Fig. 5c); (3) smooth (Fig. 5d).

15. Dorsal surface: (0) mostly glabrous (Fig. 5e); (1) pubescent (Fig. 5f). 
16. Anterior margin of clypeus: (0) not delimited by ridge (Fig. 6a); (1) delimited by ridge (Fig. 6b: arc).

17. Anterior portion of clypeus: (0) not truncate (Fig. 6c); (1) truncate (Fig. 6d).

18. Frontoclypeal strengthening ridge: (0) visible externally (at least laterally, may be weakly impressed) (Fig. 6c: fsr); (1) not visible (Fig. 6d).

19. Head shape: (0) without transverse border abutting the anterior pronotal edge (Fig. 6e); (1) with transverse border abutting the anterior pronotal edge (Fig. 6f).

20. Elevated transverse occipital ridge: (0) absent (Fig. 6g); (1) present (Figs 6h, 7b: or).

21. Posterior face of compound eye: (0) not covered by genal fold, head not abruptly narrowed immediately behind eyes (Fig. 7a); (1) covered by genal fold, head abruptly narrowed immediately behind eyes (Figs 6h, 7b: pogf).

22. Antennal insertion: (0) visible from above (Fig. 7d); (1) not visible from above (Fig. 7c).

23. Size of the second antennomere of club relative to the first and third: (0) subequal; (1) smaller (e.g. Newton, 1998: fig. 7).

\section{Prosternum}

24. Area anterior to procoxal cavities: (0) large (Fig. 8a); (1) strongly shortened (Fig. 8b, c).

25. Ventrally directed plate: (0) absent (Fig. 8a); (1) present (Fig. 8b: vdp).

26. Procoxal cavities: (0) open posteriorly (Fig. 8a); (1) closed posteriorly (Fig. 8b, c).

27. Postcoxal projection of hypomeron (pph): (0) acute (Fig. 8b); (1) broadly rounded or blunt (Fig. $8 \mathrm{c})$.

28. Lateral opening of procoxal cavity: (0) horizontal (Fig. 8c: lopc); (1) oblique (i.e. pointing anterolaterad; Fig. 8b).

29. Posterior margin of prosternal process: (0) without medial notch (Fig. 8c); (1) with acute, short medial notch (Fig. 8b: mnp). Not applicable if procoxal cavity is open posteriorly $(\mathrm{Ch} 26(0))$.

\section{Meso- and metaventrite}

30. Suture between mesanepisternum (mset) and mesoventrite (msv): (0) visible externally on the cuticular surface (e.g. Fig. 9a, c, d); (1) not visible externally on the cuticular surface (Fig. 9b).

31. Suture between mesanepisternum (mset) and mesoventrite (msv): (0) complete (e.g. Fig. 9a, c, d); (1) incomplete (Fig. 9e, f). Not applicable if the suture is not visible on the cuticular surface (Ch 30(1)).

32. Suture between mesanepisternum (mset) and mesepimeron (msp): (0) visible externally on the cuticular surface (e.g. Fig. 9c, e); (1) not visible externally on the cuticular surface (Fig. 9a, b, d).

33. Suture between mesanepisternum (mset) and mesepimeron (msp): (0) oblique (i.e. pointing anterolaterad; Fig. 9c, f); (1) approximately horizontal (Fig. 9e). Not applicable if the suture is not 
visible externally on the cuticle (Ch32(1)).

34. Posterolateral edge of mesepimeron (msp): (0) not projecting posteriad; posterior margin of mesepimeron mainly straight (Fig. 9d); (1) projecting posteriad, leading to a slightly concave posterior margin of the mesepimeron (Fig. 9f).

35. Posteromesal corner of mesepimeron (msp): (0) not forming acute angle (Fig. 11a); (1) forming distinct acute angle (Fig. 11b: pcm).

36. Posterior margin of mesepimeron (msp): (0) single, not bifurcated (Fig. 9e); (1) bifurcated, resulting in two diverging lines (Fig. 9f).

37. Anterior edge of mesoventrite (msv) at midline (Lawrence et al., 2011: Ch163): (0) approximately on same plane as metaventrite (i.e. mesoventral process not projecting ventrad; e.g. Fig. 9); (1) on a distinctly different plane than metaventrite (i.e. mesoventral process projecting ventrad; Fig. 10a).

38. Median longitudinal carina (i.e. mesoventral keel): (0) absent (e.g. Figs 9c, d); (1) present (e.g. Fig. 9e, f: mlc).

39. Mesocoxal cavities: (0) separated (e.g. Figs 9a, e, 11b); (1) contiguous (Figs 9c, d, 11a).

40. Mesoventral process: (0) extending approximately to middle of mesocoxae (e.g. Fig. 9a); (1) extending beyond middle region of mesocoxae, not reaching posterior edge of mesocoxal cavities (e.g. Fig. 9e); (2) extending beyond posterior edge of mesocoxal cavities but not reaching midlength of metaventrite; (3) extending to or beyond midlength of metaventrite (Fig. 11b). Not applicable if the mesocoxal cavities are contiguous (Ch39(1)) or if the mesoventral process is completely fused to the metaventral process or metaventrite (41(3)).

41. Mesoventral and metaventral processes (modified from Lawrence et al., 2011: Ch184): (0) overlapping with metaventrite ventrad of mesoventrite (e.g. Figs 9a and 10b); (1) meeting at point or abutting; (2) solidly fused but with a visible suture or line between them (Fig. 10a); (3) solidly fused without visible suture or line. Not applicable if the mesocoxal cavities are contiguous (Ch39(1)).

42. Mesocoxal cavities (modified from Lawrence et al., 2011: Ch180): (0) contiguous or separated by up to $1 / 4$ of shortest diameter of coxal cavity (Fig. 9); (1) separated by more than $3 / 4$ shortest diameter of coxal cavity (Fig. 10a).

43. Apex of mesoventral process (modified from Lawrence et al., 2011: Ch173): (0) acute or rounded (e.g. Figs 9a, e, and 10b); (1) truncate (Fig. 10a). Not applicable if the mesoventral process is fused to the metaventral process or metaventrite (Ch41(3)).

44. Line of impressions posterior to mesocoxal cavities: (0) absent (e.g. Fig. 10a); (1) present (Fig. 10b).

45. Transverse line of metaventrite anterior to metacoxal cavity: (0) present (e.g. Fig. 9b, c); (1) absent (e.g. Fig. 9a).

46. Posterior edge of mesocoxal cavity: (0) with about the same width (e.g. Fig. 9a-e); (1) with a clear widening (short or long; Figs 9f and 11). 
47. Metanepisternum (mtet): (0) easily visible from ventral view (i.e. anapleural suture [as] clearly visible; e.g. Fig. 9b-e); (1) very slender or not visible (i.e. anapleural suture not clear or located close to the anterolateral and lateral edge of the metaventrite; e.g. Fig. 9f).

48. Metaventral carina originating at lateral edge of mesocoxal cavity (Gnaspini, 1996: Ch 1): (0) absent (e.g. Fig. 9a-d); (1) present (Fig. 9e: mc). This character is possibly associated to character 46. The condition found in Notidocharis, Pseudoboldoria, Quaestus (Fig. 11b), Breuilia, Platycholeus, and Sciaphyes is coded as 1 in both characters (46 and 48).

49. Metaventral process (mtvp): (0) bifid (e.g. Fig. 9f); (1) single (e.g. Fig. 9e).

50. Metaventral fovea: (0) absent; (1) present.

51. Metaventral longitudinal carina: (0) absent; (1) present (e.g. Fresneda et al., 2011: fig. 24).

Elytra

52. Parasutural stria: (0) absent; (1) present.

53. Dorsal surface: (0) with longitudinal striae impressed and punctate (Fig. 12a, e); (1) with longitudinal striae punctate (Fig. 12b, f); (2) with transverse striolations (Fig. 12c, g); (3) without distinct striae or striolations (Fig. 12d, h).

54. Pubescence: (0) glabrous or with scattered short setae (Fig. 12a, b); (1) densely pubescent (Fig. $12 \mathrm{c}, \mathrm{d})$.

55. Minute setae: (0) absent (e.g. Fig. 13d-f); (1) present (e.g. Fig. 13a-c).

56. Distribution of minute setae: (0) irregular (Fig. 13c); (1) arranged in transverse lines (e.g. Fig. 13a, b). Not applicable if the minute setae are absent $(\mathrm{Ch} 55(0))$.

57. Minute spine-like cuticular protuberances: (0) absent (e.g. Fig. 13a, d); (1) present (Fig. 13e).

58. Dorsal surface: (0) smooth (e.g. Fig.13d); (1) microsculptured (e.g. Fig. 13e, f).

Legs

59. Number of protarsomeres in the female (Fresneda et al., 2011: Ch11): (0) five; (1) four; (2) three.

60. Mesotarsus of male (modified from Fresneda et al., 2011: Ch 12): (0) expanded (Fig. 14a); (1) not expanded (Fig. 14b).

61. Meso- and metatibial ventral spurs (modified from Fresneda et al., 2011: Ch 13): (0) simple (Fig. 15a-c); (1) pectinate or multi-toothed laterally (Fig. 15d-i).

62. Surface of meso- and metatibial ventral spurs: (0) devoid of spines (e.g. Fig. 15a, f, g, i); (1) densely covered by spines (Fig. 15d, e).

63. Pore plates on terminal tarsomere: (0) absent; (1) present (Fig. 16). Present on cuticular surface of terminal tarsomere of several species of Leptodirini.

Pretarsus and distal margin of the terminal tarsomere 
64. Medial projection of terminal protarsomere (modified from Antunes-Carvalho and Gnaspini, 2016: Ch1): (0) weak (Fig. 17a); (1) trapezoid/triangular (e.g. Fig. 17b); (2) paired (e.g. Fig. 17c: mpp).

65. Oblique row of spines (rsmp) of medial projection of terminal protarsomere (Antunes-Carvalho and Gnaspini, 2016: Ch2): (0) absent (e.g. Fig. 17a, c); (1) present (Fig. 17b: rsmp).

66. Medial projection of terminal meso- and metatarsomere (modified from Antunes-Carvalho and Gnaspini, 2015: Ch1): (0) weak; (1) trapezoid/triangular; (2) paired (mpp).

67. Oblique row of spines (rsmp) of medial projection of terminal mesotarsomere: (0) absent; (1) present.

68. Oblique row of spines (rsmp) of medial projection of terminal metatarsomere: (0) absent; (1) present.

69. Spine-like projection close to lateral margin of terminal meso- and metatarsomere (AntunesCarvalho and Gnaspini, 2016: Ch3): (0) absent (e.g. Fig. 19); (1) present (Fig. 18b: slp).

70. Dorsal flattened seta in the distal margin of terminal protarsomere: (0) absent; (1) present. Only present in the species of Paulipalpina (see Antunes-Carvalho and Gnaspini, 2016: fig. 9H: dfs).

71. V-shaped depression at distal extension of unguitractor plate (Antunes-Carvalho and Gnaspini, 2016: Ch4): (0) absent (e.g. Fig. 19b); (1) present (Fig. 19a).

72. Tuft of setae of empodium: (0) absent; (1) present. A tuft of setae is only present on the empodium of the species of Paulipalpina (see Antunes-Carvalho and Gnaspini, 2016: fig. 9J: tf).

73. Median sclerite (ms, Antunes-Carvalho and Gnaspini, 2016: Ch5): (0) not incised medially (e.g. Fig. 20a, b); (1) divided by median incisure (Fig. 20c-e).

74. Ventral projection of empodial sclerites: (0) absent (e.g. Fig. 22g); (1) present (Fig. 22h: pesc).

75. Lateral expansion of empodial sclerites: (0) absent (e.g. Fig. 20a-d); (1) present (Fig. 20e). Only present in Nargiotes and Nargomorphus.

76. Connection between empodial sclerites (esc) and median sclerite (ms) (Antunes-Carvalho and Gnaspini, 2016: Ch6): (0) fused (e.g. Fig. 20b, c); (1) separated by incision (Fig. 20d, e).

77. Connection between empodial sclerites (esc) and empodial setae (est) (Antunes-Carvalho and Gnaspini, 2016: Ch7): (0) articulated (Fig. 18); (1) at least partly fused (e.g. Fig. 20).

78. Arrangement of empodial setae (est) (Antunes-Carvalho and Gnaspini, 2016: Ch8): (0) side-byside (e.g. Fig. 21a, b); (1) twisted (e.g. Fig. 21c, d). Not applicable when only a single seta is present (Ch80(1)).

79. Empodial setae (est) (Antunes-Carvalho and Gnaspini, 2016: Ch9): (0) not fused at base (e.g. Fig. 21a, b); (1) fused at base (e.g. Fig. 21c, d). Not applicable when only a single seta is present (Ch80(1)).

80. Outer empodial seta (est): (modified from Antunes-Carvalho and Gnaspini, 2016: Ch10): (0) present, even if strongly reduced (e.g. Fig. 21); (1) absent (Fig. 22a, b). 
81. Outer empodial seta (est): (modified from Antunes-Carvalho and Gnaspini, 2016: Ch10): (0) normal size (including cases of asymmetry; e.g. Fig. 21); (1) minute seta (Fig. 22a-h); (2) knob-like structure (Fig. 22i, j). Not applicable if the outer empodial seta is absent $(80(1))$.

82. Inner empodial seta of foreleg: (0) subcylindrical; (1) strongly flattened. Only present in Ptomaphaminus (see Antunes-Carvalho and Gnaspini, 2016: fig. 9L: est).

83. Inner empodial seta of middle leg: (0) subcylindrical; (1) strongly flattened.

84. Inner empodial seta of hind leg: (0) subcylindrical; (1) strongly flattened. The inner empodial sera is present in the four species of Paulipalpina (see Antunes-Carvalho and Gnaspini, 2016: fig. 9I, K: est).

85. Dorsal surface of claws: (0) scale-like (Fig. 24a); (1) grooved (e.g. Fig. 24b); (2) smooth (e.g. Fig. $24 \mathrm{c}, \mathrm{d})$.

86. Row of strong teeth (tc) at basolateral margin of claw (Antunes-Carvalho and Gnaspini, 2016: Ch11): (0) absent (e.g. Fig. 23b, d); (1) present (e.g. Fig. 23a: tc).

87. Long, lateral spines close to base of claws (sbc) (Antunes-Carvalho and Gnaspini, 2016: Ch12):

(0) absent (e.g. Fig. 23a, b); (1) present (Fig. 23d: sbc).

88. Set of spines on dorsolateral surface of claws (slc) (Antunes-Carvalho and Gnaspini, 2016: Ch13):

(0) absent; (1) present (Fig. 23b: slc).

89. Set of small spines on dorsal surface of base of claws (sdc) (Antunes-Carvalho and Gnaspini, 2016: Ch14): (0) absent; (1) present (Fig. 23c: sdc).

90. Transverse groove on claws (tgc) (Antunes-Carvalho and Gnaspini, 2016: Ch15): (0) absent (e.g. Fig. 24a, b); (1) present (Fig. 24c, d: tgc).

91. Pad-like structure below claws: (0) absent; (1) present. Only present in Leptinus.

Abdomen and aedeagus

92. Longitudinal carina on first abdominal ventrite: (0) absent; (1) present. This feature occurs only in Sciaphyes (see Fresneda et al., 2011: fig. 20).

93. Apical symmetry of penis: (0) symmetric (e.g. Fresneda et al., 2011: fig. 54); (1) asymmetric (e.g. Fresneda et al., 2011: fig. 56).

94. Basal lamina of aedeagus: (0) absent (e.g. Fresneda et al., 2011: fig. 56); (1) present (e.g. Fresneda et al., 2011: fig. 54).

95. Apex of parameres (Fresneda et al., 2011: Ch 22): (0) not tapering towards acuminate apex (e.g. Fresneda et al., 2011: fig. 53); (1) tapering towards acuminate apex (e.g. Giachino and Vailati, 1987: fig. 8). Not applicable if parameres are strongly reduced (e.g. Zeanecrophilus). 
96. Parameres: (0) fused to aedeagus (e.g. Fresneda et al., 2011: figs 55, 56); (1) free, not fused to aedeagus (e.g. Fresneda et al., 2011: figs 53, 54, 57). Not applicable if parameres are strongly reduced (e.g. Zeanecrophilus).

97. Ventral lamella of tegmen (modified from Fresneda et al., 2011: Ch 25): (0) present (e.g. Fresneda et al., 2011: figs 8, 10); (1) absent (e.g. Gnaspini et al., 1996: figs 60, 61).

\section{Phylogenetic analysis}

The heuristic search with equal weights of characters yielded 1194 most parsimonious trees of 438 steps, with a consistency index (CI) of 0.25 and a retention index (RI) of 0.80 . The strict consensus tree (CI 0.21, RI 0.75) with Bremer Support values (BS) for each branch is shown in Fig. 25. Most nodes received low nodal support. Cholevinae was recovered as monophyletic and sister to Agyrtodes. Oritocatopini plus Eucatopini were recovered as sisters to the remaining Cholevinae, with Eucatops nested within Oritocatopini. Within the Cholevinae minus Eucatopini + Oritocatopini, Eunemadina was recovered as a polyphyletic assemblage of four individual branches placed in a polytomy with the rest of the taxa; Paracatopina was sister to Falkocholeva. Anemadina was recovered as sister group of Cholevini, the latter monophyletic with the exclusion of Cholevinus. Catopina and Cholevina were almost mutually monophyletic, barring the exclusion of Cholevinus from the former and of Prionochaeta from the latter. The grouping of Cholevini (Cholevinus excluded) plus Anemadina was placed in a trichotomy containing Cholevinus and a broad clade comprising the rest of Cholevinae. Within this clade, Ptomaphagini was monophyletic, as well as its constituent subtribes Ptomaphagina and Ptomaphaginina. Leptodirini was monophyletic except for the inclusion of Sciaphyes, which formed a trichotomy with Platycholeus and the Old World Leptodirini. The grouping Ptomaphagini + Schiaphyini + Leptodirini was placed in a trichotomy with Micronemadus and Nemadus, and this entire clade was recovered as sister to Eocatops. The additional analysis including Baryodirus recovered this genus within Ptomaphagini and close to Proptomaphaginus and Ptomaphaminus (i.e. inside Ptomaphaginina; see Appendix S1).

The implied weighting analysis resulted in 181 most parsimonius trees, whose strict consensus is depicted in Fig. 26. The consensus tree is mostly compatible with that under equal weighting. Major topological differences are: (1) the inclusion of Leptinus within Cholevinae and sister to the clade comprising all cholevine taxa minus Oritocatopini + Eucatopini; (2) the recovery of Eunemadina as monophyletic (with a nested inclusion of Paracatopina); and (3) the change of position of Anemadina, Prionochaeta and Cholevinus. Furthermore, Sciaphyini was reconstructed as sister to Leptodirini. Therefore, the latter tribe was found to be monophyletic, with Platycholeus as sister taxon of all Old 
World leptodirines. As in the equal weighthing analysis, most nodes were weakly supported; as a whole, nodes with high support in the previous analysis had similarly strong support under implied weighting.

The overall topology obtained with the Bayesian approach (Fig. 27) was largely in agreement with the results of the parsimony analyses. Main topological changes in relation to the equal weighting analysis include: (1) the placement of Rybinskiella and Prionochaeta in a polytomy containing Catopina (Rybinskiella excluded) and Cholevina (Cholevinus and Prionochaeta excluded); (2) the collapse of the node that in the parsimony analysis supported the sister-group relationship between Ptomaphagini and Sciaphyini + Leptodirini; and (3) the position of Sciaphyes. This genus was retrieved within Leptodirini and placed in a trichotomy containing Notidocharis and the rest of the Old World leptodirines. Most nodes received significant support.

\section{Discussion}

Since the monographic work of Jeannel (1936) - probably the first taxonomist addressing cholevine systematics with a phylogenetic scheme of argumentation - multiple hypotheses of suprageneric relationships have been postulated by different authors (e.g. Perreau, 1989; Giachino and Vailati, 1993; Giachino et al., 1998; Newton, 1998, 2016), in some cases producing contrasting classifications. The presently most accepted arrangement of the subfamily was proposed by Newton (1998), who also provided an inferred phylogeny based on morphological characters. All these efforts, however, did not follow formal cladistic methodology. In recent years, the knowledge on higher-level relationships in Cholevinae was renewed by two molecular-based phylogenies. These studies, however, were either addressing more inclusive taxa (McKenna et al., 2015), thus undersampling several leiodid lineages, or focusing on individual tribes (Fresneda et al., 2011).

With the data set presented in our study, with all presently described suprageneric taxa included, a formal phylogenetic investigation of Cholevinae is possible for the first time. Besides the monophyly of the subfamily, the higher-level interrelationships and the systematic validity of tribes and subtribes are of principal interest. Many of the relationships recovered by our analyses are consistent with the recent phylogenetic studies available (Fresneda et al., 2011; McKenna et al., 2015) and with the earlier hypotheses based on morphological examinations (e.g. Jeannel, 1936; Giachino et al., 1998; Newton, 1998), but there are some unexpected findings that are discussed herein.

\section{Monophyly of Cholevinae}

All analyses corroborated Cholevinae as a monophylum, except for the surprising inclusion of Leptinus in the topology with implied weights (Figs 25-27). The cholevine clade was weakly supported in the 
parsimony analyses, but strongly supported in the Bayesian tree. Two potential synapomorphies derived from the head capsule support the monophyly of the subfamily: the posterodorsal border of the exposed cephalic part abutting the anterior pronotal edge, and the presence of a genal fold covering the posterior part of the compound eyes. The monophyly of Cholevinae s.str. (i.e. excluding Leptinus) implies that these features have evolved independently in Leptinus; the second feature also occurs in other staphyliniform lineages (e.g. Hydraenidae: Jäch et al., 2000; Beutel et al., 2003; Hydrophiloidea: Beutel 1994; Beutel et al., 2001; Anton and Beutel, 2004), also apparently resulting from an independent gain. In several species of Leptodirini both cephalic characteristics are secondarily absent, presumably as a result of morphological changes related to subterranean habits.

The monophyly of cholevines has been challenged at least twice based on molecular data, implying the exclusion of Afrocatops in McKenna et al. (2015) and of Eucatops in Fresneda et al. (2011). However, the subfamily has been supported as a phylogenetic entity by Newton $(1998,2016)$ in an informal morphology-based character evaluation. Potential cholevine synapomorphies pointed out by Newton (1998) are the far-reaching reduction (or even loss) of the abdominal spiracle VIII and the presence of vesicles ('Hamann's Organ') on antennomeros 7, 9 and 10. However, the same features occur in other non-cholevine leiodids - the former at least in Camiarinae and Coloninae, while the latter may be found within Coloninae, Leiodinae and Platypsyllinae (see e.g. Peck, 1977; Newton, 1998; Wheeler and Miller, 2005; Park et al., 2014). The elytra lacking striae and the blunt postcoxal hypomeral projection were also assessed as probable synapomorphies by Newton (1998), but these interpretations were not confirmed by our analyses. The absence of elytral striae was not treated as a single character state here (see character 53), and the blunt postcoxal hypomeral projection was recovered as a synapomorphy of a more inclusive clade encompassing Cholevinae, Agyrtodini and Camiarini.

\section{Early diverging cholevines: Oritocatopini and Eucatopini}

All analyses converged upon a basal dicotomy between Oritocatopini + Eucatopini and the remaining Cholevinae (with inclusion of Leptinus in the implied weighting analysis; Figs 25-27). Chappuisiotes and Afrocatops form a grade with respect to Eucatops. Potential synapomorphies uniting these genera include the oblique lateral opening of the procoxal cavity, a slightly concave posterior mesepimeral margin, and a distinct acute angle formed by the posteromesal mesepimeral corner. A close relationship between Eucatopini and Ptomaphagini was initially proposed by Jeannel (1936), and both have been allied to Oritocatopini in current taxonomic treatments (e.g. Perreau, 1989; Giachino et al., 1998; Newton, 1998, 2016). Characteristics used to group eucatopines and ptomaphagines (in the erstwhile subfamily Eucatopinae; see Jeannel, 1936) include the shared presence of a tibial comb of 
spines and an incomplete tegmen with parameres inserted directly on the aedeagus. However, both features are weak evidence. The tibial comb of spines occurs in other leiodids and variations in this feature deserve further investigation (the categorization of varying arrangements of apical tibial spines is not fully elucidated yet). Moreover, the homology between the incomplete tegmen of each tribe is controversial and probably resulted from independent reductions, taking into account the different structural composition of the aedeagus in these groups (Gnaspini, 1994; Newton, 1998). Therefore, our results corroborate the close relationship between Eucatopini and Oritocatopini, and refute the traditional hypothesis of phylogenetic affinities between eucatopines and ptomaphagines (as indicated in Antunes-Carvalho and Gnaspini, 2016), placing the latter as the sister lineage of Sciaphyini + Leptodirini (see below).

Together with Sciaphyini (with only three species), Eucatopini and Oritocatopini are the least diverse tribes of Cholevinae, with 39 and 19 species, respectively (Newton, 2016). These two taxa exhibit a unique combination of plesiomorphies that distinguish them from any other cholevines, such as the retention of an elongate apical maxillary palpomere and the presence of empodial setae distinct from the empodial sclerites. A plesiomorphy added by Newton (1998) is the retained and possibly functional spiracle on abdominal segment VIII, in contrast to its absence in other cholevines. Interestingly, Eucatops and Afrocatops have been retrieved outside the phylogenetic limits of Cholevinae in the molecular studies of Fresneda et al. (2011) and McKenna et al. (2015). This result could be an artefact due to taxonomic undersampling. In fact, the present phylogenetic analysis is the first to include both Oritocatopini and Eucatopini in a data matrix. Although their phylogenetic proximity has already been argued in the literature (e.g. Giachino, 1998; Newton, 1998), the nested position of the Neotropical Eucatopini within the African Oritocatopini is unexpect and deserves further attention.

The monophyly of Eucatops, the only genus of Eucatopini, is corroborated and highly supported. Derived characteristics of this monotypic tribe are the absence of a hypostomal suture, the presence of a longitudinal ridge at the lateral margin of the mentum, the truncate anterior clypeal portion, the short medial notch at the posterior margin of the prosternal process, the very slender metanepisternum, and the absence of a ventral lamella of the tegmen. All of them also occur in other leiodids, but likely as results of parallel evolution. A unique synapomorphy is the presence of a ventrally directed plate on the prosternum, forming a precoxal coverage.

Within Cholevinae, the tribes Anemadini, Cholevini, Ptomaphagini, Sciaphyini and Leptodirini formed a broad clade in all analyses. The contiguous mesocoxal cavities, the presence of minute setae on the elytra, and the fusion of the empodial sclerites and empodial setae are some of the potential synapomorphies supporting this group, although reversals occur multiple times. The pore plate on the 
maxillary palp is an unusual character restricted to this group. Pore plates were first described by Antunes-Carvalho et al. (in press) in Catops, and have been found in all cholevine tribes except Eucatopini and Oritocatopini (not examined in Sciaphyini). Also in contrast to Eucatopini and Oritocatopini, all other cholevines share the reduced apical maxillary palpomere and the presence of an occipital ridge, even though this structure has been lost in modified leptodirines. It is still unclear, however, if both features have evolved independently in Leptinus, or if they constitute synapomorphies of Leptinus plus Cholevinae (Eucatopini and Oritocatopini excluded). In Fresneda et al. (2011), both morphological and molecular data placed Leptinus outside Cholevinae.

\section{Systematic validity of Anemadini and Cholevini}

A clade formed by Anemadini + Cholevini has been suggested based on the broadly contiguous mesocoxal cavities, a single apical tooth on the larval lacinia, and a strong larval hypopharyngeal bar, with hypopharyngeal muscle disks reduced or absent, among other traits (Newton, 1998, 2016). However, the sister group relationship of these tribes was refuted in all analyses, as well as their respective monophyly (Figs 25-27).

In this study all subtribes of Anemadini were sampled for the first time in a phylogenetic analysis. Anemadini was consistently recovered as polyphyletic. The genera of Eunemadina were subdivided into four individual lineages placed in a polytomy with an extensive clade comprising the rest of less inclusive Cholevinae, under equal weighting and Bayesian inference. One of the groupings was composed of Falkocholeva + Paracatopina. In the analysis with implied weighting, however, the constituents of both Eunemadina and Paracatopina together form a single clade. Characters supporting Eunemadina (with Paracatopina nested within) are the anterior clypeal margin delimited by a ridge and a medial incisure dividing the median empodial sclerite. A unique derived trait is the separation of the empodial and median sclerites by an incision. The medial projection of the terminal tarsomere bears an oblique row of spines in all members of this clade, with the exception of Nargiotes. However, the same peculiar set of spines does also occur in other leiodids within and outside Cholevinae. The monophyly of Eunemadina, taxon erected by Newton (1998), has never been tested. Newton (1998) emphasized that Eunemadina and Paracatopina differ distinctly from the remaining subtribes of Anemadini. This included features of the prosternum, meso- and metaventrite, and antenna, but most of them were not illustrated in his work. The affinity between Eunemadina and Paracatopina was also suggested by McKenna et al. (2015), although in this study Prionochaeta was placed between them. McKenna et al. (2015) also recovered this clade as the sister group of all remaining sampled Cholevinae (Oritocatopini excluded), a scenario that agrees with our results. 
Unlike all other Anemadini, Eunemadina and Paracatopina have an austral distribution pattern. With the exception of the Neotropical-Nearctic Dissochaetus, the species of Eunemadina are scattered throughout the Austral kingdom (senso Morrone, 2002), with most members in the Andean, Neoguinean, Australotemperate and Neozelandic regions, and some species extending into the Indonesian territory (Newton, 1998; Perreau, 2000). Paracatopina, in turn, is restricted to New Zealand and nearby islands. Our results, therefore, seems to mirror the geographic overlap of these groups.

The position of Anemadina is still uncertain. The taxon, here represented by its most diverse genera Anemadus and Speonemadus, was recovered either as sister to Cholevini (in the equal weighting and Bayesian analyses), or at the base of a clade including members of Cholevini, other Anemadini, Ptomaphagini, Sciaphyini, and Leptodirini (in the implied weighting analysis). In both cases the node support was low. A derived feature that sustains Anemadina as monophyletic is the distictly widened posterior edge of the mesocoxal cavities, also present in Leptodirini. The expansion of the mesotarsus in males of Anemadina probably represents a reversion from the apomorphic condition of having nonexpanded mesotarsomeres, found in most Cholevinae. Fresneda et al. (2011) suggested a sister group relationship of Anemadina and Sciaphyini, and both tribes were placed close to Cholevini. More data are needed to infer the phylogenetic location of Anemadina within Cholevinae.

Eocatopina and Nemadina were recovered close to the clade including ptomaphagines, leptodirines and Sciaphyes. Eocatops was consistently retrieved as sister to this grouping, albeit with low nodal support. The absence of areolae around the setal pits of the vertex, the acute medial notch at the posterior prosternal margin and the metaventral carina originating at the lateral edge of the mesocoxal cavity are characters that support this node. Nemadus and Micronemadus were placed at the base of the Ptomaphagini + Sciaphyini + Leptodirini grouping in parsimony analysis, or in a polytomy with Ptomaphagini and Leptodirini (with Sciaphyes nested in the latter) with Bayesian inference. Characteristics supporting the clade containing all these taxa include the absence of the hypostomal sutures (reverted in the Old World leptodirines), the non-pectinated meso- and metatibial spurs (reverted in Sciaphyes and Old World leptodirines), and the paired medial projection of the terminal tarsomere (reverted in Sciaphyes). The set of small spines on the dorsal surface of the claws is shared exclusively by Micronemadus and Ptomaphagini, but the optimization is ambiguous in the analysis with implied weights. A sister group relationship between Nemadina and Ptomaphagini was also recovered by McKenna et al. (2015).

Most genera of Cholevini formed a monophylum, but the position of Cholevinus, Prionochaeta and Rybinskiella were sensitive to the phylogenetic approach. Cholevinus was invariably recovered outside Cholevini. The monophyly of Cholevini excluding Cholevinus and Prionochaeta (from the implied weighting scheme) is only sustained by the absence of the longitudinal mesoventral carina. If 
Prionochaeta is included (as in the equal weighting and Bayesian analyses), the clade is then additionally supported by the absence of distinct striae and striolations on the elytra. Prionochaeta was placed outside Cholevini in McKenna et al. (2015).

Catopsimorphus, Choleva and Nargus formed a clade in all analyses, and also Apocatops, Catops, and Sciodrepoides - which would be equivalent, respectively, to Cholevina minus Prionochaeta, and Catopina minus Cholevinus and Rybinskiella. The former group is strongly supported by two unusual pretarsal characters: the transformation of the outer empodial seta into a knob-like structure and the presence of long spines at the lateral base of the claws. Such features were described in Antunes-Carvalho and Gnaspini (2016) and are unique to this clade, save for the cooccurrence of lateral spines in Sciaphyes. Catopsimorphus + Choleva + Nargus are further supported by the absence of an areola around the setal pits of the vertex. The clade composed by Apocatops, Catops, and Sciodrepoides is supported by the absence of the frontoclypeal strengthening ridge and the presence of an oblique row of spines on the medial projection of the terminal protarsomere. The inclusion of Rybinskiella in this group, as found in the parsimony analyses, is supported by the presence of very slender parameres tapering towards a fine point.

Cholevina and Catopina have been considered a homogeneous grouping since the extensive study of Jeannel (1936). Their members have been distinguished mainly by the presence of expanded mesotarsomeres among males of Catopina and its absence among Cholevina, save for some exceptions (e.g. Jeannel, 1936; Newton, 1998). Even after some criticism on this subdivision, Newton (1998) retained them as separate subtribes, but highlighted the need for further investigation. The narrow relationship between Cholevina and Catopina has also been suggested by Fresneda et al. (2011) and McKenna et al. (2015), even though based on a poor generic sampling for these subtribes. Our results show that they can be considered as separate clades after some taxonomic rearrangements.

\section{Monophyly of Ptomaphagini and internal subdivisions}

Ptomaphagini was invariably corroborated as a monophylum with high support in all analyses (Figs 25-27). Although the monophyly of the tribe has never been satisfactorily tested, ptomaphagines have been recognized by cholevine taxonomists as a natural entity, even though without a convincing synapomorphy. Two previous phylogenetic investigations have suggested the monophyly of the tribe, but both were based on insufficient ingroup (Fresneda et al., 2011) or outgroup sampling (Gnaspini, 1996).

Potential synapomorphies we detected include the distinctly narrowed apical maxillary palpomere, the oblique lateral opening of the procoxal cavity, the approximately horizontal orientation of the mesothoracic pleural suture, the apical asymmetry of the penis, and the absence of a ventral 
lamella of the tegmen. A unique synapomorphy is the $\mathrm{V}$-shaped depression at the distal extension of the unguitractor plate (Antunes-Carvalho and Gnaspini, 2016). The glabrous apical maxillary palpomere, the absence of the basal lamina of the aedeagus, and the fusion of the parameres to the aedeagus are plesiomorphic traits shared by members of this tribe. The set of small spines on the dorsal surface of the base of the claws is an apomorphy almost exclusively found in Ptomaphagini, save for its occurrence in Micronemadus. Ptomaphagini is further characterized by having the truncated anterior clypeal portion, a derived condition that is only observed in Eucatops, Paracatops and Sciaphyes among Cholevinae.

Although the mutual monophyly of the constituent subtribes Ptomaphagina and Ptomaphaginina was retrieved (but see remark about Baryodirus, next), their support is weak and based on characters with questionable independence. An additional support for Ptomaphagina is the characteristic longitudinal ridge on the lateral margins of the mentum, a feature described here for the first time. The division of Ptomaphagini into subtribes was refuted by Gnaspini (1996), although this has not been adopted in subsequent studies, which still recognise Ptomaphagina and Ptomaphaginina (e.g. Newton, 1998; Perreau, 2000, 2004; Bouchard et al., 2011).

Perreau (2000) described Baryodirina, a monotypic subtribe of Ptomaphagini based on a single female of Baryodirus collected in Gunung Mulu, Malaysia. Morphological peculiarities of the subtribe include the tetramerous protarsi, a dual setation on pronotal and elytral surface, and a strongly developed median longitudinal carina (Perreau, 2000). However, the placement of Baryodirus in Ptomaphagini has never been tested cladistically. With this intention, we conducted an additional parsimony analysis including Baryodirina in the data matrix. Both equal and implied weighting analyses corroborated the inclusion of Baryodirina in Ptomaphagini (Appendix S1), even though most synapomorphies of the tribe could not be confirmed for Baryodirus owing to lack of information. Although a longitudinal ridge is present at the lateral margin of the mentum - a characteristic recovered as synapomorphic for Ptomaphagina - the genus was nested inside the Ptomaphaginina clade due to the row of teeth at the lateral base of the claws, even though the presence of such spines on the middle and hind legs is not as clear as in the case of the foreleg (see Perreau, 2000: figs 8-10). Indeed, morphological similarities of Baryodirina and Ptomaphaginina have been noted by Perreau (2000), such as the comb of spines along the external edge of protibial and around its apex. In our analyses, Baryodirus was recovered close to Proptomaphaginus and Ptomaphaminus, suggested by the mesoventral process extending beyond the posterior edge of the mesocoxal cavities but not reaching the midlength of metaventrite.

The sister group relationship between Ptomaphagini and Sciaphyini + Leptodirini was recovered in the parsimony analyses, whereas both clades were retrieved in a polytomy with Nemadus 
and Micronemadus in the Bayesian analysis, though with low nodal support in all cases. Derived features uniting Ptomaphagini with Leptodirini + Sciaphyini are the slightly concave posterior mesepimeral margin, the acute angle formed by the posteromesal mesepimeral corner, and the incomplete suture between the mesanepisternum and mesoventrite, the latter representing an unambiguous change. The separation of the mesocoxal cavities and absence of minute setae on the elytra are plesiomorphic traits shared by these tribes. A phylogenetic proximity involving Nemadina, Ptomaphagini and Leptodirini was suggested by McKenna et al. (2015), whereas they are not shown as related taxa in the phylogeny of Fresneda et al. (2011).

\section{Controversials around the phylogenetic placement of Sciaphyes}

Sciaphyes, the single genus of Sciaphyini, is a poorly known taxon with only three species of small body size and restricted to the Russian Far East (S. sibiricus and S. shestakovi) and Tsushima Island (S. kawaharai) of Japan (Fresneda et al., 2011). The genus has been ascribed to Leptodirini for more than a century. The first species was described as a leptodirine (under the name Bathyscia sibirica Reitter) until Perreau (2000) allocated it into an individual tribe. The five-segmented protarsi of females, the presence of two empodial setae, and the characteristics of the pterothorax and abdominal venter were used by Perreau (2000) as main arguments to exclude Sciaphyes from Leptodirini (thought most leptodirines also possess two empodial setae; see Antunes-Carvalho and Gnaspini, 2016).

Different hypotheses on the phylogenetic placement of Sciaphyes within Cholevinae were presented. A sister group relationship between Sciaphyini and Leptodirini was proposed by Newton (2005) based on characters such as a fourth palpomere shorter than the third, the non-confluent metacoxae, and the short, ring-like male genital segment in both tribes. However, none of these features constitute strong evidence of relationship and the author himself noted the tenuous support of this clade. Shortening of the apical palpomere occurs in most lineages of Cholevinae, except in the basal Eucatopini and Oritocatopini, and separated mesocoxae are plesiomorphic in the subfamily. Moreover, the reduction of the male genital segment of Sciaphyes is not as pronounced as in Leptodirini. In fact, the typical ring-like shape of the genital segment occurs exclusively in leptodirines (see Fresneda et al., 2011). Hoshina and Perreau (2008) emphasized the 'intermediate' nature of the characters of Sciaphyes between Ptomaphagini and Leptodirini, such as the carinae associated to the posterolateral edge of mesocoxal cavities (here subdivided into two individual characters: 46 and 48), and the different degrees of reduction of the male abdominal segment IX. According to Hoshina and Perreau (2008), the absence of eyes and the body depigmentation in both groups are results of convergent evolution associated to a subterranean lifestyle. 
In contrast to earlier hypotheses, a sister group relationship between Sciaphyini and Anemadini was recently suggested by Fresneda et al. (2011) based on molecular evidence, although with weak nodal support. Morphologically, the proximity between the tribes was mainly justified by similarities of the male copulatory apparatus. For instance, Sciaphyes share with Anemadina a weakly curved median lobe and a strongly delevoped basal lamina with recurved lateral margins almost forming a tube (Fresneda et al., 2011). Parameres longer than the penis and of similar width along their entire length are common to both groups. Similarities in the structure of the aedeagal internal sac were also noticed by Fresneda et al. (2011), considering the internal sac of Sciaphyes with two longitudinal bands more similar to Eunemadina and Nemadina than to that of Anemadina.

Our study emphasizes the uniqueness of the Sciaphyini lineage, but does not resolve its phylogenetic affinities. This uncertainty is at least in part due the unusual character combination of Sciaphyes, with features irregularly distributed among other cholevine lineages. The shallow, transverse ridge close to the anterior margin of the mentum is a derived feature shared with Eucatopini and Oritocatopini (and some outgroup taxa). In these tribes and in Sciaphyes, the suture separating the mesanepisternum and mesepimeron is not visible externally, a condition also occurring in the clade of Eunemadina and Paracatopina, and also in a few leptodirines. In turn, the long, lateral spine associated to the base of the claws is a remarkable character shared exclusively with Cholevina (excluding Prionochaeta). With leptodirines, Sciaphyes share the smooth dorsum of the claws. Finally, the longitudinal carina on the metavetrite is shared with Catopocerus (a non-cholevine leiodid), while the carina on the first abdominal ventrite is an autapomorphy of Sciaphyini.

Despite of this mixture of phenotypic traits, our analyses retrieved Sciaphyes always related to Leptodirini, either in a trichotomy with Platycholeus and all remaining leptodirines (equal weighting, Fig. 25), or as sister to a monophyletic Leptodirini (implied weighting, Fig. 26), or nested within Leptodirini (Bayesian analysis, Fig. 27). Several characteristics support the grouping of these two tribes, but are either homoplastic apomorphies, such as the distictly widened posterior edge of the mesocoxal cavity and the narrow metanepisternum, or reversals, which include the frontoclypeal strengthening ridge, the absence of an elevated occipital ridge, the bifid metaventral process, and the absence of parasutural elytral stria. Additional similarities not recorded before are the pectinate ventral tibial spurs of the middle and hind legs and the transverse groove on the claws. Both characters are present in all leptodirines except Platycholeus and Hadesia. The latter feature is not found in any other leiodid group. It appears that a combination of extensive morphological and molecular data will be required to assess the phylogenetic affinities of Sciaphyini reliably. Without confirming or refuting alternative hypotheses of relationships, we show that the phylogenetic placement of this enigmatic lineage is problematic and still open. 


\section{Basal dichotomies and novel morphological elements in Leptodirini}

Leptodirini is one of the most impressive subterranean radiations of beetles. The tribe, the most species-rich and intensively studied of Cholevinae, encompasses seven subtribes and ca. 930 species mostly distributed in the Palaearctic region (with a single Nearctic genus; Newton, 2016). The restricted distribution of most leptodirine genera and species offers an exciting data collection for biogeographical investigations. The phylogenetic knowledge of Leptodirini has distinctly improved in recent years (Fresneda et al., 2007; Ribera et al., 2010; Fresneda et al., 2011; Cieslak et al., 2014), even though covering only a fraction of its extraordinary diversity. The monophyletic origin has been demonstrated on the basis of morphological (Fresneda et al., 2007) and molecular evidence (Ribera et al., 2010; Fresneda et al., 2011). Although not covering the great diversity of genera in the tribe, the present contribution is the first to sample representatives from all subtribes and to offer comprehensive information on the external morphology (morphology-based phylogenies are mostly focused on genitalic structures, e.g. Fresneda et al., 2007, 2011). Our data confirm some previous findings, but the poor topological resolution does not allow an in-depth discussion of the internal relationships. Nevertheless, two interesting morphological features of Leptodirini are addressed for the first time: the projecting sensilla on the apical maxillary palpomere and the pore plates on the terminal tarsomere.

The monophyly of Leptodirini was corroborated, save for the inclusion of Sciaphyes in the trees produced by equal weighting analysis and Bayesian inference. Leptodirini s. str. is supported by a reduction in the number of protarsomeres in females (from five to four), also considered an autapomorphy of the tribe in previous investigations (e.g. Fresneda et al., 2007, 2011) and used to charaterize the group by earlier authors (e.g. Jeannel, 1936; Giachino et al., 1998; Newton, 1998). Another characteristic supporting the group is the presence of a set of projecting sensilla on the apical maxillary palpomere; in non-leptodirines the same palpomere bears digitiform sensilla adpressed to the surface. The projecting sensilla are an almost unique synapomorphy of Leptodirini, barring its occurence in Nargomorphus (Anemadini), and a possible reversal in Spelaeobates. This feature has been observed by Moldovan et al. (2004) in Closania and Tismanella, and by Njunjić et al. (2016) in Anthroherpon, Leptomeson and Graciliella, but without any phylogenetic interpretation. Here we report the broad occurrence throughout Leptodirini and show the phylogenetic relevance of this derived character for the first time. Although the sensilla have not been found in Hadesia by Njunjić et al. (2016), we confirm its presence in Hadesia vasiceki.

The basal dichotomy between Platycholeus and the Old World leptodirines is in agreement with Fresneda et al. (2011), and also with earlier hypotheses (Jeannel, 1924; Newton, 1998). This genus - the only one of Platycholeina - has three species and is the single taxon of Leptodirini with 
well-developed compound eyes and hind wings, in contrast to all remaining flightless species without or with reduced eyes. Platycholeus is also unique by its distribution, as the single leptodirine branch in the New World. A possible autapomorphy suggested by our analyses is the loss of the outer empodial seta, but the taxon is also supported by reversals which include the smooth anterior clypeal margin, the missing medial notch at the posterior prosternal margin, and the complete suture between mesanepisternum and mesoventrite. Other plesiomorphies are the simple meso- and metatibial ventral spurs, in contrast to the pectinate spurs of other leptodirines, and the absence of the characteristic transverse groove on the claws. The Old World Leptodirini is sustained by the presence of the hypostomal suture, a mesoventral process extending beyond the posterior edge of the mesocoxal cavities but not reaching the midlength of the metaventrite, and the microsculptured dorsal elytral surface (reversals and other states of these characters occur in different branches within the group). The basal fusion of empodial setae is a derived character exclusive to this clade, but it is unclear if this has evolved in the common ancestor of the Old World Leptodirini, or whether it is a ground plan apomorphy of the tribe with subsequent loss of the outer empodial seta in Platycholeus.

Amongst the Old World Leptodirini, Notidocharis appears as sister to the large and unresolved clade composed by all remaining leptodirines, though with weak support. The basal position of Notidocharis was also suggested in other studies (e.g. Fresneda et al., 2007; Cieslak et al., 2014). The minute outer empodial seta is a derived trait of this genus, but with independent origins within Leptodirini. Except for Spelaeobatina (with a single genus) and Anthroherponina (with two genera sampled), all other subtribes were non-monophyletic. This broad grouping of leptodirines includes several higly modified species, and the unresolved topology probably reflects numerous convergent features related to underground life. The modern subtribal classification is obsolete and requires a profound revision, a herculean task in face of the immense diversity of the taxon. The smooth dorsum of the claws and the twisting of the empodial setae are synapomorphies of the the Old World leptodirines (Notidocharis excluded), the latter feature representing an unambiguous change. Although a drastic reduction of the outer empodial seta has occurred in some species of Pholeuina, the twisted nature of the setae can be recognized.

Our character survey uncovered a novel structure in Leptodirini: a set of pore plates on the cuticular surface of the terminal tarsomere, probably associated with glands. This structure was identified in members of five of the seven subtribes. Pore plates were not observed in Platycholeina and Spelaeobatina, as well as in any other leiodid studied here. Under implied weighting, the presence of this feature yielded a potential synapomorphy of a large clade within Leptodirini. In the analysis with equal weights, the occurrence of this structure constituted an unambiguous change sustaining all Old World leptodirines with the exception of Notidocharis. They are generally distributed on the lateral 
and dorsal surfaces of the terminal tarsomere of all legs, mostly associated to the base of the tarsal setae. Betz (2003) reported similar structural modifications on the tarsi of Stenus (Staphylinidae). He demonstrated their association to a unicellular gland of uncertain function, but possibly related to the tarsal adhesive performance. The function of the maxillary sensilla and tarsal pore plates in leptodirines are unknown. Both structures open new avenues of investigation in functional morphology, ultrastructure and behaviour of Leptodirini.

\section{Conclusion}

The cladistic hypothesis for Cholevinae presented here is the most comprehensive one presently available. For the first time an extensive set of morphological characters was scored for a broad taxon sampling and analysed with different approaches. Members from all suprageneric taxa were sampled largely covering the global distribution of the subfamily, including the south temperate regions, which were found to harbour the basal lineages of the Cholevinae.

The monophyly of Cholevinae was confirmed, except for the unexpected inclusion of Leptinus in the implied weighting analysis. Contrary to other works, Eucatopini and Oritocatopini were retrieved as basal branches. The monophyletic origin of all remaining tribes was corroborated, which is congruent with molecular evidence. Anemadini turned out as non-monophyletic, confirming earlier hypotheses. Cholevini was rendered non-monophyletic by the uncertain inclusion of Prionochaeta and the consistent exclusion of Cholevinus. The affinity of Ptomaphagini with Sciaphyini and Leptodirini was suggested, even though the position of Sciaphyes is still not precisely defined. Nemadina was invariably associated to these tribes, and Eocatopina was consistently recovered as the sister taxa of this clade involving the three tribes plus Nemadina.

Although genitalic structures have historically played a pivotal role in inferences of relationships among genera, homology hypotheses of various components of the male copulatory apparatus become problematic with increasing phylogenetic distance, namely at the tribal level. Our study provided several characters from other body parts and a morphological documentation based on SEM micrographs. Most of the characters have never been used in a phylogenetic context in Cholevinae. Many of them were only described and documented in recent years, such as those from the pretarsus and distal margin of the terminal tarsomere, and were tested for the first time in this study. The list of characters shows that substantial parts of the data were obtained from the ventral side. This is a strong argument for a detailed pictorial documentation of the ventral view in taxonomic descriptions, in contrast to the common practice of only illustrating the dorsal habitus of these beetles. In addition to the recent finding of maxillary pore plates in Cholevinae, the discovery of the broad 
occurrence of tarsal pore plates and projecting sensilla in the maxillary palp of Leptodirini show that even the most well-known cholevines continue to offer valuable rewards for careful morphological investigations. In face of the increasing volume of available molecular data involving Cholevinae, the present contribution represents an additional step towards the total evidence analysis of the group.

\section{Acknowledgments}

We thank the following researchers for the generous loan or donation of the studied material: Alfred F. Newton and Crystal Maier (Field Museum of Natural History, Chicago, USA), Andrea Colla (Museo Cívico di Scienze Naturali, Trieste, Italy), Cristiano Lopes Andrade (Universidade Federal de Viçosa, Viçosa, Brazil), Stefano Zoia and Fabrizio Rigato (Museo di Storia Naturale di Milano, Milano, Italy), Jan Růžička (Czech University of Life Sciences, Praha, Czech Republic), Jiří Hájek (Národní muzeum Praha, Praha, Czech Republic), Johannes Frisch (Museum für Naturkunde Berlin, Berlin, Germany), Michel Perreau (Université Paris 7, Paris, France), Pier Mauro Giachino (Settore Fitosanitario Regionale, Torino, Italy), Richard Leschen (Landcare Research, Auckland, New Zealand), Sônia Casari (Museu de Zoologia da Universidade de São Paulo, São Paulo, Brazil), Stewart Peck (Carleton University, Ottawa, Canada), and Thierry Deuve (Muséum National d'Histoire Naturelle, Paris, France). We thank Vasily Grebennikov for providing additional SEM images of Sciaphyes. CAC deeply thanks Hans Pohl and Margarita Yavorskaya (Friedrich-Schiller-Universität Jena, Germany), who kindly provided training and advice on scanning electron microscopy. Hans Pohl made available a rotatable specimen holder and it is also greatly appreciated. Additional SEM micrographs were obtained in the Electronic Microscopic Laboratory of IBUSP with the support of Alberto Ribeiro and Márcio Cruz. The PhD study of CAC and his research internship at the FriedrichSchiller-Universität Jena was funded by Fundação de Amparo à Pesquisa do Estado de São Paulo (FAPESP) (2012/19002-0 and 2014/22088-0). The work of IR was supported by a Salvador de Madariaga grant in the Phyletisches Museum in Jena (PRX14/00583). PG was also supported by FAPESP (2013/06314-7).

\section{References}

Antunes-Carvalho, C., Gnaspini, P., 2016. Pretarsus and distal margin of the terminal tarsomere as an unexplored character system for higher-level classification in Cholevinae (Coleoptera, Leiodidae). Syst. Entomol. 41, 392-415.

Antunes-Carvalho, C., Yavorskaya, M., Gnaspini, P., Ribera, I., Hammel, J.U., Beutel, R.G., in press. Cephalic anatomy and three-dimensional reconstruction of the head of Catops ventricosus 
(Weise, 1877) (Coleoptera: Leiodidae: Cholevinae). Org. Divers. Evol.

Anton, E., Beutel, R.G., 2004. On the head morphology and systematic position of Helophorus (Coleoptera: Hydrophiloidea: Helophoridae). Zool. Anz. 242, 313-346.

Betz, O., 2003. Structure of the tarsi in some Stenus species (Coleoptera, Staphylinidae): external morphology, ultrastructure, and tarsal secretion. J. Morphol. 255, 24-43.

Beutel, R.G., 1994. Phylogenetic analysis of Hydrophiloidea (Coleoptera: Polyphaga: Staphyliniformia) based on characters of the head of adults and larvae. Koleopterol. Rundsch. 64, 103-131.

Beutel, R.G., Anton, E., Bernhard, D., 2001. Head structures of adults of Spercheus (Coleoptera: Spercheidae): their function and possible significance to staphyliniform phylogeny. Ann. Zool. $51,473-484$.

Beutel, R.G., Anton, E., Jäch, M.A., 2003. On the evolution of the adult head structures and the phylogeny of Hydraenidae (Coleoptera, Staphyliniformia). J. Zool. Syst. Evol. Res. 41, 256275.

Beutel, R.G., Leschen, R.A.B., 2005. Phylogenetic analysis of Staphyliniformia (Coleoptera) based on characters of larvae and adults. Syst. Entomol. 30, 510-548.

Beutel, R.G., Molenda, R., 1997. Comparative morphological study of larvae of Staphylinoidea (Coleoptera, Polyphaga) with phylogenetic implications. Zool. Anz. 236, 37-67.

Bouchard, P., Bousquet, Y., Davies, A.E., Alonso-Zarazaga, M.A., Lawrence, J.F., Lyal, C.H.C., Newton, A.F., Reid, C.A.M., Schmitt, M., Ślipiński, S.A., Smith, A.B.T., 2011. Family-group names in Coleoptera (Insecta). Zookeys 88, 1-972.

Bremer, K., 1994. Branch support and tree stability. Cladistics 10, 295-304.

Caterino, M.S., Hunt, T., Vogler, A.P., 2005. On the constitution and phylogeny of Staphyliniformia (Insecta: Coleoptera). Mol. Phylogenet. Evol. 34, 655-672.

Cieslak, A., Fresneda, J., Ribera, I., 2014. Life-history specialization was not an evolutionary deadend in Pyrenean cave beetles. Proc. R. Soc. Lond. B Biol. Sci. 281, 20132978.

Fresneda, J., Grebennikov, V.V., Ribera, I., 2011. The phylogenetic and geographic limits of Leptodirini (Insecta: Coleoptera: Leiodidae: Cholevinae), with a description of Sciaphyes shestakovi sp. n. from the Russian Far East. Arthropod Syst. Phylog. 69, 99-123.

Fresneda, J., Salgado, J.M., Ribera, I., 2007. Phylogeny of Western Mediterranean Leptodirini, with an emphasis on genital characters (Coleoptera: Leiodidae: Cholevinae). Syst. Entomol. 32, $332-358$.

Giachino, P.M., Vailati, D., 1993. Revisione degli Anemadinae. Monogr. Nat. Bresciana 18, 7-314. 
Giachino, P.M., Vailati, D., 1987. Un nuovo Apocatops della fauna italiana (Coleoptera Catopidae). Boll. Mus. Reg. Sci. Nat. Torino 5, 147-156.

Giachino, P.M., Vailati, D., Casale, A., 1998. Major questions in the phylogeny and biogeography of Cholevidae (Coleoptera), with emphasis on the subfamily Leptodirinae. Atti Mus. Reg. Sci. Nat. Torino 8, 179-210.

Gnaspini, P., 1994. The genus Eucatops (Coleoptera, Cholevidae, Eucatopinae) - description of new species and considerations on its systematic position. Iheringia, Sér. Zool. 76, 33-42.

Gnaspini, P., 1996. Phylogenetic analysis of the tribe Ptomaphagini, with description of new Neotropical genera and species (Coleoptera, Leiodidae, Cholevinae, Ptomaphagini). Pap. Avulsos Zool. 39, 509-556.

Goloboff, P.A., 1993. Estimating character weights during tree search. Cladistics 9, 83-91.

Goloboff, P.A., 1999. Analyzing large data sets in reasonable times: solutions for composite optima. Cladistics 15, 415-428.

Goloboff, P.A., Carpenter, J.M., Arias, J.S., Esquivel, D.R.M., 2008a. Weighting against homoplasy improves phylogenetic analysis of morphological data sets. Cladistics 24, 758-773.

Goloboff, P.A., Farris, J.S., Källersjö, M., Oxelman, B., Ramírez, M., Szumik, C.A., 2003. Improvements to resampling measures of group support. Cladistics 19, 324-332.

Goloboff, P.A., Farris, J.S., Nixon, K.C., 2008b. TNT, a free program for phylogenetic analysis. Cladistics 24, 774-786.

Guéorguiev, B.V., Bekchiev, R., 2009. A Contribution to the Coleopteran Fauna of Bulgaria (Insecta: Coleoptera). Acta Zool. Bulg. 61, 39-44.

Jäch, M.A., Beutel, R.G., Díaz, J.A., Kodada, J., 2000. Subgeneric classification, description of head structures, and world check list of Hydraena Kugelann (Insecta: Coleoptera: Hydraenidae). Ann. Naturhist. Mus. Wien 102B, 177-258.

Jeannel, R., 1911. Révision des Bathysciinae (Coléoptères, Silphides). Morphologie, distribution géographique, Systématique. Arch. Zool. Exp. Gen. 47, 1-641.

Jeannel, R., 1924. Monographie des Bathysciinae. Arch. Zool. Exp. Gen. 63, 1- 436.

Jeannel, R., 1936. Monographie des Catopidae. Mém. Mus. Nat. d'Hist. Nat. (n.s.) 1, 1-433.

Lawrence, J.F., Beutel, R.G., Leschen, R.A.B., Ślipiński, A., 2010. Glossary of morphological terms. In: Leschen, R.A.B., Beutel, R.G., Lawrence, J.F., (Eds.), Handbook of Zoology, Vol. IV, Arthropoda: Insecta; Coleoptera, Morphology and Systematics (Polyphaga partim), Vol. 1, $2^{\text {nd }}$ ed. Walter De Gruyter, Berlin and New York pp. 9-20. 
Lawrence, J.F., Ślipiński, A., Seago, A.E., Thayer, M.K., Newton, A.F., Marvaldi, A.E., 2011. Phylogeny of the Coleoptera based on morphological characters of adults and larvae. Ann. Zool. 61, 1-217.

Lewis, P.O., 2001. A likelihood approach to estimating phylogeny from discrete morphological character data. Syst. Biol. 50, 913-925.

Maddison, W.P., Maddison, D.R. 2016. Mesquite: a modular system for evolutionary analysis. Version 3.10, available at: http://mesquiteproject.org.

McKenna, D.D., Farrell, B.D., Caterino, M.S., Farnum, C.W., Hawks, D.C., Maddison, D.R., Seago, A.E., Short, A.E.Z., Newton, A.F., Thayer, M.K., 2015 Phylogeny and evolution of Staphyliniformia and Scarabaeiformia: forest litter as a stepping stone for diversification of nonphytophagous beetles. Syst. Entomol. 40, 35-60.

Moldova, O.T., Jalžić, B., Erichsen, E., 2004. Adaptation of the mouthparts in some subterranean Cholevinae (Coleoptera, Leiodidae). Nat. Croat. 13, 1-18.

Morrone, J.J., 2002. Biogeographical regions under track and cladistic scrutiny. J. Biogeogr. 29, 149152.

Newton, A.F., 1997. Review of Agyrtidae (Coleoptera), with a new genus and species from New Zealand. Ann. Zool. 47. 111-156.

Newton, A.F., 1998. Phylogenetic problems, current classification and generic catalog of World Leiodidae (including Cholevidae). Atti Mus. Reg. Sci. Nat. Torino 8, 41-177.

Newton, A.F., 2005. Leiodidae Fleming, 1821. In: Beutel, R.G. and Leschen, R.A.B., (Eds.), Handbook of Zoology, Vol. IV, Arthropoda: Insecta; Coleoptera, Morphology and Systematics (Archostemata, Adephaga, Myxophaga, Polyphaga partim), Vol. 1, Walter De Gruyter, Berlin and New York, pp. 269-280.

Newton, A.F., 2016. Leiodidae Fleming, 1821. In: Beutel, R.G. and Leschen, R.A.B., (Eds.), Handbook of Zoology, Vol. IV, Arthropoda: Insecta; Coleoptera, Morphology and Systematics (Archostemata, Adephaga, Myxophaga, Polyphaga partim), Vol. 1, $2^{\text {nd }}$ ed. Walter De Gruyter, Berlin and New York, pp. 364-376.

Njunjić, I., Perreau, M., Hendriks, K., Schilthuizen, M., Deharveng, L., 2016. The cave beetle genus Anthroherpon is polyphyletic; molecular phylogenetics and description of Graciliella n. gen. (Leiodidae, Leptodirini). Contr. Zool. 85, 337-359.

Nixon, K.C., 1999. The parsimony Ratchet, a new method for rapid parsimony analysis. Cladistics 15 , 407-414.

Nixon, K.C., 2002. WinClada ver. 1.00.08. Published by the author, Ithaca, NY. 
Park, S.-J., Leschen, R.A.B., Ahn, K.-J., 2014. Phylogeny of the Agathidiini Westwood (Coleoptera: Leiodidae) and implications for classification and contractile morphology. Syst. Entomol. 39, $36-48$.

Peck, S.B., 1977. An unusual sense receptor in internal antennal vesicles of Ptomaphagus (Coleoptera: Leiodidae). Can. Entomol. 109: 81-86.

Peck, S.B., 1982. A review of the ectoparasitic Leptinus beetles of North America (Coleoptera: Leptinidae). Can. J. Zool. 60, 1517-1527.

Peck, S.B., 2003. The eyeless inquiline genera Parabystus and Scotocryptus of Costa Rica and Panama; inhabitants of nests of stingless bees (Coleoptera: Leiodidae). Sociobiology 42: 6580.

Peck, S.B., Cook, J., 2002. Systematics, distributions, and bionomics of the small carrion beetles (Coleoptera: Leiodidae: Cholevinae: Cholevini) of North America. Can. Entomol. 134, 723787.

Peck, S.B., Cook, J., 2007. Systematics, distributions, and bionomics of the Neoeocatops gen. nov. and Nemadus of North America (Coleoptera: Leiodidae: Cholevinae: Anemadini). Can. Entomol. 139, 87-117.

Peck, S.B., Skelley, P.E., 2001. Small carrion beetles (Coleoptera: Leiodidae: Cholevinae) from burrows of Geomys and Thomomys pocket gophers (Rodentia: Geomyidae) in the United States. Insecta Mundi 15, 139-149.

Perreau, M., 1989. De la phylogénie des Cholevidae et des familles apparentées (Coleoptera, Cholevidae). Arch Sci (Geneva) 39, 579-590.

Perreau, M., 2000. Catalogue des Coléoptères Leiodidae Cholevinae et Platypsyllinae. Mém. Soc. Entomol. Fr. 4, 1-460.

Perreau, M., 2004. Leiodidae. In: Löbl, I. and Smetana, A. (Eds.), Catalogue of Palaearctic Coleoptera Vol 2. Apollo Books, Stenstrup, pp.133-203.

Pohl, H., 2010. A scanning electron microscopy specimen holder for viewing different angles of a single specimen. Microsc. Res. Tech. 73, 1073-1076.

Rambaut, A., Drummond, A.J., 2007. Tracer v1.4. Available from http://beast.bio.ed.ac.uk/Tracer

Ribera, I., Fresneda, J., Bucur, R., Izquierdo, A., Vogler, A.P., Salgado, J.M., Cieslak, A., 2010. Ancient origin of a Western Mediterranean radiation of subterranean beetles. BMC Evol. Biol. $10,1-14$.

Ronquist, F., Huelsenbeck, J.P., 2003. MRBAYES 3: Bayesian phylogenetic inference under mixed models. Bioinformatics 19, 1572-1574. 
CAPÍTULO 3

Wheeler, Q.D., Miller, K.B., 2005. Revision of the slime-mold beetles of the genus Agathidium Panzer of North and Central America, Part I. (Coleoptera: Leiodidae). Bull. Am. Mus. Nat. Hist. 290, $1-95$. 
Table 1. List of species examined in this study.

\begin{tabular}{|c|c|c|c|c|}
\hline \multicolumn{3}{|c|}{ Systematic assignment } & \multirow[t]{2}{*}{ Species } & \multirow[t]{2}{*}{ Provenance } \\
\hline LEIODIDAE & & & & \\
\hline Cholevinae & Anemadini & Anemadina & Anemadus acicularis (Kraatz) & Monte Vulture, Potenza, Basilicata, Italy \\
\hline Cholevinae & Anemadini & Anemadina & Speonemadus bolivari (Jeannel) & Complejo del Romeral, Antequera, Málaga, Spain \\
\hline Cholevinae & Anemadini & Eocatopina & Eocatops ophidianus Szymczakowski & Akdamar Island, Van Gölü, Turkey \\
\hline Cholevinae & Anemadini & Eunemadina & Dissochaetus arizonensis Hatch & Lincoln County, New Mexico, USA \\
\hline Cholevinae & Anemadini & Eunemadina & Dissochaetus vanini Gnaspini & Iporanga, São Paulo, Brazil \\
\hline Cholevinae & Anemadini & Eunemadina & Falkocholeva sp. & Bahía de San Sebastián, Tierra del Fuego, Argentina \\
\hline Cholevinae & Anemadini & Eunemadina & Nargiotes leptocerus Szymczakowski & Bunya Mountains National Park, Queensland, Australia \\
\hline Cholevinae & Anemadini & Eunemadina & Nargomorphus amplicollis Szymczakowski & Pemberton, Western Australia, Australia \\
\hline Cholevinae & Anemadini & Eunemadina & Pseudonemaus cheesmani (Jeannel) & Mount Kaindi, Morobe, Papua New Guinea \\
\hline Cholevinae & Anemadini & Nemadina & Nemadus sp. & Nymburk, Central Bohemia, Czech Republic \\
\hline Cholevinae & Anemadini & Nemadina & Micronemadus pussilimus (Kraatz) & Japan \\
\hline Cholevinae & Anemadini & Paracatopina & Paracatops alacris (Broun) & Kerr Taylor SR, Auckland, Auckland, New Zealand \\
\hline Cholevinae & Anemadini & Paracatopina & Paracatops antipoda (Kirsch) & Adams Island, Auckland Islands, New Zealand \\
\hline Cholevinae & Cholevini & Catopina & Apocatops monguzzii Giachino \& Vailati & Rezzoaglio, Genova, Liguria, Italy \\
\hline Cholevinae & Cholevini & Catopina & Catops fuliginosus Erichson & $\begin{array}{l}\text { (a) Tossicia, Abruzzo; (b) Matajur, Friuli Venezia Giulia: } \\
\text { Italy }\end{array}$ \\
\hline Cholevinae & Cholevini & Catopina & Catops subfuscus Kellner & Monte Canin, Sella Nevea, Friuli Venezia Giulia, Italy \\
\hline Cholevinae & Cholevini & Catopina & Cholevinus fuscipes (Ménétries) & Arzni, Kotayk, Armenia \\
\hline Cholevinae & Cholevini & Catopina & Rybinskiella magnifica (Rybiński) & Chornohora, Rakhiv, Zakarpattia Oblast, Ukraine \\
\hline Cholevinae & Cholevini & Catopina & Sciodrepoides watsoni (Spence) & (a) Monti della Laga, Abruzzo; (b) Reggello, Tuscany: Italy \\
\hline Cholevinae & Cholevini & Cholevina & Catopsimorphus orientalis Aubé & Kastraki, Nemea, Corinthia, Peloponnese, Greece \\
\hline Cholevinae & Cholevini & Cholevina & Choleva agilis (Illiger) & San Tomio, Malo, Vicenza, Veneto, Italy \\
\hline Cholevinae & Cholevini & Cholevina & Choleva oblonga Latreille & Cremona, Lombardy, Italy \\
\hline Cholevinae & Cholevini & Cholevina & Nargus badius (Sturm) & Borghetto di Vara, Liguria, Italy \\
\hline Cholevinae & Cholevini & Cholevina & Prionochaeta harmandi harmandi Portevin & Omogo Valley, Mount Ishizuchi, Shikoku, Japan \\
\hline Cholevinae & Cholevini & Cholevina & Prionochaeta opaca (Say) & Natchez Trace, Henderson County, Tennessee, USA \\
\hline Cholevinae & Eucatopini & & Eucatops sp. 1 & Saint Laurent du Maroni, French Guiana \\
\hline Cholevinae & Eucatopini & & Eucatops sp.2 & Puerto Maldonado, Madre de Dios, Peru \\
\hline Cholevinae & Leptodirini & Anthroherponina & Antroherpon hoermanni (Apfelbeck) & Bjelašnica, Sarajevo Canton, Bosnia and Herzegovina \\
\hline Cholevinae & Leptodirini & Anthroherponina & Antroherpon primitivum primitivum (Absolon) & Kali pećina, Grebci, Ravno, Bosnia and Herzegovina \\
\hline Cholevinae & Leptodirini & Anthroherponina & Hadesia vasiceki Müller & Vjetrenica, Ravno, Bosnia and Herzegovina \\
\hline Cholevinae & Leptodirini & Bathysciina & Aphaobius milleri springeri Müller & Italy \\
\hline Cholevinae & Leptodirini & Bathysciina & Aphaotus jureceki Breit & Grotta di Costalta, Trento, Trentino-Alto Adige, Italy \\
\hline Cholevinae & Leptodirini & Bathysciina & Bathyscia montana Schiødte & Zalog, Upper Carniola, Slovenia \\
\hline Cholevinae & Leptodirini & Bathysciina & Oryotus schmidti Miller & Postojna Cave, Postojna, Littoral, Slovenia \\
\hline
\end{tabular}


Cholevinae

Cholevinae

Cholevinae

Cholevinae

Cholevinae

Cholevinae

Cholevinae

Cholevinae

Cholevinae

Cholevinae

Cholevinae

Cholevinae

Cholevinae

Cholevinae

Cholevinae

Cholevinae

Cholevinae

Cholevinae

Cholevinae

Cholevinae

Cholevinae

Cholevinae

Cholevinae

Cholevinae

Cholevinae

Cholevinae

Cholevinae

Cholevinae

Cholevinae

Cholevinae

Cholevinae

Cholevinae

Cholevinae

Cholevinae

Cholevinae
Bathysciina

Bathysciotina

Leptodirin

Leptodirin

Leptodirini

Leptodirini

Leptodirini

Leptodirin

Leptodirini

Leptodirini

Leptodirini

Leptodirini

Leptodirini

Leptodirini

Leptodirini

Leptodirini

Leptodirini

Leptodirini

Leptodirini

Leptodirini

Leptodirini

Leptodirini

Leptodirini

Leptodirini

Leptodirin

Leptodirini

Leptodirini

Leptodirini

Leptodirini

Leptodirini

Leptodirini

Leptodirini

Leptodirini

Leptodirini

Oritocatopini

Oritocatopini

Leptodirina

Leptodirina

Leptodirina

Leptodirina

Leptodirina

Leptodirina

Leptodirina

Leptodirina

Leptodirina

Pholeuina

Pholeuina

Pholeuina

Pholeuina

Pholeuina

Pholeuina

Pholeuina

Pholeuina

Pholeuina

Pholeuina

Pholeuina

Pholeuina

Pholeuina

Pholeuina

Pholeuina

Pholeuina

Platycholeina

Platycholeina

Spelaeobatina
Pisidiella kosswigi Jeannel

Bathysciotes khevenhuelleri tergestinus Müller

Bathysciotina Neobathyscia fabianii (Dodero)

Bathysciotina Ravasinia lonae (Müller)

Bathysciotina Speonesiotes $s p$

Antrosedes speluncarius Reitter

Apholeuonus longicollis Reitter

Astagobius angustatus laticollis Pretner

Elladoherpon inopinatum Casale

Haplotropidius pubescens (Müller)

Leptodirus hochenwarti Schmidt

Pholeuonidius halbherri (Reitter)

Remyella scaphoides droveniki Giachino \&

Etonti

Speoplanes giganteus biocovensis (Müller)

Albaniola thessalica (Reitter)

Antrocharis querilhaci (Lespès)

Beskovia bulgarica Guéorguiev

Breuilia triangulum (Sharp)

Canavesiella lanai Giachino

Dellabeffaella roccae (Capra)

Notidocharis ovoideus Jeannel

Parabathyscia (Parabathyscia) ligurica

(Reitter)

Paraspeonomus vandeli Coiffait

Paratroglophyes jeanneli Coiffait

Pholeuon knirschi Breit

Pseudoboldoria robiati (Reitter)

Quaestus arcanus Schaufuss

Speonomus (Machaeroscelis) infernus (Dieck)

Troglocharinus ferreri (Reitter)

Troglodromus bucheti caussicola Jeannel

Platycholeus leptinoides (Crotch)

Platycholeus opacellus Fall

Spelaeobates kraussi Müller

Afrocatops sp.

Chappuisiotes lobeliae Jeannel
Hacı Akif, Beyşehir Gölü, Konya, Turkey

Trieste, Friuli Venezia Giulia, Italy

Buso della Rana, Monte di Malo, Vicenza, Veneto, Italy

Mount Tomorr, Berat, Albania

Pavlova pećina, Trebinje, Bosnia and Herzegovina

Bjelašnica, Bosnia and Herzegovina

Bjelašnica, Bosnia and Herzegovina

Ledenica pri Dolu, Trnovski gozd, Littoral, Slovenia

Seli, Naousa, Imathia, Greece

Vrlika, Split-Dalmatia, Croatia

Grotta Noè, Trieste, Friuli Venezia Giulia, Italy

Campone, Tramonti di Sotto, Friuli-Venezia Giulia, Italy

Pešter, Raška, Serbia

Ledenica pri Dolu, Trnovski gozd, Littoral, Slovenia

Spiliá, Mount Ossa, Larissa, Greece

Grotte de Font Sainte, Ariège, France

Cherepishka, Peshtera, Pazardzhik, Bulgaria

Cueva del Escosu, Pelamoru, Asturias, Spain

Grotta La Custreta, Sparone, Piemonte, Italy

Grotte di Pugnetto, Alpi Graie, Valli di Lanzo, Piemonte,

Italy

Fonte das Covas, Oballo-Boal, Asturias, Spain

Tana do Scovero, Castelbianco, Liguria, Italy

Faille de Jouandet, Ariège, France

Grottes d'Anglade, Ariège, France

Hoanca Apei, Valea Gardei Seci, Bihor Mt, Romania

Crepaccio di Paderno, Paderno d'Adda, Lombardia, Italy

Cueva de la Matona, Comillas, Cantabria, Spain

Haute-Garonne, France

(a) Avenc d'en Roca, Cervelló; (b) Vallirana: Barcelona,

Spain

Peille, Alpes-Maritimes, France

Pacific House, El Dorado, California, USA

Stanislaus, Calaveras, California, USA

Dobra jama, Split-Dalmatia, Croatia

Cathedral Peak Forest Station, KwaZulu-Natal, South Africa

Koitobos, Mount Elgon, Kenya 
Cholevinae

Cholevinae

Cholevinae

Cholevinae

Cholevinae

Cholevinae

Cholevinae

Cholevinae

Cholevinae

Cholevinae

Cholevinae

Cholevinae

Cholevinae

Cholevinae

Camiarinae

Camiarinae

Camiarinae

Camiarinae

Catopocerinae

Leiodinae

Leiodinae

Leiodinae

Leiodinae

Leiodinae

Leiodinae

Platypsyllinae

AGYRTIDAE

Necrophilinae
Adelopsis leo Gnaspini

Adelopsis rostrata Gnaspini \& Peck

Amplexella dimorpha Gnaspin

Parapaulipalpina sp.

Paulipalpina claudicans (Szymczakowski)

Paulipalpina sp. 1

Paulipalpina sp. 2

Paulipalpina sp. 3

Ptomaphagus meximontanus Peck

Ptomaphagus sericatus Chaudoir

Ptomaphagini Ptomaphagin

Ptomaphagini Ptomaphagina

Ptomaphagini Ptomaphaginina

Ptomaphagini Ptomaphaginina

Ptomaphagini Ptomaphaginina

Ptomaphaginus palpalis Szymczakowski

Ptomaphaminus chapmani (Peck)

Proptomaphaginus puertoricensis Peck

Sciaphyes sibiricus (Reitter)

Agyrtodes labralis (Broun)

Eupelates transversestrigosus (Fairmaire \&

Germain)

Camiarus thoracicus Sharp

Neopelatops edwardsi Jeannel

Catopocerus politus Motschulsky

Decuria sp.

Dietta huanuco Peck \& Cook

Zeadolopus validipes (Daffner)

Colenisia zelandica Leschen

Hydnodiaetus sp.

Scotocryptus sp.

Leptinus testaceus P.W.J. Müller
Iporanga, São Paulo, Brazi

Monteverde, Puntarenas, Costa Rica

Rancho Grande, Aragua, Venezuela

Sipao, 110kmE Caicara, Bolívar, Venezuela

Nova Teutônia, Santa Catarina, Brazil

Mérida, Mérida, Venezuela

Colonia Tovar, Aragua, Venezuela

Leticia, Amazonas, Colombia

Pinal de Amoles, Querétaro, Mexico

Trebnje, Trebnje, Lower Carniola, Slovenia

Phulchoki, Kathmandu, Nepal

Clearwater cave, Gunung Mulu, Sarawak, Malaysia

Aguas Buenas Cave, Aguas Buenas, Puerto Rico

Vladivostok, Primorsky Krai, Russia

Matukituki Valley, New Zealand

Alto de Nahuelbuta, Arauco, Bío Bío, Chile

Maraetai Hills, Auckland, New Zealand

Osorno, Osorno, Chile

Witmer, Pendleton County, West Virginia, USA

Puerto Maldonado, Tambopata, Madre de Dios, Peru

Tingo María, Cordillera Azul, Peru

Hunua Ra Mangatangi, Auckland, New Zealand

Te Paki, Northland, New Zealand

Manzanar, Malleco, Araucanía, Chile

Viçosa, Minas Gerais, Brazil

Giare, Veneto, Italy

Takitimu, Princhester Hut, Southland, New Zealand 
Figure legends

Fig. 1. Head, ventral view. (a) Anemadus acicularis (Anemadini). (b) Camiarus thoracicus (Camiarinae). (c) Catops fuliginosus (Cholevini). (d) Eucatops sp. 2 (Eucatopini). (e) Colenisia zealandica (Leiodinae). (f) Paraspeonomus vandeli (Leptodirini). (g) Ptomaphagus sericatus (Ptomaphagini). (h) Chappuisiotes lobeliae (Oritocatopini). arm, anterior ridge of mentum; hs, hypostomal suture; lrm, longitudinal ridge of mentum; pmr, postmandibular ridge.

Fig. 2. Mouthparts, ventral view. Ventral surface of prementum of (a) Eocatops ophidianus (Anemadini), (b) Afrocatops sp. (Oritocatopini), (c) Paracatops antipoda (Anemadini), and (d) Choleva oblonga (Cholevini). Labial palp of (e) Prionochaeta harmandi (Cholevini) and (f) Agyrtodes labralis (Camiarinae). Maxillary palp of (g) Chappuisiotes lobeliae (Oritocatopini), (h) Nargus velox (Cholevini), (i) Camiarus thoracicus (Camiarinae), and (j) Ptomaphaginus palpalis (Ptomaphagini). pmt, prementum.

Fig. 3. Apical maxillary palpomere of (a) Rybinskiella magnifica (Cholevini), (b) Platycholeus opacellus (Leptodirini), and (c) Quaestus arcanus (Leptodirini). dgts, digitiform sensilla; ps, projecting sensilla.

Fig. 4. Subapical maxillary palpomere of Speonemadus bolivari. Arrows indicate pore plates.

Fig. 5. Central area of the frontoclypeal surface in (a) Zeanecrophilus prolongatus (Agyrtidae), (b) Colenisia zealandica (Leiodinae), (c) Rybinskiella magnifica (Cholevini), and Eucatops sp. 2 (Eucatopini). Vertex of (e) Neopelatops edwarsi (Camiarinae) and (f) Pseudonemadus cheesmani (Anemadini). sa, setal areola.

Fig. 6. Dorsal view of anterior margin of clypeus in (a) Cholevinus fuscipes (Cholevini) and (b) Dellabefaela roccae (Leptodirini). Frontal view of clypeus of (c) Speonemadus bolivari (Anemadini) and (d) Ptomaphagus meximontanus (Ptomaphagini). Dorsal view of head of (e) Eupelates transversistrigosus (Camiarinae) and (f) Eucatops sp. 1 (Eucatopini). Lateral view of head of (g) Agyrtodes labralis (Camiarinae) and (h) Catops fuliginosus (Cholevini). arc, anterior ridge of clypeus; fsr, frontoclypeal strengthening ridge; or, elevated transverse occipital ridge; pogf, postocular genal fold.

Fig. 7. Partial ventral view of head of (a) Agyrtodes labralis (Camiarinae) and (b) Ptomaphagus sericatus (Ptomaphagini). Partial frontal view of head of (c) Colenisia zelandica (Leiodinae), and (d) Eocatops ophidianus (Anemadini). or, elevated transverse occipital ridge; pogf, postocular genal fold.

Fig. 8. Protorax, ventral view. (a) Zeanecrophilus prolongatus (Agyrtidae). (b) Eucatops sp. 2 (Eucatopini). (c) Rybinskiella magnifica (Cholevini). lopc, lateral opening of procoxal cavity; mnp, medial notch of the prosternal process; pph, postcoxal projection of hypomeron; vdp, ventrally directed projection of the prosternum.

Fig. 9. Pterothorax, ventral view. (a) Eucatops sp. 2 (Eucatopini). (b) Afrocatops (Oritocatopini). (c) Sciodrepoides watsoni (Cholevini). (d) Paracatops antipoda. (e) Ptomaphagus sericatus (Ptomaphagini). (f) Oryotus schmidti (Leptodirini). The white arrow indicates the suture between 
mesanepisternum and mesoventrite. The black arrow indicates the suture between mesanepisternum and mesepimeron. as, anapleural suture; mc, metaventral carina; mlc, median longitudinal carina; mset, mesanepisternum; msp, mesepimeron; msv, mesoventrite; mtet, metanepisternum; mtv, metaventrite; mtvp, metaventral process.

Fig. 10. Pterothorax. (a) Colenisia zelandica (Leiodinae), vetrolateral view. (b) Camiarus thoracicus (Camiarinae), ventral view.

Fig. 11. Pterothorax, ventrolateral view. (a) Anemadus acicularis (Anemadini). (b) Quaestus arcanus (Leptodirini). pcm, posteromesal corner of mesepimeron.

Fig. 12. Elytra, dorsal view. (a, e) Zeanecrophilus prolongatus (Agyrtidae). (b, f) Neopelatops edwarsi (Camiarinae). (c, g) Nemadus sp. (Anemadini). (d, h) Eucatops sp. 2 (Eucatopini).

Fig. 13. Detail of elytral surface, dorsal view. (a) Dissochaetus vanini (Anemadini). (b) Prionochaeta harmandi (Cholevini). (c) Catops fuliginosus (Cholevini). (d) Afrocatops (Oritocatopini). (e) Chappuisiotes lobeliae (Oritocatopini). (f) Quaestus arcanus (Leptodirini).

Fig. 14. Mesotarsi of males, ventral view. (a) Falkocholeva sp. (Anemadini). (b) Eocatops ophidianus (Anemadini).

Fig. 15. Mesotibial ventral spurs. (a) Eucatops sp. 1 (Eucatopini). (b) Amplexella dimorpha (Ptomaphagini). (c) Platycholeus leptinoides (Leptodirini). (d) Eocatops ophidianus (Anemadini). (e) Prionochaeta opaca (Cholevini). (f) Catops fuliginosus (Cholevini). (g) Dellabefaela roccae (Leptodirini). (h) Quaestus arcanus (Leptodirini). (i) Sciaphyes sibiricus (Sciaphyini).

Fig. 16. Pore plates in the terminal tarsomeres of Leptodirini. (a: arrows, b) Aphaobius milleri. (c) Antroherpon hoermani. (d) Ravasinia lonae. (e) Apholeuonus longicollis. (f) Astagobius angustatus. (g) Antrocharis querilhaci.

Fig. 17. Pretarsus of foreleg, ventral view. (a) Zeanecrophilus prolongatus (Agyrtidae). (b) Apocatops monguzi (Cholevini). (c) Dellabefaela roccae (Leptodirini). mpp, paired medial projections of the terminal tarsomere; rsmp, oblique row of spines on the medial projection of the terminal tarsomere.

Fig. 18. Pretarsi, ventral view. (a) Chappuisiotes lobeliae (Oritocatopini), foreleg. (b) Afrocatops sp., hind leg (Oritocatopini). esc, empodial esclerite; est, empodial seta; slp, spine-like projection close to the lateral margin of the terminal tarsomere.

Fig. 19. Unguitractor plate of middle leg, ventral view. (a) Parapaulipalpina sp. (Ptomaphagini). (b) Prionochaeta opaca (Cholevini). deup, distal extention of unguitractor plate; up, unguitractor plate.

Fig. 20. Empodium. (a, b) Adelopsis leo sp. (Ptomaphagini). (c) Ptomaphagus sericatus (Ptomaphagini). (d) Pseudonemadus cheesmani (Anemadini). (e) Nargiotes leptocerus (Anemadini). esc, empodial sclerite; est, empodial seta; ms, median sclerite. 
Fig. 21. Pretarsi of Leptodirini. (a, b) Ventral and frontal view of Hadesia vasiceki, respectively. (c) Canavesiela lanai. (d) Aphaobius milleri. cl, claw; est, empodial seta.

Fig. 22. Pretarsal structures. (a) Pretarsus of middle leg in Platycholeus leptinoides (Leptodirini), ventral view. (b) Pretarsus of hind leg in the same species, ventrolateral view. (c) Ventral and (d) dorsal view of empodial setae in Notidocharis ovoideus (Leptodirini). (e) Pretarsus of foreleg in Antrocharis querilhaci (Leptodirini), ventral view. (f) Pretarsus of foreleg in Paratroglophyes jeanelli (Leptodirini), ventral view. (g) Empodial setae of foreleg in Paraspeonomus vandeli (Leptodirini), lateral view. (h) Empodial setae of hind leg of Parabathyscia ligurica (Leptodirini), frontal view. (i) Ventral and (j) frontal view of pretarsus of hind leg in Catopsimorphus orientalis (Cholevini). White arrows $(\mathrm{c}-\mathrm{h})$ indicate the minute outer empodial seta found in some species of Leptodirini. Black arrows (i,j) indicate the characteristic knob-like structure present in most members of Cholevina. cl, claw; est, empodial seta; pesc, ventral projection of the empodial sclerite.

Fig. 23. Armature of claws. (a) Pseudonemadus cheesmani (Anemadini), lateral view, foreleg. (b) Ptomaphagus sericatus, lateral view, foreleg. (c) Adelopsis leo (Ptomphagini), frontal view, middle leg. (d) Sciaphyes sibiricus (Sciaphyini), lateral view, hind leg. cl, claw; sbc, lateral spines close to the base of the claws; sdc, spines on the basal dorsal surface of the claws; slc, spines on the basolateral surface of the claws; tc, row of strong teeth at the basolateral margin of the claws.

Fig. 24. Claws, dorsal view. (a) Zeanecrophilus prolongatus (Agyrtidae), foreleg. (b) Platycholeus leptonoides (Leptodirini) middle leg. (c) Sciaphyes sibiricus (Sciaphyini), middle leg. (d) Paratroglophyes jeanelli (Leptodirini), middle leg. tgc, transverse groove in the claw.

Fig. 25. Strict consensus tree derived from the parsimony analysis with equal weights. Node values represent Bremer Support. Colors in tree correspond to tribes of Cholevinae: purple = Oritocatopini, pink $=$ Eucatopini, green $=$ Anemadini, red $=$ Cholevini, brown $=$ Ptomaphagini, yellow $=$ Sciaphyini, blue $=$ Leptodirini .

Fig. 26. Strict consensus tree derived from the parsimony analysis with implied weights. Node values indicate the frequency of GC groups derived from symmetric resampling. Non-homoplastic changes in character states are represented with black circles, homoplastic changes with white circles.

Fig. 27. Majority consensus rule tree obtained in the Bayesian analysis. Numbers on nodes are posterior probabilities (nodes with a pp $<0.5$ are collapsed). Colors in tree correspond to tribes of Cholevinae (as in Fig. 25). 

CAPÍTULO 3

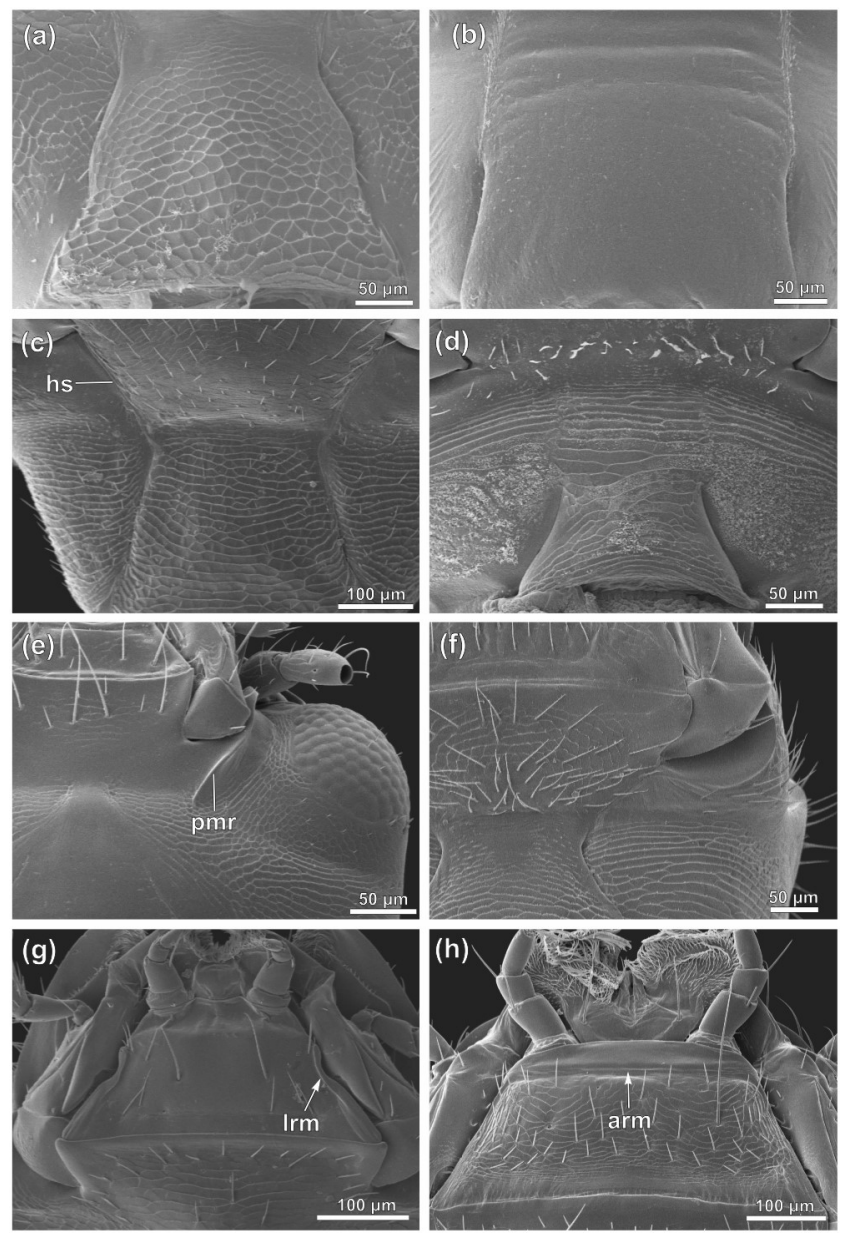

Fig. 1 


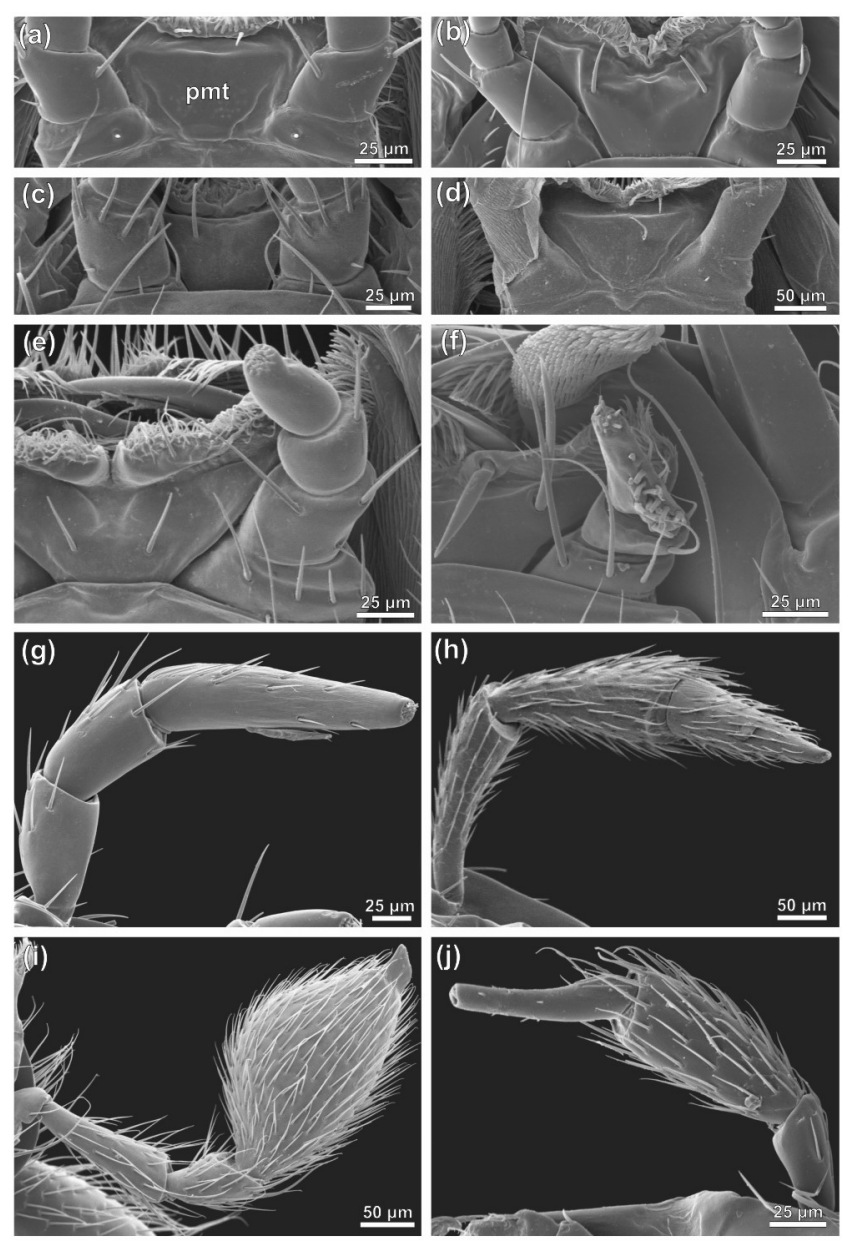

Fig. 2 


\section{CAPÍTULO 3}
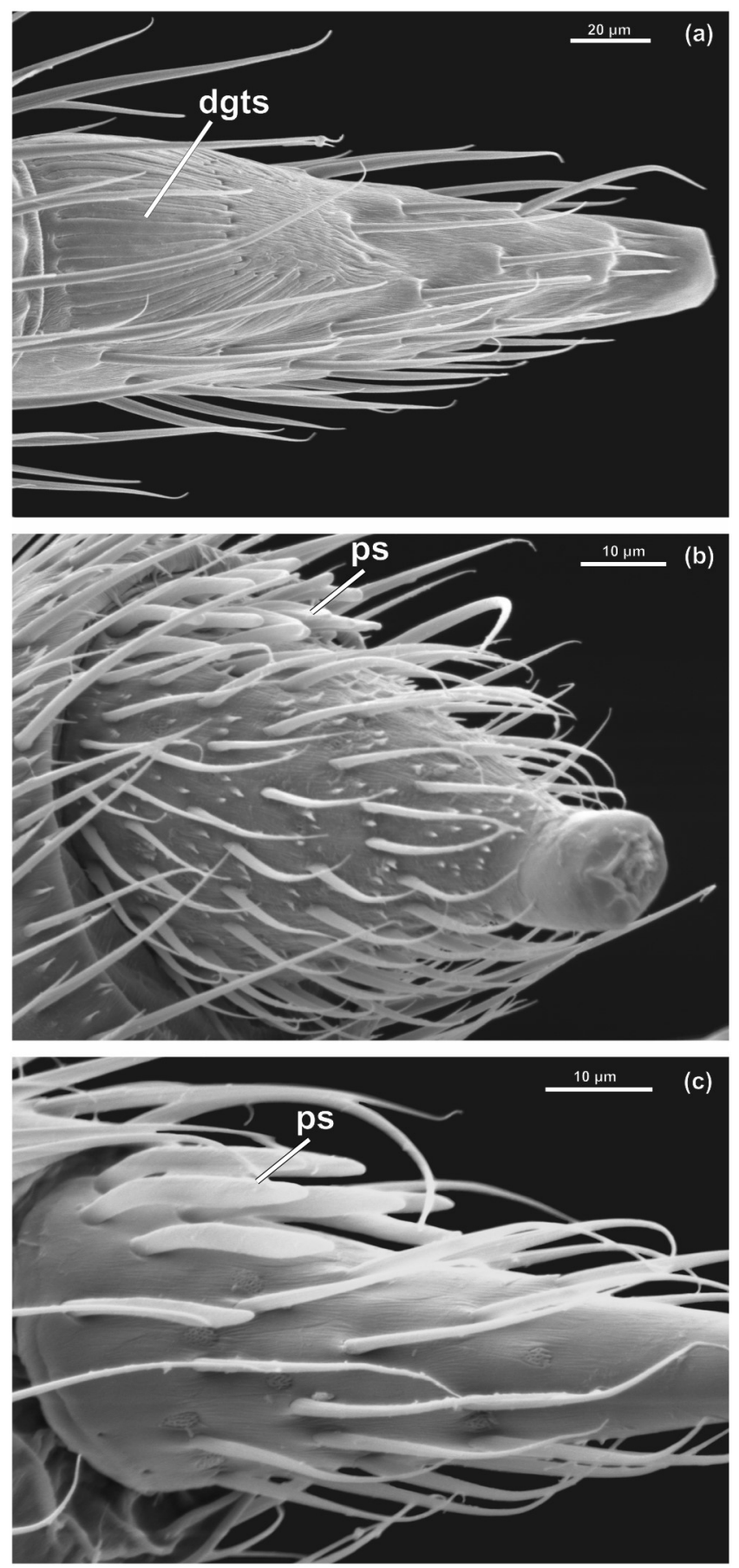

Fig. 3 

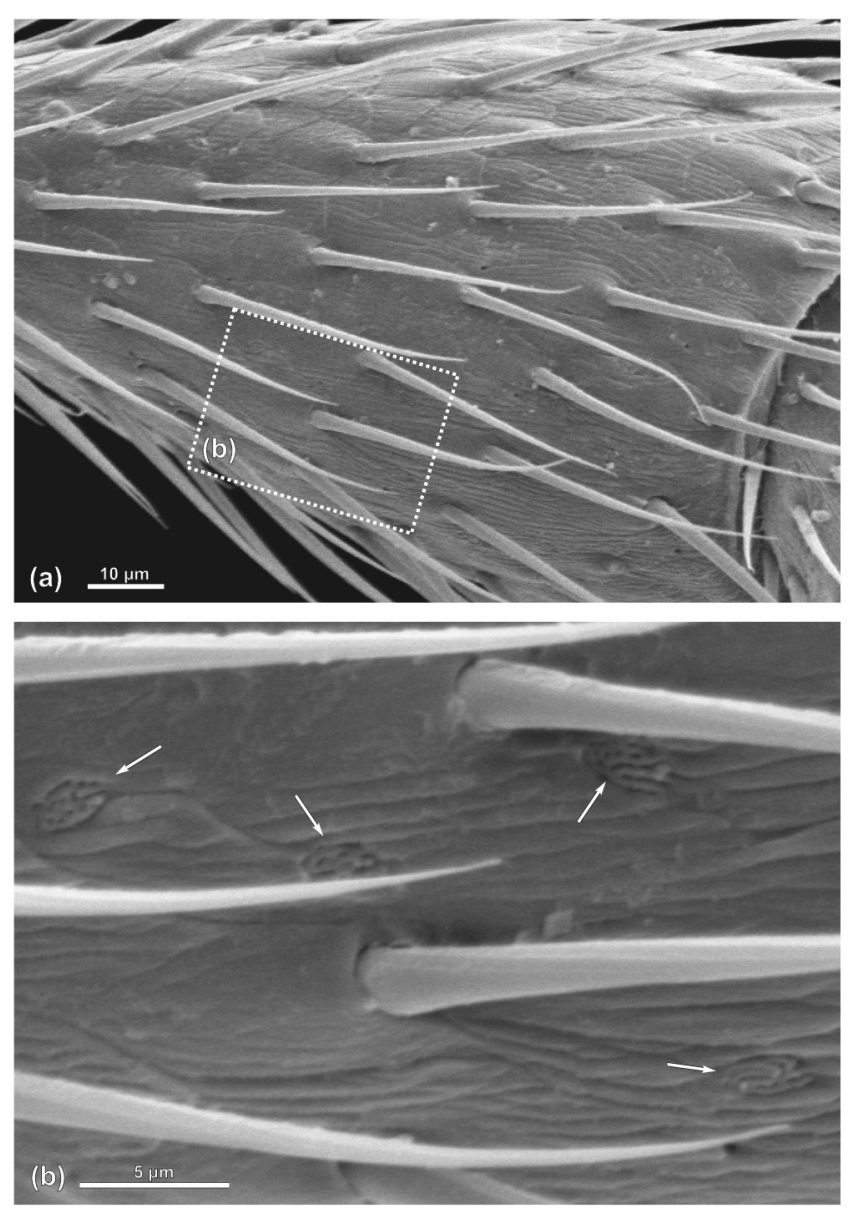

Fig. 4 
CAPÍTULO 3
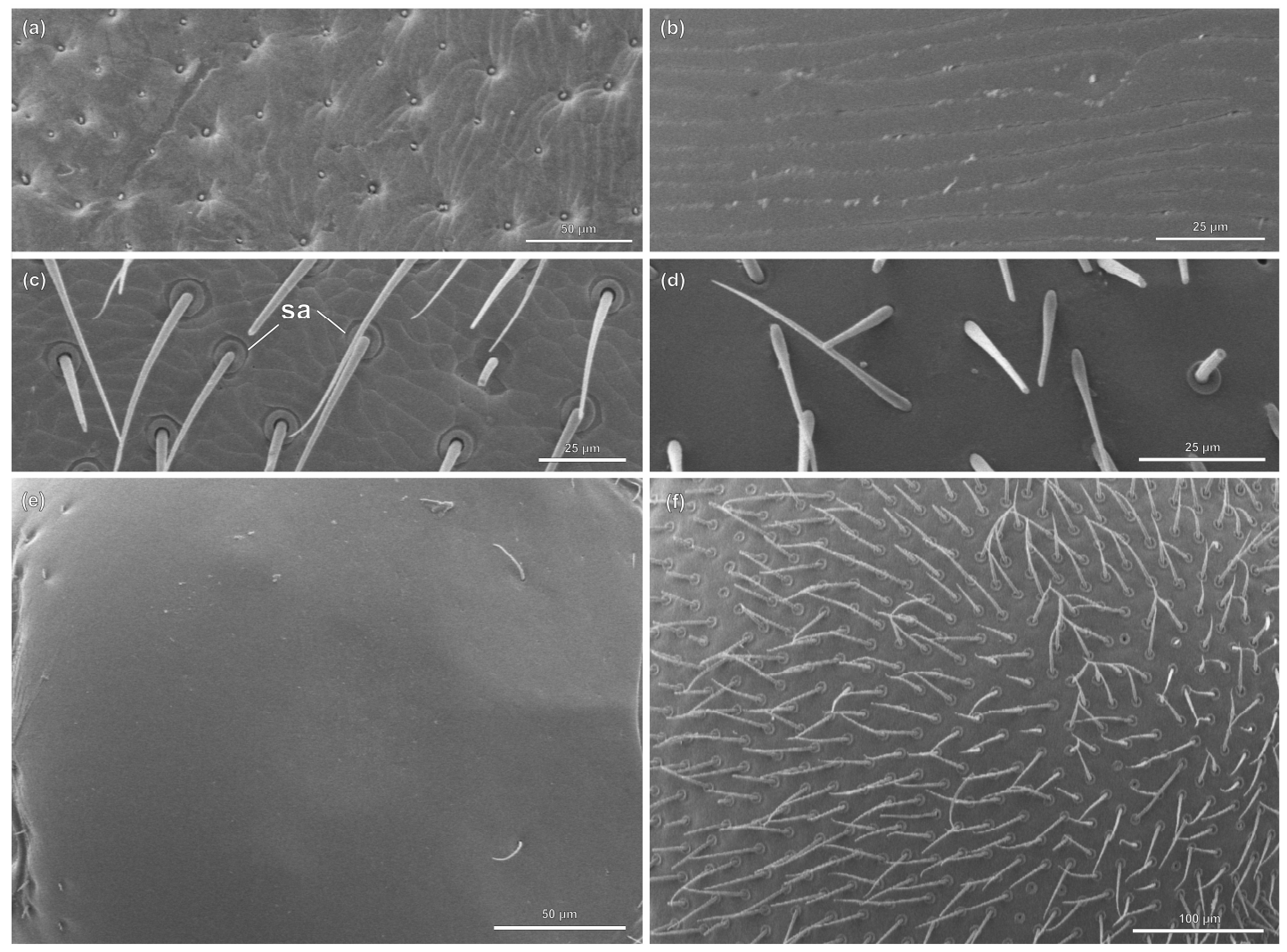

Fig. 5 
CAPÍTULO 3
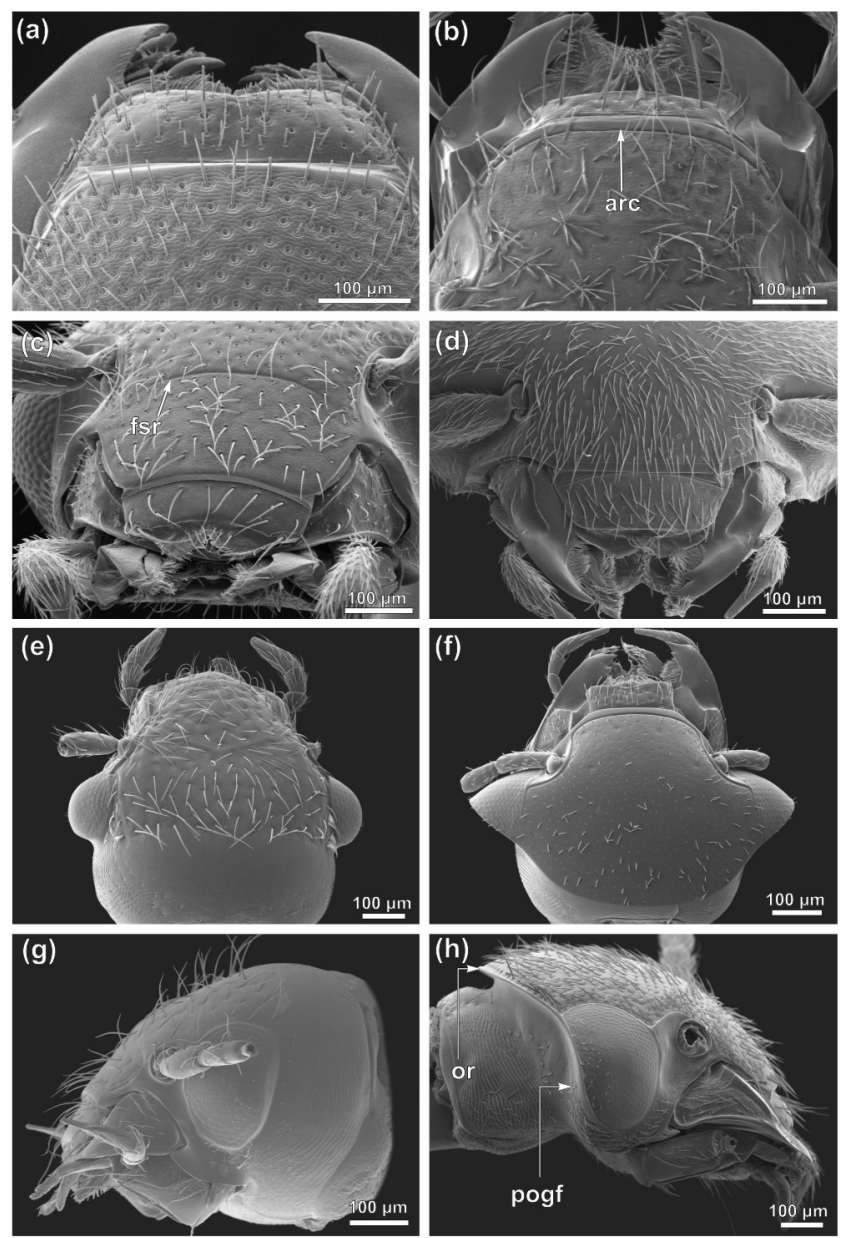

Fig. 6 
CAPÍTULO 3

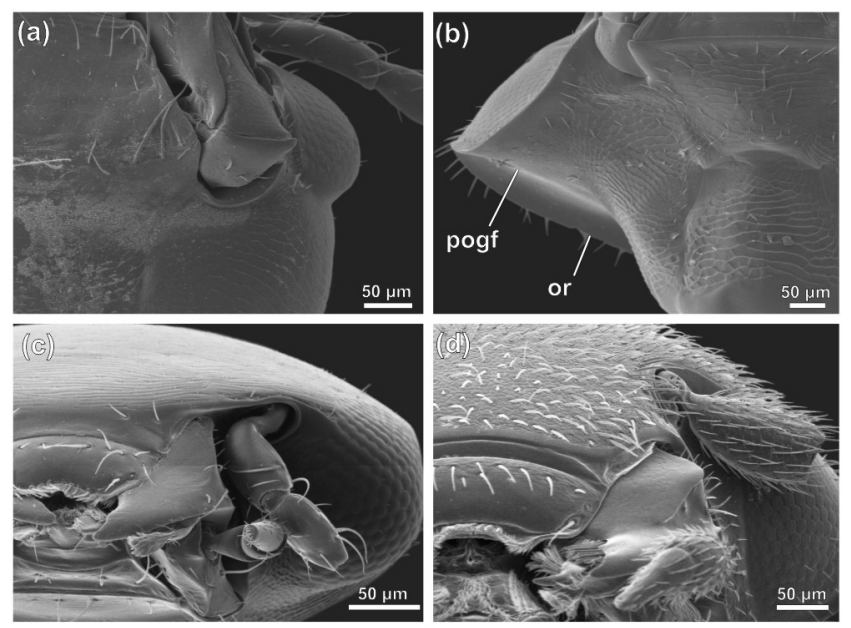

Fig. 7 

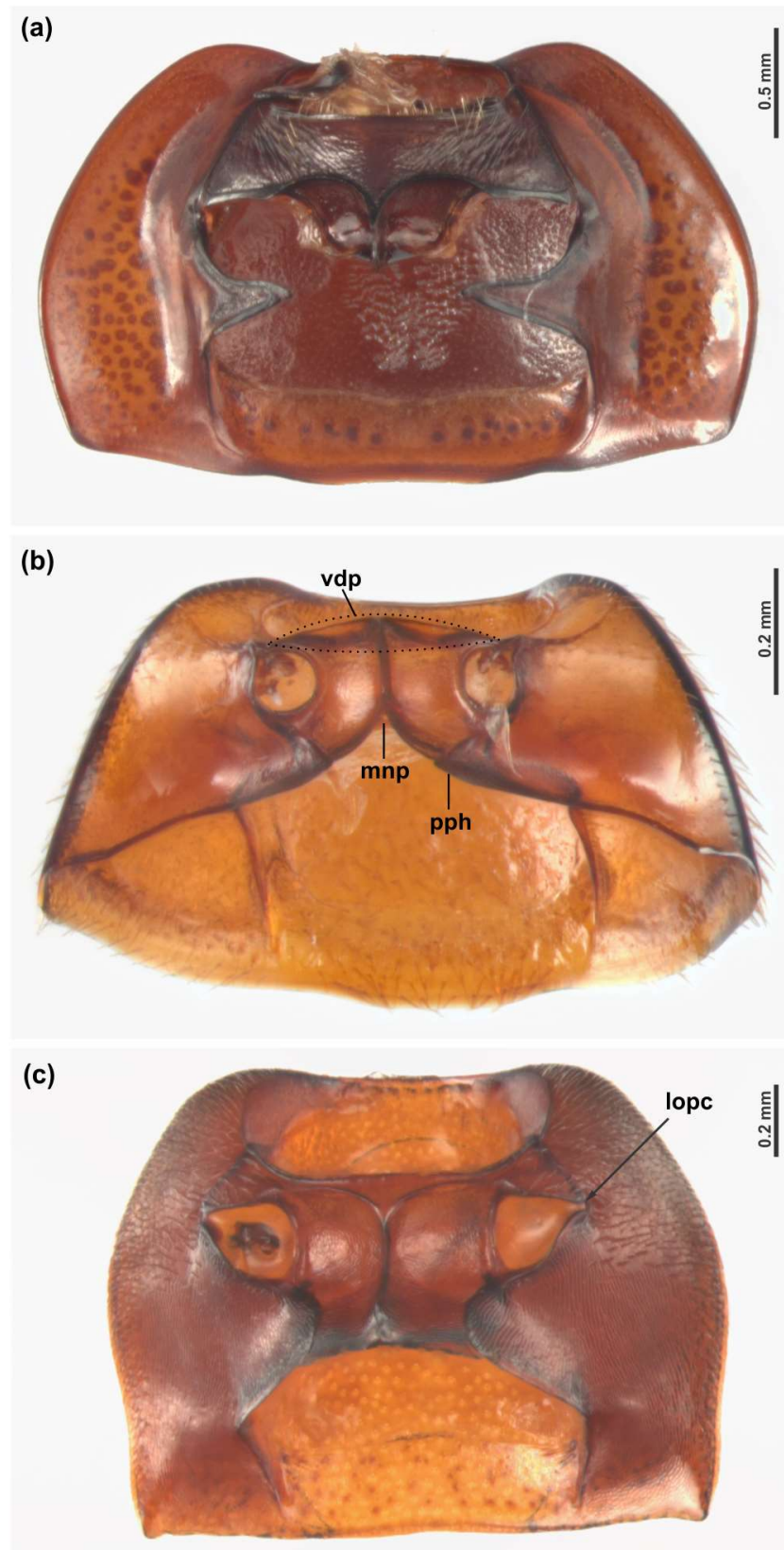

Fig. 8 
CAPÍTULO 3
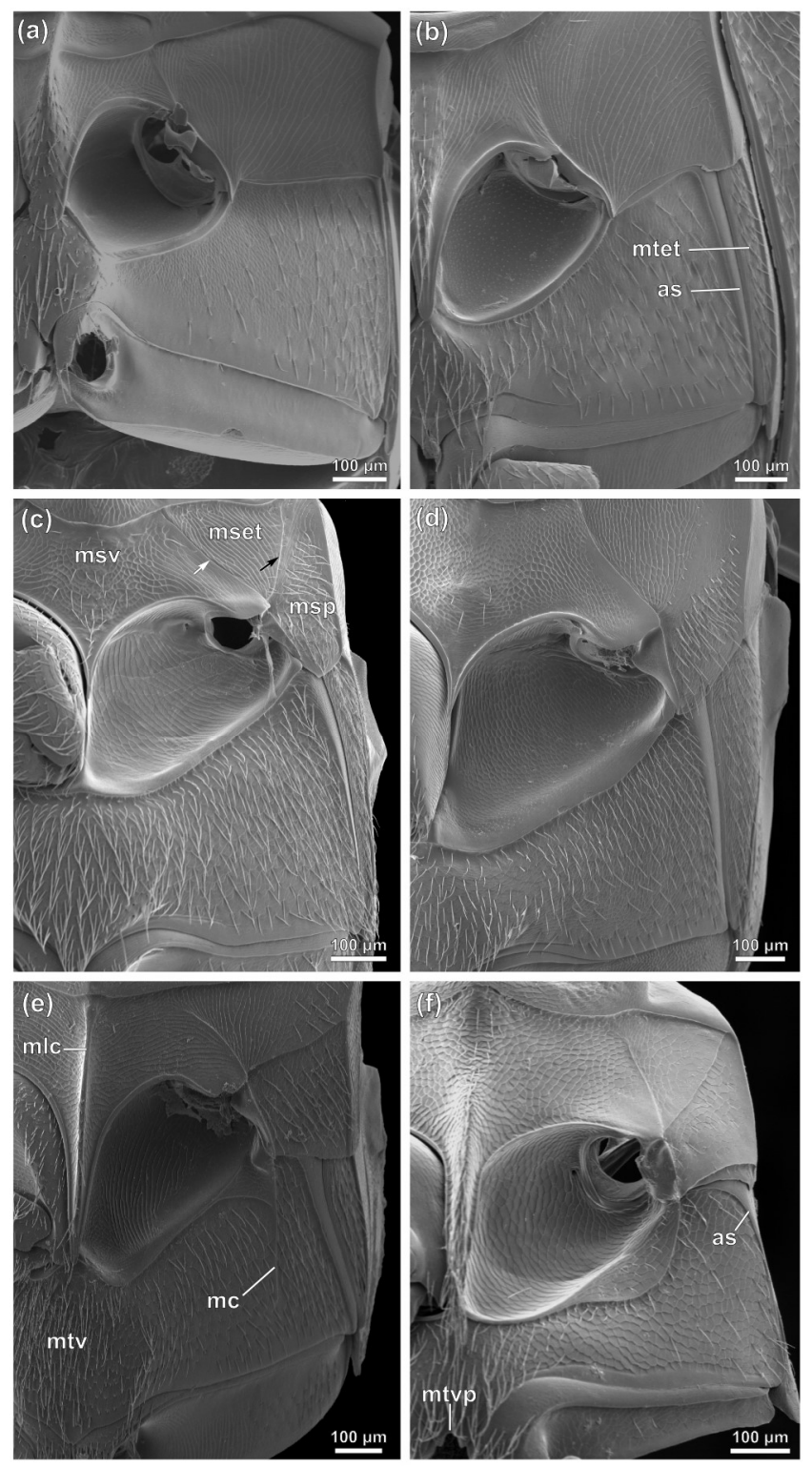

Fig. 9 
CAPÍTULO 3
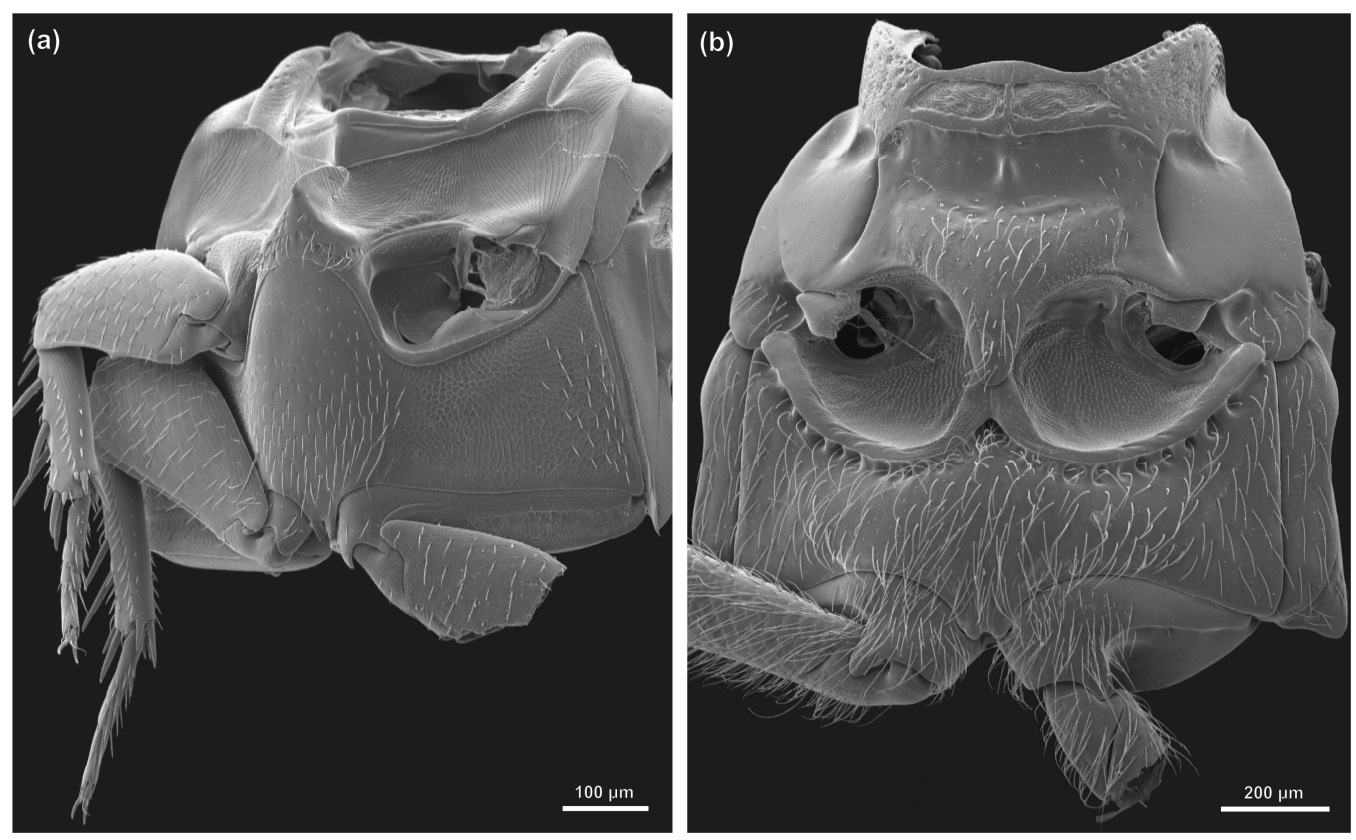

Fig. 10 
CAPÍTULO 3

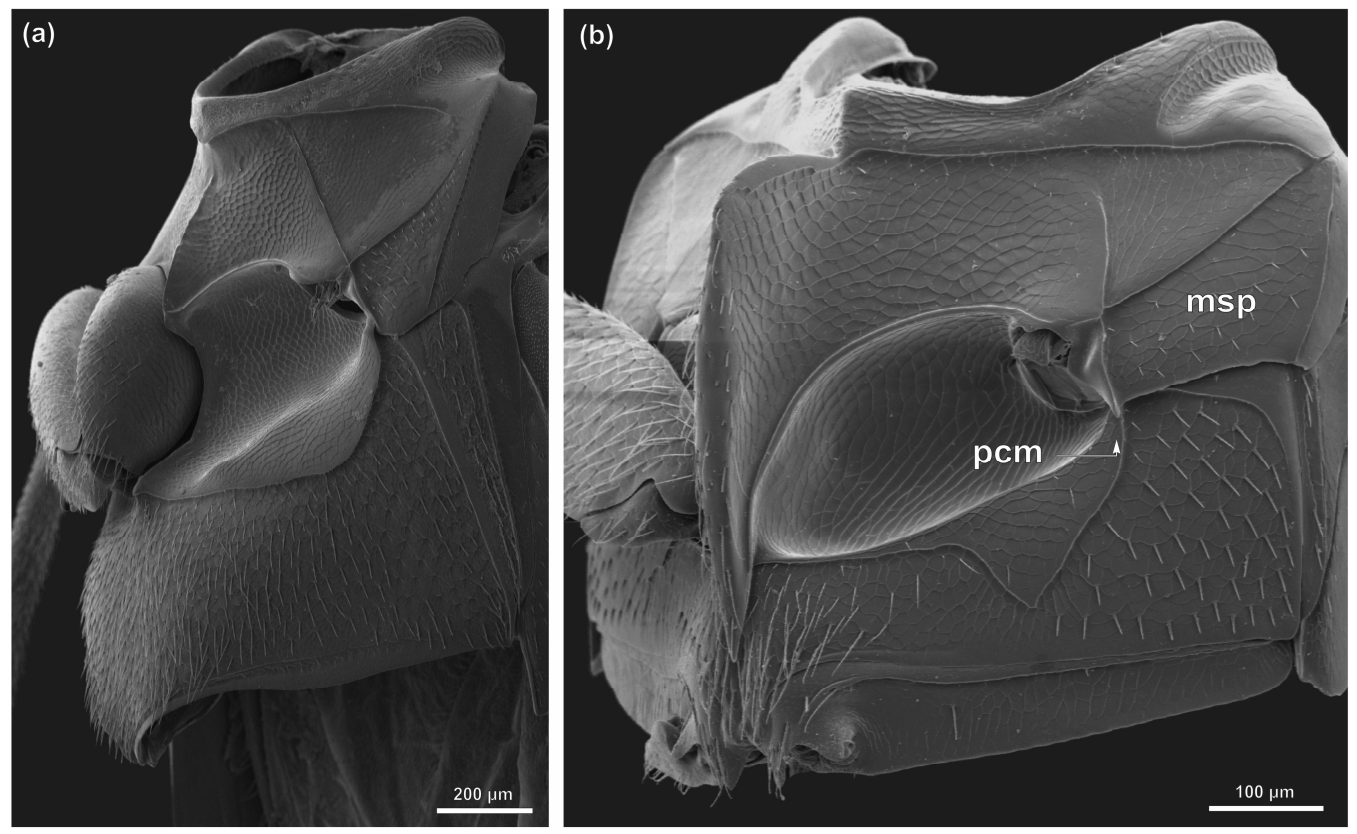

Fig. 11 


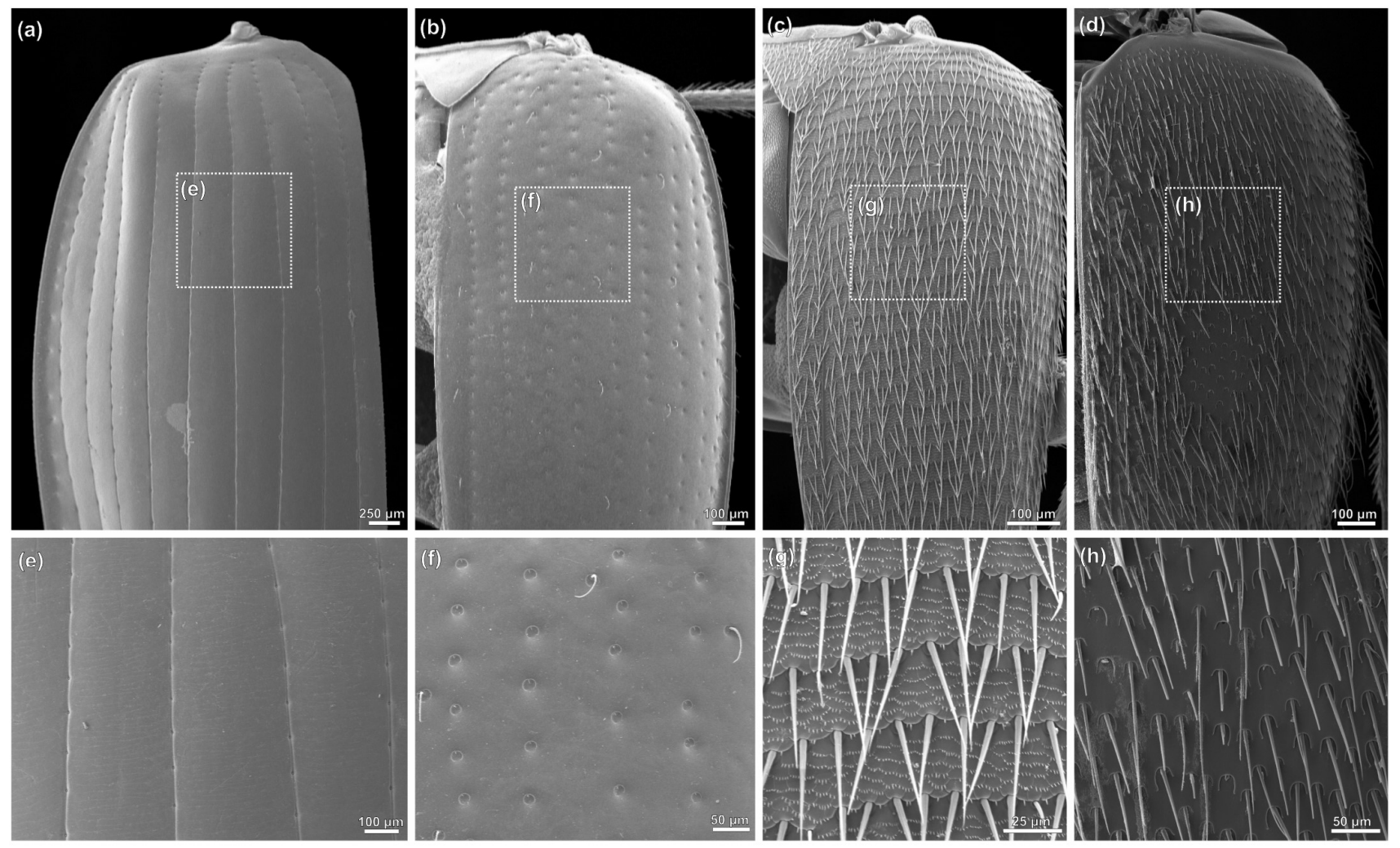

Fig. 12 
CAPÍTULO 3

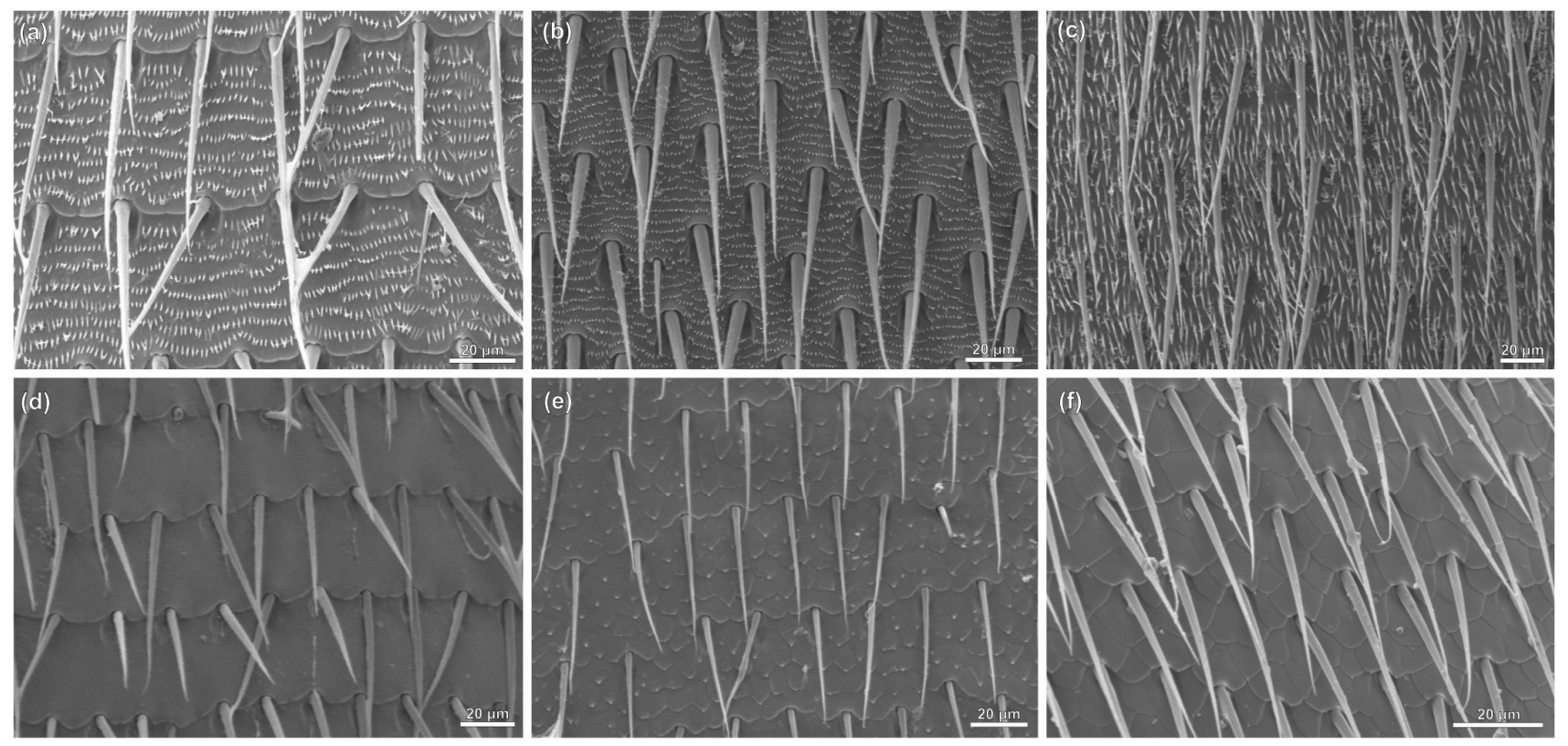

Fig. 13 


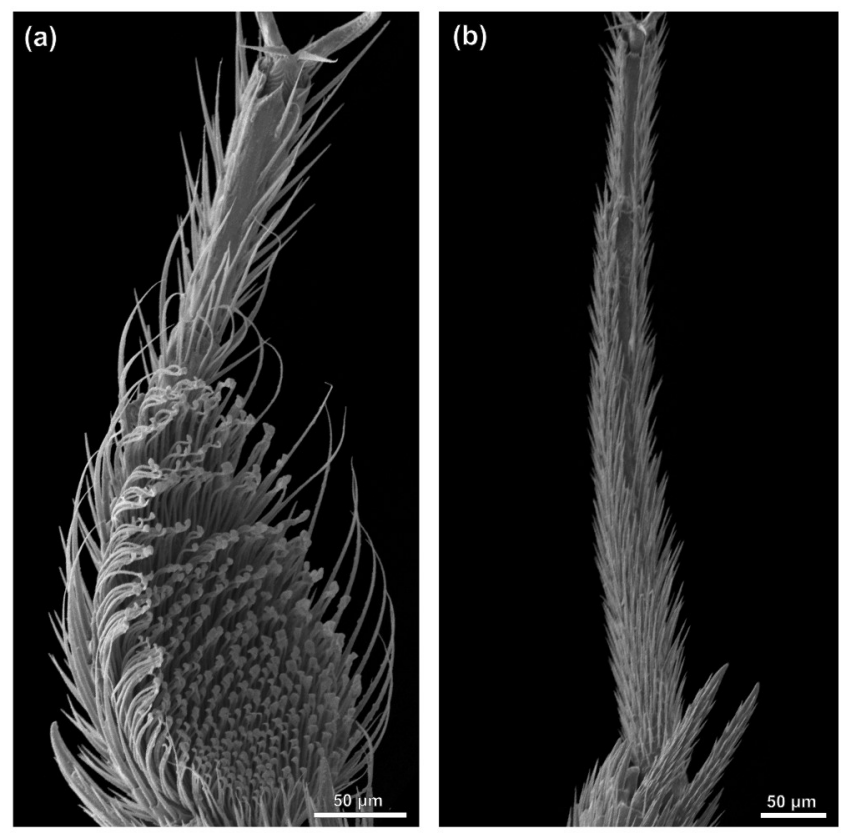

Fig. 14 
CAPÍTULO 3

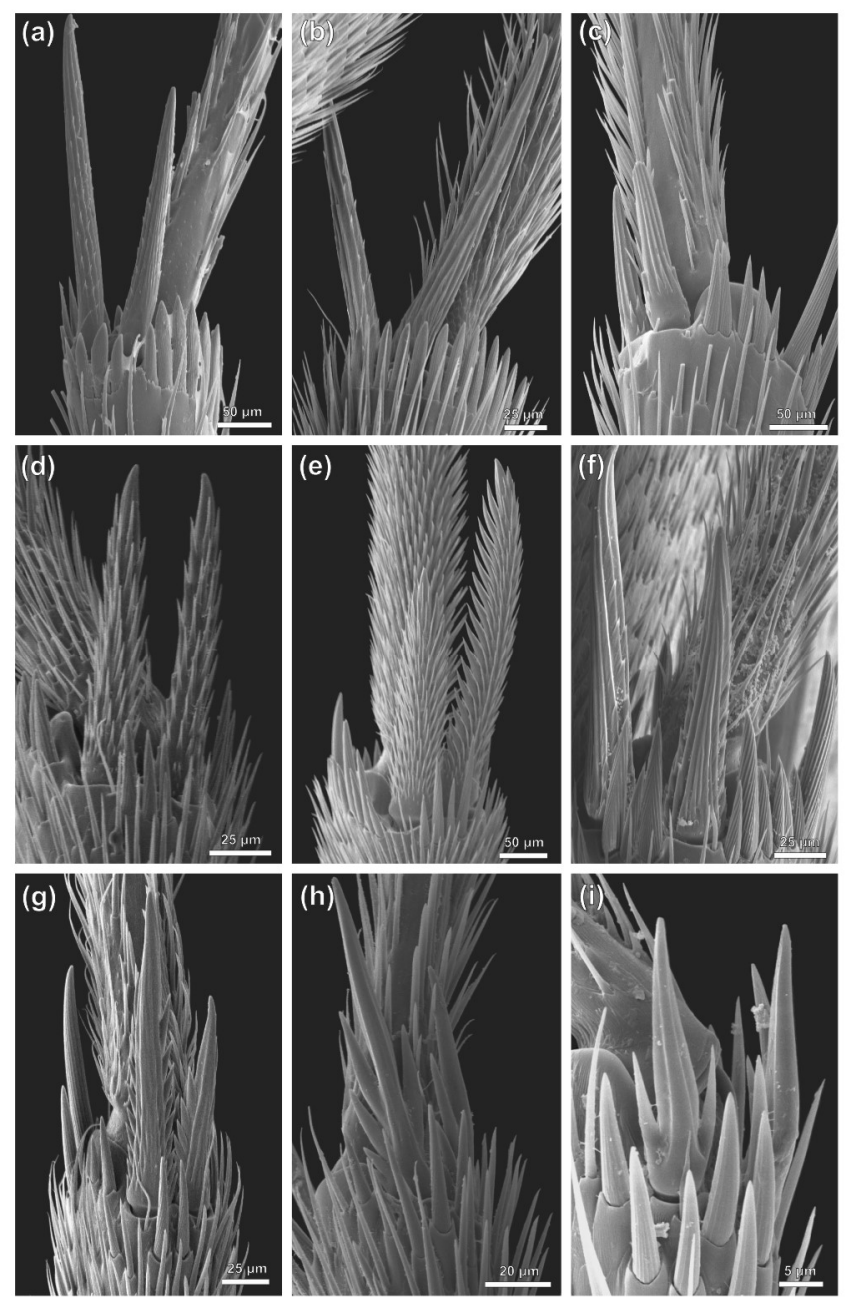

Fig. 15 
CAPÍTULO 3

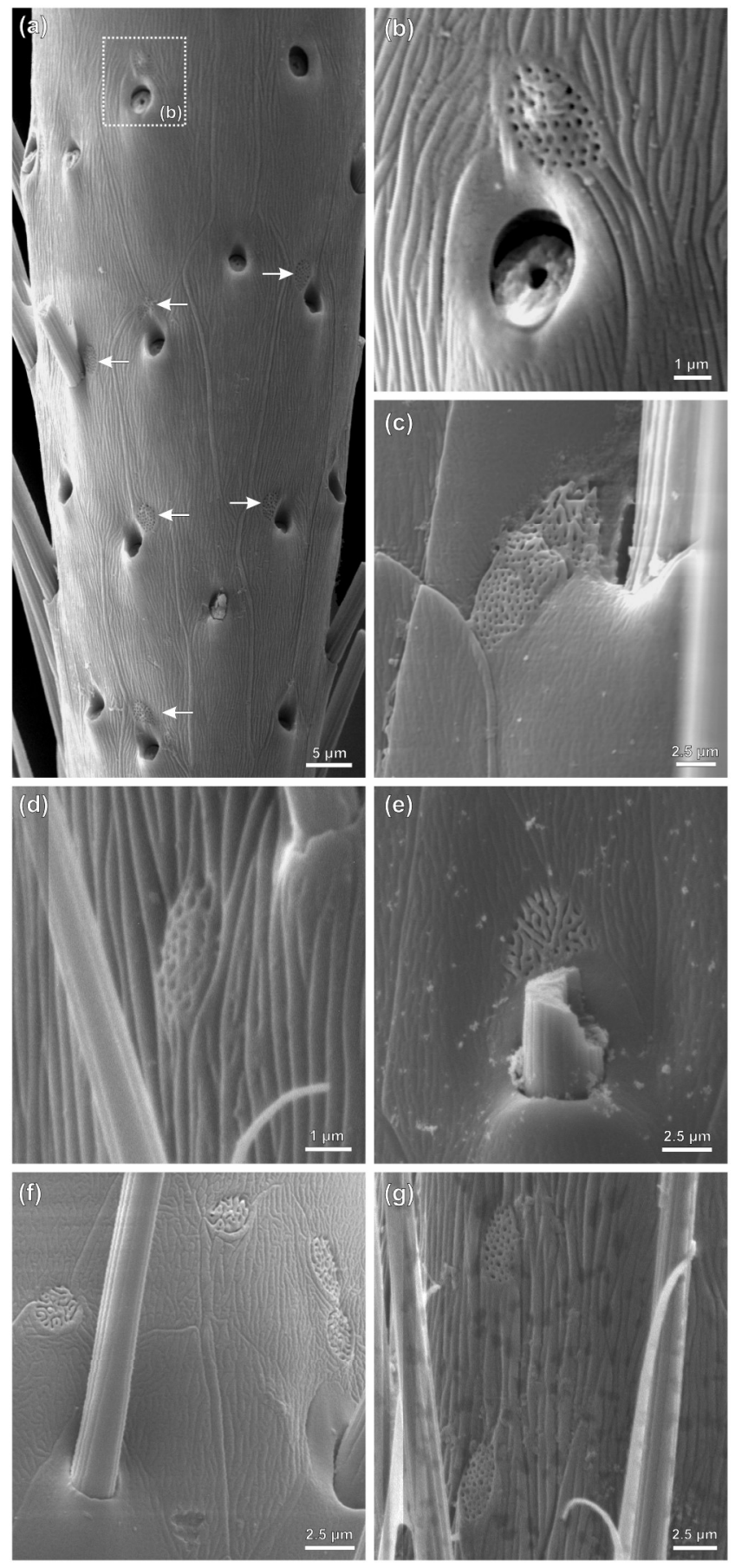

Fig. 16 
CAPÍTULO 3

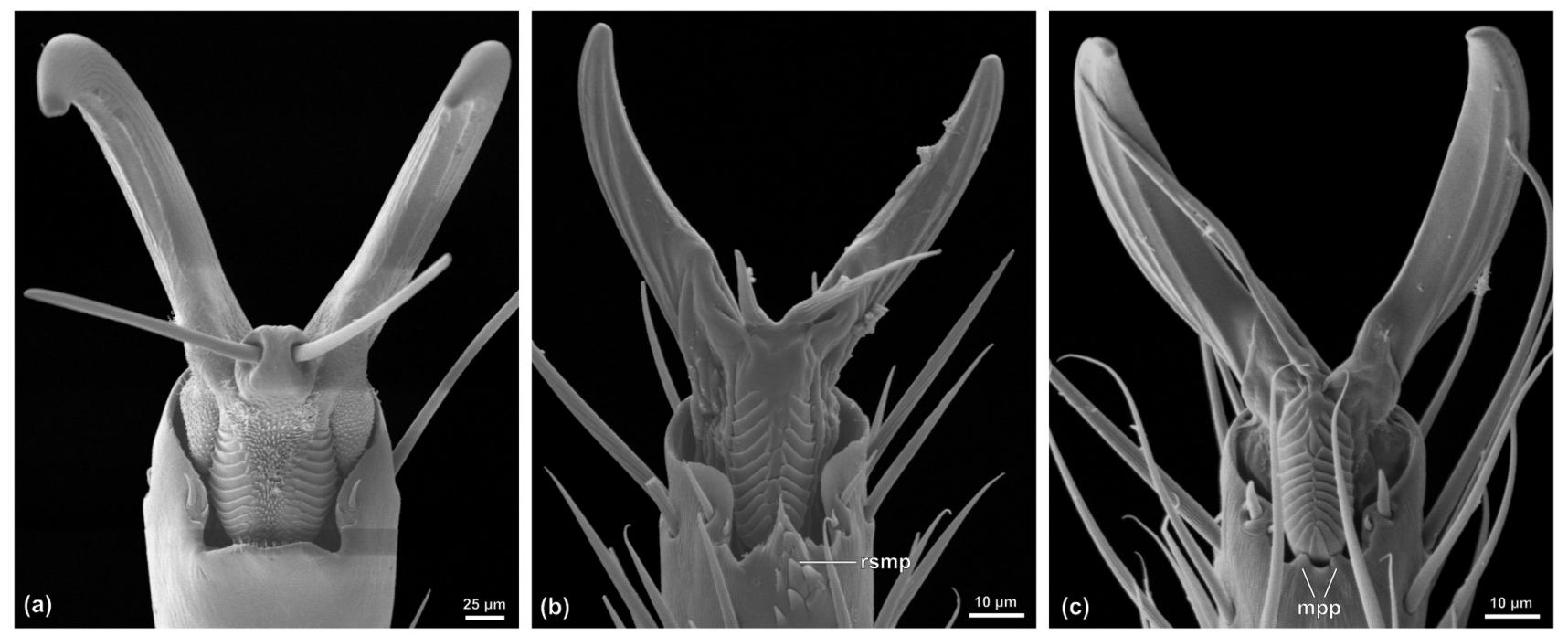

Fig. 17 
CAPÍTULO 3
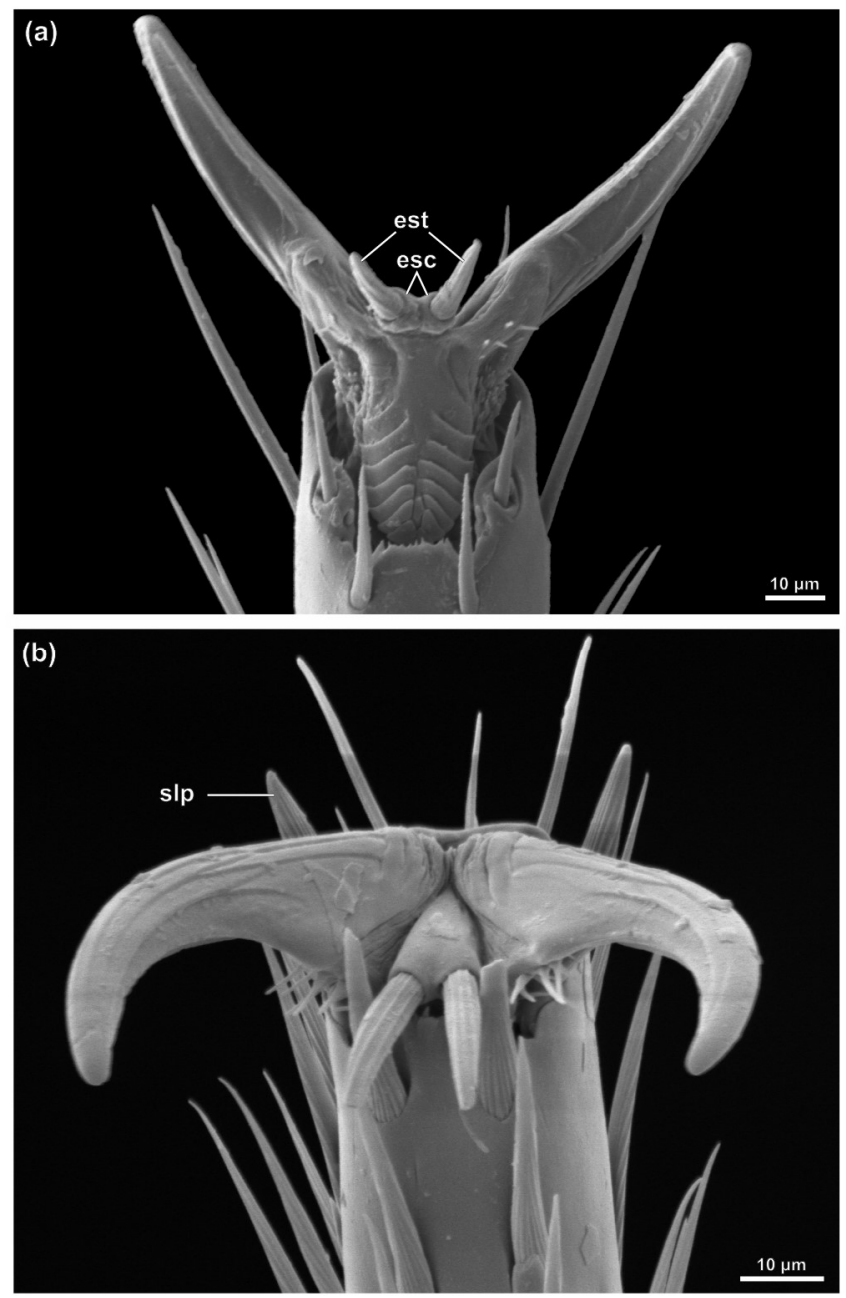

Fig. 18 
CAPÍTULO 3

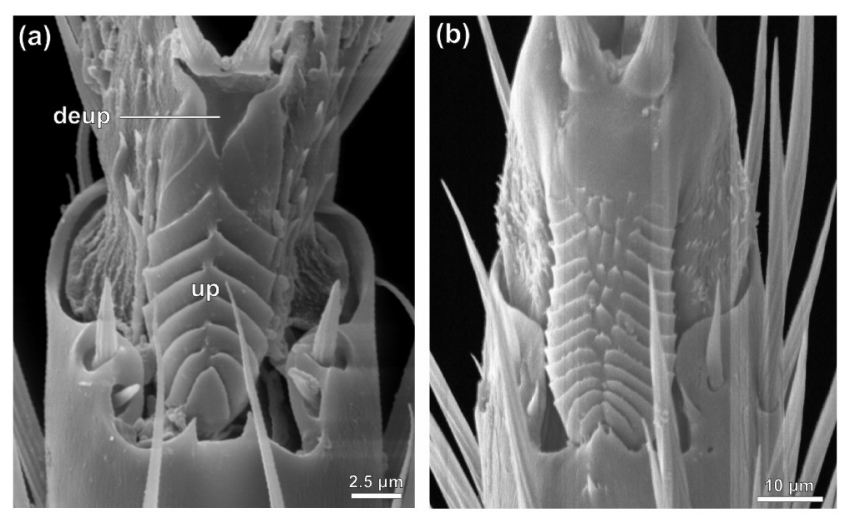

Fig. 19 
CAPÍTULO 3
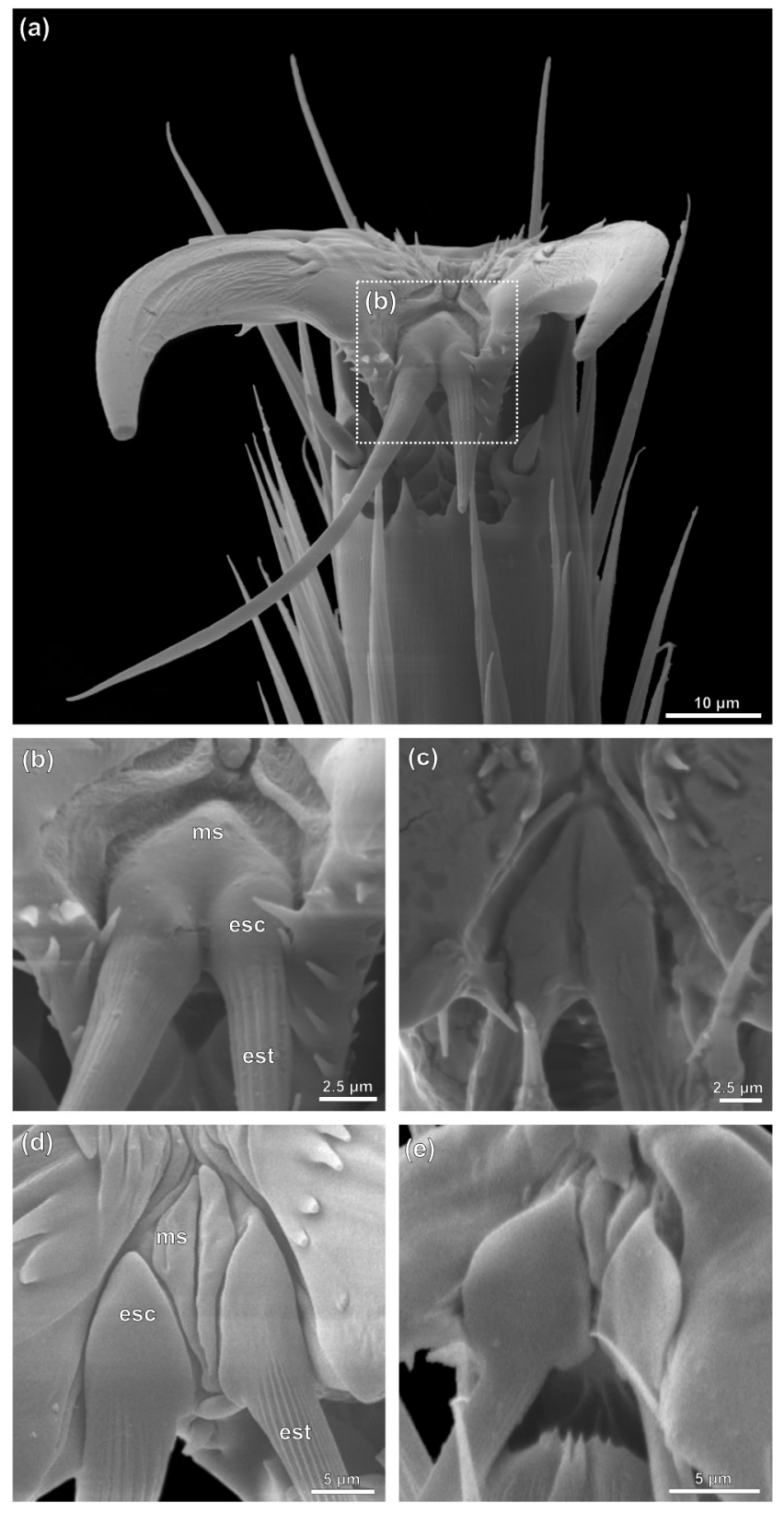

Fig. 20 

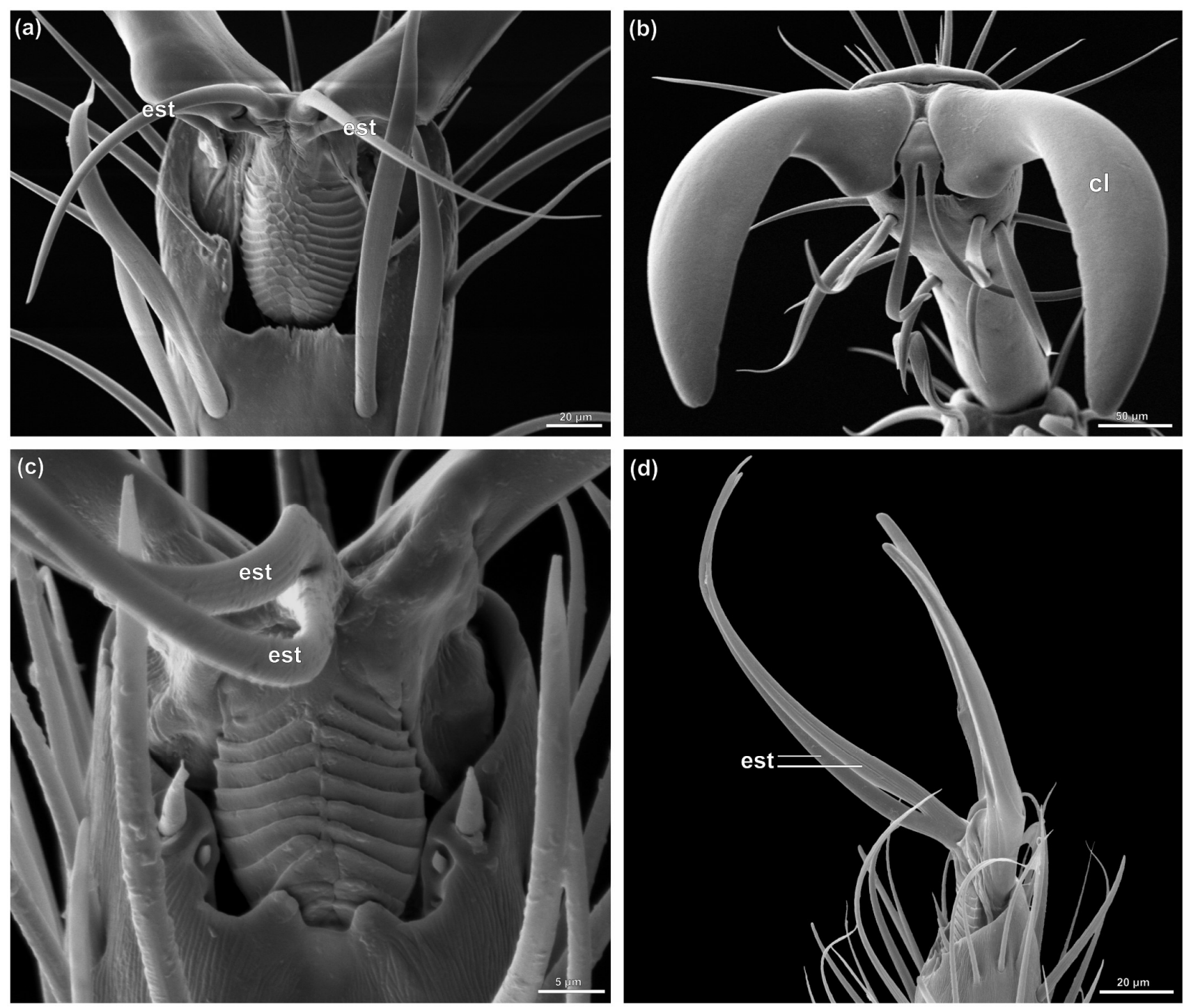

Fig. 21 

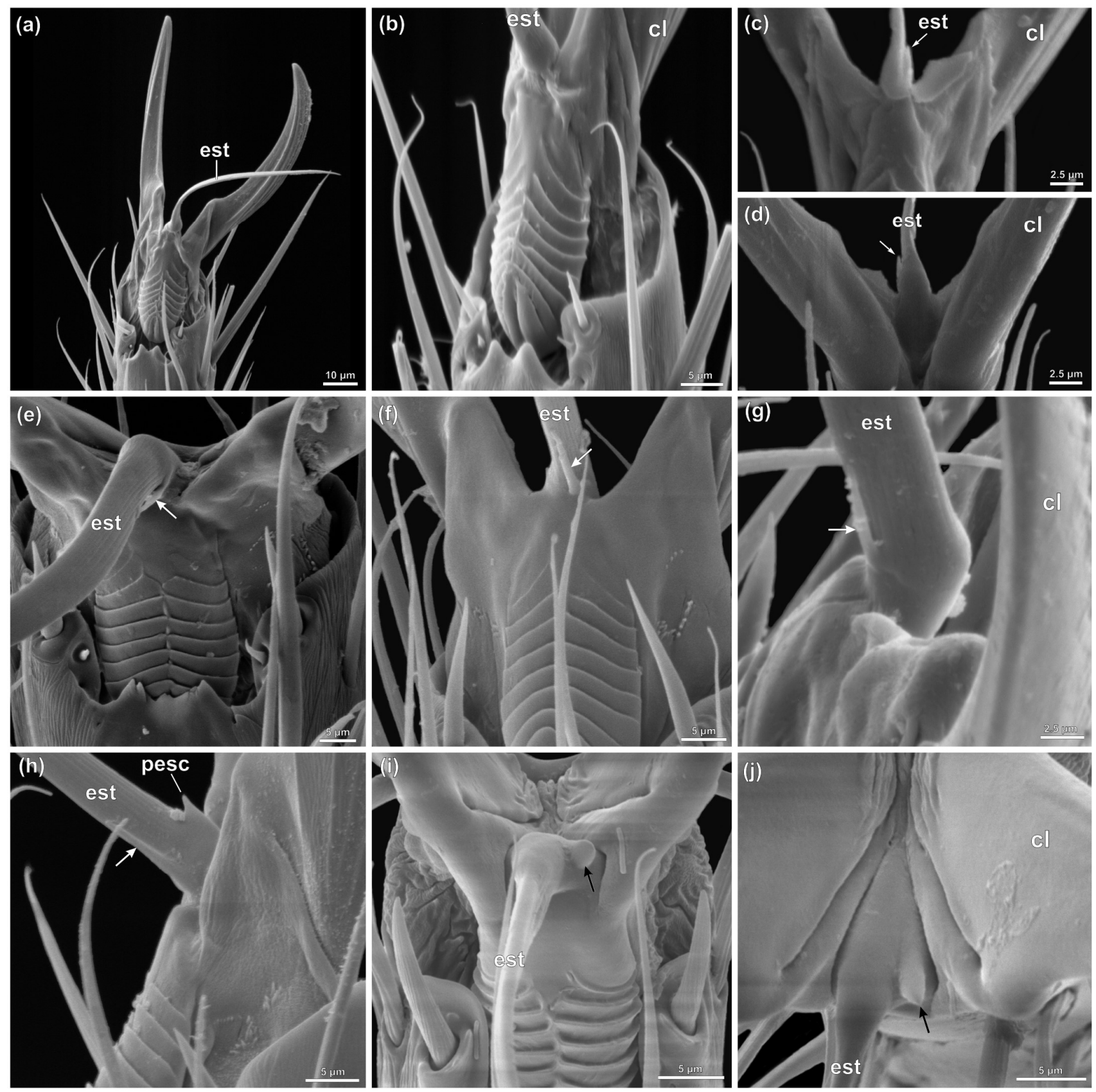

Fig. 22 
CAPÍTULO 3
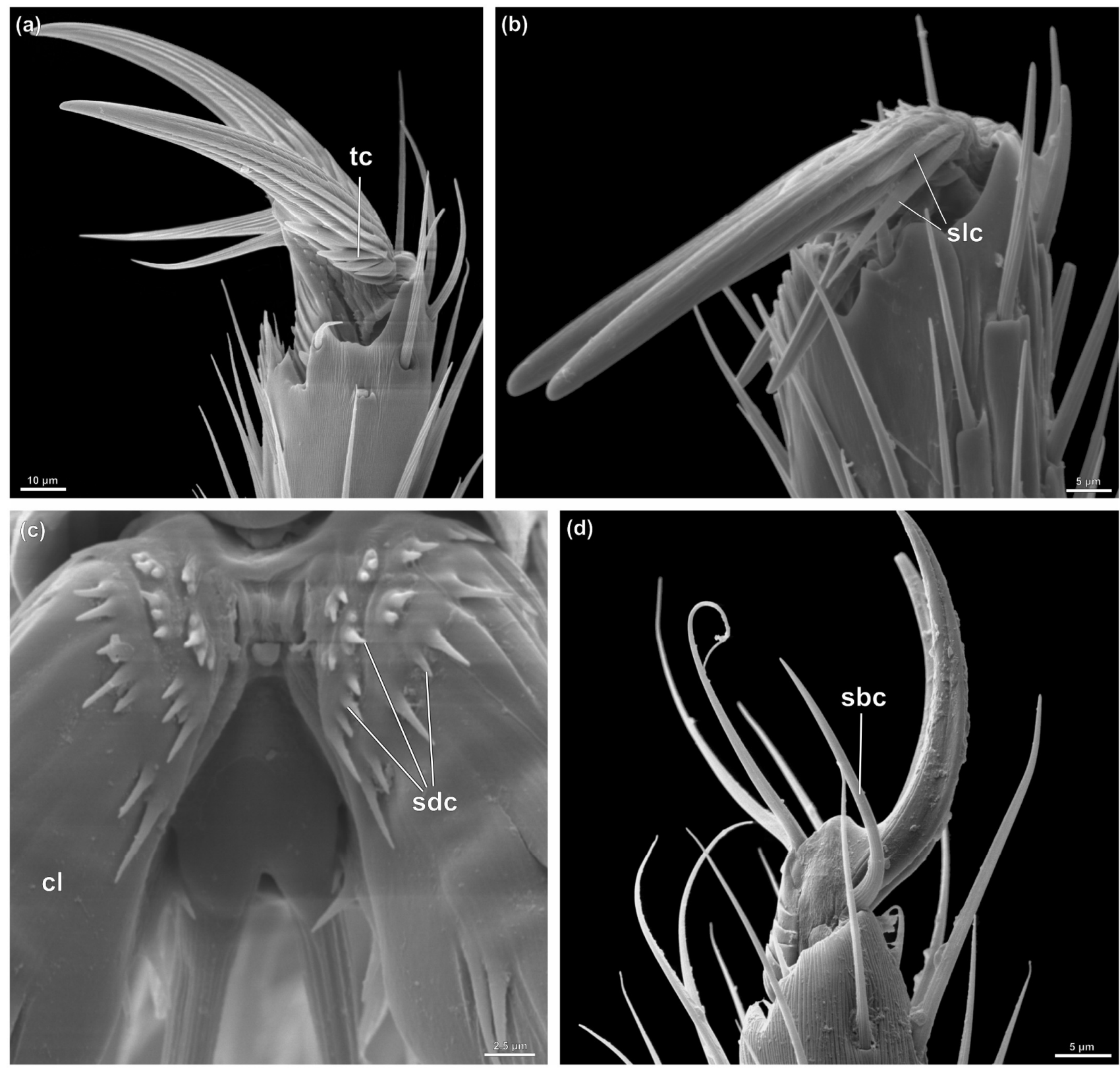

Fig. 23 

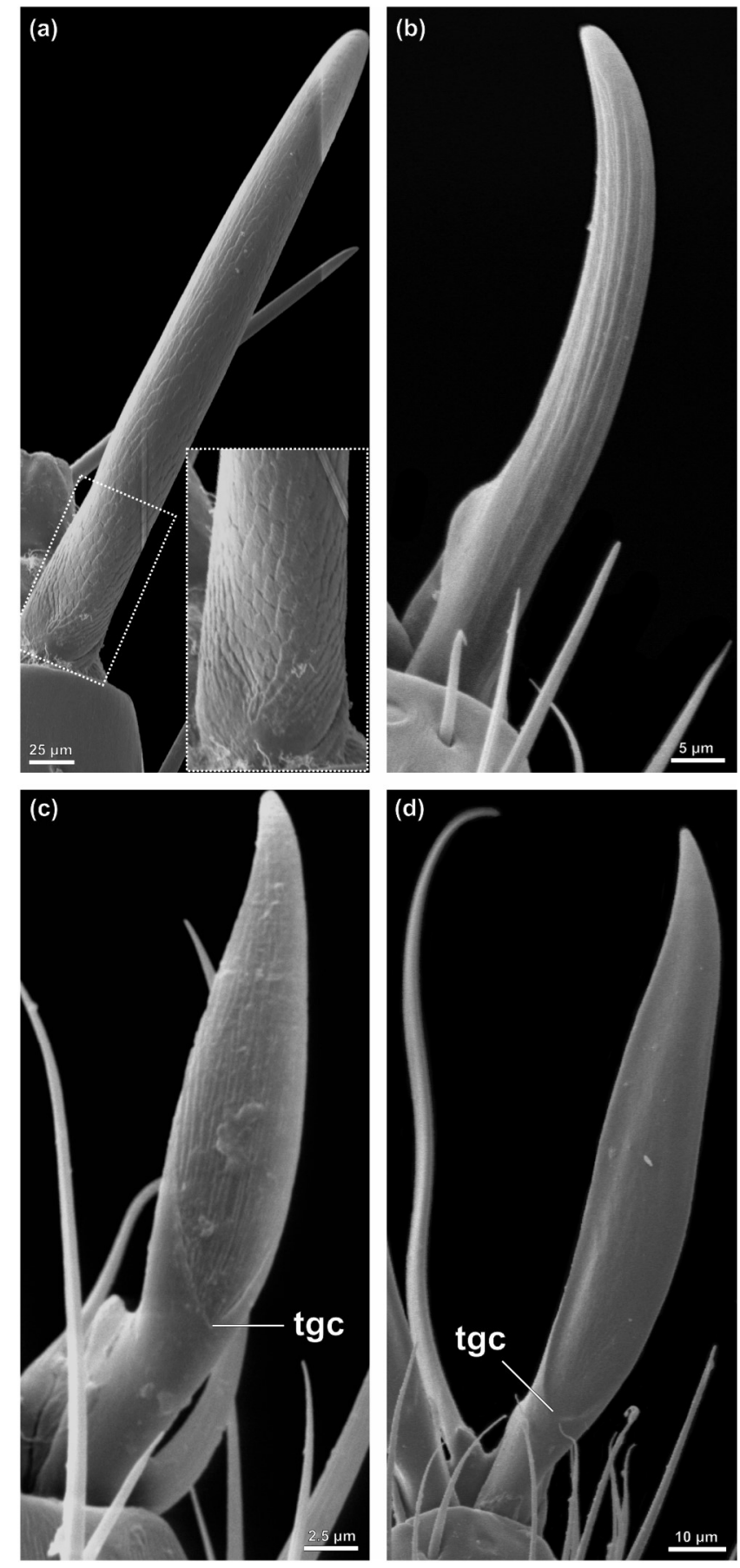

(d)

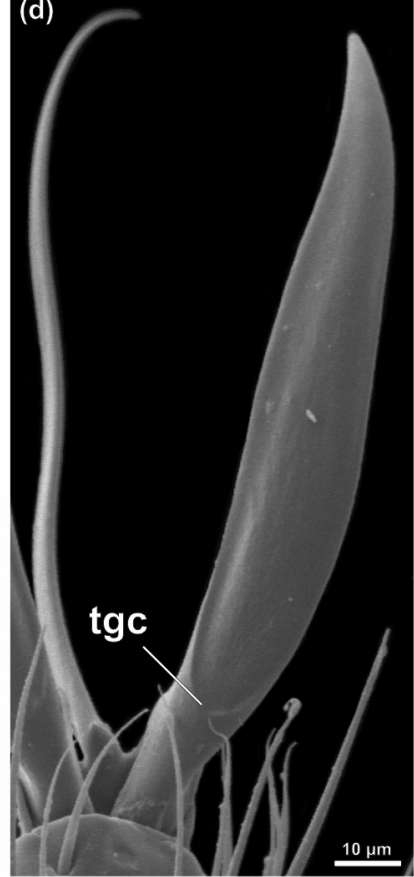

Fig. 24 


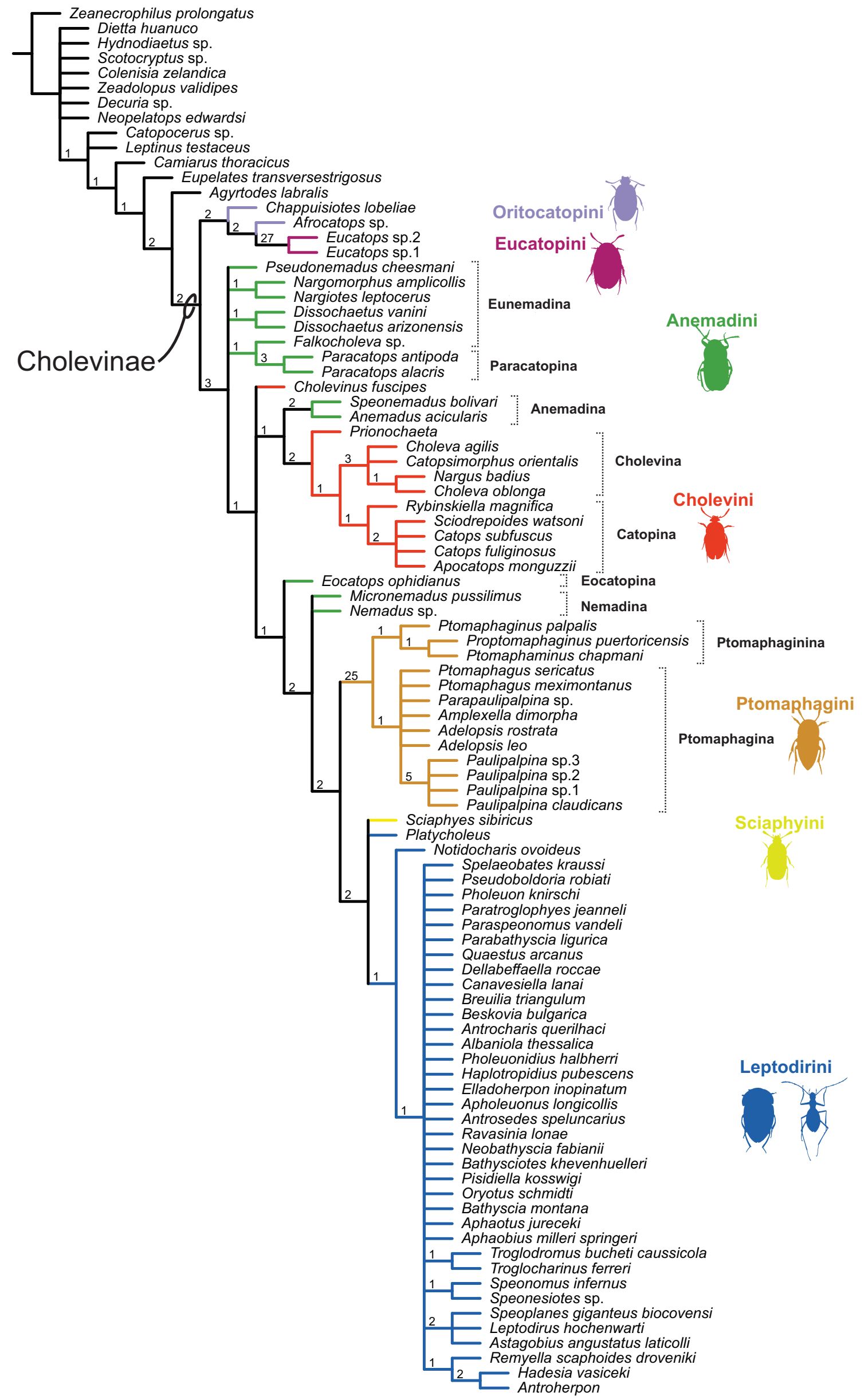

Fig. 25 


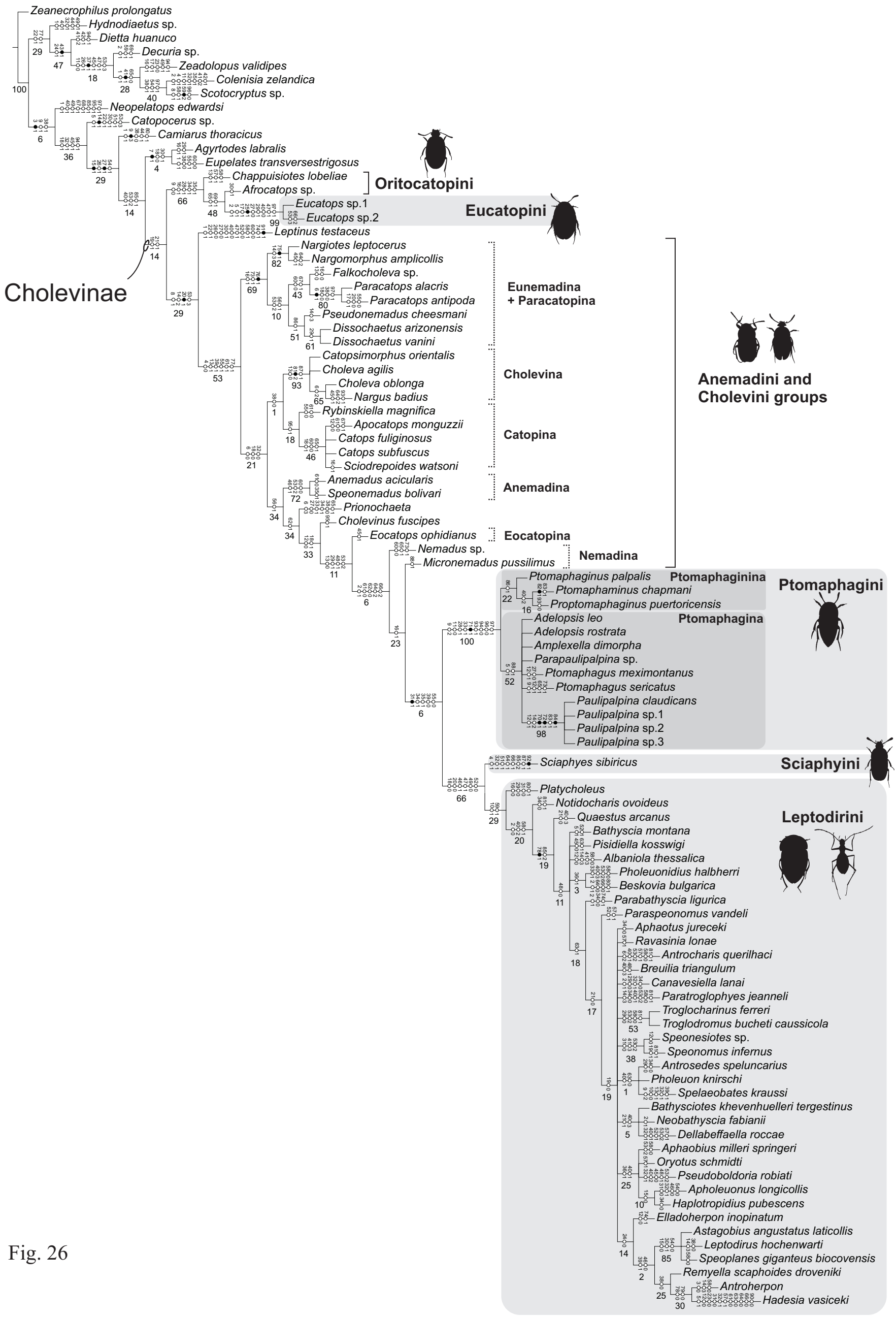




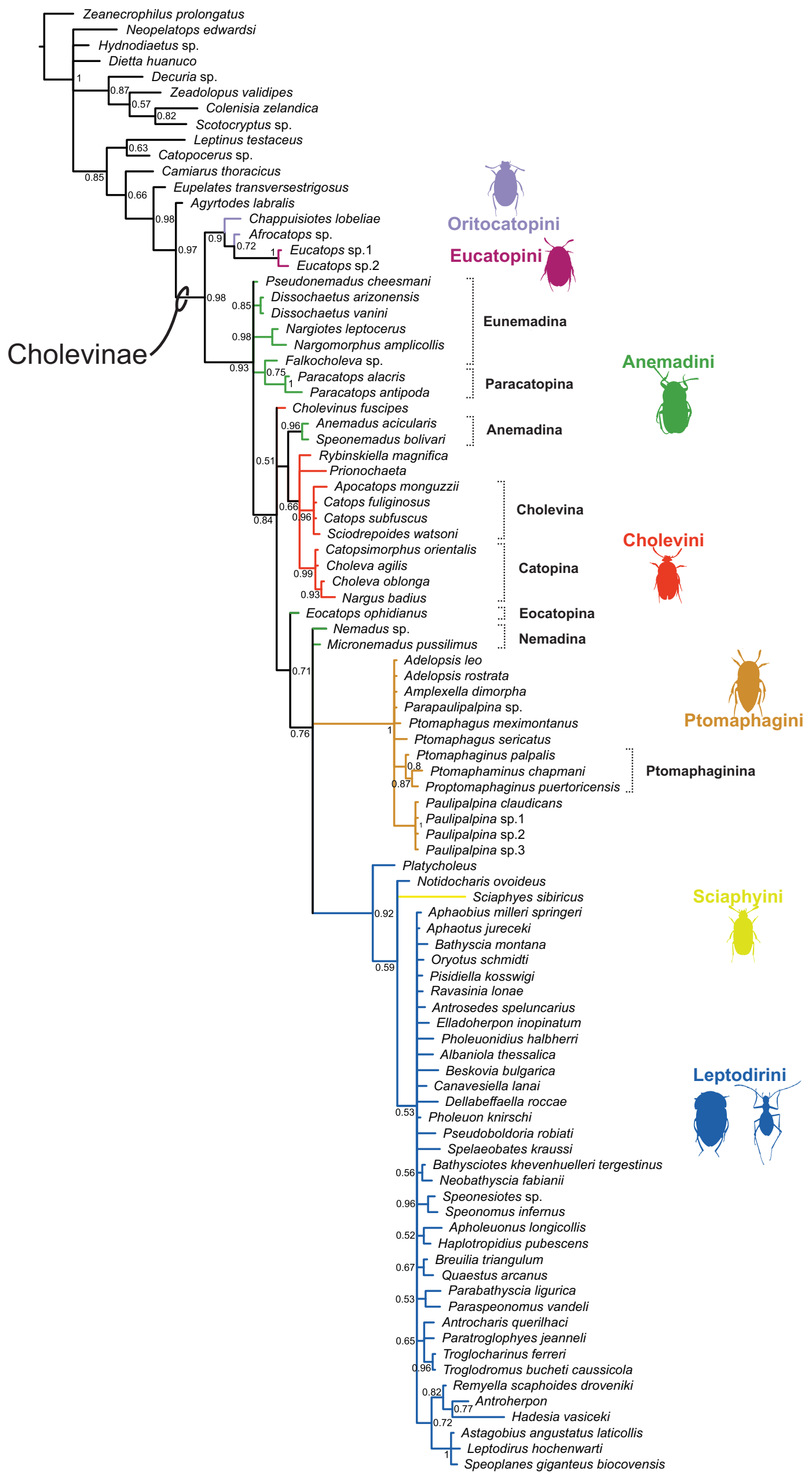

Fig. 27 
Appendix 1. Character matrix. Unapplicable characters are indicated by "-"; missing data are indicated by "?".

\begin{tabular}{|c|c|c|c|c|c|c|c|c|c|c|c|c|c|c|c|c|c|c|c|c|c|c|c|c|c|c|c|c|c|c|}
\hline Char & & & & & & & & & & 1 & & & & & & & & & & 2 & & & & & & & & & & \\
\hline Таха & 1 & 2 & 3 & 4 & 5 & 6 & 7 & 8 & 9 & 0 & 1 & 2 & 3 & 4 & 5 & 6 & 7 & 8 & 9 & 0 & 1 & 2 & 3 & 4 & 5 & 6 & 7 & 8 & 9 & 0 \\
\hline Zeanecrophilus prolongatus & 0 & 0 & 0 & 0 & 0 & 0 & 0 & 0 & 0 & 0 & 0 & 0 & 0 & 0 & 0 & 0 & 0 & 0 & 0 & 0 & 0 & 0 & 0 & 0 & 0 & 0 & 0 & 0 & - & 0 \\
\hline Anemadus acicularis & 0 & 0 & 1 & 0 & 0 & 0 & 0 & 1 & 1 & 0 & 1 & 1 & 1 & 2 & 1 & 0 & 0 & 0 & 1 & 1 & 1 & 0 & 1 & 1 & 0 & 1 & 1 & 0 & 0 & 0 \\
\hline Speonemadus bolivari & 0 & 0 & 1 & 0 & 0 & 0 & 0 & 1 & 1 & 0 & 1 & 1 & 1 & 2 & 1 & 0 & 0 & 0 & 1 & 1 & 1 & 0 & 1 & 1 & 0 & 1 & 1 & 0 & 0 & 0 \\
\hline Eocatops ophidianus & 0 & 0 & 1 & 0 & 0 & 0 & 0 & 1 & 1 & 0 & 1 & 0 & 0 & 2 & 1 & 0 & 0 & 1 & 1 & 1 & 1 & 0 & 1 & 1 & 0 & 1 & 1 & 0 & 1 & 0 \\
\hline Dissochaetus arizonensis & 0 & 0 & 1 & 0 & 0 & 3 & 0 & 1 & 1 & 0 & 1 & 0 & 1 & 2 & 1 & 1 & 0 & 1 & 1 & 1 & 1 & 0 & 1 & 1 & 0 & 1 & 1 & 0 & 1 & 0 \\
\hline Dissochaetus vanini & 0 & 0 & 1 & 0 & 0 & 3 & 0 & 1 & 1 & 0 & 1 & 0 & 1 & 2 & 1 & 1 & 0 & 1 & 1 & 1 & 1 & 0 & 1 & 1 & 0 & 1 & 1 & 0 & 1 & 0 \\
\hline Falkocholeva sp. & 0 & 0 & 1 & 0 & 0 & 3 & 0 & 1 & 1 & 0 & 1 & 0 & 0 & 2 & 1 & 0 & 0 & 1 & 1 & 1 & 1 & 0 & 1 & 1 & 0 & 1 & 1 & 0 & ? & 0 \\
\hline Nargiotes leptocerus & 0 & 0 & 1 & 0 & 0 & ? & 0 & 1 & 1 & ? & 1 & ? & 1 & 3 & 1 & 1 & 0 & 1 & 1 & 1 & 1 & 0 & 1 & 1 & 0 & 1 & 1 & 0 & 0 & 0 \\
\hline Nargomorphus amplicollis & 0 & 0 & 1 & 0 & 0 & 3 & 0 & 1 & 1 & 1 & 1 & 1 & 1 & 3 & 1 & 1 & 0 & 1 & 1 & 1 & 1 & 0 & 1 & 1 & 0 & 1 & 1 & 0 & 0 & 0 \\
\hline Pseudonemadus cheesmani & 0 & 0 & 1 & 0 & 0 & 3 & 0 & 1 & 1 & 0 & 1 & 0 & 1 & 3 & 1 & 1 & 0 & 1 & 1 & 1 & 1 & 0 & 1 & 1 & 0 & 1 & 1 & 0 & 0 & 0 \\
\hline Nemadus sp. & 0 & 1 & 1 & 0 & 0 & 0 & 0 & 1 & 1 & 0 & 1 & 0 & 0 & 2 & 1 & 0 & 0 & 1 & 1 & 1 & 1 & 0 & 1 & 1 & 0 & 1 & 1 & 0 & 1 & 0 \\
\hline Micronemadus pussilimus & 0 & $?$ & 1 & 0 & 0 & $?$ & 0 & 1 & 1 & ? & 1 & $?$ & 0 & 2 & 1 & 1 & 0 & 1 & 1 & 1 & 1 & 0 & 1 & 1 & 0 & 1 & 1 & 0 & 1 & 0 \\
\hline Paracatops alacris & 0 & 0 & 1 & 0 & 0 & 1 & 0 & 1 & 1 & 0 & 1 & 0 & 1 & 2 & 1 & 1 & 0 & 0 & 1 & 1 & 1 & 0 & 1 & 1 & 0 & 1 & 1 & 0 & 0 & 0 \\
\hline Paracatops antipoda & 0 & 0 & 1 & 0 & 0 & 1 & 0 & 1 & 1 & 0 & 1 & 0 & 1 & 2 & 1 & 1 & 1 & 0 & 1 & 0 & 1 & 0 & 1 & 1 & 0 & 1 & 1 & 0 & 0 & 0 \\
\hline Apocatops monguzzii & 0 & 0 & 1 & 0 & 0 & 0 & 0 & 1 & 1 & 0 & 1 & 0 & 1 & 2 & 1 & 0 & 0 & 1 & 1 & 1 & 1 & 0 & 1 & 1 & 0 & 1 & 1 & 0 & 0 & 0 \\
\hline Catops fuliginosus & 0 & 0 & 1 & 0 & 0 & 0 & 0 & 1 & 1 & 0 & 1 & 1 & 1 & 2 & 1 & 0 & 0 & 1 & 1 & 1 & 1 & 0 & 1 & 1 & 0 & 1 & 1 & 0 & 0 & 0 \\
\hline Catops subfuscus & 0 & 0 & 1 & 0 & 0 & 0 & 0 & 1 & 1 & 0 & 1 & 1 & 1 & 2 & 1 & 0 & 0 & 1 & 1 & 1 & 1 & 0 & 1 & 1 & 0 & 1 & 1 & 0 & 0 & 0 \\
\hline Cholevinus fuscipes & 0 & 0 & 1 & 0 & 0 & 0 & 0 & 1 & 1 & 0 & 1 & 0 & 1 & 2 & 1 & 0 & 0 & 1 & 1 & 1 & 1 & 0 & 1 & 1 & 0 & 1 & 1 & 0 & 0 & 0 \\
\hline Sciodrepoides watsoni & 0 & 0 & 1 & 0 & 0 & 0 & 0 & 1 & 1 & 0 & 1 & 1 & 1 & 2 & 1 & 1 & 0 & 1 & 1 & 1 & 1 & 0 & 1 & 1 & 0 & 1 & 1 & 0 & 0 & 0 \\
\hline Rybinskiella magnifica & 0 & 0 & 1 & 0 & 0 & 0 & 0 & 1 & 1 & 0 & 1 & 1 & 1 & 2 & 1 & 0 & 0 & 0 & 1 & 1 & 1 & 0 & 1 & 1 & 0 & 1 & 1 & 0 & 0 & 0 \\
\hline Catopsimorphus orientalis & 0 & 0 & 1 & 0 & 0 & 0 & 0 & 1 & 1 & 0 & 1 & 1 & 0 & 2 & 1 & 0 & 0 & 0 & 1 & 1 & 1 & 0 & 1 & 1 & 0 & 1 & 1 & 0 & 0 & 0 \\
\hline Choleva agilis & 0 & 0 & 1 & 0 & 0 & 0 & 0 & 1 & 1 & 0 & 1 & 1 & 0 & 2 & 1 & 0 & 0 & 0 & 1 & 1 & 1 & 0 & 1 & 1 & 0 & 1 & 1 & 0 & 0 & 0 \\
\hline Choleva oblonga & 0 & 0 & 1 & 0 & 0 & 2 & 0 & 1 & 1 & 0 & 1 & 1 & 0 & 2 & 1 & 0 & 0 & 0 & 1 & 1 & 1 & 0 & 1 & 1 & 0 & 1 & 1 & 0 & 0 & 0 \\
\hline Nargus badius & 0 & 0 & 1 & 0 & 0 & 2 & 0 & 1 & 1 & 0 & 1 & 1 & 0 & 2 & 1 & 0 & 0 & 0 & 1 & 1 & 1 & 0 & 1 & 1 & 0 & 1 & 1 & 0 & 0 & 0 \\
\hline Prionochaeta & 0 & 0 & 1 & 0 & 0 & 3 & 0 & 1 & 1 & 0 & 1 & 1 & 1 & 2 & 1 & 0 & 0 & 0 & 1 & 1 & 1 & 0 & 1 & 1 & 0 & 1 & 0 & 0 & 0 & 0 \\
\hline Eucatops sp.1 & 0 & 1 & 1 & 1 & 1 & 3 & 0 & 0 & 0 & 0 & 1 & 0 & 0 & 3 & 1 & 1 & 1 & 1 & 1 & 0 & 1 & 0 & 1 & 1 & 1 & 1 & 0 & 1 & 1 & 0 \\
\hline Eucatops sp. 2 & 0 & 1 & 1 & 1 & 1 & $?$ & 0 & 0 & 0 & 0 & 1 & 0 & 0 & 3 & 1 & 1 & 1 & 1 & 1 & 0 & 1 & 0 & 1 & 1 & 1 & 1 & 0 & 1 & 1 & 0 \\
\hline Antroherpon & 0 & 0 & 0 & 0 & 0 & 0 & 0 & 1 & 1 & 1 & 1 & 1 & 0 & 3 & 1 & 1 & 0 & 0 & 0 & 0 & 0 & 0 & 1 & 0 & 0 & 1 & 1 & 0 & 0 & 0 \\
\hline Hadesia vasiceki & 0 & 0 & 1 & 0 & 1 & 0 & 0 & 1 & 1 & 1 & 1 & 0 & 0 & 2 & 1 & 1 & 0 & 0 & 0 & 0 & 0 & 0 & 0 & 0 & 0 & 1 & 1 & 0 & $?$ & 0 \\
\hline Remyella scaphoides droveniki & 0 & 0 & 1 & 0 & 0 & 0 & 0 & 1 & 1 & 1 & 1 & 1 & 0 & 2 & 1 & 1 & 0 & 0 & 0 & 0 & 0 & 0 & 1 & 0 & 0 & 1 & 1 & 0 & 0 & 0 \\
\hline Aphaobius milleri springeri & 0 & 0 & 1 & 0 & 0 & 0 & 0 & 1 & 1 & 1 & 1 & 1 & 0 & 2 & 1 & 1 & 0 & 0 & 0 & 0 & 0 & 0 & 1 & 1 & 0 & 1 & 1 & 0 & 1 & 0 \\
\hline Aphaotus jureceki & 0 & 0 & 1 & 0 & 0 & 0 & 0 & 1 & 1 & 1 & 1 & 1 & 0 & 2 & 1 & 1 & 0 & 0 & 0 & 0 & 0 & 0 & 1 & 1 & 0 & 1 & 1 & 0 & ? & 0 \\
\hline Bathyscia montana & 0 & 0 & 1 & 0 & 1 & 0 & 0 & 1 & 1 & 1 & 1 & 1 & 0 & 2 & 1 & 1 & 0 & 0 & 1 & 0 & 1 & 0 & 1 & 1 & 0 & 1 & 1 & 0 & 1 & 0 \\
\hline Oryotus schmidti & 0 & 0 & 1 & 0 & 0 & 0 & 0 & 1 & 1 & 1 & 1 & $?$ & 0 & 2 & 1 & 1 & 0 & 0 & 0 & 0 & 0 & 0 & 1 & 1 & 0 & 1 & 1 & 0 & 1 & 0 \\
\hline Pisidiella kosswigi & 0 & 0 & 1 & 0 & 0 & 0 & 0 & 1 & 1 & 1 & 1 & 1 & 0 & 2 & 1 & 1 & 0 & 0 & 1 & 0 & 1 & 0 & 1 & 1 & 0 & 1 & 1 & 0 & 1 & 0 \\
\hline Bathysciotes khevenhuelleri & 0 & 0 & 1 & 0 & 0 & 0 & 0 & 1 & 1 & 1 & 1 & 1 & 0 & 2 & 1 & 1 & 0 & 0 & 0 & 0 & 1 & 0 & 1 & 1 & 0 & 1 & 1 & 0 & 1 & 0 \\
\hline Neobathyscia fabianii & 0 & 1 & 1 & 0 & 0 & ? & 0 & 1 & 1 & 1 & 1 & $?$ & 0 & 2 & 1 & 1 & 0 & 0 & 0 & 0 & 1 & 0 & 1 & 1 & 0 & 1 & 1 & 0 & 1 & 0 \\
\hline Ravasinia lonae & 0 & 0 & 1 & 0 & 0 & 0 & 0 & 1 & 1 & 1 & 1 & 1 & 0 & 2 & 1 & 1 & 0 & 0 & 0 & 0 & 0 & 0 & 1 & 1 & 0 & 1 & 1 & 0 & ? & 0 \\
\hline
\end{tabular}


Speonesiotes sp.

Antrosedes speluncarius

Apholeuonus longicollis

Astagobius angustatus laticollis

Elladoherpon inopinatum

Haplotropidius pubescens

Leptodirus hochenwarti

Pholeuonidius halbherri

Speoplanes giganteus biocovensis

Albaniola thessalica

Antrocharis querilhaci

Beskovia bulgarica

Breuilia triangulum

Canavesiella lanai

Dellabeffaella roccae

Quaestus arcanus

Notidocharis ovoideus

Parabathyscia ligurica

Paraspeonomus vandeli

Paratroglophyes jeanneli

Pholeuon knirschi

Pseudoboldoria robiati

Troglocharinus ferreri

Troglodromus bucheti caussicola

Platycholeus

Spelaeobates kraussi

Afrocatops sp.

Chappuisiotes lobeliae

Adelopsis leo

Adelopsis rostrata

Amplexella dimorpha

Paulipalpina claudicans

Paulipalpina sp.1

Paulipalpina sp.2

Paulipalpina sp.3

Parapaulipalpina sp.

Ptomaphagus meximontanus

Ptomaphagus sericatus

Ptomaphaginus palpalis

Ptomaphaminus chapmani

Proptomaphaginus puertoricensis

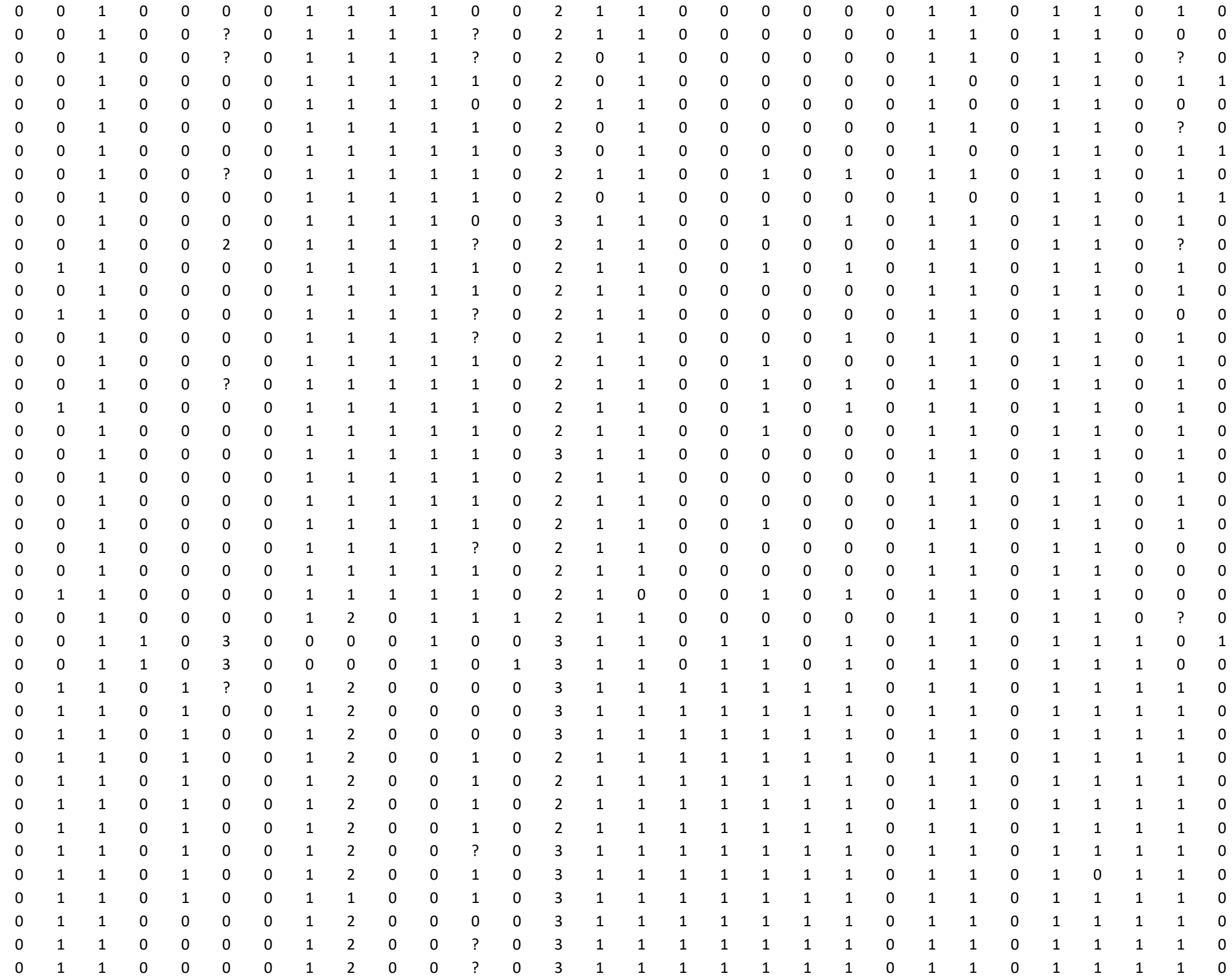


Baryodirus hammondi

Sciaphyes sibiricus

Agyrtodes labralis

Eupelates transversestrigosus

Camiarus thoracicus

Neopelatops edwardsi

Decuria sp.

Zeadolopus validipes

Colenisia zelandica

Scotocryptus sp.

Hydnodiaetus sp.

Dietta huanuco

Leptinus testaceus

Catopocerus sp.

$\begin{array}{lllllllllllllllllllllllllllllllllll}? & ? & ? & 0 & 1 & 0 & 0 & 1 & 2 & 0 & 0 & ? & ? & ? & 1 & ? & ? & ? & 1 & 1 & 1 & 0 & 1 & ? & ? & ? & ? & ? & ? & 0 \\ 0 & 1 & 1 & 1 & ? & ? & 0 & 1 & 1 & 0 & 1 & ? & 0 & 3 & 1 & 1 & 1 & 0 & 1 & 0 & 1 & 0 & 1 & 1 & 0 & 1 & 1 & 0 & 1 & 0 \\ 0 & 0 & 1 & 1 & 0 & 3 & 1 & 0 & 1 & 0 & 1 & 0 & 0 & 3 & 1 & 1 & 0 & 0 & 0 & 0 & 0 & 0 & 1 & 1 & 0 & 1 & 1 & 0 & 1 & 1 \\ 1 & 0 & 1 & 1 & 0 & 3 & 1 & 0 & 1 & 0 & 1 & 0 & 0 & 3 & 1 & 0 & 0 & 0 & 0 & 0 & 0 & 0 & 1 & 0 & 0 & 1 & 1 & 0 & 0 & 1 \\ 1 & 0 & 1 & 0 & 0 & 3 & 0 & 0 & 3 & 0 & 1 & 0 & 0 & 3 & 1 & 0 & 0 & 1 & 0 & 0 & 0 & 0 & 1 & 0 & 0 & 1 & 1 & 0 & 0 & 0 \\ 1 & 0 & 1 & 0 & 0 & 3 & 0 & 0 & 1 & 0 & 1 & 0 & 0 & 3 & 0 & 0 & 0 & 0 & 0 & 0 & 0 & 0 & 1 & 0 & 0 & 0 & 0 & 0 & - & 0 \\ 0 & 1 & 0 & 0 & 0 & 3 & 0 & 0 & 1 & 0 & 0 & 0 & 0 & 3 & 0 & 0 & 0 & 0 & 0 & 0 & 0 & 1 & 1 & 1 & 0 & 1 & 0 & 0 & ? & 1 \\ 1 & 0 & 0 & 0 & 0 & 3 & 0 & 0 & 1 & 0 & 0 & 0 & 0 & 3 & 0 & 1 & 1 & 1 & 0 & 0 & 0 & 1 & 0 & 1 & 0 & 1 & 0 & 0 & 1 & 0 \\ 1 & 1 & 0 & 1 & 0 & 3 & 0 & 0 & 0 & 0 & 1 & 0 & 0 & 1 & 0 & 0 & 0 & 1 & 0 & 0 & 0 & 1 & 1 & 1 & 0 & 1 & 0 & 0 & 0 & 1 \\ 1 & 0 & 0 & 0 & 0 & 3 & 0 & 1 & 0 & 0 & 0 & 0 & 0 & 2 & 0 & 0 & 0 & 0 & 0 & 0 & 0 & 1 & 1 & 1 & 0 & 1 & 0 & 0 & 1 & 1 \\ 1 & 0 & 0 & 1 & 0 & 3 & 0 & 0 & 0 & 0 & 1 & 0 & 0 & 3 & 0 & 0 & 0 & 0 & 0 & 0 & 0 & 1 & 1 & 0 & 0 & 0 & 0 & 0 & - & 0 \\ 0 & 0 & 0 & 0 & 0 & 3 & 0 & 0 & 0 & 0 & 1 & 0 & 0 & 3 & 0 & 0 & 0 & 0 & 0 & 0 & 0 & 1 & 1 & 1 & 0 & 0 & 0 & 0 & - & 0 \\ 1 & 0 & 1 & 1 & 0 & 3 & 0 & 1 & 1 & 0 & 1 & 0 & 0 & 2 & 1 & 0 & 0 & 1 & 1 & 1 & 1 & 1 & 1 & 0 & 0 & 0 & 0 & 0 & - & 1 \\ 0 & 0 & 1 & 1 & 1 & 3 & 0 & 0 & 1 & 0 & 1 & 0 & 0 & 1 & 0 & 0 & 0 & 1 & 0 & 0 & 0 & 1 & 1 & 0 & 0 & 0 & 0 & 0 & - & 1\end{array}$

\section{(Continued)}

\begin{tabular}{|c|c|c|c|c|c|c|c|c|c|c|c|c|c|c|c|c|c|c|c|c|c|c|c|c|c|c|c|c|c|c|}
\hline Characters & 3 & & & & & & & & & 4 & & & & & & & & & & 5 & & & & & & & & & & \\
\hline Taxa & 1 & 2 & 3 & 4 & 5 & 6 & 7 & 8 & 9 & 0 & 1 & 2 & 3 & 4 & 5 & 6 & 7 & 8 & 9 & 0 & 1 & 2 & 3 & 4 & 5 & 6 & 7 & 8 & 9 & 0 \\
\hline Zeanecrophilus prolongatus & 0 & 0 & 0 & 0 & 0 & 0 & 0 & 0 & 0 & 0 & 0 & 0 & 0 & 0 & 0 & 0 & 0 & 0 & 0 & 0 & 0 & 0 & 0 & 0 & 0 & - & 0 & 0 & 0 & 0 \\
\hline Anemadus acicularis & 0 & 0 & 0 & 0 & 0 & 0 & 0 & 1 & 1 & - & - & 0 & 0 & 0 & 0 & 1 & 0 & 0 & 1 & 0 & 0 & 1 & 2 & 1 & 1 & 1 & 0 & 0 & 0 & 0 \\
\hline Speonemadus bolivari & 0 & 0 & 0 & 0 & 1 & 0 & 0 & 1 & 1 & - & - & 0 & 0 & 0 & 0 & 1 & 0 & 0 & 1 & 0 & 0 & 1 & 2 & 1 & 1 & 1 & 0 & 0 & 0 & 0 \\
\hline Eocatops ophidianus & 0 & 0 & 0 & 0 & 0 & 0 & 0 & 1 & 1 & - & - & 0 & 0 & 0 & 1 & 0 & 0 & 1 & 1 & 0 & 0 & 1 & 2 & 1 & 1 & 1 & 0 & 0 & 0 & 1 \\
\hline Dissochaetus arizonensis & 0 & 1 & - & 0 & 0 & 0 & 0 & 1 & 1 & - & - & 0 & 0 & 0 & 0 & 0 & 0 & 0 & 1 & 0 & 0 & 1 & 2 & 1 & 1 & 1 & 0 & 0 & 0 & 1 \\
\hline Dissochaetus vanini & 0 & 1 & - & 0 & 0 & 0 & 0 & 1 & 1 & - & - & 0 & 0 & 0 & 0 & 0 & 0 & 0 & 1 & 0 & 0 & 1 & 2 & 1 & 1 & 1 & 0 & 0 & 0 & 1 \\
\hline Falkocholeva sp. & 0 & 1 & - & 0 & 0 & 0 & 0 & 1 & 1 & - & - & 0 & 0 & 0 & 0 & 0 & 0 & 0 & 1 & 0 & 0 & 1 & 2 & 1 & 1 & 1 & 0 & 0 & 0 & 0 \\
\hline Nargiotes leptocerus & 0 & 1 & - & 0 & 0 & 0 & 0 & 1 & 1 & - & - & 0 & 0 & 0 & 0 & 0 & 0 & 0 & 1 & 0 & 0 & 1 & 3 & 1 & 1 & 0 & 0 & 0 & 0 & 1 \\
\hline Nargomorphus amplicollis & 0 & 1 & - & 0 & 0 & 0 & 0 & 1 & 1 & - & - & 0 & 0 & 0 & 1 & 0 & 0 & 0 & 1 & 0 & 0 & 1 & 3 & 1 & 1 & 0 & 0 & 0 & 0 & 1 \\
\hline Pseudonemadus cheesmani & 0 & 1 & - & 0 & 0 & 0 & 0 & 1 & 1 & - & - & 0 & 0 & 0 & 0 & 0 & 0 & 0 & 1 & 0 & 0 & 1 & 2 & 1 & 1 & 1 & 0 & 0 & 0 & 1 \\
\hline Nemadus sp. & 0 & 0 & 0 & 0 & 0 & 0 & 0 & 1 & 1 & - & - & 0 & 0 & 0 & 0 & 0 & 0 & 1 & 1 & 0 & 0 & 1 & 2 & 1 & 1 & 1 & 0 & 1 & 0 & 0 \\
\hline Micronemadus pussilimus & 0 & 0 & 0 & 0 & 0 & 0 & 0 & 1 & 1 & - & - & 0 & 0 & 0 & 0 & 0 & 0 & 1 & 1 & 0 & 0 & 1 & 2 & 1 & 1 & 1 & 0 & 1 & 0 & 1 \\
\hline Paracatops alacris & 0 & 1 & - & 0 & 0 & 0 & 0 & 0 & 1 & - & - & 0 & 0 & 0 & 0 & 0 & 0 & 0 & 1 & 0 & 0 & 1 & 2 & 1 & 1 & 1 & 0 & 0 & 0 & 0 \\
\hline Paracatops antipoda & 0 & 1 & - & 0 & 0 & 0 & 0 & 0 & 1 & - & - & 0 & 0 & 0 & 0 & 0 & 0 & 0 & 1 & 0 & 0 & 1 & 2 & 1 & 0 & - & 0 & 0 & 0 & 0 \\
\hline Apocatops monguzzii & 0 & 0 & 0 & 0 & 0 & 0 & 0 & 0 & 1 & - & - & 0 & 0 & 0 & 0 & 0 & 0 & 0 & 1 & 0 & 0 & 1 & 3 & 1 & 1 & 0 & 0 & 0 & 0 & 0 \\
\hline Catops fuliginosus & 0 & 0 & 0 & 0 & 0 & 0 & 0 & 0 & 1 & - & - & 0 & 0 & 0 & 0 & 0 & 0 & 0 & 1 & 0 & 0 & 1 & 3 & 1 & 1 & 0 & 0 & 0 & 0 & 0 \\
\hline Catops subfuscus & 0 & 0 & 0 & 0 & 0 & 0 & 0 & 0 & 1 & - & - & 0 & 0 & 0 & 0 & 0 & 0 & 0 & 1 & 0 & 0 & 1 & 3 & 1 & 1 & 0 & 0 & 0 & 0 & 0 \\
\hline Cholevinus fuscipes & 0 & 0 & 0 & 0 & 0 & 0 & 0 & 1 & 1 & - & - & 0 & 0 & 0 & 0 & 0 & 0 & 0 & 1 & 0 & 0 & 1 & 3 & 1 & 1 & 1 & 0 & 0 & 0 & 1 \\
\hline Sciodrepoides watsoni & 0 & 0 & 0 & 0 & 0 & 0 & 0 & 0 & 1 & - & - & 0 & 0 & 0 & 0 & 0 & 0 & 0 & 1 & 0 & 0 & 1 & 3 & 1 & 1 & 0 & 0 & 0 & 0 & 0 \\
\hline Rybinskiella magnifica & 0 & 0 & 0 & 0 & 0 & 0 & 0 & 0 & 1 & - & - & 0 & 0 & 0 & 0 & 0 & 0 & 0 & 1 & 0 & 0 & 1 & 3 & 1 & 0 & - & 0 & 0 & 0 & 1 \\
\hline Catopsimorphus orientalis & 0 & 0 & 0 & 0 & 0 & 0 & 0 & 0 & 1 & - & - & 0 & 0 & 0 & 0 & 0 & 0 & 0 & 1 & 0 & 0 & 1 & 3 & 1 & 1 & 0 & 0 & 0 & 0 & 1 \\
\hline Choleva agilis & 0 & 0 & 0 & 0 & 0 & 0 & 0 & 0 & 1 & - & - & 0 & 0 & 0 & 0 & 0 & 0 & 0 & 1 & 0 & 0 & 1 & 3 & 1 & 1 & 0 & 0 & 0 & 0 & 1 \\
\hline
\end{tabular}


Eucatops sp. 2

Antroherpon

Hadesia vasiceki

Remyella scaphoides droveniki

Aphaobius milleri springeri

Aphaotus jurecek

Bathyscia montana

Oryotus schmidti

Pisidiella kosswigi

Bathysciotes khevenhuelleri

Neobathyscia fabianii

Ravasinia lonae

Speonesiotes sp.

Antrosedes speluncarius

Apholeuonus longicollis

Astagobius angustatus laticollis

Elladoherpon inopinatum

Haplotropidius pubescens

eptodirus hochenwart

Pholeuonidius halbherri

Speoplanes giganteus biocovensis

Albaniola thessalica

Antrocharis querilhac

Beskovia bulgarica

Breuilia triangulum

Canavesiella lanai

Dellabeffaella roccae

Quaestus arcanus

Notidocharis ovoideus

Parabathyscia ligurica

Paraspeonomus vandeli

Paratroglophyes jeanneli

Pholeuon knirschi

Pseudoboldoria robiati

Speonomus infernus

Troglocharinus ferreri

Troglodromus bucheti caussicola

Platycholeus

\begin{tabular}{|c|c|c|c|c|c|c|c|c|c|c|c|c|c|c|c|c|c|c|c|c|c|c|c|c|c|c|c|c|c|c|c|c|c|c|c|c|c|c|}
\hline 0 & 0 & & 0 & 0 & & & & & - & - & 0 & & 0 & 0 & 0 & 0 & 0 & 1 & 0 & & 1 & 3 & 1 & 1 & 0 & 0 & 0 & 0 & 0 & 0 & 0 & 0 & 1 & 0 & & & & 0 \\
\hline 0 & 0 & & 0 & 0 & & & & & - & - & 0 & & 0 & 1 & 0 & 0 & & 1 & & & 1 & 3 & 1 & 1 & 0 & 0 & 0 & 0 & 0 & 0 & 0 & 0 & 1 & 0 & 0 & 1 & 0 & 0 \\
\hline 0 & 0 & & 1 & 0 & & & & & - & - & 0 & & 0 & 0 & 0 & 0 & & 1 & & & 1 & 3 & 1 & 1 & 1 & 0 & 0 & 0 & 1 & 0 & 0 & 0 & 1 & 0 & 0 & 1 & 0 & 0 \\
\hline 0 & 1 & - & 1 & 1 & & & & & 0 & 0 & 0 & & 0 & 1 & 0 & 1 & & 1 & & & 1 & 2 & 1 & 0 & - & 0 & 0 & 0 & & 0 & 0 & 1 & 0 & 0 & 0 & 1 & 0 & 0 \\
\hline 0 & 1 & - & 1 & 1 & & & & & 0 & 0 & 0 & & 0 & 1 & 0 & 1 & & & & & 1 & 3 & 1 & 0 & - & 0 & $c$ & 0 & & 0 & 0 & 1 & 0 & 0 & 0 & 1 & 0 & 0 \\
\hline 1 & 0 & 0 & 1 & 1 & & & & 1 & - & - & 0 & & 0 & 1 & 0 & 1 & & & & & 0 & 3 & 1 & 0 & - & 0 & 0 & 1 & & 0 & 0 & 0 & 1 & 0 & 0 & 0 & 0 & 0 \\
\hline 0 & 1 & - & 1 & 1 & & & & & - & - & 0 & & 0 & 1 & 0 & 1 & & 0 & & & 0 & 3 & 1 & 0 & - & 1 & 1 & 1 & & 0 & 0 & 0 & 1 & 0 & 0 & 0 & 0 & 0 \\
\hline 1 & 0 & 0 & 1 & 1 & & & & & - & - & 0 & & 0 & 1 & 0 & 1 & & & & & 0 & 3 & 1 & 0 & - & 0 & 1 & 1 & & 0 & 0 & 0 & 1 & 0 & 0 & 0 & 0 & 0 \\
\hline 1 & 0 & 0 & 1 & 1 & & & & & 1 & 0 & 0 & 0 & 0 & 1 & 1 & 1 & & & & & 0 & 2 & 1 & 0 & - & 0 & 0 & 1 & & 1 & 0 & 1 & 0 & 0 & 0 & 0 & 0 & 0 \\
\hline 1 & 0 & 0 & 0 & 1 & & & & & 2 & 0 & 0 & & 0 & 1 & 1 & 1 & & & & & 0 & 3 & 1 & 0 & - & 0 & 1 & 1 & & 0 & 0 & 1 & 0 & 0 & 0 & 0 & 0 & 0 \\
\hline 1 & 0 & 0 & 1 & 1 & & & & 0 & 2 & 0 & 0 & & 0 & 1 & 1 & 1 & & & & & 1 & 3 & 1 & 0 & - & 0 & 1 & 1 & & 0 & 0 & 1 & 0 & 0 & 0 & 0 & 0 & 0 \\
\hline 1 & 0 & 0 & 1 & 1 & & & & & 1 & 0 & 0 & & 0 & 1 & 1 & 1 & & & & & 0 & 3 & 1 & 0 & - & 1 & 1 & 1 & & 1 & 0 & 1 & 0 & 0 & 0 & 0 & 0 & 0 \\
\hline 1 & 0 & 0 & 1 & 1 & & & & 0 & 2 & 0 & 0 & & 0 & 0 & 1 & 1 & & 0 & & & 0 & 3 & 1 & 0 & - & 0 & 1 & 1 & & 0 & 0 & 1 & & 0 & 0 & & 0 & 0 \\
\hline 1 & 0 & 0 & 1 & 1 & & & & 0 & 3 & 0 & 0 & & 0 & 1 & 1 & 1 & & 0 & & & 0 & 3 & 1 & 0 & - & 0 & 1 & 1 & & 0 & 0 & 1 & & 0 & 0 & & 0 & 0 \\
\hline 1 & 0 & 0 & 0 & 1 & & & & 0 & 3 & 0 & 0 & & 0 & 1 & 1 & 1 & & & & & 0 & 3 & 1 & 0 & - & 0 & 1 & 1 & & 0 & 0 & 1 & & 0 & 0 & 0 & 0 & 0 \\
\hline 1 & 0 & 0 & 1 & 1 & & & & 0 & 2 & 0 & 0 & 0 & 0 & 1 & 1 & 1 & & & & & 0 & 3 & 1 & 0 & - & 1 & 1 & 1 & & 0 & 0 & 1 & & 0 & 0 & 0 & 0 & 0 \\
\hline 0 & 0 & 0 & 1 & 1 & & & & 0 & - & 3 & 0 & & 0 & 1 & 1 & 1 & & & & & 0 & 2 & 1 & 0 & - & 0 & 1 & 1 & & 0 & 0 & 1 & & - & 0 & 0 & 0 & 0 \\
\hline 1 & 0 & 0 & 0 & 1 & & & & 0 & 1 & ? & 0 & & 0 & 1 & 1 & 1 & & & & & 0 & 3 & 1 & 0 & - & 0 & 1 & 1 & & 0 & 0 & 1 & & 0 & 0 & 0 & 0 & 0 \\
\hline 0 & 1 & - & 1 & 1 & & & & 0 & 1 & 0 & 0 & & 0 & 1 & 0 & 1 & & & & & 0 & 3 & 0 & 0 & - & 0 & 1 & 1 & & 1 & 0 & 1 & & 0 & 0 & 0 & 0 & 0 \\
\hline - & 0 & 0 & 0 & 1 & & & & 1 & - & - & 0 & & 0 & 1 & 0 & 1 & & & & & 0 & 3 & 0 & 0 & - & 0 & 1 & 1 & & 0 & 0 & 1 & & 0 & 0 & 0 & 0 & 0 \\
\hline 1 & 0 & 0 & 0 & 1 & & & 1 & 0 & 2 & 0 & 0 & & 0 & 1 & 1 & 1 & & 0 & & & 0 & 3 & 1 & 0 & - & 0 & 1 & 1 & & 0 & 0 & & & 0 & 0 & & 0 & 0 \\
\hline 1 & 0 & 0 & 0 & 1 & & & 1 & 0 & 1 & 0 & 0 & & 0 & 1 & 1 & 1 & & 0 & & & 0 & 3 & 1 & 0 & - & 0 & 1 & 1 & & 1 & 0 & & & 0 & 0 & & 0 & 0 \\
\hline- & 0 & 0 & 0 & 1 & & & 0 & 1 & - & - & 0 & & 0 & 1 & 0 & 1 & & 0 & & & 0 & 3 & 0 & 0 & - & 0 & 1 & 1 & & 0 & 0 & & & 0 & 0 & 0 & 0 & 0 \\
\hline 1 & 0 & 1 & 1 & 1 & & & 1 & 0 & 3 & 0 & 0 & & 0 & 1 & 1 & 1 & & & & & 0 & 2 & 1 & 0 & - & 0 & 0 & 1 & & 1 & 0 & & & 0 & 0 & 0 & 0 & 0 \\
\hline - & 0 & 0 & 0 & 1 & & & 1 & 1 & - & - & 0 & & 0 & 1 & 0 & 1 & & & & & 0 & 3 & 0 & 0 & - & 0 & 0 & 1 & & 0 & 0 & & & 0 & 0 & 0 & 0 & 0 \\
\hline 1 & 0 & 0 & 1 & 1 & & & 1 & 0 & - & 3 & 0 & & 0 & 1 & 1 & 1 & & & & & 0 & 3 & 1 & 0 & - & 0 & 0 & 1 & & 0 & 0 & & & - & 0 & 0 & 0 & 0 \\
\hline 1 & 0 & 0 & 1 & 1 & & & 1 & 0 & 1 & 0 & 0 & & 0 & 1 & 1 & 1 & & & & & 0 & 2 & 1 & 0 & - & 1 & $c$ & 1 & & 0 & 0 & & & 0 & 0 & 0 & 0 & 0 \\
\hline 1 & 0 & 0 & 1 & 1 & & & 1 & 0 & 2 & 0 & 0 & & 0 & 1 & 1 & 1 & & 0 & & & 0 & 3 & 1 & 0 & - & 0 & 1 & 1 & & 1 & 0 & & & 0 & 0 & & 0 & 0 \\
\hline 1 & 0 & 0 & 1 & 1 & & & 1 & 0 & 3 & 0 & 0 & & 0 & 1 & 1 & 1 & 1 & 0 & & & 0 & 3 & 1 & 0 & - & 0 & 1 & 1 & & 0 & 0 & & & 0 & 1 & & 0 & 0 \\
\hline 1 & 1 & - & 0 & 1 & & & 1 & 0 & 2 & 0 & 0 & & 0 & 1 & 1 & 1 & & 0 & & & 0 & 3 & 1 & 0 & - & 0 & 1 & 1 & & 0 & 0 & & & 0 & 0 & 0 & 0 & 0 \\
\hline 1 & 1 & - & 0 & 1 & & & 1 & 0 & 1 & 0 & 0 & & 0 & 1 & 1 & 1 & & & & & 1 & 2 & 1 & 0 & - & 1 & 1 & 1 & & 0 & 0 & & & 0 & 0 & 0 & 0 & 0 \\
\hline 1 & 0 & 0 & 1 & 1 & & & 1 & 0 & 3 & 0 & 0 & & 0 & 1 & 1 & 1 & & & & & 0 & 3 & 1 & 0 & - & 0 & 1 & 1 & & 0 & 0 & & & 0 & 1 & 0 & 0 & 0 \\
\hline 1 & 0 & 0 & 0 & 1 & & & 1 & 0 & 2 & 0 & 0 & & 0 & 0 & 1 & 1 & & & & & 0 & 2 & 1 & 0 & - & 0 & 1 & 1 & & 0 & 0 & & & 0 & 1 & 0 & 0 & 0 \\
\hline 1 & 0 & 0 & 0 & 1 & & & 1 & 0 & 2 & 0 & 0 & & 0 & 1 & 1 & 1 & & & & & 0 & 3 & 1 & 0 & - & 0 & $c$ & 1 & & 0 & 0 & & & 0 & 0 & 0 & 0 & 0 \\
\hline 1 & 0 & 0 & 1 & 1 & & & 1 & 0 & 2 & 0 & 0 & & 0 & 1 & 1 & 1 & & 0 & & & 1 & 3 & 1 & 0 & - & 1 & $c$ & 1 & & 0 & 0 & & & 0 & 0 & & 0 & 0 \\
\hline 1 & 0 & 0 & 0 & 1 & & & 1 & 0 & 1 & 0 & 0 & & 0 & 1 & 1 & 1 & & 0 & & & 0 & 2 & 1 & 0 & - & 0 & 0 & 1 & & 0 & 0 & & & 0 & 0 & 0 & 0 & 0 \\
\hline 1 & 0 & 0 & 1 & 1 & & & 1 & 0 & 1 & 0 & 0 & & 0 & 1 & 1 & 1 & & 0 & & & 0 & 3 & 1 & 0 & - & 0 & 1 & 1 & & 0 & 0 & & & 0 & 0 & 0 & 0 & 0 \\
\hline 1 & 1 & - & 1 & 1 & & & 1 & 0 & 2 & 0 & 0 & & 0 & 0 & 1 & 1 & & & & & 0 & 2 & 1 & 0 & - & 0 & 1 & 1 & & 1 & 0 & & & 0 & 1 & 0 & 0 & 0 \\
\hline 0 & 0 & 0 & 1 & 1 & & & 1 & 0 & - & 3 & 0 & & 0 & 1 & 1 & 1 & & & & & 0 & 2 & 1 & 0 & - & 0 & 1 & 1 & & 0 & 0 & & & - & 0 & 0 & 0 & 0 \\
\hline 1 & 0 & 0 & 1 & 1 & & & 1 & 0 & 2 & 0 & 0 & & 0 & 1 & 1 & 1 & & & & & 0 & 2 & 1 & 0 & - & 0 & $c$ & 1 & & 0 & 0 & & & 0 & 0 & 0 & 0 & 0 \\
\hline 1 & 0 & 0 & 1 & 1 & & & 1 & 0 & 2 & 0 & 0 & & 0 & 1 & 1 & 1 & & 0 & & & 0 & 2 & 1 & 0 & - & 0 & $c$ & 1 & & 0 & 0 & & & 0 & 0 & 0 & 0 & 0 \\
\hline 0 & 0 & 0 & 1 & 1 & 0 & 0 & 1 & 0 & 1 & 0 & 0 & 0 & 0 & 0 & 1 & 1 & 1 & 0 & & & 0 & 3 & 1 & 0 & - & 0 & 0 & 1 & & 0 & & & & & 1 & & 0 & 0 \\
\hline
\end{tabular}


Chappuisiotes lobeliae Adelopsis leo

Adelopsis rostrata

Amplexella dimorpha

Paulipalpina claudicans

Paulipalpina sp.1

Paulipalpina sp.2

Paulipalpina sp. 3

Parapaulipalpina sp.

Ptomaphagus meximontanus

Ptomaphagus sericatus

Ptomaphaginus palpalis

Ptomaphaminus chapmani

Proptomaphaginus puertoricensis

Baryodirus hammondi

Sciaphyes sibiricus

Agyrtodes labralis

Eupelates transversestrigosus

Camiarus thoracicus

Neopelatops edwardsi

Decuria sp.

Zeadolopus validipes

Colenisia zelandica

Scotocryptus sp.

Hydnodiaetus sp.

Dietta huanuco

Leptinus testaceus

Catopocerus sp.

\begin{tabular}{|c|c|c|c|c|c|c|c|c|c|c|c|c|c|c|c|c|c|c|c|c|c|c|c|c|c|c|c|c|c|}
\hline 1 & 1 & - & 1 & 1 & 0 & 0 & 1 & 1 & - & - & 0 & 0 & 0 & 1 & 1 & 1 & 0 & 0 & 0 & 0 & 0 & 3 & 1 & 0 & - & & 1 & 1 & 1 \\
\hline - & 1 & - & 1 & 1 & 0 & 0 & 1 & 0 & 1 & 0 & 0 & 0 & 0 & 0 & 0 & 0 & 0 & 1 & 0 & 0 & 1 & 2 & 1 & 0 & - & & 0 & 0 & 1 \\
\hline 0 & 1 & - & 1 & 1 & 0 & 0 & 1 & 0 & 1 & 0 & 0 & 0 & 0 & 0 & 0 & 0 & 0 & 1 & 0 & 0 & 1 & 2 & 1 & 0 & - & & 1 & 0 & 1 \\
\hline 1 & 0 & 1 & 1 & 1 & 0 & 0 & 1 & 0 & 1 & 0 & 0 & 0 & 0 & 1 & 0 & 0 & 1 & 1 & 0 & 0 & 1 & 2 & 1 & 0 & - & & 0 & 0 & 1 \\
\hline 1 & 0 & 1 & 1 & 1 & 0 & 0 & 1 & 0 & 1 & 0 & 0 & 0 & 0 & 1 & 0 & 0 & 1 & 1 & 0 & 0 & 1 & 2 & 1 & 0 & - & & 0 & 0 & 1 \\
\hline 1 & 0 & 1 & 1 & 1 & 0 & 0 & 1 & 0 & 1 & 0 & 0 & 0 & 0 & 1 & 0 & 0 & 1 & 1 & 0 & 0 & 1 & 2 & 1 & 0 & - & & 0 & 0 & 1 \\
\hline 1 & 0 & 1 & 1 & 1 & 0 & 0 & 1 & 0 & 1 & 0 & 0 & 0 & 0 & 1 & 0 & 0 & 1 & 1 & 0 & 0 & 1 & 2 & 1 & 0 & - & & 0 & 0 & 1 \\
\hline 1 & 0 & 1 & 1 & 1 & 0 & 0 & 1 & 0 & 1 & 0 & 0 & 0 & 0 & 1 & 0 & 0 & 1 & 1 & 0 & 0 & 1 & 2 & 1 & 0 & - & & 0 & 0 & 1 \\
\hline 1 & 0 & 1 & 1 & 1 & 0 & 0 & 1 & 0 & 1 & 0 & 0 & 0 & 0 & 1 & 0 & 0 & 1 & 1 & 0 & 0 & 1 & 2 & 1 & 0 & - & & 0 & 0 & 1 \\
\hline 1 & 0 & 1 & 1 & 1 & 0 & 0 & 1 & 0 & 1 & 0 & 0 & 0 & 0 & 1 & 0 & 0 & 1 & 1 & 0 & 0 & 1 & 2 & 1 & 0 & - & & 0 & 0 & 1 \\
\hline 1 & 0 & 1 & 1 & 1 & 0 & 0 & 1 & 0 & 1 & 0 & 0 & 0 & 0 & 1 & 0 & 0 & 1 & 1 & 0 & 0 & 1 & 2 & 1 & 0 & - & & 0 & 0 & 1 \\
\hline 1 & 0 & 1 & 1 & 1 & 0 & 0 & 1 & 0 & 1 & 0 & 0 & 0 & 0 & 1 & 0 & 0 & 1 & 1 & 0 & 0 & 1 & 2 & 1 & 0 & - & & 0 & 0 & 1 \\
\hline 1 & 0 & 1 & 1 & 1 & 0 & 0 & 1 & 0 & 1 & 0 & 0 & 0 & 0 & 1 & 0 & 0 & 1 & 1 & 0 & 0 & 1 & 2 & 1 & 0 & - & & 0 & 0 & 1 \\
\hline 1 & 0 & 1 & 1 & 1 & 0 & 0 & 1 & 0 & 1 & 0 & 0 & 0 & 0 & 1 & 0 & 0 & 1 & 1 & 0 & 0 & 1 & 2 & 1 & 0 & - & & 0 & 0 & 1 \\
\hline 1 & 0 & 1 & 1 & 1 & 0 & 0 & 1 & 0 & 2 & 0 & 0 & 0 & 0 & 1 & 0 & 0 & 1 & 1 & 0 & 0 & 1 & 2 & 1 & 0 & - & & 0 & 0 & 1 \\
\hline 1 & 0 & 1 & 1 & 1 & 0 & 0 & 1 & 0 & 2 & 0 & 0 & 0 & 0 & 1 & 0 & 0 & 1 & 1 & 0 & 0 & 1 & 2 & 1 & 0 & - & & 0 & 0 & 1 \\
\hline 1 & ? & ? & ? & ? & ? & 0 & 1 & 0 & 2 & 0 & 0 & 0 & 0 & ? & 0 & ? & 1 & ? & ? & 0 & 1 & 2 & 1 & 0 & - & & 0 & 1 & ? \\
\hline 1 & 1 & - & 1 & 1 & 0 & 0 & 1 & 0 & 1 & 0 & 0 & 0 & 0 & 1 & 1 & 1 & 1 & 0 & 0 & 1 & 0 & 2 & 1 & 0 & - & & 0 & 0 & 1 \\
\hline - & 1 & - & 0 & 0 & 0 & 0 & 1 & 0 & 1 & 0 & 0 & 0 & 0 & 1 & 0 & 0 & 0 & 1 & 0 & 0 & 1 & 2 & 1 & 0 & - & & 0 & 0 & 1 \\
\hline - & 1 & - & 0 & 0 & 0 & 0 & 0 & 0 & 1 & 0 & 0 & 0 & 0 & 1 & 0 & 0 & 0 & 0 & 0 & 0 & 1 & 2 & 1 & 1 & 0 & & 0 & 0 & 0 \\
\hline 0 & 1 & - & 0 & 0 & 0 & 0 & 0 & 0 & 0 & 0 & 0 & 0 & 1 & 1 & 0 & 0 & 0 & 0 & 0 & 0 & 0 & 1 & 1 & 0 & - & & 0 & 0 & 1 \\
\hline 0 & 0 & 0 & 0 & 0 & 0 & 0 & 1 & 0 & 1 & 0 & 0 & 0 & 0 & 0 & 0 & 0 & 0 & 1 & 0 & 0 & 1 & 1 & 0 & 0 & - & & 0 & 0 & 0 \\
\hline - & 0 & 0 & 0 & 0 & 0 & 1 & 0 & 0 & 0 & 0 & 0 & 1 & 0 & 1 & 0 & 1 & 0 & 0 & 1 & 0 & 1 & 3 & 0 & 0 & - & & 0 & 1 & 1 \\
\hline 0 & 0 & 0 & 0 & 0 & 0 & 1 & 0 & 0 & 0 & 1 & 0 & 1 & 0 & 1 & 0 & 1 & 0 & 1 & 0 & 0 & 0 & 3 & 0 & 0 & - & & 0 & 0 & 1 \\
\hline - & 1 & - & 0 & 1 & 0 & 1 & 1 & 0 & 0 & 2 & 1 & 1 & 0 & 1 & 0 & 1 & 0 & 0 & 0 & 0 & 1 & 3 & 1 & 0 & - & & 0 & 0 & 1 \\
\hline- & 0 & 1 & 0 & 0 & 0 & 1 & 1 & 0 & 0 & 1 & 0 & 1 & 0 & 1 & 0 & 1 & 0 & 0 & 0 & 0 & 0 & 3 & 1 & 0 & - & & 1 & 2 & 1 \\
\hline 0 & 1 & - & 0 & 0 & 0 & 0 & 0 & 0 & 0 & 0 & 0 & 0 & 1 & 0 & 0 & 0 & 0 & 1 & 0 & 0 & 1 & 1 & 0 & 0 & - & & 0 & 0 & ? \\
\hline 0 & 0 & 0 & 0 & 0 & 0 & 0 & 0 & 0 & 0 & 2 & 1 & 1 & 0 & 0 & 0 & 0 & 0 & 0 & 1 & 0 & 1 & 1 & 0 & 0 & - & & 0 & 0 & 1 \\
\hline - & 1 & - & 0 & 0 & 0 & 0 & 1 & 0 & 0 & 0 & 0 & 0 & 0 & 1 & 0 & 1 & 0 & 1 & 0 & 0 & 0 & 3 & 1 & 0 & - & & 1 & 0 & 0 \\
\hline- & 1 & - & 0 & 0 & 0 & 0 & 1 & 0 & 0 & 0 & 0 & 0 & 0 & 1 & 0 & 0 & 0 & 0 & 0 & 1 & 0 & 3 & 0 & 0 & - & & 0 & 0 & 1 \\
\hline
\end{tabular}

\section{(Continued)}

\begin{tabular}{|c|c|c|c|c|c|c|c|c|c|c|c|c|c|c|c|c|c|c|c|c|c|c|c|c|c|c|c|c|c|c|}
\hline Characters & 6 & & & & & & & & & 7 & & & & & & & & & & 8 & & & & & & & & & & 9 \\
\hline Taxa & 1 & 2 & 3 & 4 & 5 & 6 & 7 & 8 & 9 & 0 & 1 & 2 & 3 & 4 & 5 & 6 & 7 & 8 & 9 & 0 & 1 & 2 & 3 & 4 & 5 & 6 & 7 & 8 & 9 & 0 \\
\hline Zeanecrophilus prolongatus & 0 & 0 & 0 & 0 & 0 & 0 & 0 & 0 & 0 & 0 & 0 & 0 & 0 & 0 & 0 & 0 & 0 & 0 & 0 & 0 & 0 & 0 & 0 & 0 & 0 & 0 & 0 & 0 & 0 & 0 \\
\hline Anemadus acicularis & 0 & 0 & 0 & 1 & 0 & 1 & 0 & 0 & 0 & 0 & 0 & 0 & 0 & 0 & 0 & 0 & 1 & 0 & 0 & 0 & 0 & 0 & 0 & 0 & 1 & 0 & 0 & 0 & 0 & 0 \\
\hline Speonemadus bolivari & 1 & 0 & 0 & 1 & 0 & 1 & 0 & 0 & 0 & 0 & 0 & 0 & 0 & 0 & 0 & 0 & 1 & 0 & 0 & 0 & 0 & 0 & 0 & 0 & 1 & 0 & 0 & 0 & 0 & 0 \\
\hline Eocatops ophidianus & 1 & 1 & 0 & 1 & 0 & 1 & 0 & 0 & 0 & 0 & 0 & 0 & 0 & 0 & 0 & 0 & 1 & 0 & 0 & 0 & 0 & 0 & 0 & 0 & 1 & 0 & 0 & 0 & 0 & 0 \\
\hline Dissochaetus arizonensis & 1 & 0 & 0 & 1 & 1 & 1 & 0 & 0 & 0 & 0 & 0 & 0 & 1 & 0 & 0 & 1 & 1 & 0 & 0 & 0 & 0 & 0 & 0 & 0 & 1 & 1 & 0 & 0 & 0 & 0 \\
\hline Dissochaetus vanini & 1 & 0 & 0 & 1 & 1 & 1 & 0 & 0 & 0 & 0 & 0 & 0 & 1 & 0 & 0 & 1 & 1 & 0 & 0 & 0 & 0 & 0 & 0 & 0 & 1 & 1 & 0 & 0 & 0 & 0 \\
\hline
\end{tabular}


Falkocholeva sp.

Nargiotes leptocerus

Nargomorphus amplicollis

Pseudonemadus cheesmani

Nemadus sp.

Micronemadus pussilimus

Paracatops alacris

Paracatops antipoda

Apocatops monguzzii

Catops fuliginosus

Catops subfuscus

Cholevinus fuscipes

Sciodrepoides watsoni

Rybinskiella magnifica

Catopsimorphus orientalis

Choleva agilis

Choleva oblonga

Nargus badius

Prionochaeta

Eucatops sp.1

Eucatops sp.2

Antroherpon

Hadesia vasiceki

Remyella scaphoides droveniki

Aphaobius milleri springeri

Aphaotus jureceki

Bathyscia montana

Oryotus schmidti

Pisidiella kosswigi

Bathysciotes khevenhuelleri

Neobathyscia fabianii

Ravasinia lonae

Speonesiotes sp.

Antrosedes speluncarius

Apholeuonus longicollis

Astagobius angustatus laticollis

Elladoherpon inopinatum

Haplotropidius pubescens

Leptodirus hochenwarti

Pholeuonidius halbherri

Speoplanes giganteus biocovensis

Albaniola thessalica

\begin{tabular}{|c|c|c|c|c|c|c|c|c|c|c|c|c|c|c|c|c|c|c|c|c|c|c|c|c|c|c|c|}
\hline 1 & 1 & 0 & 1 & 1 & 1 & 1 & 0 & 0 & 0 & 0 & 0 & 1 & 0 & 0 & 1 & 1 & 0 & 0 & 0 & 0 & 0 & 0 & 0 & & & 0 & 0 \\
\hline 1 & 0 & 0 & 1 & 0 & 1 & 0 & 0 & 0 & 0 & 0 & 0 & 1 & 0 & 1 & 1 & 1 & 0 & 0 & 0 & 0 & 0 & 0 & 0 & & & 0 & 0 \\
\hline 1 & 0 & 0 & 2 & 1 & 1 & 0 & 0 & 0 & 0 & 0 & 0 & 1 & 0 & 1 & 1 & 1 & 0 & 0 & 0 & 0 & 0 & 0 & 0 & & & 0 & 0 \\
\hline 1 & 0 & 0 & 1 & 1 & 1 & 0 & 0 & 0 & 0 & 0 & 0 & 1 & 0 & 0 & 1 & 1 & 0 & 0 & 0 & 0 & 0 & 0 & c & & & 0 & 0 \\
\hline 0 & 0 & 0 & 2 & 1 & 2 & 0 & 0 & 0 & 0 & 0 & 0 & 1 & 0 & 0 & 0 & 1 & 0 & 0 & 0 & 0 & 0 & 0 & c & & & 0 & 0 \\
\hline 0 & 0 & 0 & 2 & ? & 2 & 0 & 0 & 0 & 0 & 0 & 0 & 0 & 0 & 0 & 0 & 1 & 0 & 0 & 0 & 0 & 0 & 0 & c & & & 1 & 1 \\
\hline 1 & 0 & 0 & 1 & 1 & 1 & 1 & 0 & 0 & 0 & 0 & 0 & 1 & 0 & 0 & 1 & 1 & 0 & 0 & 0 & 0 & 0 & 0 & 0 & & & 0 & 0 \\
\hline 1 & 1 & 0 & 1 & 1 & 1 & 1 & 0 & 0 & 0 & 0 & 0 & 1 & 0 & 0 & 1 & 1 & 0 & 0 & 0 & 0 & 0 & 0 & c & & & 0 & 0 \\
\hline 0 & 0 & 0 & 1 & 1 & 1 & 1 & 0 & 0 & 0 & 0 & 0 & 0 & 0 & 0 & 0 & 1 & 0 & 0 & 0 & 0 & 0 & 0 & 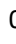 & & & 0 & 0 \\
\hline 1 & 0 & 0 & 1 & 1 & 1 & 0 & 0 & 0 & 0 & 0 & 0 & 0 & 0 & 0 & 0 & 1 & 0 & 0 & 0 & 0 & 0 & 0 & 0 & & & 0 & 0 \\
\hline 1 & 0 & 0 & 1 & 1 & 1 & 0 & 0 & 0 & 0 & 0 & 0 & 0 & 0 & 0 & 0 & 1 & 0 & 0 & 0 & 0 & 0 & 0 & c & & & 0 & 0 \\
\hline 1 & 1 & 0 & 1 & 0 & 1 & 0 & 0 & 0 & 0 & 0 & 0 & 0 & 0 & 0 & 0 & 1 & 0 & 0 & 0 & 0 & 0 & 0 & c & & & 0 & 0 \\
\hline 1 & 0 & 0 & 1 & 1 & 1 & 0 & 0 & 0 & 0 & 0 & 0 & 0 & 0 & 0 & 0 & 1 & 0 & 0 & 0 & 0 & 0 & 0 & c & & & 0 & 0 \\
\hline 0 & 0 & 0 & 1 & 0 & 1 & 0 & 0 & 0 & 0 & 0 & 0 & 0 & 0 & 0 & 0 & 1 & 0 & 0 & 0 & 0 & 0 & 0 & 0 & & & 0 & 0 \\
\hline 1 & 0 & 0 & 1 & 0 & 1 & 0 & 0 & 0 & 0 & 0 & 0 & 0 & 0 & 0 & 0 & 1 & 0 & 0 & 0 & 2 & 0 & 0 & c & & & 0 & 0 \\
\hline 1 & 0 & 0 & 1 & 0 & 1 & 0 & 0 & 0 & 0 & 0 & 0 & $0 \& 1$ & 0 & 0 & 0 & 1 & 0 & 0 & 0 & 2 & 0 & 0 & c & & & 0 & 0 \\
\hline 1 & 0 & 0 & 1 & 0 & 1 & 0 & 0 & 0 & 0 & 0 & 0 & 0 & 0 & 0 & 0 & 1 & 0 & 0 & 0 & 2 & 0 & 0 & 0 & & & 0 & 0 \\
\hline 1 & 0 & 0 & 2 & 0 & 1 & 0 & 0 & 0 & 0 & 0 & 0 & $0 \& 1$ & 0 & 0 & 0 & 1 & 0 & 0 & 0 & 2 & 0 & 0 & c & & & 0 & 0 \\
\hline 1 & 1 & 0 & 1 & 1 & 1 & 0 & 0 & 0 & 0 & 0 & 0 & 0 & 0 & 0 & 0 & 1 & 0 & 0 & 0 & 0 & 0 & 0 & c & & & 0 & 0 \\
\hline 0 & 0 & 0 & 1 & 1 & 1 & 0 & 0 & 1 & 0 & 0 & 0 & 0 & 0 & 0 & 0 & 0 & 0 & 0 & 0 & 0 & 0 & 0 & c & & & 0 & 0 \\
\hline 0 & 0 & 0 & 1 & 1 & 2 & 0 & 0 & 1 & 0 & 0 & 0 & 0 & 0 & 0 & 0 & 0 & 0 & 0 & 0 & 0 & 0 & 0 & 0 & & & 0 & 0 \\
\hline 1 & 0 & 1 & 2 & 0 & 2 & 0 & 0 & 0 & 0 & 0 & 0 & 0 & 0 & 0 & 0 & 1 & 0 & 0 & 0 & 0 & 0 & 0 & 0 & & & 0 & 0 \\
\hline 0 & 0 & 0 & 0 & 0 & 0 & 0 & 0 & 0 & 0 & 0 & 0 & 0 & 0 & 0 & 0 & 1 & 0 & 0 & 0 & 0 & 0 & 0 & c & & & 0 & 0 \\
\hline 1 & 0 & 1 & 2 & 0 & 2 & 0 & 0 & 0 & 0 & 0 & 0 & 0 & 0 & 0 & 0 & 1 & 1 & 1 & 0 & 0 & 0 & 0 & 0 & & & 0 & 0 \\
\hline 1 & 0 & 1 & 2 & 0 & 2 & 0 & 0 & 0 & 0 & 0 & 0 & 0 & 0 & 0 & 0 & 1 & 1 & 1 & 0 & 0 & 0 & 0 & $c$ & & & 0 & 0 \\
\hline 1 & 0 & 1 & 2 & 0 & 2 & 0 & 0 & 0 & 0 & 0 & 0 & 0 & 0 & 0 & 0 & 1 & 1 & 1 & 0 & 0 & 0 & 0 & 0 & & & 0 & 0 \\
\hline 1 & 0 & 0 & 2 & 0 & 2 & 0 & 0 & 0 & 0 & 0 & 0 & 0 & 0 & 0 & 0 & 1 & 1 & 1 & 0 & 0 & 0 & 0 & 0 & & & 0 & 0 \\
\hline 1 & 0 & 1 & 2 & 0 & 2 & 0 & 0 & 0 & 0 & 0 & 0 & 0 & 0 & 0 & 0 & 1 & 1 & 1 & 0 & 0 & 0 & 0 & 0 & & & 0 & 0 \\
\hline 1 & 0 & 1 & 2 & 0 & 2 & 0 & 0 & 0 & 0 & 0 & 0 & 0 & 0 & 0 & 0 & 1 & 1 & 1 & 0 & 0 & 0 & 0 & $c$ & & & 0 & 0 \\
\hline 1 & 0 & 1 & 2 & 0 & 2 & 0 & 0 & 0 & 0 & 0 & 0 & 0 & 0 & 0 & 0 & 1 & 1 & 1 & 0 & 0 & 0 & 0 & 0 & & & 0 & 0 \\
\hline 1 & 0 & 1 & 2 & 0 & 2 & 0 & 0 & 0 & 0 & 0 & 0 & 0 & 0 & 0 & 0 & 1 & 1 & 1 & 0 & 0 & 0 & 0 & $c$ & & & 0 & 0 \\
\hline 1 & 0 & 1 & 2 & 0 & 2 & 0 & 0 & 0 & 0 & 0 & 0 & 0 & 0 & 0 & 0 & 1 & 1 & 1 & 0 & 0 & 0 & 0 & $c$ & & & 0 & 0 \\
\hline 1 & 0 & 1 & 2 & 0 & 2 & 0 & 0 & 0 & 0 & 0 & 0 & 0 & 0 & 0 & 0 & 1 & 1 & 1 & 0 & 0 & 0 & 0 & $c$ & & & 0 & 0 \\
\hline 1 & 0 & 0 & 2 & 0 & 2 & 0 & 0 & 0 & 0 & 0 & 0 & 0 & 0 & 0 & 0 & 1 & 1 & 1 & 0 & 0 & 0 & 0 & 0 & & & 0 & 0 \\
\hline 1 & 0 & 1 & 2 & 0 & 2 & 0 & 0 & 0 & 0 & 0 & 0 & 0 & 0 & 0 & 0 & 1 & 1 & 1 & 0 & 0 & 0 & 0 & 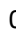 & & & 0 & 0 \\
\hline 1 & 0 & 1 & 2 & 0 & 2 & 0 & 0 & 0 & 0 & 0 & 0 & 0 & 0 & 0 & 0 & 1 & 1 & 1 & 0 & 0 & 0 & 0 & $c$ & & & 0 & 0 \\
\hline 1 & 0 & 1 & 2 & 0 & 2 & 0 & 0 & 0 & 0 & 0 & 0 & 0 & 1 & 0 & 0 & 1 & 1 & 1 & 0 & 0 & 0 & 0 & c & & & 0 & 0 \\
\hline 1 & 0 & 1 & 2 & 0 & 2 & 0 & 0 & 0 & 0 & 0 & 0 & 0 & 0 & 0 & 0 & 1 & 1 & 1 & 0 & 0 & 0 & 0 & 0 & & & 0 & 0 \\
\hline 1 & 0 & 1 & 2 & 0 & 2 & 0 & 0 & 0 & 0 & 0 & 0 & 0 & 0 & 0 & 0 & 1 & 1 & 1 & 0 & 0 & 0 & 0 & 0 & & & 0 & 0 \\
\hline 1 & 0 & ? & 2 & 0 & 2 & 0 & 0 & 0 & 0 & 0 & 0 & 0 & 0 & 0 & 0 & 1 & 1 & 1 & 0 & 0 & 0 & 0 & c & & & 0 & 0 \\
\hline 1 & 0 & 1 & 2 & 0 & 2 & 0 & 0 & 0 & 0 & 0 & 0 & 0 & 0 & 0 & 0 & 1 & 1 & 1 & 0 & 0 & 0 & 0 & $c$ & & & 0 & 0 \\
\hline 1 & 0 & 0 & 2 & 0 & 2 & 0 & 0 & 0 & 0 & 0 & 0 & 0 & 0 & 0 & 0 & 1 & 1 & 1 & 0 & 0 & 0 & 0 & 0 & & & 0 & 0 \\
\hline
\end{tabular}


Antrocharis querilhaci Beskovia bulgarica

Breuilia triangulum

Canavesiella lanai

Dellabeffaella roccae

Quaestus arcanus

Notidocharis ovoideus

Parabathyscia ligurica

Paraspeonomus vandeli

Paratroglophyes jeanneli

Pholeuon knirschi

Pseudoboldoria robiati

Speonomus infernus

Troglocharinus ferreri

Troglodromus bucheti caussicola

\section{Platycholeus}

Spelaeobates kraussi

Afrocatops sp.

Chappuisiotes lobeliae

Adelopsis leo

Adelopsis rostrata

Amplexella dimorpha

Paulipalpina claudicans

Paulipalpina sp.1

Paulipalpina sp.2

Paulipalpina sp. 3

Parapaulipalpina sp.

Ptomaphagus meximontanus

Ptomaphagus sericatus

Ptomaphaginus palpalis

Ptomaphaminus chapman

Proptomaphaginus puertoricensis

Baryodirus hammondi

Sciaphyes sibiricus

Agyrtodes labralis

Eupelates transversestrigosus

Camiarus thoracicus

Neopelatops edwardsi

Decuria sp.

Zeadolopus validipes

Colenisia zelandica

Scotocryptus sp.

\begin{tabular}{|c|c|c|c|c|c|c|c|c|c|c|c|c|c|c|c|c|c|c|c|c|c|c|c|c|c|c|c|c|c|}
\hline 1 & 0 & 1 & 2 & 0 & 2 & 0 & 0 & 0 & 0 & 0 & 0 & 0 & 0 & 0 & 0 & 1 & 1 & 1 & 0 & 1 & 0 & 0 & 0 & 2 & 0 & 0 & 0 & 0 & 1 \\
\hline 1 & 0 & ? & 0 & 0 & 0 & 0 & 0 & 0 & 0 & 0 & 0 & 0 & 0 & 0 & 0 & 1 & - & - & 1 & - & 0 & 0 & 0 & 2 & 0 & 0 & 0 & 0 & 1 \\
\hline 1 & 0 & 1 & 2 & 0 & 2 & 0 & 0 & 0 & 0 & 0 & 0 & 0 & 0 & 0 & 0 & 1 & 1 & 1 & 0 & 0 & 0 & 0 & 0 & 2 & 0 & 0 & 0 & 0 & 1 \\
\hline 1 & 0 & 1 & 2 & 0 & 2 & 0 & 0 & 0 & 0 & 0 & 0 & 0 & 0 & 0 & 0 & 1 & 1 & 1 & 0 & 0 & 0 & 0 & 0 & 2 & 0 & 0 & 0 & 0 & 1 \\
\hline 1 & 0 & 1 & 2 & 0 & 2 & 0 & 0 & 0 & 0 & 0 & 0 & 0 & 0 & 0 & 0 & 1 & 1 & 1 & 0 & 0 & 0 & 0 & 0 & 2 & 0 & 0 & 0 & 0 & 1 \\
\hline 1 & 0 & 0 & 2 & 0 & 2 & 0 & 0 & 0 & 0 & 0 & 0 & 0 & 0 & 0 & 0 & 1 & 1 & 1 & 0 & 0 & 0 & 0 & 0 & 2 & 0 & 0 & 0 & 0 & 1 \\
\hline 1 & 0 & 0 & 2 & 0 & 2 & 0 & 0 & 0 & 0 & 0 & 0 & 0 & 0 & 0 & 0 & 1 & 0 & 1 & 0 & 1 & 0 & 0 & 0 & 1 & 0 & 0 & 0 & 0 & 1 \\
\hline 1 & 0 & 1 & 2 & 0 & 2 & 0 & 0 & 0 & 0 & 0 & 0 & 0 & 1 & 0 & 0 & 1 & 1 & 1 & 0 & 1 & 0 & 0 & 0 & 2 & 0 & 0 & 0 & 0 & 1 \\
\hline 1 & 0 & 1 & 2 & 0 & 2 & 0 & 0 & 0 & 0 & 0 & 0 & 0 & 0 & 0 & 0 & 1 & 1 & 1 & 0 & 1 & 0 & 0 & 0 & 2 & 0 & 0 & 0 & 0 & 1 \\
\hline 1 & 0 & 1 & 2 & 0 & 2 & 0 & 0 & 0 & 0 & 0 & 0 & 0 & 0 & 0 & 0 & 1 & 1 & 1 & 0 & 1 & 0 & 0 & 0 & 2 & 0 & 0 & 0 & 0 & 1 \\
\hline 1 & 0 & 0 & 2 & 0 & 2 & 0 & 0 & 0 & 0 & 0 & 0 & 0 & 0 & 0 & 0 & 1 & - & 1 & 0 & $0 \& 1$ & 0 & 0 & 0 & 2 & 0 & 0 & 0 & 0 & 1 \\
\hline 1 & 0 & 1 & 2 & 0 & 2 & 0 & 0 & 0 & 0 & 0 & 0 & 0 & 0 & 0 & 0 & 1 & 1 & 1 & 0 & 0 & 0 & 0 & 0 & 2 & 0 & 0 & 0 & 0 & 1 \\
\hline 1 & 0 & 1 & 2 & 0 & 2 & 0 & 0 & 0 & 0 & 0 & 0 & 0 & 0 & 0 & 0 & 1 & 1 & 1 & 0 & 1 & 0 & 0 & 0 & 2 & 0 & 0 & 0 & 0 & 1 \\
\hline 1 & 0 & $?$ & 2 & 0 & 2 & 0 & 0 & 0 & 0 & 0 & 0 & 0 & 0 & 0 & 0 & 1 & 1 & 1 & 0 & 1 & 0 & 0 & 0 & 2 & 0 & 0 & 0 & 0 & 1 \\
\hline 1 & 0 & 1 & 2 & 0 & 2 & 0 & 0 & 0 & 0 & 0 & 0 & 0 & 0 & 0 & 0 & 1 & 1 & 1 & 0 & 1 & 0 & 0 & 0 & 2 & 0 & 0 & 0 & 0 & 1 \\
\hline 0 & 0 & 0 & 2 & 0 & 2 & 0 & 0 & 0 & 0 & 0 & 0 & 0 & 0 & 0 & 0 & 1 & - & - & 1 & - & 0 & 0 & 0 & 1 & 0 & 0 & 0 & 0 & 0 \\
\hline 1 & 0 & 0 & 2 & 0 & 2 & 0 & 0 & 0 & 0 & 0 & 0 & 0 & 0 & 0 & 0 & 1 & 1 & 1 & 0 & 0 & 0 & 0 & 0 & 2 & 0 & 0 & 0 & 0 & 1 \\
\hline 0 & 0 & 0 & 1 & 1 & 1 & 0 & 0 & 1 & 0 & 0 & 0 & 0 & 0 & 0 & 0 & 0 & 0 & 0 & 0 & 0 & 0 & 0 & 0 & 1 & 0 & 0 & 0 & 0 & 0 \\
\hline 0 & 0 & 0 & 1 & 0 & 1 & 0 & 0 & 0 & 0 & 0 & 0 & 0 & 0 & 0 & 0 & 0 & 0 & 0 & 0 & 0 & 0 & 0 & 0 & 1 & 0 & 0 & 0 & 0 & 0 \\
\hline 0 & 0 & 0 & 2 & 0 & 2 & 0 & 0 & 0 & 0 & 1 & 0 & 0 & 0 & 0 & 0 & 1 & 0 & 0 & 0 & 0 & 0 & 0 & 0 & 1 & 0 & 0 & 1 & 1 & 0 \\
\hline 0 & 0 & 0 & 2 & 0 & 2 & 0 & 0 & 0 & 0 & 1 & 0 & 0 & 0 & 0 & 0 & 1 & 0 & 0 & 0 & 0 & 0 & 0 & 0 & 1 & 0 & 0 & 1 & 1 & 0 \\
\hline 0 & 0 & 0 & 2 & 0 & 2 & 0 & 0 & 0 & 0 & 1 & 0 & 0 & 0 & 0 & 0 & 1 & 0 & 0 & 0 & 0 & 0 & 0 & 0 & 1 & 0 & 0 & 1 & 1 & 0 \\
\hline 0 & 0 & 0 & 2 & 0 & 2 & 0 & 0 & 0 & 1 & 1 & 1 & 0 & 0 & 0 & 0 & 1 & 0 & 0 & 0 & 0 & 0 & 1 & 1 & 1 & 0 & 0 & 1 & 1 & 0 \\
\hline 0 & 0 & 0 & 2 & 0 & 2 & 0 & 0 & 0 & 1 & 1 & 1 & 0 & 0 & 0 & 0 & 1 & 0 & 0 & 0 & 0 & 0 & 1 & 1 & 1 & 0 & 0 & 1 & 1 & 0 \\
\hline 0 & 0 & 0 & 2 & 0 & 2 & 0 & 0 & 0 & 1 & 1 & 1 & 0 & 0 & 0 & 0 & 1 & 0 & 0 & 0 & 0 & 0 & 1 & 1 & 1 & 0 & 0 & 1 & 1 & 0 \\
\hline 0 & 0 & 0 & 2 & 0 & 2 & 0 & 0 & 0 & 1 & 1 & 1 & 0 & 0 & 0 & 0 & 1 & 0 & 0 & 0 & 0 & 0 & 1 & 1 & 1 & 0 & 0 & 1 & 1 & 0 \\
\hline 0 & 0 & 0 & 2 & 0 & 2 & 0 & 0 & 0 & 0 & 1 & 0 & 0 & 0 & 0 & 0 & 1 & 0 & 0 & 0 & 0 & 0 & 0 & 0 & 1 & 0 & 0 & 1 & 1 & 0 \\
\hline 0 & 0 & 0 & 2 & 0 & 2 & 0 & 0 & 0 & 0 & 1 & 0 & 0 & 0 & 0 & 0 & 1 & 0 & 0 & 0 & 0 & 0 & 0 & 0 & 1 & 0 & 0 & 1 & 1 & 0 \\
\hline 0 & 0 & 0 & 2 & 1 & 2 & 0 & 0 & 0 & 0 & 1 & 0 & 1 & 0 & 0 & 0 & 1 & 0 & 0 & 0 & 0 & 0 & 0 & 0 & 1 & 0 & 0 & 1 & 1 & 0 \\
\hline 0 & 0 & 0 & 2 & 0 & 2 & 0 & 0 & 0 & 0 & 1 & 0 & 0 & 0 & 0 & 0 & 1 & 0 & 0 & 0 & 0 & 0 & 0 & 0 & 1 & 1 & 0 & 0 & 1 & 0 \\
\hline 0 & 0 & 0 & 2 & 0 & 2 & 0 & 0 & 0 & 0 & 1 & 0 & 0 & 0 & 0 & 0 & 1 & 0 & 0 & $0 \& 1$ & - & 1 & 1 & 0 & 1 & 1 & 0 & 0 & 1 & 0 \\
\hline 0 & 0 & 0 & 2 & 0 & 2 & 0 & 0 & 0 & 0 & 1 & 0 & 0 & 0 & 0 & 0 & 1 & 0 & 0 & 0 & 0 & 0 & 0 & 0 & 1 & 1 & 0 & 0 & 1 & 0 \\
\hline ? & ? & ? & 2 & 0 & 2 & 0 & 0 & 0 & 0 & ? & ? & $?$ & ? & ? & ? & 1 & 0 & 0 & 0 & 0 & 0 & 0 & 1 & ? & 1 & 0 & 0 & ? & ? \\
\hline 1 & 0 & 0 & 1 & 0 & 1 & 0 & 0 & 0 & 0 & 0 & 0 & 0 & 0 & 0 & 0 & 1 & 0 & 0 & 0 & 0 & 0 & 0 & 0 & 2 & 0 & 1 & 0 & 0 & 1 \\
\hline 0 & 0 & 0 & 1 & 0 & 1 & 0 & 0 & 0 & 0 & 0 & 0 & 0 & 0 & 0 & 0 & 0 & 0 & 0 & 0 & 0 & 0 & 0 & 0 & 1 & 0 & 0 & 0 & 0 & 0 \\
\hline 0 & 0 & 0 & 1 & 0 & 1 & 0 & 0 & 0 & 0 & 0 & 0 & 0 & 0 & 0 & 0 & 0 & 0 & 0 & 0 & 0 & 0 & 0 & 0 & 1 & 0 & 0 & 0 & 0 & 0 \\
\hline 0 & 0 & 0 & 1 & 0 & 1 & 0 & 0 & 0 & 0 & 0 & 0 & 0 & 0 & 0 & 0 & 0 & - & - & 1 & - & 0 & 0 & 0 & 2 & 0 & 0 & 0 & 0 & 0 \\
\hline 0 & 0 & 0 & 1 & 1 & 1 & 1 & 1 & 0 & 0 & 0 & 0 & 0 & 0 & 0 & 0 & 0 & 0 & 0 & 0 & 0 & 0 & 0 & 0 & 1 & 0 & 0 & 0 & 0 & 0 \\
\hline 0 & 0 & 0 & 1 & 1 & 1 & 1 & 1 & 1 & 0 & 0 & 0 & 0 & 0 & 0 & 0 & 1 & 0 & 0 & 0 & 0 & 0 & 0 & 0 & 2 & 0 & 0 & 0 & 0 & 0 \\
\hline 0 & 0 & 0 & 1 & 0 & 1 & 0 & 0 & 0 & 0 & 0 & 0 & 0 & 0 & 0 & 0 & 1 & 0 & 0 & 0 & 0 & 0 & 0 & 0 & 2 & 0 & 0 & 0 & 0 & 0 \\
\hline 0 & 0 & 0 & 1 & 0 & 1 & 0 & 0 & 0 & 0 & 0 & 0 & 0 & 0 & 0 & 0 & 1 & 0 & 0 & 0 & 0 & 0 & 0 & 0 & 2 & 0 & 0 & 0 & 0 & 0 \\
\hline 0 & 0 & 0 & 1 & 0 & 1 & 0 & 0 & 0 & 0 & 0 & 0 & 0 & 0 & 0 & 0 & 1 & 0 & 0 & 0 & 0 & 0 & 0 & 0 & 2 & 0 & 0 & 0 & 0 & 0 \\
\hline
\end{tabular}




$0 \quad 0$

$0 \quad 0 \quad 0$

(Continued)

\begin{tabular}{llllllll}
\hline & Characters & 9 & & & & & \\
Taxa & 1 & 2 & 3 & 4 & 5 & 6 & 7 \\
\hline Zeanecrophilus prolongatus & 0 & 0 & 0 & 0 & - & - & 0 \\
Anemadus acicularis & 0 & 0 & 0 & 1 & 0 & 1 & 0 \\
Speonemadus bolivari & 0 & 0 & 0 & 1 & 0 & 1 & 0 \\
Eocatops ophidianus & 0 & 0 & 0 & 1 & 0 & 1 & 0 \\
Dissochaetus arizonensis & 0 & 0 & 0 & 1 & 0 & 1 & 0 \\
Dissochaetus vanini & 0 & 0 & 0 & 1 & 0 & 1 & 0 \\
Falkocholeva sp. & 0 & 0 & 0 & 1 & 0 & 1 & 0 \\
Nargiotes leptocerus & 0 & 0 & 0 & 1 & 0 & 1 & 0 \\
Nargomorphus amplicollis & 0 & 0 & 0 & 1 & 0 & 1 & 0 \\
Pseudonemadus cheesmani & 0 & 0 & 0 & 1 & 0 & 1 & 0 \\
Nemadus sp. & 0 & 0 & 0 & 1 & 0 & 1 & 0 \\
Micronemadus pussilimus & 0 & 0 & 0 & 1 & 0 & 1 & 0 \\
Paracatops alacris & 0 & 0 & 0 & 1 & 0 & 1 & 1 \\
Paracatops antipoda & 0 & 0 & 0 & 1 & 0 & 1 & 1 \\
Apocatops monguzzii & 0 & 0 & 0 & 1 & 1 & 1 & 0 \\
Catops fuliginosus & 0 & 0 & 0 & 1 & 1 & 1 & 0 \\
Catops subfuscus & 0 & 0 & 0 & 1 & 1 & 1 & 0 \\
Cholevinus fuscipes & 0 & 0 & 0 & 1 & 1 & 1 & 0 \\
Sciodrepoides watsoni & 0 & 0 & 0 & 1 & 1 & 1 & 0 \\
Rybinskiella magnifica & 0 & 0 & 0 & 1 & 1 & 1 & 0 \\
Catopsimorphus orientalis & 0 & 0 & 0 & 1 & 0 & 1 & 0 \\
Choleva agilis & 0 & 0 & 0 & 1 & 0 & 1 & 0 \\
Choleva oblonga & 0 & 0 & 0 & 1 & 0 & 1 & 0 \\
Nargus badius & 0 & 0 & 1 & 1 & 0 & 1 & 0 \\
Prionochaeta & 0 & 0 & 0 & 1 & 0 & 1 & 0 \\
Eucatops sp.1 & 0 & 0 & 0 & 1 & 0 & 1 & 1 \\
Eucatops sp.2 & 0 & 0 & 0 & 1 & 0 & 1 & 1 \\
Antroherpon & 0 & 0 & 0 & 1 & 0 & 1 & 0 \\
Hadesia vasiceki & 0 & 0 & 0 & 1 & 0 & 1 & 0 \\
Remyella scaphoides droveniki & 0 & 0 & 0 & 1 & 0 & 1 & 0 \\
& & & & & & &
\end{tabular}

Aphaobius milleri springeri Aphaotus jureceki

Bathyscia montana

Oryotus schmidti

Pisidiella kosswigi

Bathysciotes khevenhuelleri

Neobathyscia fabianii

Ravasinia lonae

Speonesiotes sp.

Antrosedes speluncarius

Apholeuonus longicollis

Astagobius angustatus laticollis

Elladoherpon inopinatum

Haplotropidius pubescens

Leptodirus hochenwarti

Pholeuonidius halbherri

Speoplanes giganteus biocovensis

Albaniola thessalica

Antrocharis querilhaci

Beskovia bulgarica

Breuilia triangulum

Canavesiella lanai

Dellabeffaella roccae

Quaestus arcanus

Notidocharis ovoideus

Parabathyscia ligurica

Paraspeonomus vandeli

Paratroglophyes jeanneli

Pholeuon knirschi

Pseudoboldoria robiati

Speonomus infernus

Troglocharinus ferreri

$\begin{array}{lllllll}0 & 0 & 0 & 1 & 0 & 1 & 0 \\ 0 & 0 & 0 & 1 & 0 & 1 & 0 \\ 0 & 0 & 0 & 1 & 0 & 1 & 0 \\ 0 & 0 & 0 & 1 & 0 & 1 & 0 \\ 0 & 0 & 0 & 1 & 0 & 1 & 0 \\ 0 & 0 & 0 & 1 & 0 & 1 & 0 \\ 0 & 0 & 0 & 1 & 0 & 1 & 0 \\ 0 & 0 & 0 & 1 & 0 & 1 & 0 \\ 0 & 0 & 0 & 1 & 0 & 1 & 0 \\ 0 & 0 & 0 & 1 & 0 & 1 & 0 \\ 0 & 0 & 0 & 1 & 0 & 1 & 0 \\ 0 & 0 & 0 & 1 & 0 & 1 & 0 \\ 0 & 0 & 0 & 1 & 0 & 1 & 0 \\ 0 & 0 & 0 & 1 & 0 & 1 & 0 \\ 0 & 0 & 0 & 1 & 0 & 1 & 0 \\ 0 & 0 & 0 & 1 & 0 & 1 & 0 \\ 0 & 0 & 0 & 1 & 0 & 1 & 0 \\ 0 & 0 & 0 & 1 & 0 & 1 & 0 \\ 0 & 0 & 0 & 1 & 0 & 1 & 0 \\ 0 & 0 & 0 & 1 & 0 & 1 & 0 \\ 0 & 0 & 0 & 1 & 0 & 1 & 0 \\ 0 & 0 & 0 & 1 & 0 & 1 & 0 \\ 0 & 0 & 0 & 1 & 0 & 1 & 0 \\ 0 & 0 & 0 & 1 & 0 & 1 & 0 \\ 0 & 0 & 0 & 1 & 0 & 1 & 0 \\ 0 & 0 & 0 & 1 & 0 & 1 & 0 \\ 0 & 0 & 0 & 1 & 0 & 1 & 0 \\ 0 & 0 & 0 & 1 & 0 & 1 & 0 \\ 0 & 0 & 0 & 1 & 0 & 1 & 0 \\ 0 & 0 & 0 & 1 & 0 & 1 & 0 \\ 0 & 0 & 0 & 1 & 0 & 1 & 0 \\ 0 & 0 & 0 & 1 & 0 & 1 & 0\end{array}$




\begin{tabular}{llllllll} 
Troglodromus bucheti caussicola & 0 & 0 & 0 & 1 & 0 & 1 & 0 \\
Platycholeus & 0 & 0 & 0 & 1 & 0 & 1 & 0 \\
Spelaeobates kraussi & 0 & 0 & 0 & 1 & 0 & 1 & 0 \\
Afrocatops sp. & 0 & 0 & 0 & 1 & 0 & 1 & 0 \\
Chappuisiotes lobeliae & 0 & 0 & 0 & 1 & 0 & 1 & 0 \\
Adelopsis leo & 0 & 0 & 1 & 0 & 0 & 0 & 1 \\
Adelopsis rostrata & 0 & 0 & 1 & 0 & 0 & 0 & 1 \\
Amplexella dimorpha & 0 & 0 & 1 & 0 & 0 & 0 & 1 \\
Paulipalpina claudicans & 0 & 0 & 1 & 0 & 0 & 0 & 1 \\
Paulipalpina sp.1 & 0 & 0 & 1 & 0 & 0 & 0 & 1 \\
Paulipalpina sp.2 & 0 & 0 & 1 & 0 & 0 & 0 & 1 \\
Paulipalpina sp.3 & 0 & 0 & 1 & 0 & 0 & 0 & 1 \\
Parapaulipalpina sp. & 0 & 0 & 1 & 0 & 0 & 0 & 1 \\
Ptomaphagus meximontanus & 0 & 0 & 1 & 0 & 0 & 0 & 1 \\
Ptomaphagus sericatus & 0 & 0 & 1 & 0 & 0 & 0 & 1 \\
Ptomaphaginus palpalis & 0 & 0 & 1 & 0 & 0 & 0 & 1 \\
Ptomaphaminus chapmani & 0 & 0 & 1 & 0 & 0 & 0 & 1 \\
Proptomaphaginus puertoricensis & 0 & 0 & 0 & 0 & 0 & 0 & 1 \\
Baryodirus hammondi & $?$ & $?$ & $?$ & $?$ & $?$ & $?$ & $?$ \\
Sciaphyes sibiricus & 0 & 1 & 0 & 1 & 0 & 1 & 0 \\
Agyrtodes labralis & 0 & 0 & 0 & 1 & 0 & 1 & 0 \\
Eupelates transversestrigosus & 0 & 0 & 0 & 1 & 0 & 1 & 0 \\
Camiarus thoracicus & 0 & 0 & 0 & 1 & 0 & 1 & 0 \\
Neopelatops edwardsi & 0 & 0 & 0 & 0 & 1 & 1 & 1 \\
Decuria sp. & 0 & 0 & 0 & 0 & 0 & 1 & 0 \\
Zeadolopus validipes & 0 & 0 & 0 & 1 & 0 & 1 & 0 \\
Colenisia zelandica & 0 & 0 & 0 & 0 & 0 & 1 & 1 \\
Scotocryptus sp. & 0 & 0 & 0 & 0 & 0 & 0 & 1 \\
Hydnodiaetus sp. & 0 & 0 & 0 & $?$ & 0 & 1 & 0 \\
Dietta huanuco & 0 & 0 & 0 & 1 & 0 & 1 & 0 \\
Leptinus testaceus & 1 & 0 & 0 & 1 & 0 & 1 & 0 \\
Catopocerus sp. & 0 & 0 & 0 & 1 & 0 & 1 & 0 \\
\hline & & & & & & & \\
\hline & & 0 & 0
\end{tabular}




\section{Supporting Information}

Appendix S1. Strict consensus tree obtained in parsimony analyses with Baryodirina included in the data matrix. The resultant topologies of both equal and implied weigthing analyses were the same of that depicted in the Figs 25 and 26, respectively. Therefore, only the Ptomaphagini clade is showed. 

CAPÍTULO 4 

Show me your tenent setae and I tell you who you are - Telling the story of a neglected character complex with phylogenetic signals using Leiodidae (Coleoptera) as a case study

Pedro Gnaspini ${ }^{1}$, Caio Antunes-Carvalho ${ }^{1}$, Alfred F. Newton ${ }^{2}$, and Richard A. B. Leschen ${ }^{3}$

${ }^{1}$ Departamento de Zoologia, Instituto de Biociências, Universidade de São Paulo (IBUSP), São Paulo, SP, Brazil.

${ }^{2}$ Zoology Department/Insect Division, Field Museum of Natural History (FMNH), Chicago, IL, USA.

${ }^{3}$ Landcare Research, New Zealand Arthropod Collection (NZAC), Auckland, AK, New Zealand.

Correspondence: Pedro Gnaspini, Departamento de Zoologia, Instituto de Biociências, Universidade de São Paulo, Rua do Matão, Travessa 14, no. 101, 05508-090, São Paulo, SP, Brazil. E-mail: gnaspini@ib.usp.br 



\begin{abstract}
The tarsal setae in 97 species of Leiodidae and eight outgroups were examined using SEM imaging and dissections. Modified adhesive setae present in males are referred to as "male tenent setae" (MTS). In most cases, dilated tarsomeres were associated with MTS, which were always present on the protarsi and sometimes the mesotarsi. MTS are reported for the first time on the mesotarsi of Leptodirini and on the metatarsus in two genera of Sogdini. Contrary to reports in the literature, the reduction in the number of the MTS bearing mesotarsomeres is considered a derived condition. Both sexes of Leptinus (Platypsyllinae) have modified setae (referred to as tenent setae in the literature), probably related to their specialised association with mammals, and a patch of MTS was recognized for the first time among those modified setae among males. Four main types of MTS are recognised: (1) a plesiomorphic discoidal type that has a shaft with a round cross-section and maintains a similar diameter throughout its length until forming the expanded discoidal terminal plate; (2) a minidiscoidal type, similar to discoidal but with a relatively small terminal plate, found in Cholevinae; (3) a conical type, present in Leiodinae (excluding Estadiini) where the shaft increases in diameter until forming the terminal plate; and (4) a spatulate type, where an even wider terminal plate has a lateral projection, derived from the conical form and synapomorphic for the leiodine tribes Pseudoliodini, Scotocryptini, and possibly Agathidiini.
\end{abstract}





\section{Introduction}

Attachment structures on the tarsi of flies, beetles and the feet of other animal groups have been studied for centuries and the similarity in the structure of the adhesive devices of phylogenetically distant animals such as insects, spiders, and geckos has caught the attention of biologists, physists, and chemists (Wang et al., 2016 and references therein). These studies focus mainly on the structure of the adhesive devices and the physics, chemistry, and physiology of the attachment (e.g. Ishii, 1987; Walker, 1993; Gorb et al., 2001; Betz, 2003; Niederegger \& Gorb, 2003; Gorb, 2008; Gorb et al., 2008; Parsaiyan et al., 2009; Grohmann et al., 2014; Peisker et al., 2014) and have been the focus of biomimetic studies and applications. Attachment may be supplemented with various kinds of fluids (wet adhesion) or not (dry adhesion) (e.g. Gorb, 2008) and two main types of attachment mechanisms have been recognized (e.g. Gorb \& Beutel, 2001; Gorb, 2008): 1) setose (hairy) surfaces and 2) smooth flexible pads. The former is very common on insect tarsi, and it seems to have evolved independently in several lineages (e.g. Gorb \& Beutel, 2001). Gorb (1998) recognized two types of setae on the pulvillus of flies: spoon-like seta, with a strongly compressed tip, and seta terminating in an ellipsoid plate referred to as "tennet hair" or "adhesive seta" in the literature.

Most tenent setae are widened or bear apical discs (e.g. Stork, 1980; Gorb et al., 2002; Niederegger et al., 2002). The tips of tenent setae are frequently bent towards the shaft (e.g. Bauchhenss \& Renner, 1977) and are relatively soft structures (e.g. Niederegger et al., 2002; Gorb, 2008) which may conform to smooth surfaces. Eimüller et al. (2008) demonstrated that the spatular tip of tenent setae of a beetle flex, widening and thinning during attachment.

Few studies specifically examine the phylogenetic distribution of attachment devices (e.g. Haas \& Gorb, 2004 for Dermaptera; and Stork, 1980 provides an extensive comparative study on the tenent setae of selected groups of Coleoptera). In addition, although most studies focus on attachment devices relating to locomotion or even prey capture (as in Betz \& Mumm, 2001), only a few focus on sexual dimorphism (e.g. Voigt et al., 2008; Liu \& Liang, 2013) and rarely in a phylogenetic context (as in Pohl \& Beutel, 2004; Bergsten \& Miller, 2007), despite the dimorphism being well recorded in the taxonomic literature. Modified adhesive setae present only in males (from here on referred to as male tenent setae - MTS) would help them to attach to the female integument during mating. We focus our comparative study on one family of beetles to ascertain the distribution and potential phylogenetic signal of these modified setae.

The beetle family Leiodidae includes over 4,100 described species with very diverse feeding habits and a worldwide distribution (Newton, 1998, 2016). Leiodid specialists have long known that males can be distinguished from females because the former would have expanded tarsomeres bearing $M T S$ on the protarsi and sometimes the mesotarsi. These features have been used for family-group 
classifications (e.g. Jeannel, 1936; Newton, 1998; and included in taxonomic descriptions) and are present in other staphyliniforms and many other groups of beetles (e.g. Stork, 1980). Among leiodids, there are only some cases where these structures are illustrated (e.g. Leschen, 2000; Moldovan et al., 2007; Perreau \& Růžička, 2007), and frequently not in detail (as in Wheeler, 1979; Roubik \& Wheeler, 1982; Peck, 1998; Wheeler \& Miller, 2005; Peck \& Cook, 2011; Perreau \& Perkovsky, 2015 [of an amber fossil]). As these and other studies indicate, the variation of MTS offers a chance to explore a remarkable diversity of attachment structures within a single beetle family.

We broadened the survey of attachment structures in leiodids (started with Antunes-Carvalho \& Gnaspini, 2016 on the pretarsus of Cholevinae) and analyzed representatives of as many genera of non-cholevines as possible. As far as we know, this is the first time that it is demonstrated that the arrangement and shape of MTS, which is quite variable, may help corroborate the monophyly of some family-group taxa.

\section{Material and Methods}

\section{Taxa studied}

We analysed 97 species of Leiodidae (Table 1), that included representatives of all tribes, and eight outgroup taxa, including five Agyrtidae, the sister-taxon to Leiodidae (e.g. Newton, 1998; McKenna et al., 2015). The suprageneric classification of Leiodidae is based on Newton (1998), Perreau (2000), and Bouchard et al. (2011).

A large part of the non-cholevines studied was in the New Zealand Arthropod Collection (NZAC - Landcare Research, Auckland, New Zealand), and part was loaned to PG from the Coleoptera Collection from the Field Museum of Natural History (FMNH - Chicago, U.S.A.). Those specimens are identified with purple labels "Pedro". Remaining cholevines (referred to in Antunes-Carvalho \& Gnaspini, 2016) were donated or loaned to PG.

\section{Scanning Electron Microscopy (SEM)}

Typically, the tarsus from each of the three legs of the left side of each adult specimen was examined using SEM. Detached legs were mounted on stubs using carbon adhesive pads. The material was sputter-coated with gold and examined either in a JEOL NeoScope JCM-5000 (from NZAC) or in a ZEISS DSM 940 (from IBUSP) scanning electron microscope.

\section{Numerical analysis}

We measured the length of the shaft and its diameter (both at the base and at its tip, at the insertion of the terminal plate), and the diameter of the terminal plate to ascertain patterns of MTS 
among species. Ratio between length and diameter of the shaft, between diameter of the shaft at the tip and at the base, and between the diameter of the terminal plate and the base of the shaft was also measured.

\section{Literature review}

To appreciate the range of variation within each tribe, we searched the taxonomic literature to supplement our direct observations on the number of expanded tarsomeres on the male protarsi and mesotarsi (Table 4 ). We analyzed $\sim 180$ papers with a diversified sampling of taxa, but we did not make an exhaustive search for all described species or genera of the family.

\section{Results}

The SEM micrographs obtained in this study are in Figs. 1-23, following the taxonomic sequence (e.g. as in Newton, 1998). We identified four characters with four states each (Table 2). Specific variation will be treated in the Discussion.

\section{Presence of male tenent setae on the male protarsi (Char 1) and male mesotarsi (Char 2)}

First, instead of observing the presence of expanded tarsomeres, as is commonly referred to in the taxonomic literature of the group, we decided to code the presence of tarsomeres with MTS. Tarsomere shape is variable, especially when the penultimate tarsomere may be only slightly expanded. Because of that, it is common to observe in the literature that some authors count the penultimate tarsomere as expanded while other authors do not count the same shaped tarsomere as expanded.

Second, instead of coding the number of tarsomeres with MTS (as is common in the literature), we decided to use the number of remaining distal tarsomeres that do not bear MTS. The explanation for this decision is the fact that several taxa show a reduction in the number of tarsomeres, and this reduction may be different between each of the three pairs of legs. In our view, a 5-segmented tarsus with the first three tarsomeres bearing MTS (i.e., the two distal tarsomeres lacking MTS) is homologous to a 3-segmented tarsus with only the first tarsomere bearing MTS.

Third, although we understand that to have only the last tarsomere or the last two tarsomeres without MTS may be considered different states, we decided to code them as a single state here, because we noticed, from the literature, that different species from the same genus (or from the same subtribe/tribe) may show this kind of variation; and, as mentioned before, the penultimate tarsomere may be counted as expanded or not depending on an author's interpretation. In addition, we understand that this type of coding would not interfere in our analysis and discussion. 
We used the following states (ordered):

$0=1-2$ tarsomeres without MTS (e.g., Figs. 1A, 2B-C, 6E-F)

$1=3$ tarsomeres without MTS (e.g., Figs. 1B,R)

$2=4$ tarsomeres without MTS (e.g., Figs. 2H, 6G, 10K)

$3=$ all tarsomeres without MTS (e.g., Fig. 4D)

Shape of the male tenent setae (Char 3)

Four main types of MTS are recognised with the additional help of a numerical analysis (see Materials and Methods and Table 3): (1) discoidal, (2) minidiscoidal, (3) conical, and (4) spatulate types.

The plesiomorphic discoidal type (Figs. 13H, 14D) has a shaft with a round cross-section and maintains a similar diameter throughout its length until forming the expanded discoidal terminal plate. The medial region of the shaft is frequently slightly narrower than the base, and the tip diameter is generally wider (1.3 to 2.0 times) than the shaft base. This type is widespread within Leiodidae and appears in all representatives of the Agyrtidae (typically in Apteroloma, Pteroloma, and Zeanecrophilus) and also in the staphylinid Philonthus (Fig. 23C-E,G).

The terminal plate occasionally appears to bear convexly bent margins (or "rim", according to Stork, 1980; e.g. Fig. 13F,I). The tip of the shaft is connected to the central region of the terminal plate. In some cases, it is possible to observe that this attachment is excentric (e.g. Fig. 14A,D).

In most of the cases, the shaft leads straight towards the terminal plate, whose surface lays subparallel (or at most in an angle smaller than $45^{\circ}$ ) to the ventral surface of the tarsomere. In some cases, however, the shaft has an S-shape double curvature just before reaching the apex (as in Dasypelates - Fig. 13G, and in Agyrtodes ovatus - Fig. 13B; but not in Agyrtodes monticola - Fig. 13A). In these cases the terminal plate is frequently concavely curved and its surface is placed subperpendicularly (or at least in an angle greater than $45^{\circ}$ ) to the ventral surface of the tarsomere (Fig. 13B).

The minidiscoidal type (Fig. 20B-F) is similar to discoidal but with a relatively small terminal plate (1.2 to 2.4 times the diameter of the shaft base whereas the discoidal type ranges from 2.5 to 3.6 times - Table 3$)$. In addition, the tip of the shaft is narrower ( 0.5 to 1.3 times the diameter at the base) and the shaft continuously narrows from base to tip, with no medial constriction. It is common to observe terminal plates clumped together (e.g. Figs. 20A-B,L). This is the main type observed among Cholevinae. 
In the conical type (Figs. 16B,I, 17D), the shaft is generally short (7.0 to 8.5 times as long as its diameter at the base) and it increases in diameter distally (2.2 to 3.5 times) until forming the terminal plate. It is present in Leiodinae (excluding Estadiini) and in the agyrtodine Agyrtolasia.

The spatulate type (Fig. 18E-G) is considered to be derived from the conical type and has an even wider terminal plate with a frequently elongate acuminate projection at one side. The shaft does not continuously grow, but widens near the tip. It is still shorter (3.5 to 7.0 times as long as its diameter at the base) and bears a very wide terminal plate (5.4 to 11.0 times as wide as the diameter of the shaft base). The lateral projection may be short and thin (as in Anisotoma [Fig. 17C], which is the only Agathidiini with spatulate $M T S$ - the others mostly bear a conical type) or long and tape-shaped, as seems to be the rule amongst Pseudoliodini and Scotocrytpini (e.g. Fig. 18F-G,I-J).

We hypothesize that, from the plesiomorphic discoidal state, there is a branching transformation series: in one group, the minidiscoidal type, and in the other group the conical type followed by the spatulate type. Therefore, we use the following states (a branching transformation series, ordered: $3 \leftarrow 0 \rightarrow 1 \rightarrow 2$ ):

$0=$ discoidal (e.g., Figs. 13H, 14D)

$1=$ conical (e.g., Fig. 16B,I, 17D)

$2=$ spatulate (e.g., Fig. 18E-G)

$3=$ minidiscoidal (e.g., Fig. 20B-F)

In some cases we had difficulties to precisely define the state for the shape of the setae we were observing, and our coding is considered tentative. We also found some cases which do not fit the classification described above (Zearagytodes, Catopsolius, Glacicavicola, Platypsyllus, Anthroherpon, Leptomeson, Boldoria, and the histerid Gnathoncus). They are coded as “?” in Table 2, and are addressed in the Discussion. A generalized transformation series for the MTS is depicted in Fig. 24.

\section{Arrangement of male tenent setae on the tarsomeres (Char 4)}

The number of longitudinal rows of MTS varies, apparently not strictly related to the width or shape of the tarsomere or the shape of the MTS. The number of rows coded (as in Fig. 6E, numbers) is based on the protarsi only, because the mesotarsi often bear a smaller number of MTS or frequently lack them at all. Since the number of rows may increase from the base towards the half of the tarsomere, and may decrease towards the apex, we counted the number of rows at the middle of the first tarsomere (which tended to be the largest one, bearing a large number of setae). We used the following states (ordered):

$0=$ more than 12 longitudinal rows (e.g., Figs. 1A, 9A, 10D) 
$1=8-12$ longitudinal rows (e.g., Figs. 1D, 5E, 6E)

$2=4-6$ longitudinal rows (e.g., Figs. 1C, 4E, 4G)

$3=2-3$ longitudinal rows (e.g., Figs. 5C, 6I, 7J). Actually, all taxa in this group bear only two rows of MTS except for Zelodes, with three rows.

\section{Discussion}

Terminology

According to Wigglesworth (1987), the term "tenent hair" was introduced by West (1862) for the trumpet-like structures on the pulvilli of flies. Its etymology relates to its function as an attachment device. However, the term "tenent hair" is also used in the literature for other types of setae with a spatulate apex, even without an attachment function and dorsally positioned, as, for instance, among Collembola (e.g. Christiansen, 1965; Christiansen \& Culver, 1987), or placed elsewhere than ventrally on the tarsus, as on the tibia of heteropterans (e.g. Wang \& Liang, 2015), or with different shapes, as in Araneae (e.g. Hill, 1977).

In the taxonomic literature of leiodid beetles (and all other groups having them), the special setae, generally with an expanded apex, ventrally placed on the expanded tarsomeres of males are referred to variously as "tenent setae" (e.g. Newton, 1998; Peck, 1998 [as "tenant"]; Leschen, 2000; Peck \& Cook, 2002; Salgado, 2005a; Seago, 2009; Seago \& Leschen, 2011; Seago et al., 2015), “apically-expanded setae" (e.g. Peck, 2003), “adhesive setae” (e.g. Newton, 1998; Salgado \& Fresneda, 2003; Miller \& Wheeler, 2004), "spatulate adhesive setae” (Wheeler, 1979); "spatulate setae” (e.g. Seago \& Wheeler, 2004; Miller \& Wheeler, 2005; Wheeler \& Miller, 2005; Peck \& Cook, 2014), "setae with adhesive pads" (e.g. Moldovan et al., 2007), "adhesive phanerae" (e.g. Perreau \& Růžička, 2007), or "phanerae (apically widened setae)” (e.g. Peck \& Cook, 2011). Hatch (1933), Fall (1937), and Peck \& Cook (2007) refer to the pro- and mesotarsi of some males as "dilated and spongy pubescent beneath".

Therefore, taking into account that:

a) "tenent setae", as an attachment device, are commonly found in insects, where they serve a general attachment function (for instance to walk on smooth surfaces), but the special setae here studied are found only (or, at least, mostly, but see discussion about sexual dimorphism) in males and probably have a specific function during mating (allowing the male to attach himself to the female body during sperm transfer);

b) the term "tenent hairs" is used in the literature for setae with the same shape but without the specific attachment function as those placed in ventral tarsal pads, as discussed above; and 
c) although "tenent hairs" is used in several cases in the literature on attachment structures, especially in older references, "tenent setae" is widespread in the taxonomic literature on Leiodidae, amongst several different terms, as discussed above,

we decided to adopt here the term "male tenent setae" (here abbreviated "MTS"), adding the adjective "male" to the commonly used term "tenent setae" in order to avoid confusion with other terms used in the literature and specify that we are analyzing sexually dimorphic structures present ventrally on male tarsomeres. We followed the reasoning of Stork (1980), who used "male setae", but we understand the need to reinforce the "tenent seta" nature of such setae. However, we are also aware that MTS may occasionally occur among females (as is here the case of Colon).

\section{Number of pro- and mesotarsomeres bearing male tenent setae}

In all cases examined, MTS were present on the male protarsi (Table 2). We conclude that this is the rule in Leiodidae (and other Staphylinoidea and many Coleoptera). With respect to the literature survey (Table 4), there are several cases where the absence of expanded protarsomeres is recorded among males, but this does not necessarily refer to the absence of MTS. For example, slender protarsi appear in several Leiodidae groups, and are common in Leptodirini (probably because of the slender habitus associated with subterranean habits), and they do bear MTS (e.g. Scotocryptus, Peck 2003; Agyrtodes, Seago, 2009; and Zeagyrtes, Glacicavicola, Gelae, Anthroherpon, Leptomeson, and Aphaobius, this study; Remyella has slender tarsi, but, since all setae are broken, we were not able to check for the distribution of MTS). They also are a diagnostic feature of Proptomaphaginus among Ptomaphagini (e.g. Peck, 1973). We therefore understand that these cases where no expanded protarsi were recorded in males in the literature should be checked for the presence of MTS.

With respect to the mesotarsi, we note more variation. Some groups have expanded tarsomeres with MTS (e.g. Leiodini, Sogdini, Agathidiini, and Scotocryptini) while others lack MTS and expanded tarsomeres altogether (as in most Pseudoliodini and the cholevine Ptomaphagini and Cholevina, with some exceptions recorded, as discussed by Jeannel, 1936 and Newton, 1998, for instance, and the Leptodirini - but see the remark as follows). When expanded, the mesotarsomeres of non-cholevines are symmetrically expanded whereas those of cholevines (except for the Leptodirini) are asymmetrical and the first mesotarsomere is frequently elongate.

Because distinguishing between the presence of MTS and width of tarsomeres has not been done, relying on literature to discriminate states is difficult in Leptodirini. For instance, Giachino et al. (2011) state and illustrate that species of Leptomeson have undilated protarsi among males (which is indeed true), and yet we examined MTS on three basal male protarsomeres. Furthermore, the Leptodirini lack expanded male mesotarsomeres (e.g., Jeannel, 1936; Newton, 1998), and, therefore, 
most (if not all) descriptions of leptodirines do not even mention this character. We detected MTS on the first (unexpanded) mesotarsomere of Platycholeus (Platycholeina, considered a basal group of Leptodirini - see, e.g., Fresneda et al., 2011) and Speoplanes (Leptodirina) (Fig. 10J,N), but not in the other leptodirines studied. This was a surprising observation, since the Leptodirini are a very diverse and well known group, and, as far as we know, this was not formally recorded before. However, for instance, Perriniella (Pholeuina) also has MTS on the first mesotarsomere based on Fig. 11 in Perreau $\&$ Tronquet (2002). Therefore, leptodirines deserve further study.

Although the genus Dissochaetus has been traditionally stated to lack expanded male mesotarsi (e.g., Jeannel, 1936), Hatch (1933) and Salgado (2006b) note that males of Dissochaetus arizonensis Hatch and D. machupicchuensis Salgado, respectively, have the first mesotarsomere slightly expanded ("strongly pubescent beneath" in the first species), which deserves a further examination.

In the taxonomic literature (e.g., Jeannel, 1936; Newton, 1998, and many others) the presence of expanded mesotarsomeres is treated as a derived condition of some leiodid groups (as, for instance, among Catopina and several genera within Eunemadina). For example, Baranowski (1993:13) treats the expanded pro- and mesotarsi as a "modification". In our view, however, this is a mistaken interpretation that has been maintained in the literature, and this scenario should be reversed. Considering that several non-cholevine leiodids bear expanded tarsomeres on both pro- and mesotarsi, and that this pattern also occurs in the outgroups, such as the Agyrtidae (in which expanded male proand mesotarsi is the rule) and even Staphylinidae, we may interprete that the presence of expanded pro- and mesotarsomere is the plesiomorphic state in Leiodidae. In these outgroups, the four basal tarsomeres of both pro- and mesotarsi are generally expanded. Therefore, the absence of expanded mesotarsomeres should be considered an apomorphic homoplastic state shared by several lineages within Leiodidae.

In some cases where the male mesotarsomeres are not expanded or bear MTS, we observed an additional kind of sexual dimorphism, as in some Agyrtodini. Although it is common to observe a ventral row of spines at both lateral margins on mid- and posterior legs of both males and females in several groups of leiodids, the ones on the first two male mesotarsomeres of Zeagyrtoma are longer than usual (Fig. 12B) and those on male Zearagytodes are slightly thicker than usual and with a second row at the base of the first mesotarsomere (Fig. 12C). Cholevomorpha is remarkably different, with a conspicuous row of very thick and blunt spines on the first mesotarsomere (Fig. 12A). The other Agyrtodini studied have the regular pattern of setae on both meso- and metatarsus. A series of thick, pointed spines at both lateral sides on the mesotarsus was observed in Dissochaetus (Cholevinae, Eunemadina), as in Fig. 12D-E, but not in the other Eunemadina with slender mesotarsi (Pseudonemadus). 
Generally, the width and number of MTS of expanded tarsomeres progressively reduce distally, and the distal one bears the claws and is not expanded, but Dietta is an exception. In the two species we examined, the first protarsomere is almost glabrous, and bears only a few MTS (only one, in one species) at the apical margin. In addition, an undescribed species where the male tarsal formula is 54-4 (but 5-5-5 is typical of Estadiini), also differs from the other species by having mesotarsi lacking MTS (compare Fig. 4C-D to Fig. 4A-B). Agyrtodes (Agyrtodini) is another exception, where A. ovatus shows MTS on the mesotarsus whereas A. monticola does not.

Another remarkable exception is that we detected MTS on all three legs for two sogdine genera (Metahydnobius and Triarthron - Figs. 4K,N), but not other members of the tribe (Hydnobius and Isocolon). We examined only females of Hydnodiaetus and Platyhydnobius, and the remaining members of the tribe should be examined to check if this character is a potential synapomorphy. This feature was also recorded by Salgado (2011a) for males of Falkonemadus (Cholevinae), but this may be erroneous (see his Fig. 11).

A third unexpected observation is the presence of modified setae on the distal mesotarsomere (but not in the basal ones) in Leptomeson. They are similar to the protarsal MTS of the Anthroherponina (Anthroherpon and also Leptomeson, Fig. 22B-C - see next section).

\section{Shape of the male tenent setae}

We observed four main types of MTS and additional variations infrenquently observed in our sample. The discoidal type is similar to the pattern called "disco-setae" by e.g. Stork (1980), "type 7 setae" by e.g. Betz (2003), "spatula-tipped setae" by e.g. Sukontason et al. (2006) and Wang et al. (2016), "adhesive setae with discoidal tips" by e.g. Geiselhardt et al. (2010), or "discoidal setae" by e.g. Bian et al. (2014). The discoidal MTS is composed of a "shaft" and a "terminal plate", following terminology by e.g. Eimüller et al. (2008), Liu \& Liang (2013), and Bian et al. (2014) (also called “plate” by e.g. Stork, 1980, "terminal element” by e.g. Haas \& Gorb, 2004, Gorb et al., 2008, and Voigt et al., 2008, "endplate" by e.g. Niederegger et al., 2002 and Moon et al., 2013, or "apical plate" by e.g. Wang \& Liang, 2015).

Our discoidal type seems to be widespread among Coleoptera and agrees with the type recorded by Stork (1980) for Staphylinidae. However, we did not observe setules, which seem to be typical on the dorsal surface of the setae among Staphylinidae, and this deserves further investigation. Wide setae (similar to those here named conical type) were only recorded in some Carabidae by Stork (1980, named "squamo-setae"), also in two rows and frequently overlapping each other, as we recorded for Sogdini and especially for Scotocryptini (e.g. Fig. 7E,L-M). In Carabidae, very wide setae (as those 
here named spatulate) were also recorded, but never with an elongate projection (as they do in our spatulate type).

When we compare our data to the few figures available in the Leiodidae literature (e.g. in Wheeler, 1979: Figs. 16, 18, 21, for Creagrophorus; Peck, 1998: Fig. 2, for Colenis; Leschen, 2000: Fig. 23, for Zelodes; Wheeler \& Miller, 2005: Fig. 30, for Agathidium; Moldovan et al., 2007: Fig. 4e, for Pholeoun; Perreau \& Perkovsky, 2015: Figs. 5-6, for a fossil Catops), our results agree with the morphologies observed by other authors.

Catopocerini was an exception. In the species of Catopocerus studied by Perreau \& Růžička (2007: Figs. 27, 28), the mesotarsi lack MTS, which differs from the two species here studied. Variation was also observed regarding the type of MTS: the species of Catopocerus studied here seems to bear a conical type (Fig. 15A), whereas the species of Pinodytes seems to bear a spatulate type with a short projection (Fig. 3C-D, unfortunately, a very dirty specimen); and the species studied by Perreau \& Růžička (2007: Figs. 27) bears a spatulate type with a very long projection, resembling the pattern which seems to be typical of Pseudoliodini+Scotocryptini. Although not given in SEM details, the figures from Peck \& Cook (2011: e.g. Figs. 45-46), for Pinodytes, also show conical and/or spatulate patterns. This would reinforce the idea that Catopocerini and Leiodinae are closely related taxa (e.g. Newton, 1998), but may indicate that the first is nested within the latter, which deserves further investigation. Moreover, the genus Perkovskius, tentatively assigned by Perreau \& Růžička (2007) to Catopocerinae, bears a conical MTS type (Perreau \& Růžička, 2007: Figs. 23, 24, 26) and a larger number of MTS than the Catopocerini here studied, and its placement also deserves further analysis.

Despite the type of MTS, it is common to observe that the basal most MTS are generally shorter than the remaining MTS, but in Creagrophorus (Scotocryptyni) they differ. In this genus, they expand in length and width from the basal most towards the distal most (Fig. 7L-M) and the group of MTS is shaped as an inverted triangle (with its apex facing the base of the tarsus). This seems to be unique, though Stork (1980: Figs. 9E, 10D, 76) recorded a similar case of increase in setal size with overlap for a group of carabids, but not with strongly overlapping MTS.

In some cases (e.g. Paragyrtodes, Sphaeropelatops, Cyrtoplastus, Parabystus, Parapaulipalpina - Figs. 13J, 14K, 17D, 18K, 21C, arrows), the terminal plate bears a notch at the base, resembling those where an opening (to deliver adhesive secretion) was observed in other insects (e.g. Gorb, 1998: Fig. 2a). It is still premature to state if an opening is present in the taxa studied here. Geiselhardt et al. (2010) show that an internal canal can be seen on broken setae of a chrysomelid beetle. In the species we studied where broken setae were observed (e.g. Remyella and Aphaobius Fig. 22D,I), they were not hollow, but the atypical setae of Speoplanes are (Fig. 22E). Stork (1980) observed similar intuckings beneath the setal plate on the setae recorded among carabids. That author 
hypothesized that the intuckings would increase the flexibility of the setal tip, working as a hinge between the plate and the shaft. This mechanism would help preventing setal removal during sudden movements.

Some species have MTS that differ from the usual morphologies described above. The tarsi of the histerid Gnathoncus bear a single row of very long, leaf-shaped tenent setae (Fig. 11M), which are not comparable to the ones observed in the other Staphylinoidea. Among Leiodidae, Zearagytodes, differing from the other agyrtodines studied, shows a large number of atypical setae with an elongate tip, without a terminal plate (Figs. 1T, 13N), which we recognize as MTS because the tarsomeres are typically expanded.

The legs of Catopsolius (Neopelatopini) are densely covered by long setae (Fig. 2K), making it difficult to observe the presence of MTS, and even of expanded tarsomeres, under the stereomicroscope. Since we prepared specimens of both sexes, we could recognize the presence of atypical MTS (Fig. 14G), which resemble "type 9" setae of Betz (2003). They are typically spatulate, and do not bear a discoidal terminal plate. "Type 9" MTS were also here detected on the non-expanded protarsi of the Anthroherponina leptodirines here studied (Anthroherpon and Leptomeson - Figs. 10C, 22B-C), but not on the remaining leptodirines. Since there are some differences between the MTS observed on these two taxa, it is premature to make any phylogenetic conclusion. The apical most tarsomeres of most Agyrtidae are also densely covered by long setae (Fig. 11C-G), but the basal most tarsomeres are well expanded and typical discoidal MTS are observed.

\section{Arrangement and number of male tenent setae on the protarsi}

Analyzing the possible relationship between type and arrangement of MTS (from Table 2), we notice that the MTS cover $8-12$ rows in $44 \%$ of the 32 genera with discoidal type (including the agyrtid and staphylinid outgroups), and they cover 4-6 rows in 31\%. Considering the minidiscoidal type, most Cholevinae ( $69 \%$ of 29 genera) fit the ">12 rows" pattern, and the rest fit the " $8-12$ rows" pattern, except for Aphaobius, which fits the "4-6 rows" pattern. In the case of the conical type, $60 \%$ of the 10 genera would fit the "4-6 rows" pattern and the others fit the "2-3 rows" pattern, except for Amphicyllis, which fits the "8-12 rows" pattern. All 14 genera with spatulate type fit the "2-3 rows" pattern, except for Anisotoma, which fits the "8-12 rows" pattern, and which is the only non Pseudoliodini+Scotocryptini genus with this type of MTS.

This pattern is more or less reflected when the total number of setae is counted and related to the number of rows observed. In the genera with $>12$ rows of discoidal and minidiscoidal types of MTS, the numbers range from 200 (e.g. Cholevomorpha and Eupelates) to more than 1000 setae (e.g. Eucatops). In turn, in the genera with 8-12 rows of the same types of MTS, these numbers fall to 100- 
150. We should note that the same numbers are found on Amphicyllis (conical type) and Anisotoma (spatulate type). Regardless of the type of MTS, the genera with 4-6 rows of MTS have less than 60, typically from 20 to 35 MTS, except for Triarthron (with 100 MTS). Finally, the genera with 2-3 rows of MTS typically have less than 20 MTS rows, except for the pseudoliodine Zelodes and the scotocryptine Parabystus, both with 32-33 MTS. The smallest number recorded was 8 MTS in the agathidiini Decuria and in the pseudoliodine Colenisia. It should be noted that, whereas the MTS of Pseudoliodini (which have five protarsomeres, except for Zelodes, with four protarsomeres) cover the first three protarsomeres, the same number of MTS is restricted to the first, expanded protarsomere among Scotocryptini (with tarsal formula 3-3-3).

\section{Tenent setae of Coloninae and Platypsyllinae}

The literature states that both males and females of Coloninae and Platypsyllinae have tenent setae. For instance, Newton (1998) lists for Platypsyllinae "pro- and mesotarsi of both sexes dilated and with adhesive setae" (p. 60) and "tarsi all 5-segmented, with tenent setae on 4 or all 5 segments of pro- and mesotarsi of both sexes" (p. 133). Newton (1998) also states for Coloninae "protarsi of both sexes dilated and with adhesive setae; mesotarsi of neither sexes dilated or with adhesive setae" (p. 60 ) and "tarsi all 5-segmented, anterior tarsi of both sexes usually dilated and with tenent setae" (p. 97). Therefore, Newton (1998) uses "adhesive setae" and "tenent setae" indistinctly to refer to the special setae of both sexes in Coloninae and Platypsyllinae or to the MTS of the remaining leiodids.

Except for Coloninae and Platypsyllinae, in all other cases where female tarsi were observed (Table 1, marked “\&F”), no tarsomere was expanded and no tenent seta (or any kind of special seta) was observed. In turn, in both Coloninae and Platypsyllinae, we could not be sure which sex has been analyzed when we did not observe the genitalia of the specimens. However, at least in the case of Leptinus, we can state that MTS do exist only among males. When we analyse the mesotarsus, we can observe it is covered with a dense layer of special, point-tiped setae (Fig. 8D). In turn, the protarsus is covered by both the point-tiped setae and typical discoidal type MTS, the later being restricted to the first two protarsomeres (Figs. 8C, 19B). Moreover, the mesotarsi seem to be narrower than the protarsi. We also analysed a female, where both pro- and mesotarsi were covered only with point-tiped setae (Fig. 8E). The same situation was observed in Chrysomelidae, where the ventral surface of both sexes is covered with tenent setae, but patches of "setae with discoidal terminal parts" can be recognize inside the surface covered by tenent setae only among males (e.g. Voigt et al., 2008).

Therefore, we here stress the need to use a different term (here we use "male tenent setae") to refer to the sexually dimorphic setae present only on male tarsomeres, to avoid confusion with other types of adhesive setae present on insect tarsi and related to other attachment functions (such as 
locomotion, or attachment to a host, as is the case of the Platypsyllinae). In the case of Platypsyllinae (at least in Leptinus), the diagnostic features should read "both sexes bear special adhesive setae on both pro- and mesotarsi, and males bear MTS on the protarsi only".

In the case of Leptinillus, the protarsi are much wider than the mesotarsi (Fig. 8A-B), but both are covered only with point-tiped tenent setae. This may indicate that the specimen studied was a female, but it was not dissected, since we were dealing with old, rare material.

In turn, Platypsyllus seems to be a completely different case. All five tarsomeres of both proand mesotarsi are covered with special thick setae, with a transversely undulate integument (Figs. 8FG, 19C-D). They seem to have a clavate shape, but it is possible to observe in lateral view that they are concave, spoon-shaped (Figs. 19C-D). We analyzed the legs of two specimens (one a male), with the same results. We can confirm that, although pro- and mesotarsi are expanded, there are no MTS. Furthermore, the special expanded setae would be related to the ectoparasitic behaviour of the species of this genus. Yet, we should note that the special setae of Platypsyllus differ largely from those of Leptinillus and Leptinus. Transverse ridges on the setae have only been recorded by Stork (1980) among males of the silphid Nicrophorus, but with a different pattern.

In the Coloninae, we dissected four specimens, one of them a female. In all the specimens examined we observed the four first protarsomeres to be expanded and covered with discoidal tenent setae. Therefore, in Coloninae, both sexes are not sexually dimorphic.

\section{Summary and phylogenetic implications}

While the variation in the shape and arrangement of MTS are of taxonomic significance (and should be included in taxonomic descriptions), we believe that they may also offer phylogenetic signal among Leiodidae, and in a future study we plan to code the variation observed here in a phylogenetic study of the family. In the present stage, some phylogenetic implications can already be discussed, as follows.

The minidiscoidal MTS seem to be typical of Cholevinae (with additional variation occurring in this diverse taxon), although recorded in other leiodids as well.

The conical MTS seem to be synapomorphic for Leiodinae (except for Estadiini), and may be included as a character for the recognition of this subfamily. And the additional increase in width (towards the spatulate type) seems to have occurred in the group Agathidiini + Pseudoliodini + Scotocryptini, which has been recognized as a probable phylogenetic unit by Newton (1998), and can be included as a diagnostic character for this group. In addition, the presence of the spatulate type in combination with a reduction in the number of rows with MTS seems to be synapomorphic for a group uniting Pseudoliodini and Scotocryptini, which, as far as we know, has not been proposed before. This 
distribution is congruent with the phylogenetic tree shown by McKenna et al. (2015). Moreover, within Leiodinae, Pseudoliodini may be characterized by the apomorphic absence of MTS on the mesotarsi, with a few exceptions. A further phylogenetic analysis of Leiodidae may help understand if this may be used, for the first time, as a synapomorphy for this tribe.

Although the monotypic ice-cave Glacicavicolini has been considered to be the sister taxon to Catopocerini and placed together in the subfamily Catopocerinae (e.g. Newton, 1998), they show different types of MTS. Glacicavicolini show the probable plesiomorphic discoidal type, whereas species in Catopocerini show the conical and/or spatulate type, which is typical of a group within Leiodinae, as previously discussed. Catopocerinae has been indeed considered to be the sister taxon to Leiodinae (e.g. Newton 1998), but our findings indicate that they (maybe without Glacicavicolini) may be actually nested within Leiodinae.

The presence of MTS on the metatarsus of Metahydnobius and Triarthron may be a unique synapomorphy that characterizes a clade within Sogdini. The analysis of additional genera of the tribe is welcome to verify the distribution of this feature and its probable recognition as a diagnostic character. Within Coleoptera, MTS have been recorded by Stork (1980) on the metatarsus of several (but not all) chrysomelids and in the coccinellid Coccinella (probably as an exception since the other genera of the family studied by that author have MTS only on pro- and mesotarsi).

Platypsyllinae is also a taxon which deserves attention, since the special setae present on the tarsi of Platypsyllus are completely different from those present in Leptinillus and Leptinus. However, its uniqueness characterizes an autapomorphic state that cannot be used for phylogenetic purposes.

The large and diverse Leptodirini have been traditionally recognized as lacking sexual modifications on the mesotarsi (e.g. Jeannel, 1936; Newton, 1998), but we observed the presence of MTS on the mesotarsi of two unrelated genera (Platycholeus and Speoplanes), although their mesotarsi are not expanded. Therefore, this feature should be analyzed in other representatives of the tribe more thoroughly. Meanwhile, the modified type in Anthroherponina (a potential basal clade of the Old World Leptodirini - see discussion in Antunes-Carvalho \& Gnaspini, 2016) is also a plausible synapomorphy for the subtribe.

We are presently working on a cladistic analysis using morphological data to access the phylogeny of the family Leiodidae. The data presently described and discussed will be included in the near future in a more complete matrix. Nevertheless, it seems to have shed some light on the somewhat still obscure view of the phylogenetic relationships within Leiodidae. We also understand that our findings are relevant from a taxonomic point of view since they clearly show that the MTS are useful tools to recognise taxa at various supraspecific levels. 


\section{Acknowledgements}

PG thanks Landcare Research for hosting him during the development of part of the present study, and for the access to the NZAC, where a large part of the presently studied material is deposited. We also thank the following researchers for the loan/donation of additional studied material: Andrea Colla (Museo Cívico di Scienze Naturali, Trieste, Italy), Cristiano Lopes Andrade (Universidade Federal de Viçosa, Viçosa, Brazil), Crystal Maier (Field Museum of Natural History, Chicago, U.S.A.), Jan Růžička (Czech University of Life Sciences, Praha, Czech Republic), Stefano Zoia (Museo Civico di Storia Naturale di Milano, Milano, Italy) and Stewart Peck (Carleton University, Ottawa, Canada). The latter is also thanked for comments on a first draft. This study was supported by grants from FAPESP (Fundação de Amparo à Pesquisa do Estado de São Paulo, Brazil) \#2014/22898-1 and 2013/06314-7 (to PG), and 2012/19002-0 (to CAC). RABL was funded in part by core funding for Crown Research Institute from the Ministry of Business, Innovation and Employment's Science and Innovation Group (New Zealand). We thank B. Rhode for the access and help in the use of the electron microscopy facilities from Landcare Research, and Dr. Alberto A.G.F.C. Ribeiro and Márcio V. Cruz for the access and help in the use of the electron microscopy facilities from the Electronic Microscopic Laboratory of IBUSP. The authors declare that they have no conflict of interest.

\section{References}

Alonso, C. \& Lefebvre, V. (2012) Contribution à la connaissance des Leptodirini: le genre Cytodromus Abeille, 1876 (Coleoptera : Leiodidae, Cholevinae). R.A.R.E., 21, 92-101.

Alonso, C. \& Lefebvre, V. (2013) Contribution à la connaissance des Leptodirini: le genre Speophyes Jeannel, 1910 (Coleoptera : Leiodidae, Cholevinae). R.A.R.E., 22, 69-74.

Angelini, F. \& Švec, Z. (1995) New species and records of Leiodinae from China (Coleoptera: Leiodidae). Linzer Biologische Beiträge, 27, 507-523.

Antunes-Carvalho, C. \& Gnaspini, P. (2016) Pretarsus and distal margin of the terminal tarsomere as an unexplored character system for higher-level classification in Cholevinae (Coleoptera, Leiodidae). Systematic Entomology, 41, 392-415. DOI 10.1111/syen.12161.

Baranowski, R. (1993) Revision of the genus Leiodes Latreille of North and Central America (Coleoptera: Leiodidae). Entomologica Scandinavica, Suppl. 41, 1-149.

Bauchhenss, E. \& Renner, M. (1977) Pulvillus of Calliphora erythrocephala Meig. (Diptera: Calliphoridae). International Journal of Insect Morphology \& Embryology, 6, 225-227.

Belles, X. (1973) Un nuevo Bathysciinae del macizo de Carraf (Barcelona). Miscelánea Zoológica, 3 , 45-49.

Bergsten, J. \& Miller, K.B. (2007) Phylogeny of diving beetles reveals a coevolutionary arms race between the sexes. PLoS ONE, 2, e522. DOI 10.1371/journal.pone.0000522.

Betz, O. (2003) Structure of the tarsi in some Stenus species (Coleoptera, Staphylinidae): External morphology, ultrastructure, and tarsal secretion. Journal of Morphology, 255, 24-43.

Betz, O. \& Mumm, R. (2001) The predatory legs of Philonthus marginatus (Coleoptera, Staphylinidae): functional morphology and tarsal structures. Arthropod Structure and Development, 30, 77-97. 
Bian, X., Liu, Z. \& Liang, A.-P. (2014) Ultrastructural morphology of tarsus of Aspidomorpha dorsata (F.) (Coleoptera: Hispidae). Journal of Entomological Science, 49, 78-86. DOI 10.18474/0749-8004-49.1.78.

Blanco-Villero, J.M. \& Sáez-Bolaño, J.A. (2014) New species of the genus Sogda Lopatin, 1961 from the Iberian Peninsula (Coleoptera, Leiodidae, Leiodinae). Graellsia, 70, e010. DOI 10.3989/graellsia.2014.v70.112.

Blas, M. \& Borges, P.A.V. (1999) A new species of Catops Paykull, 1798 (Coleoptera: Cholevidae) from the Azores with remarks on the Macaronesian fauna. Elytron, 13, 173-184.

Bognolo, M. \& Kofler, B. (2001) Pretneria metkae mirae ssp. n. (Coleoptera: Cholevidae) from Mount Prisojnik, Slovenia. Acta entomologica, 9, 113-118.

Bouchard, P., Bousquet, Y., Davies, A.E., Alonso-Zarazaga, M.A., Lawrence, J.F., Lyal, C.H.C., Newton, A.F., Reid, C.A.M., Schmitt, M., Ślipiński, S.A. \& Smith, A.B.T. (2011) Familygroup names in Coleoptera (Insecta). Zookeys, 88, 1-972. DOI 10.3897/zookeys.88.807.

Casale, A., Giachino, P.M. \& Jalžić, B. (2000) Croatodirus (nov. gen.) bozicevici n. sp., an enigmatic new leptodirine beetle from Croatia (Coleoptera, Cholevidae). Natura Croatica, 9, 83-92.

Casale, A., Giachino, P.M. \& Jalžić, B. (2004) Three new species and one new genus of ultraspecialized cave dwelling Leptodirinae from Croatia (Coleoptera, Cholevidae). Natura Croatica, 13, 301-317.

Casale, A., Giachino, P.M. \& Vailati, D. (2013) Tre nuove specie di Coleotteri sotterranei di Grecia (Coleoptera: Carabidae e Cholevidae). Bolletino della Società Entomologica Italiana, 145, 925.

Casale, A., Giachino, P.M., Vailati, D. \& Rampini, M. (1991) Note sulla linea filetica di Phaneropella Jeannel, 1910 con descrizione di tre nuovi sottogeneri e di una nuova specie di Turchia (Coleoptera Cholevidae Bathysciinae). Natura Bresciana, 26, 197-222.

Casale, A., Grafitti, G. \& Latella, L. (2009) The Cholevidae (Coleoptera) of Sardinia. Zootaxa, 2318, 290-316.

Casale, A., Jalžić, B., Lohaj, R. \& Mlejnek, R. (2012) Two new highly specialised subterranean beetles from the Velebit Massif (Croatia): Velebitaphaenops (new genus) giganteus Casale \& Jalžić, new species (Coleoptera: Carabidae: Trechini) and Velebitodromus ozrenlukici Lohaj, Mlejnek \& Jalžić, new species (Coleoptera: Cholevidae: Leptodirini). Natura Croatica, 21, 129-153.

Christiansen, K. (1965) Behavior and form in the evolution of cave Collembola. Evolution, 19, 529 537.

Christiansen, K. \& Culver, D. (1987) Biogeography and distribution of cave Collembola. Journal of Biogeography, 14, 459-477.

Comas, J. (1977) Nueva especie de Spelaeochlamys Dieck (Col. Bathysciinae). Miscelánea Zoológica, 4, 217-219.

Comas, J. (1978) Nueva especie del genero Typhlochlamys Esp. (Col. Catopidae). Miscelánea Zoológica, 4, 161-163.

Comas, J. (1990) Anillochlamys negrei sp. n. de Bathysciinae del País Valencia (España) (Col., Cholevidae). Miscelánea Zoológica, 14, 69-72.

Cooter, J. \& Švec, Z. (2011) Agathidium (Macroceble) curtisternum sp. nov. from Turkey (Coleoptera: Leiodidae: Leiodinae). Klapalekiana, 47, 13-16.

Ćurčić, S.B., Antić, D.Ž., Curčić, N.B. \& Ćurčić, B.P.M. (2013) Remyella montenegrina, a new troglobitic leiodid beetle (Coleoptera: Leiodidae: Leptodirini) from Northeastern Montenegro. Archives of Biological Sciences, Belgrade, 65, 1217-1222.

Ćurčić, S.B. \& Brajković, M.M. (2002) Magdelainella bozidarcurcici n. sp. (Coleoptera, Cholevidae), a new endemic beetle from Southwest Serbia. Archives of Biological Sciences, Belgrade, 54, $97-100$. 
Ćurčić, S.B., Brajković, M.M., Ćurčić, B.P.M. \& Ćurčić, N.B. (2006) A new cave-dwelling and endemic species of the genus Pholeuonopsis (Coleoptera, Leiodidae) from Serbia. Biologia, Bratislava, 61, 497-501. DOI 10.2478/s11756-006-0082-0.

Ćurčić, S.B., Brajković, M.M., Ćurčić, B.P.M., Schönmann, H., Makarov, S.E., Mitić, B.M. \& Tomić, V.T. (2004) Kosaniniella javorensis n. gen., n. sp., from Southwest Serbia, with notes on the evolutionary status of Knirschiella Guéorguiev (Cholevidae, Coleoptera). Archives of Biological Sciences, Belgrade, 56, 115-120.

Ćurčić, S.B., Brajković, M.M., Curčić, B.P.M. \& Waitzbauer, W. (2007) Rozajella jovanvladimiri gen. n., sp. n. (Leptodirini, Leiodidae, Coleoptera), from East Montenegro, with notes on its phylogeny. Archives of Biological Sciences, Belgrade, 59, 145-150. DOI 10.2298/ABS0702145C.

Ćurčić, S.B., Ćurčić, B.P.M., Makarov, S.E., Mitić, B.M. \& Mihajlova, B. (2005) On three new highaltitude endemic leiodids (Coleoptera: Leiodidae) from the Balkan Peninsula. Entomologica Fennica, 16, 309-316.

Ćurčić, S.B., Makarov, S.E. \& Ćurčić, B.P.M. (2009) A revision of Magdelainella Jeannel, with a description of M. Studenicae sp. N.(Coleoptera, Leiodidae, Leptodirini), a new endogean beetle from Serbia. Archives of Biological Sciences, Belgrade, 61, 757-765.

Ćurčić, S.B., Peceij, J.M. \& Stojkoska, E. (2002) A redescription of Charonites orlovacensis Reitter (Bathysciinae, Cholevidae, Coleoptera), with some notes on its systematic position and ecology. Archives of Biological Sciences, Belgrade, 54, 129-132.

Ćurčić, S.B., Pešić, V., Ćurčić, B.P.M., Ćurčić, N. \& Rađa, T. (2012) A new cave-dwelling species of the genus Parapropus Ganglbauer (Coleoptera: Leiodidae: Leptodirini) From Bosnia and Herzegovina. Archives of Biological Sciences, Belgrade, 64, 1229-1233.

Ćurčić, S., Rađa, T., Mulaomerović, J., Vrbica, M., Antić, D., Ćurčić, B., Rađa, B. \& Vesović, N. (2014a) Three new cave-dwelling leiodid beetles (Coleoptera: Leiodidae: Cholevinae: Leptodirini) from Bosnia and Herzegovina. Archives of Biological Sciences, Belgrade, 66, 919-933.

Ćurčić, S.B., Schönmann, H., Brajković, M.M. \& Ćurčić, B.P.M. (2008b) Serboleonhardella gen. n., based on Proleonhardella remyi Jeannel (Leptodirini, Leiodidae, Coleoptera), from a cave in Southwestern Serbia. Advances in Arachnology and Developmental Biology. Papers dedicated to Professor Božidar P.M. Ćurčić. (ed. by S.E. Makarov \& R.N. Dimitrijević), pp. 463-47. Institute of Zoology, Belgrade.

Ćurčić, S., Vrbica, M., Vesović, N., Mulaomerović, J. \& Ćurčić, B. (2014b) Pholeuonopsis (Pholeuonopsis) perucensis sp. n., a new troglobitic leiodid beetle (Coleoptera: Leiodidae: Cholevinae: Leptodirini) from Bosnia and Herzegovina. Ecologica Montenegrina, 1, 176-183.

Ćurčić, S., Waitzbauer, W., Zolda, P., Brajković, M.M. \& Ćurčić, B.P.M. (2008a) New cave-dwelling species of the genus Remyella Jeannel (Leptodirini, Leiodidae, Coleoptera) from Serbia. Archives of Biological Sciences, Belgrade, 60, 109-115.

Eimüller, T., Guttmann, P. \& Gorb, S.N. (2008) Terminal contact elements of insect attachment devices studied by transmission X-ray microscopy. Journal of Experimental Biology, 211, 1958-1963.

Etonti, M. (2001) Pretneria droveniki sp. n. della Slovenia Occ. (Coleoptera: Cholevidae: Leptodirinae). Acta entomologica, 9, 21-26.

Faille, A., Bourdeau, C. \& Fresneda, J. (2009) Eskualdunella delespierrei Coiffait, 1950: la clé inattendue d'une énigme biogéographique (Coleoptera, Leiodidae). Bulletin de la Société Entomologique de France, 114, 469-473.

Fall, H.C. (1937) The North American species of Nemadus Thom., with descriptions of new species (Coleoptera, Silphidæ). Journal of the New York Entomological Society, 45, 335-340. 
Fresneda, J. \& Bourdeau, C. (2012) Una nueva especie del género Bathysciola Jeannel, 1910 de la vertiente norte de los Pirineos, Francia (Coleoptera: Leiodidae: Cholevinae: Leptodirini). Heteropterus Revista de Entomología, 12, 21-27.

Fresneda, J., Bourdeau, C. \& Faille, A. (2009) Baronniesia delioti gen. n. sp. n., a new subterranean Leptodirini from the French Pyrenees (Coleoptera: Leiodidae: Cholevinae). Zootaxa, 1993, 116.

Fresneda, J., Bourdeau, C. \& Faille, A. (2011a) Le genre Paratroglophyes Fourès, 1954: description d'une nouvelle espèce du massif du mont Valier, Pyrénées centrales, France (Coleoptera, Leiodidae, Cholevinae, Leptodirini). Bulletin de la Société Entomologique de France, 116, 355-363.

Fresneda, J. \& Dupré, E. (2010) Nafarroa sorogainensis n. g. n. sp., un nuevo Leptodirini hipógeo de lós Pirineos navarros (España) (Coleoptera: Leiodidae: Cholevinae). Heteropterus Revista de Entomología, 10, 1-14.

Fresneda, J. \& Escolà, O. (2000) Distribución del género Stygiophyes Fresneda, 1998 y descripción de Stygiophyes aldomai allomorphus ssp. n. (Coleoptera, Cholevidae, Leptodirinae). Miscelànea Zoològica, 23, 55-68.

Fresneda, J., Grebennikov, V.V. \& Ribera, I. (2011b) The phylogenetic and geographic limits of Leptodirini (Insecta: Coleoptera: Leiodidae: Cholevinae), with a description of Sciaphyes shestakovi sp. n. from the Russian Far East. Arthropod Systematics \& Phylogeny, 69, 99-123.

Fresneda, J. \& Hernando, C. (1988) Speonomus aldomai sp. n. (Coleoptera, Catopidae) nuevo Bathysciinae de L'Alta Ribagorça (Lleida). Miscelánea Zoológica, 12, 163-169.

Fresneda, J. \& Hernando, C. (1990) Speonomus torresi n. sp., nuevo Bathysciinae (Coleoptera, Catopidae) del Pallars Sobirà, Lleida. Lleida Ciènces, 48, 85-90.

Fresneda, J. \& Hernando, C. (1991) Speonomus kryophilus n. sp. (Coleoptera, Cholevidae) nuevo Bathysciinae del Pirineo Catalán. Lleida Ciènces, 49, 259-264.

Fresneda, J. \& Hernando, C. (1994a) Descripción de Bellesia n. gen. (Col. Cholevidae) Del Pirineo de Huesca (España) y consideraciones sobre las estructuras Del saco interno Del edeago. Mémoires de Biospéologie, 21, 57-62.

Fresneda, J. \& Hernando, C. (1994b) Speonomus escollae n. sp. (Coleoptera, Cholevidae) del M.S.S. del Prepirineo Oscense (España). Mémoires de Biospéologie, 21, 63-66.

Fresneda, J., Perreau, M. \& Vanderbergh, C. (2010) Une nouvelle espèce pyrénéenne et une nouvelle synonymie dans le genre Bathysciola Jeannel, 1910 (Coleoptera, Leiodidae, Cholevinae, Leptodirini). Bulletin de la Société Entomologique de France, 115, 427-433.

Fresneda, J. \& Salgado, J.M. (2001) Quaestus (Quaestus) asturicus n. sp. (Coleoptera, Cholevidae, Leptodirinae) de la Sierra de Cuera (Asturias, España). Ecología y biogeografia. Boletín de la Asociación Española de Entomología, 25, 103-114.

Fresneda, J., Salgado, J.M. \& Ribera, I. (2007) Phylogeny of Western Mediterranean Leptodirini, with an emphasis on genital characters (Coleoptera: Leiodidae: Cholevinae). Systematic Entomology, 32, 332-358.

Geiselhardt, S.F., Lamm, S., Gack, C. \& Peschke, K. (2010) Interaction of liquid epicuticular hydrocarbons and tarsal adhesive secretion in Leptinotarsa decemlineata Say (Coleoptera: Chrysomelidae). Journal of Comparative Physiology A, 196, 369-378. DOI 10.1007/s00359010-0522-8.

Giachino, P.M. (1988) Note sui catopidi (Coleoptera) Del Vicino Orfiente e descrizione di Choleva (Choleva) cavazzutii n. sp. Natura Bresciana, 25, 203-211.

Giachino, P.M. (1998) Una nuova Bathysciola del caucaso (Coleoptera Cholevidae: Leptodirinae). Natura Bresciana, 31, 105-112.

Giachino, P.M. (2006) Bathyscidius comottiorum n. sp. del Kosovo (Coleoptera, Cholevidae, Leptodirinae). Rivista del Museo Civico di Scienze Naturali “Enrico Caffi”, Bergamo, 24, 11 15 . 
Giachino, P.M., Bregović, P. \& Jalžić, B. (2011) Five new species of the Genus Leptomeson Jeannel, 1924 from Croatia and Bosnia and Herzegovina (Coleoptera, Cholevidae, Leptodirinae). Natura Croatica, 20, 355-374.

Giachino, P.M. \& Gueorguiev, B.V. (2006) Gueorguievella n. gen. petrovi n. sp. of Leptodirinae from Bulgaria (Coleoptera, Cholevidae). Fragmenta Entomologica, 38, 55-63.

Giachino, P.M. \& Gueorguiev, B.V. (2008) Studi tassonomici su Leptodirinae di Bulgaria, con revisione dei generi Beskovia e Beronia e checklist delle specie conosciute (Coleoptera Cholevidae). Memorie della Società Entomologica Italiana, 87, 79-115.

Giachino, P.M. \& Gueorguiev, V.B. (1996) Il genere Radevia Knirsch, 1925 (Coleoptera Cholevidae Leptodirinae). Natura Bresciana, 30, 247-257.

Giachino, P.M., Latella, L. \& Vailati, D. (2013) Two new species of the genus Anemadus Reitter, 1885, from the Near East (Coleoptera: Cholevidae). Zootaxa, 3718, 378-386.

Giachino, P.M. \& Moravec, J. (2009) Reinholdina deelemanorum gen. n., sp. n. from Bosnia and Herzegovina (Coleoptera: Cholevidae: Leptodirinae). Studies and reports of District Museum Prague-East, Taxonomical Series, 5, 37-42.

Gnaspini, P. (1991) Brazilian Cholevidae (Coleoptera), with emphasis on cavernicolous species. I. Genus Dissochaetus. Giornale Italiano di Entomologia, 5, 325-340.

Gnaspini, P. (1994) The genus Eucatops (Coleoptera, Cholevidae, Eucatopinae) - description of new species and considerations on its systematic position. Iheringia (Zoologia), 76, 33-42.

Gnaspini, P. (1996) Phylogenetic analysis of the tribe Ptomaphagini, with description of new Neotropical genera and species (Coleoptera, Leiodidae, Cholevinae, Ptomaphagini). Papéis Avulsos de Zoologia, 39, 509-556.

Gnaspini, P. \& Peck, S.B. (1996) The Adelopsis of Costa Rica and Panama (Coleoptera, Leiodidae, Cholevinae, Ptomaphagini). Papéis Avulsos de Zoologia, 39, 405-441.

Gorb, E., Voigt, D., Eigenbrode, S.D. \& Gorb, S. (2008) Attachment force of the beetle Cryptolaemus montrouzieri (Coleoptera, Coccinellidae) on leaflet surfaces of mutants of the pea Pisum sativum (Fabaceae) with regular and reduced wax coverage. Arthropod-Plant Interactions, 2, 247-259. DOI 10.1007/s11829-008-9049-0.

Gorb, S.N. (1998) The design of the fly adhesive pad: distal tenent setae are adapted to the delivery of an adhesive secretion. Proceedings of the Royal Society of London B, 265, 747-752.

Gorb, S.N. (2008) Biological attachment devices: exploring nature's diversity for biomimetics. Philosophical Transactions of the Royal Society A, 366, 1557-1574. DOI10.1098/rsta.2007.2172.

Gorb, S.N. \& Beutel, R.G. (2001) Evolution of locomotory attachment pads of hexapods. Naturwissenschaften, 88, 530-534. DOI 10.1007/s00114-001-0274-y.

Gorb, S.N., Beutel, R.G. Gorb, E.V., Jiao, Y., Kastner, V., Niederegger, S., Popov, V.L., Scherge, M., Schwarz, U. \& Vötsch, W. (2002) Structural design and biomechanics of friction-based releasable attachment devices in insects. Integrative and Comparative Biology, 42, 1127-1139.

Gorb, S., Gorb, E. \& Kastner, V. (2001) Scale effects on the attachment pads and friction forces in syrphid flies (Diptera, Syrphidae). Journal of Experimental Biology, 204, 1421-1431.

Grohmann, C., Blankenstein, A., Koops, S. \& Gorb, S.N. (2014) Attachment of Galerucella nymphaeae (Coleoptera, Chrysomelidae) to surfaces with different surface energy. Journal of Experimental Biology, 217, 4213-4220. DOI 10.1242/jeb.108902.

Gueorguiev, B.V. (2007) Description of Ceuthophyes enormis nov. sp. from Albania, and notes on the morphology of Henrotiella eubeensis (Coleoptera: Leiodidae: Leptodirini). Bollettino del Museo Civico di Storia Naturale di Verona, Botanica Zoologia, 31, 75-82.

Gueorguiev, V.B. (1965) Notes sur lês Coleopteres cavernicoles de Bulgarie. V. Balcanobius etropolensis gen. n., sp. n. - nouveau Bathysciinae cavernicole Du groupe des Brachyscapes (Catopidae, Coleoptera). International Journal of Speleology, 1, 393-397. 
Haas, F. \& Gorb, S. (2004) Evolution of locomotory attachment pads in the Dermaptera (Insecta). Arthropod Structure \& Development, 33, 45-66.

Hatch, M.H. (1927) Studies on Silphinae. Journal of the New York Entomological Society, 35, 331371.

Hatch, M.H. (1929) The genera and subgenera of Leiodidæ and Clambidæ. Journal of the New York Entomological Society, 37, 1-6.

Hatch, M.H. (1933) Studies on the Leptodiridæ (Catopidæ) with descriptions of new species. Journal of the New York Entomological Society, 41, 187-236, 238-239.

Hill, D.E. (1977) The pretarsus of salticid spiders. Zoological Journal of the Linnean Society, 60, 319338.

Horn, G.H. (1880) Synopsis of the Silphidæ of the United States with reference to the genera of other countries. Transactions of the American Entomological Society and Proceedings of the Entomological Section of the Acadmy of Natural Sciences, 8, 219-32.

Hoshina, H. (2009) A taxonomic revision of the subfamily Coloninae (Coleoptera: Leiodidae) from Japan and Taiwan. Tijdschrift voor Entomologie, 152, 237-286.

Hoshina, H. (2012) Review of the tribes Sogdini and Leiodini from Japan and North Chishima Islands. Part II. Genera Hydnobius and Leiodes (Coleoptera: Leiodidae). Acta Entomologica Musei Nationalis Pragae, 52 (suppl. 1), 1-168.

Hoshina, H. \& Perreau, M. (2008) A second species of the genus Sciaphyes (Coleoptera: Leiodidae: Cholevinae: Sciaphyini) from Japan. Annales de la Société Entomologique de France (n.s.), 44, 157-160.

Hoshina, H. \& Sugaya, H. (2003) A taxonomic study of the genus Ptomaphaginus (Coleoptera: Leiodidae: Cholevinae) from the Ryukyu Islands, Japan. Entomological Review of Japan, 58, $121-131$.

Ishii, S. (1987) Adhesion of a leaf feeding ladybird Epilachna vigintioctomaculta (Coleoptera: Cocciinellidae) on a vertically smooth surface. Applied Entomology and Zoology, 22, 222-228.

Jeannel, R. (1936) Monographie des Catopidae. Mémoires du Muséum National d'Histoire Naturelle (n.s.), 1, 1-433.

Latella, L. (2002) Un nuovo leptodirino dei Monti Aurunci (Coleoptera, Cholevidae). Bollettino del Museo Civico di Storia Naturale di Verona, Botanica Zoologia, 26, 129-135.

Latella, L. (2012) Lectotype designation and redescription of Bathysciola destefanii (Ragusa, 1881) (Coleoptera, Cholevidae) from Sicily (Italy). Bollettino del Museo Civico di Storia Naturale di Verona, Botanica Zoologia, 36, 67-72.

Latella, L. \& Rampini, M. (1994) Bathysciola delayi, nuova specie di Leptodirino dei Monti Lepini (Coleoptera, Cholevidae). Fragmenta entomológica, 26, 141-150.

Leschen, R.A.B. (2000) Pseudoliodini (Coleoptera: Leiodidae: Leiodinae) of New Zealand. New Zealand Entomologist, 22, 33-44.

Liu, Z. \& Liang, A.-P. (2013) Ultrastructure of the tarsus in Oides decempunctatus (Billberg) (Coleoptera: Chrysomelidae). Journal of the Kansas Entomological Society, 86, 122-132. DOI 10.2317/JKES120825.1.

McKenna, D.D., Farrell, B.D., Caterino, M.S., Farnum, C.W., Hawks, D.C., Maddison, D.R., Seago, A.E., Short, A.E.Z., Newton, A.F. \& Thayer, M.K. (2015) Phylogeny and evolution of Staphyliniformia and Scarabaeiformia: forest litter as a stepping stone for diversification of nonphytophagous beetles. Systematic Entomology, 40, 35-60. DOI 10.1111/syen.12093.

Miller, K.B. \& Wheeler, Q.D. (2004) Two new genera of Agathidiini from the Nearctic and Neotropical regions (Coleoptera: Leiodidae). Coleopterists Bulletin, 58, 466487.

Miller, K.L. \& Wheeler, Q.D. (2005) Slime-mold beetles of the genus Agathidium Panzer in North and Central America, Part II. Coleoptera: Leiodidae. Bulletin of the American Museum of Natural History, 291, 1-167. 
Moldovan, O.T. (2000) Révision de Drimeotus s.s. Miller, 1856 (Coleoptera, Cholevidae, Leptodirinae) de Transylvanie (Roumanie) avec description de deux nouvelles espèces et clé de détermination des taxa. Zoosystema, 22, 139-152.

Moldovan, O.T., Racoviţă, G. \& Dunay, G. (2007) Reconsidering Pholeuon C. Hampe (Coleoptera: Leiodidae: Cholevinae), with the description of a new subgenus. Zootaxa, 1449, 31-43.

Moon, M.-J., Park, J.-G., Koh, S.-H. \& Choi, W.-I. (2013) Microstructure of the tarsal adhesive organs in the bark beetle Ips acuminatus, and their implication as external carriers of pathogens. Journal of Asia-Pacific Entomology, 16, 181-187.

Nakane, T. (1982) New or little-known Coleoptera from Japan and its adjacent regions. XXXV. Reports of the Faculty of Science, Kagoshima University (Earth Scienc and Biology), 15, 101111.

Newton, A.F. (1982) Agathidiodes Portevin, new synonym of Stetholiodes Fall (Coleoptera: Leiodidae: Anisotomini). Psyche, 89, 337-338.

Newton, A.F. (1998) Phylogenetic problems, current classification and generic catalog of World Leiodidae (including Cholevidae). Museo Regionale di Scienze Naturali di Torino Atti, 8, 41177.

Newton, A.F. (2016) Leiodidae Fleming, 1821. In: Beutel, R.G. and Leschen, R.A.B., (Eds.), Handbook of Zoology, Vol. IV, Arthropoda: Insecta; Coleoptera, Morphology and Systematics (Archostemata, Adephaga, Myxophaga, Polyphaga partim), Vol. 1, $2^{\text {nd }}$ ed. Walter De Gruyter, Berlin and New York, pp. 364-376.

Niederegger, S. \& Gorb, S. (2003) Tarsal movements in flies during leg attachment and detachment on a smooth substrate. Journal of Insect Physiology, 49, 611-620.

Niederegger, S., Gorb, S. \& Jiao, Y. (2002) Contact behaviour of tenent setae in attachment pads of the blowfly Calliphora vicina (Diptera, Calliphoridae). Journal of Comparative Physiology A, 187, 961-970. DOI 10.1007/s00359-001-0265-7.

Njunjić, I., Perreau, M. \& Pavićević, D. (2015) Two new species of the genus Anthroherpon Reitter, 1889 from northern Montenegro with notes on the "A. ganglbaueri" species group (Coleoptera: Leiodidae: Leptodirini). Zootaxa, 3915, 403-412.

Paoletti, M. (1972) Un nuovo Catopide pholeuonoide del Cansiglio (Prealpi carniche) (Col. Bathysciinae). Bolletino Del Museo Civico di Storia Naturale di Venezia, 22, 119-131.

Park, S.-J., Leschen, R.A.B. \& Ahn, K.-J. (2014) Phylogeny of the Agathidiini Westwood (Coleoptera: Leiodidae) and implications for classification and contractile morphology. Systematic Entomology, 39, 36-48. DOI 10.1111/syen.12034.

Parsaiyan, H., Barazandeh, F., Rezaei, S.M., Parsaiyan, M. \& Safdari, M. (2009) Wide-end fibers and their adhesion performance in biological attachment systems. International Journal of Adhesion \& Adhesives, 29, 444-450.

Peck, S.B. (1973) A systematic revision and the evolutionary biology of the Ptomaphagus (Adelops) beetles of North America (Coleoptera; Leiodidae; Catopinae), with emphasis on caveinhabiting species. Bulletin of the Museum of Comparative Zoology, 145, 29-162.

Peck, S.B. (1974) The eyeless Catopocerus beetles (Leiodidae) of Eastern North America. Psyche, 81, 377-397.

Peck, S.B. (1977) A review of the distribution and biology of the small carrion beetle Prionochaeta opaca of North America (Coleoptera; Leiodidae; Catopinae). Psyche, 83, 299-307.

Peck, S.B. (1998) Revision of the Colenis of America North of Mexico (Coleoptera: Leiodidae: Leiodinae: Pseudoliodini). Canadian Entomologist, 130, 55-65.

Peck, S.B. (2003) The eyeless inquiline genera Parabystus Portevin and Scotocryptus Girard of Costa Rica and Panama inhabitants of nests of stingless bees. Sociobiology, 42, 1-16.

Peck, S.B. \& Cook, J. (2002) Systematics, distributions, and bionomics of the small carrion beetles (Coleoptera: Leiodidae: Cholevinae: Cholevini) of North America. Canadian Entomologist, 134, 723-787. 
Peck, S.B. \& Cook, J. (2003) Neotropical species of Dietta (Coleoptera: Leiodidae: Leiodinae: Estadiini). Canadian Entomologist, 135, 775-810.

Peck, S.B. \& Cook, J. (2005) The genus Eucatops of Costa Rica (Coleoptera: Leiodidae, Cholevinae, Eucatopini). Canadian Entomologist, 137, 283-303.

Peck, S.B. \& Cook, J. (2007) Systematics, distributions, and bionomics of the Neoeocatops gen. nov. and Nemadus of North America (Coleoptera: Leiodidae: Cholevinae: Anemadini). Canadian Entomologist, 139, 87-117.

Peck, S.B. \& Cook, J. (2009) Review of the Sogdini of North and Central America (Coleoptera: Leiodidae: Leiodinae) with descriptions of fourteen new species and three new genera. Zootaxa, 2102, 1-74.

Peck, S.B. \& Cook, J. (2011) Systematics, distributions and bionomics of the Catopocerini (eyeless soil fungivore beetles) of North America (Coleoptera: Leiodidae: Catopocerinae). Zootaxa, 3077, 1-118.

Peck, S.B. \& Cook, J. (2013a) A revision of the species of Anogdus LeConte of the United States and Canada (Coleoptera: Leiodidae: Leiodinae: Leiodini). Insecta Mundi, 0290, 1-27.

Peck, S.B. \& Cook, J. (2013b) Systematics and distributions of the genera Cyrtusa Erichson, Ecarinosphaerula Hatch, Isoplastus Horn, Liocyrtusa Daffner, Lionothus Brown, and Zeadolopus Broun of the United States and Canada (Coleoptera: Leiodidae: Leiodinae: Leiodini). Insecta Mundi, 0310, 1-32.

Peck, S.B. \& Cook, J. (2014) A review of the small carrion beetles and the round fungus beetles of the West Indies (Coleoptera: Leiodidae), with descriptions of two new genera and 61 new species. Insecta Mundi, 0397, 1-76.

Peck, S.B. \& Skeley, P.E. (2001) Small carrion beetles (Coleoptera: Leiodidae: Cholevinae) from burrows of Geomys and Thomomys pocket gophers (Rodentia: Geomyidae) in the United States. Insecta Mundi, 15, 139-149.

Peisker, H., Heepe, L., Kovalev, A.E. \& Gorb, S.N. (2014) Comparative study of the fluid viscosity in tarsal hairy attachment systems of flies and beetles. Journal of the Royal Society Interface, 11, 20140752. DOI 10.1098/rsif.2014.0752.

Perreau, M. (2000) Catalogue des Coléoptères Leiodidae Cholevinae et Platypsyllinae. Memoires de la Societé Entomologique de France, 4, 1-460.

Perreau, M. (2002) Nouvelles espèces de Leiodidae Cholevinae (Coleoptera), notes sur quelques espèes mal connes et correction d'une homonymie. Mitteilungen der Schweizerischen Entomologischen Gesellschaft, 75, 41-50.

Perreau, M. (2003) Contribution à la connaissance des Bathysciina de la «série d'Aphaobius» (sensu Jeannel, 1924) (Coleoptera: Leiodidae, Cholevinae, Leptodirini). Annales de la Société Entomologique de France (n.s.), 39, 211-224.

Perreau, M. (2004a) Contribution à la connaissance du genre Nargus Thomson, 1867 (Coleoptera, Leiodidae, Cholevinae). Bulletin de la Société Entomologique de France, 109, 461-468.

Perreau, M. (2004b) Contribution à la connaissance des Leiodidae (Coleoptera). Mitteilungen der Schweizerischen Entomologischen Gesellschaft, 77, 197-212.

Perreau, M. (2008) Pavicevicia n. gen., a new genus with one new species of Bathyciotina from Kosovo (Coleoptera, Leiodidae, Cholevinae, Leptodirini). Advances in the studies of the fauna of the Balkan Peninsula. Papers dedicated to the memory of Guido Nonveiller. Monograph 22 (ed. by D. Pavićević \& M. Perreau), pp. 177-182. Institute for Nature Conservation of Serbia, Belgrade.

Perreau, M. (2009) Nouveaux Ptomaphagini et Anemadini souterrains, dont la première espèce anophtalme d'Anemadus (Coleoptera : Leiodidae : Cholevinae). Annales de la Société Entomologique de France (n.s.), 45, 1-10. 
Perreau, M. (2010) Une nouvelle espèce de Phaneropella Jeannel, 1910, de Turquie (Coleoptera, Leiodidae, Cholevinae, Leptodirini). Bulletin de la Société Entomologique de France, 115, 47 50.

Perreau, M. (2012) Description of a new genus and two new species of Leiodidae (Coleoptera) from Baltic amber using phase contrast synchrotron X-ray microtomography. Zootaxa, 3455, 81-88.

Perreau, M. \& Pavićević, D. (2008a) One new genus and two new species of Leptodirina from Montenegro (Coleoptera, Leiodidae, Cholevinae). Advances in the studies of the fauna of the Balkan Peninsula. Papers dedicated to the memory of Guido Nonveiller. Monograph 22 (ed. by D. Pavićević \& M. Perreau), pp. 199-210. Institute for Nature Conservation of Serbia, Belgrade.

Perreau, M. \& Pavićević, D. (2008b) The genus Hadesia Müller, 1911 and the phylogeny of Anthroherponina (Coleoptera, Leiodidae, Cholevinae, Leptodirini). Advances in the studies of the fauna of the Balkan Peninsula. Papers dedicated to the memory of Guido Nonveiller. Monograph 22 (ed. by D. Pavićević \& M. Perreau), pp. 215-239. Institute for Nature Conservation of Serbia, Belgrade.

Perreau, M. \& Perkovsky, E.E. (2015) Further description of Catops nathani Perkovsky 2001 from Late Eocene Baltic amber (Coleoptera: Leiodidae: Cholevinae: Cholevini) using phase contrast synchrotron X-ray microtomography. Annales de la Société Entomologique de France (n.s.), 50, 414-417.

Perreau, M. \& Růžička, J. (2007) Systematic position of Perkovskius Lafer 1989 (Coleoptera: Leiodidae: Catopocerinae), with description of a second species from the Far East of Russia. Annales de la Société Entomologique de France (n.s.), 43, 257-264.

Perreau, M. \& Tafforeau, P. (2011) Virtual dissection using phase-contrast X-ray synchrotron microtomography: reducing the gap between fossils and extant species. Systematic Entomology, 36, 573-580.

Perreau, M. \& Tronquet, M. (2002) Révision du genre Perriniella Jeannel et description d'une nouvelle espèce des Pyrénées Françaises (Coleoptera: Leiodidae, Cholevinae, Leptodirini). Annales de la Société Entomologique de France (n.s.), 37, 481-490.

Piva, E. (2005) Nuove specie di Orostygia e Oryotus, con note sinonimiche (Coleoptera Cholevidae). Memorie della Società Entomologica Italiana, 84, 3-44.

Pohl, H. \& Beutel, R.G. (2004) Fine structure of adhesive devices of Strepsiptera (Insecta). Arthropod Structure \& Development, 33, 31-43.

Polak, S. (2002) Spelaeodromus sneznikensis sp. nov. from Slovenia (Coleoptera: Cholevidae: Leptodirinae). Acta entomologica slovenica, 10, 5-12.

Polak, S. \& Bognolo, M. (2003) Prospelaeobates brelihi sp. nov., a new leptodirine beetle from Slovenia (Coleoptera: Cholevidae). Acta entomologica slovenica, 11, 17-30.

Polak, S. \& Jalžić, B. (2009) Blattochaeta marianii kusijanovici, new subspecies (Coleoptera, Leiodidae, Cholevinae) from Croatia. Natura Croatica, 18, 15-27.

Portevin, G. (1914) Silphides et liodides nouveaux. Annales de la Société Entomologique de Belgique, 58, 190-198.

Rizzo, V. \& Comas, J. (2015) A new species of Troglocharinus Reitter, 1908 (Coleoptera, Leiodidae, Cholevinae, Leptodirini) from southern Catalonia, with a molecular phylogeny of the related species group. Zootaxa, 3946, 104-112.

Roubik, D.W. \& Wheeler, Q.D. (1982) Flightless beetles and stingless bees: Phoresy of scotocryptine beetles (Leiodidae) on their meliponine hosts (Apidae). Journal of the Kansas Entomological Society, 55, 125-135.

Růžička, J. (1997) A new species of Attaephilus from Turkey (Coleoptera: Leiodidae: Cholevinae). Entomological Problems, 28, 57-59.

Růžička, J. (1999) A new apterous and microphthalmic species of Anemadus (Coleoptera: Leiodidae: Cholevinae) from China. Revue Suisse de Zoologie, 106, 621-626. 
Růžička, J. \& Perreau, M. (2007) Morphological variation and distribution of Colon (Myloechus) koghiense (Coleoptera: Leiodidae) from the New Caledonia. Acta Societatis Zoologicae Bohemicae, 71, 21-24.

Růžička, J. \& Perreau, M. (2011) A revision of the Chinese Catops Paykull 1798 of the Catops fuscus species group (Coleoptera: Leiodidae: Cholevinae). Annales de la Société Entomologique de France (n.s.), 47, 280-292.

Salgado, J.M. (1999) A new Quaestus Schaufuss 1861 (Coleoptera: Leiodidae: Leptodirinae) from the Cantabrian Mountains (Spain). Canadian Entomologist 131, 211-218.

Salgado, J.M. (2000) Revision of the genus Nemadiolus Jeannel, 1936 (Coleoptera: Leiodidae: Cholevinae). Elytron, 14, 159-174.

Salgado, J.M. (2002) Revision of the genera Nemadiopsis and Falkonemadus (Coleoptera: Leiodidae: Cholevinae). European Journal of Entomology, 99, 505-521.

Salgado, J.M. (2005a) Description of new genera and species of the subtribe Eunemadina from Chile. New data on other genera (Coleoptera, Leiodidae, Cholevinae). Mitteilungen aus dem Museum für Naturkunde in Berlin, Deutsche Entomologische Zeitschrift, 52, 191-216. DOI 10.1002/mmnd.200310012.

Salgado, J.M. (2005b) New species of Leiodidae (Coleoptera) and new records from the Neotropical Region. Revue Suisse de Zoologie, 112, 963-982.

Salgado, J.M. (2006a) Nuevas aportaciones al conocimiento de Camiarinae y Cholevinae (Coleoptera: Leiodidae) neotropicales y descripción de una nueva especie de Chile. Boletín del Museo Nacional de Historia Natural, Chile, 55, 87-111.

Salgado, J.M. (2006b) Dissochaetus machupicchuensis sp. n. una propuesta de reordenación del grupo «D. curtus» Jeannel, 1936 (Coleoptera: Leiodidae: Cholevinae). Elytron, 20, 5-13.

Salgado, J.M. (2011a) Nuevos datos y nuevas especies de las subfamilias Camiarinae y Cholevinae de Chile (Coleoptera, Leiodidae). Nouvelle Revue d'Entomologie (n.s.), 27, 237-257.

Salgado, J.M. (2011b) Una especie nueva del género Nemadiopsis Jeannel, 1936 de Chile y datos de distribución de las especies de este género (Coleoptera, Leiodidae, Cholevinae, Anemadini). Boletín de la Sociedad Entomológica Aragonesa, 49, 91-102.

Salgado, J.M. (2015a) Agyrtodini de Chile: Géneros nuevos y especies nuevas (Coleoptera: Leiodidae: Camiarinae). Boletín de la Sociedad Entomológica Aragonesa, 56, 85-95.

Salgado, J.M. (2015b) Dos especies nuevas del género Sphaeropelatops Jeannel, 1962. Nuevos datos de Camiarinae y Cholevinae de Brasil, Chile y Panamá (Coleoptera: Leiodidae). Boletín de la Asociación Española de Entomología, 39, 3-39.

Salgado, J.M., Blas, M. \& Fresneda, J. (2003) Nuevos datos sobre el gênero Choleva Latreille, 1796 em la Península Ibérica com la descripción de uma nueva espécie (Coleoptera: Cholevidae). Elytron, 17-18, 47-71.

Salgado, J.M. \& Fresneda, J. (2003) Revision of the section Anillochlamys Jeannel, 1909 (Coleoptera: Leiodidae: Cholevinae: Leptodirini). Annales de la Société Entomologique de France (n.s.), 39, 361-384.

Salgado, J.M. \& Fresneda, J. (2004) Two new taxa of Leptodirini (Coleoptera: Leiodidae, Cholevinae) from the Cantabrian cornice (Asturias, Spain). Biogeographical observations. Revue Suisse de Zoologie, 111, 35-55.

Salgado, J.M. \& Fresneda, J. (2005) The genus Espanoliella Guéorguiev, 1976. E. luquei, sp. nov. (Coleoptera: Leiodidae: Leptodirinae). Subterranean Biology, 3: 87-96.

Salgado, J.M. \& Fresneda, J. (2006) Dos nuevas especies de Anillochlamys Jeannel, 1909 del levante de España (Coleoptera: Leiodidae: Cholevinae: Leptodirini). Heteropterus Revista de Entomología, 6, 19-28.

Salgado, J.M. \& Fresneda, J. (2010) Un nuevo troglobio de la región Cantábrica: Quaestus (Speogeus) jubilationis n. sp. (Coleoptera: Leiodidae: Cholevinae: Leptodirini). Heteropterus Revista de Entomología, 10, 99-106. 
Salgado, J.M., Labrada, L. \& Luque, C.G. (2010) A new cave-dwelling species of Quaestus Schaufuss, 1861 from the Montes de Pas, Northern Spain (Coleoptera: Leiodidae: Leptodirini). Zootaxa, 2484, 25-34.

Salgado, J.M., Labrada, L. \& Luque, C.G. (2011) Un nuevo género y nueva especie de Leptodirini troglobio de la Cordillera Cantábrica (Cantabria, España): Fresnedaella lucius n. gen, n. sp. (Coleoptera: Leiodidae: Cholevinae). Heteropterus Revista de Entomología, 11, 1-12.

Salgado, J.M., Luque, C.G., Labrada, L., Fresneda, J. \& Ribera I. (2012) Revisión del género Cantabrogeus Salgado, 2000, con la descripción de tres nuevas especies hipogeas endémicas de la Cordillera Cantábrica (Coleoptera, Leiodidae, Cholevinae, Leptodirini). Animal Biodiversity and Conservation, 35, 27-50.

Schilthuizen, M. (1984) A new Ptomaphaginus Portevin from Indonesia (Coleoptera: Cholevidae). Entomologische Berichten, 44, 30-32.

Schilthuizen, M. (1990) A revision of Choleva agilis (Illiger, 1798) and related species (Coleoptera: Staphylinoidea: Cholevidae). Zoologische Mededelingen Leiden, 64, 121-153.

Seago, A.E. (2005) Male description and generic review of Agyrtolasia Szymczakowski, with key to genera of Agyrtodini (Coleoptera: Leiodidae: Camiarinae: Agyrtodini). Zootaxa, 1103, 1-15.

Seago, A.E. (2009) Revision of Agyrtodes Portevin (Coleoptera: Leiodidae). Coleopterists Society Monograph, 7, 1-73.

Seago, A.E. \& Leschen, R.A.B. (2011) Revision and phylogeny of Chelagyrtodes Szymczakowski (Coleoptera: Leiodidae: Camiarinae: Agyrtodini). Zootaxa, 3090, 1-20.

Seago, A.E., Leschen, R.A.B. \& Newton, A.F. (2015) Two new high altitude genera of Camiarini (Coleoptera: Leiodidae: Camiarinae) from Australia and New Zealand. Zootaxa, 3957, 300 312.

Seago, A.E. \& Newton, A.F. (2009) A new genus of leiodid beetle from Chile, with generic key and species checklist of described Neopelatopini (Coleoptera: Leiodidae: Camiarinae). Annales Zoologici, 59, 297-304.

Seago, A.E. \& Wheeler, Q.D. (2004) Two new species of Aglyptinus Cockerell with unusual sexually dimorphic antennae and diffraction gratings (Coleoptera: Leiodidae). Coleopterists Bulletin, 58, 235-244.

Sharp, D. (1864) On the British species of Agathidium. Transactions of the Royal Entomological Society of London, 12, 445-452.

Stork, N.E. (1980) A scanning electron microscope study of tarsal adhesive setae in the Coleoptera. Zoological Journal of the Linnean Society, 68, 173306.

Sukontason, K.L., Bunchu, N., Methanitikorn, R., Chaiwong, T., Kuntalue, B. \& Sukontason, K. (2006) Ultrastructure of adhesive device in fly in families calliphoridae, muscidae and sarcophagidae, and their implication as mechanical carriers of pathogens. Parasitology Research, 98, 477-481. DOI 10.1007/s00436-005-0100-0.

Švec, Z. (2002) Sphaeroliodes acuminatus sp. n. (Coleoptera: Leiodidae, Leiodinae) from Taiwan and notes on two other species. Acta Zoologica Academiae Scientiarum Hungaricae, 48, 191-195.

Švec, Z. (2009) A review of Pseudcolenis Reitter, 1884 species (Coleoptera: Leiodidae: Leiodinae). Studies and Reports of District Museum Prague-East, Taxonomical Series, 5, 299-324.

Švec, Z. (2011) New and less known Agathidiini and Pseudoliodini (Coleoptera: Leiodidae: Leiodinae) from China, Nepal and India. Studies and Reports, Taxonomical Series, 7, 417-441.

Švec, Z. (2012a) New Leiodinae (Coleoptera: Leiodidae) from India and Papua New Guinea. Acta Entomologica Musei Nationalis Pragae, 52, 411-424.

Švec, Z. (2012b) A contribution to the knowledge of the Himalayan Leiodinae (Insecta: Coleoptera: Leiodidae). Biodiversität und Naturausstattung im Himalaya IV. (ed. by M. Hartmann \& J. Weipert), pp. 273-282. Naturkundemuseum Erfurt, Erfurt. 
Švec, Z. (2013) A contribution to the knowledge of the Colenisia Fauvel, 1902 species (Coleoptera: Leiodidae: Leiodinae) from continental China, Taiwan and Thailand. Studies and Reports, Taxonomical Series, 9, 537-560.

Švec, Z. \& Cooter, J. (2010) A new species of Leiodes (Col., Leiodidae) from China, with new geographical records of Leiodes species. Entomologist's Monthly Magazine, 146, 101-104.

Szymczakowski, W. (1970) Espèces des familles Catopidae et Colonidae (Coleoptera), provenant de l'Amérique du Sud. The Scientific Results of the Hungarian Soil Zoological Expeditions to South America. 19. Opuscula Zoologica (Budapest), 10, 329-333.

Szymczakowski, W. (1975) Die Catopidae (Coleoptera) der Kanarischen Inseln. Vieraea, 4, 189-200.

Vailati, D. (1973) Nuova specie e nuova razza del genere Ghidinia Pavan, 1939 e discussione sulla sistematica dei Bathysciinae (Coleoptera - Catopidae). Natura Bresciana, 10, 35-75.

Vailati, D. (1974) Una nuova especie di Bathysciino delle Prealpi Bresciane e considerazioni ecologiche sulla distribuzione Del genere Boldoria Jeannel (Coleoptera Catopidae). Natura Bresciana, 11, 25-40.

Vailati, D. (1990) Insubriella paradoxa Nuovo genere nuova specie di Bathysciinae delle Prealpi Italiane (Coleoptera Catopidae). Natura Bresciana, 25, 213-229.

Vailati, D. (1993) Monguzziella grottoloi Nuovo genere nuova specie delle Prealpi Venete (Coleoptera Cholevidae Leptodirinae). Natura Bresciana, 28, 261-278.

Vailati, D. (1995) Ridescrizione di Orostygia tibialis Paoletti, 1979 (Coleoptera Cholevidae Leptodirinae) buona espécie Del massiccio Cansiglio-Monte Cavallo (Prealpi Venete). Natura Bresciana, 31, 121-128.

Vávra, J.C. (2015a) Catopsimorphus (Catopsimorphus) orszuliki sp. nov. (Coleoptera: Leiodidae: Cholevinae) from Turkey. Acta Musei Moraviae, Scientiae biologicae (Brno), 100, 115-121.

Vávra, J.C. (2015b) Review of the subgenus Attumbrinus (Coleoptera: Leiodidae: Cholevinae: Philomessor), with description of Philomessor lackneri sp. nov. from Morocco. Acta Entomologica Musei Nationalis Pragae, 55, 85-103.

Voigt, D., Schuppert, J.M., Dattinger, S. \& Gorb, S.N. (2008) Sexual dimorphism in the attachment ability of the Colorado potato beetle Leptinotarsa decemlineata (Coleoptera: Chrysomelidae) to rough substrates. Journal of Insect Physiology, 54, 765-776.

Walker, G. (1993) Adhesion to smooth surfaces by insects - a review. International Journal of Adhesion and Adhesives, 13, 3-7.

Wang, C.-B. \& Zhou, H.-Z. (2015) Taxonomy of the genus Ptomaphaginus Portevin (Coleoptera: Leiodidae: Cholevinae: Ptomaphagini) from China, with description of eleven new species. Zootaxa, 3941, 301-338.

Wang, C.-B., Růžička, J. \& Zhou, H.-Z. (2015) Nargus (Eunargus) celli sp. nov. (Coleoptera: Leiodidae: Cholevinae: Cholevini), a new species from China. Zootaxa, 4012, 570-580.

Wang, J. \& Liang, A.-P. (2015) Ultrastructure of the fossula spongiosa and pretarsus in Haematoloecha nigrorufa (Stål) (Hemiptera: Heteroptera: Reduviidae: Ectrichodinae). Zootaxa, 3963, 230-239. DOI 10.11646/zootaxa.3963.2.4.

Wang, Q.K., Yang, Y.Z., Li, X.Y., Li, K. \& Zhang, D. (2016) Comparative ultrastructure of pretarsi in five calyptrate species. Parasitology Research, 115, 2213-2222. DOI $10.1007 / \mathrm{s} 004360164963 \mathrm{z}$.

West, T. (1862) The foot of the fly; its structure and action: elucidated by comparison with the feet of other insects. Transactions of the Linnean Society of London, 23, 393-421.

Wheeler, Q.D. (1979) Revision and Cladistics of the Middle American genus Creagrophorus Matthews (Coleoptera: Leiodidae). Quaestiones Entomologicae, 15, 447-479.

Wheeler, Q.D. (1983) Slime mold beetles of the genus Anisotoma (Leiodidae): Supplement 1. Description of a new species of the scopula subgroup from Mexico. Coleopterists Bulletin, 37, $45-48$. 
Wheeler, Q.D. (1986) Rediscovery and cladistic placement of the genus Cainosternum (Coleoptera: Leiodidae). Annals of the Entomological Society of America, 79, 377-383.

Wheeler, Q.D. (1987) A new species of Agathidium associated with an "epimycetic" slime mold Plasmodium on Pleurotus fungi (Coleoptera: Leiodidae - Myxomycetes: Physarales Basidiomycetes: Tricholomataceae). Coleopterists Bulletin, 41, 395-403.

Wheeler, Q.D. \& Miller, K.B. (2005) Slime-mold beetles of the genus Agathidium Panzer in North and Central America, Part I. Coleoptera: Leiodidae. Bulletin of the American Museum of Natural History, 290, 1-95.

Wigglesworth, V.B. (1987) How does a fly cling to the under surface of a glass sheet? Journal of Experimental Biology, 129, 373-376.

Zwick, P. (1979) Contributions to the Knowledge of Australian Cholevidae (Catoptidae auct.; Coleoptera). Australian Journal of Zoology (Suppl. Ser.), 70, 1-56. 
Table 1. List of species examined in this study. Type species are given in bold. [\&F] denotes species where females were also studied.

\begin{tabular}{|c|c|c|c|}
\hline \multicolumn{2}{|c|}{ Systematic assignment } & Species & Provenance \\
\hline \multicolumn{4}{|c|}{ Leiodidae } \\
\hline \multirow{18}{*}{ Camiarinae } & & Agyrtodes ovatus Portevin $[\& \mathrm{~F}]$ & Chile: Talca: Vilches Alto \\
\hline & & Chelagyrtodes crowsoni Szymczakowski $[\& \mathrm{~F}]$ & New Zealand: Otaki, Wairarapa J.; North Is \\
\hline & & Chelagyrtodes davidi Seago \& Leschen & New Zealand: Callaghans Ridge; Ohaura, Nelson \\
\hline & & Chiliopelates pictus (Jeannel) & Chile: Osorno: Aguas Calientes \\
\hline & & Dasypelates sp. & Chile: Osorno: off Osorno \\
\hline & & Dictydiella turneri Jeannel & South Africa: West. Cape Ystemek N.R. \\
\hline & & $\begin{array}{l}\text { Eupelates transversestrigosus (Fairmaire \& } \\
\text { Germain) }\end{array}$ & Chile: Arauco: Rinconada \\
\hline & & Paragyrtodes candens Szymczakowski [\&F] & Australia: Wombat Ck.; off Piccadilly Circus \\
\hline & & Ragytodina tuberculosa Jeannel & Chile: Chiloe: Lago Tepuhuieco; off Chonchi \\
\hline & & Zeagyrtes vitticollis Broun $[\& \mathrm{~F}]$ & New Zealand: ND: Mangamuka Walkway \\
\hline & & Camiarites convexus (Sharp) & New Zealand: AK: Little Barrier I \\
\hline & & Camiarus thoracicus Sharp & New Zealand: (a) Katui, Waipoa; (b) Waimatenui \\
\hline & & Inocatops concinnus (Broun) & New Zealand: Shakespeare Bay, Picton \\
\hline & & Neocamiarus kuscheli Jeannel [\&F] & Chile: Cautín: off Pucon \\
\hline & Neopelatopini & Catopsolius laevicollis Sharp $[\& \mathrm{~F}]$ & C.E. Clarke collection; AMNZ 27281 \\
\hline & & Eublackburniella extranea (Blackburn) & Australia: AS: off Adelaide \\
\hline & & Myrmicholeva sp. [\&F] & Australia: Queensland: nr Mt. Glorious \\
\hline & & Neopelatops edwardsi Jeannel & Chile: Malleco: off Manzanar \\
\hline
\end{tabular}


Sphaeropelatops pilosus Salgado

Undescribed Genus sp. $b$. [\&F]

Catopocerinae Catopocerini

Glacicavicolini

Coloninae

Leiodinae

Estadiini

Leiodini

Sogdini

Agathidiini

Pseudoliodini

Metahydnobius bicolor (Jeannel)
Catopocerus politus Motschulsky

Pinodytes newtoni Peck \& Cook

Glacicavicola bathyscioides Westcott [\&F]

Colon (Mesagyrtes) hirtale (Broun) [\&F]

Dietta huanuco Peck \& Cook

Dietta sp.

Anogdus sp.

(cf.) Leiodes sp. [\&F]

Isoplastus fossor Horn

Lionothus ulkei Brown [\&F]

Zeadolopus spinipes Broun

Hydnobius sp.

Isocolon hílare Broun $[\& \mathrm{~F}]$

Metahydnobius bimaculatus (Jeannel)

Triarthron lecontei Horn

Agathidium oniscoides Palisot de Beauvois Amphicyllis globus (Fabricius)

Anisotoma discolor Melsheimer

Cyrtoplastus sp.

Decuria newtoni Miller \& Wheeler

Gelae sp. [\&F]

Liodopria serricornis (Gyllenhal)

Agaricophagus cephalotes Schmidt

Colenis ora Peck
Chile: Osorno: Parque Nac. Puyehue

New Zealand: (a) BR: Reefton; (b) ND: Trounsen Kauri Park

U.S.A.: WV: Pendleton Co.; off Witmer

U.S.A.: AR: Logan Co.; Mt. Magazine

U.S.A.: Idaho: Fremont Co.; Crystal Falls Ice Cave; off Parker

New Zealand: AK: Noises Is; Otata I (2 males, 1 female)

Peru: Huanuco: Cordillera Azul; off Tingo María

Madagascar: Fianarantsoa: off Ranomafana'

Ecuador: Pichincha: Maquipucuna For. Res.; off Quito

U.S.A.: MICH: Wexford Co.

U.S.A.: Okhlahoma: Latimer Co.

U.S.A.: MO: Pulaski Co.; nr Goslonode R.

New Zealand: AK: Bethells; Matuku Res

U.S.A.: Oklahoma: Latimer Co.

New Zealand: ND: Te Paki; Radar Bush

Chile: Osorno: off Puaucho

Chile: Osorno: Lago Puyehue, off Termas de Puyehue

U.S.A.: CA: Trinity Co., Shasta-Trinity N.F.

U.S.A.: AR: Logan Co.; Mt. Magazine

U.S.A.: AR: Logan Co.; Mt. Magazine Russia: SW Siberia: off Tuva; Kargy R.

Costa Rica: Puntarenas: Monte Verde

Costa Rica: Puntarenas: Monte Verde

Polonia: Spata: Piotrków Tr.

Germany: Rheinland: Bausenberg - Eifel

U.S.A.: AR: Logan Co.; Mt. Magazine 
Colenisia zelandica Leschen $[\& \mathrm{~F}]$

Dermatohomoeus loeblianus Daffner Neohydnobius sp.

Pseudcolenis grandis (Portevin)

Scotocryptini

Zelodes kuscheli Leschen

Aglyptinus laevis (LeConte)

Creagrophorus spinaculeus Wheeler

Cyrtusiola brunnea Švec

Parabystus inquilinus (A. Matthews)

Platypsyllinae -

Leptinillus validus (Horn)

Leptinus testaceus P.W.J. Müller [\&F]

\section{Platypsyllus castoris Ritsema}

Cholevinae

Anemadini Anemadina Anemadus acicularis (Kraatz)

Anemadini Eunemadina Dissochaetus vanini Gnaspini

Eunemadus chilensis Portevin

Nemadotropis stenosoma Szymczakowski

Pseudonemaus (s. str.) cheesmani (Jeannel)

Anemadini Nemadina

Nemadus sp.

Anemadin

Paracatops alacris (Broun)

Paracatopina

Cholevini Catopina

Cholevini Cholevina

Eucatopini

\section{Paracatops antipoda (Kirsch)}

Catops fuliginosus Erichson

Cholevinus fuscipes (Ménétries)

Rybinskiella (s. str.) magnifica (Rybiński)

Sciodrepoides watsoni (Spence)

Catopsimorphus (s. str.) orientalis Aubé

Choleva (s. str.) agilis (Illiger)

Eucatops (Napocatops) giganteus Salgado
New Zealand: (a) ND: Te Paki; (b) AK: Hunua,

Waharau Reserve

India: W Bengal: Darjeeling: Algarah-Labha

Chile: Valdivia: off Panguipulli

Japan: Gifu: off Osaka

New Zealand: Onamahutu Valley, Marlborough

U.S.A.: Okhlahoma: Latimer Co.

Costa Rica: Puntarenas: Monte Verde

Madagascar: off Enacara; Rés. Andohahela

Costa Rica: off Cartago

Canada: Ont: Algonquin Pk

France: Hautes Pyrénées: entrée gr. Lalas (1 male, 1 female)

Suisse: Genéve; La Vessoix (2 specimens, 1 prob. male)

Italy: Basilicata

Brazil: São Paulo: Iporanga

Chile: Osorno: off Puaucho

Chile: Malleco: off Manzanar

Papua New Guinea: Morobe

Czech Republic: Central Bohemia

New Zealand: AK: (a) Lynfield; (b) Duck Creek SR

New Zealand: Auckland Is. (N): Enderby I.

Italy: Friuli Venezia Giulia

Armenia: Kotayk

Ukraine: Zakarpattia Oblast

Italy: Tuscany

Greece: Peloponnese

Italy: Veneto

Ecuador: Napo: off Baeza 


\begin{abstract}
Oritocatopini
Ptomaphagini

Ptomaphagina
\end{abstract}

Ptomaphagini

Ptomaphaginina

Leptodirini

Platycholeina

Leptodirini

Anthroherponina

Leptodirini Leptodirina

Leptodirini Pholeuina

Leptodirini Bathysciina

\section{Sciaphyini}

\section{Outgroups}

Agyrtidae

Agyrtinae
Afrocatops sp.

Adelopsis leo Gnaspini

\section{Amplexella dimorpha Gnaspini}

Parapaulipalpina sp.

Paulipalpina claudicans (Szymczakowski)

Ptomaphagus (Adelops) brevior Jeannel

Ptomaphaminus chapmani (Peck)

Platycholeus opacellus Fall

Anthroherpon hoermanni (Apfelbeck)

\section{Leptomeson leonhardi (Reitter)}

Remyella scaphoides droveniki Giachino \& Etonti

Speoplanes giganteus biocovensis Müller

Boldoria vailatii (Cavadini)

Diaprysius serullazi Peyerimhoff

\section{Troglocharinus (s. str.) ferreri (Reitter)}

Aphaobius milleri (Schmidt)

Orostygia doderoi doderoi Müller

Oryotus schmidti Miller

Sciaphyes sibiricus (Reitter)

Necrophilinae

Pterolomatinae

\section{Agyrtes castaneus (Fabricius)}

Necrophilus hydrophiloides Guérin-Méneville Zeanecrophilus thayerae Newton Apteroloma sp.

Pteroloma forsstromii (Gyllenhal)
South Africa: Natal; off Estcourt

Brazil: São Paulo: Iporanga

Venezuela: Aragua

Venezuela: Bolívar

Brazil: Santa Catarina

U.S.A.: Okhlahoma: Latimer Co.

Malaysia: Sarawak

\section{U.S.A.: CA: Amador Cr., Peddler Hill}

Bosnia and Herzegovina: Sarajevo Canton

Bosnia and Herzegovina

Serbia: Zlatibor

Slovenia: Littoral

Italy: Lombardy

France: Ardeche: grt. des Assiettes

Spain: Catalonia

Italy: Friuli Venezia Giulia

Italy: Veneto

Slovenia: Littoral

Russia: Siberia

Germany: Leipzig - Lützchena

U.S.A.: Washington: Garfield Co.: Lambie Cyn. New Zealand: WN: Tararua Range, Dundas Hut Japan: Hokkaido: Akkeshi, Tokotan Sweden: Granö 
Staphylinidae Tachyporinae Staphylinidae Staphylininae Histeridae
Tachyporus nitidulus (Fabricius)

Philonthus politus (Linnaeus)

Gnathoncus rotundatus (Kugelann)
New Zealand: GB: Pohutu

New Zealand: BR: Lake Rotoit

New Zealand: CO: Earnscleugh 
Table 2. Summary of the main morphological characteristics of male tenent setae among the studied taxa. "\# protarsomeres" and “\# mesotarsomeres" show respectively the presence of MTS on the pro- and mesotarsus of males (the numbers refer to the number of tarsomeres without MTS); "shape" denotes the shape of the MTS (dis = discoidal; con = conical; spt = spatulate; $\min =$ minidiscoidal); "arrangement" denotes the number of longitudinal rows of MTS that can be observed on the tarsomeres. "X" refers to our results and "R" refers to information from the literature that disagree with our data (see also Table 4) - but please note that data from literature may refer to expanded tarsomeres instead of tarsomeres with tenent setae. Taxa marked with ** refer to groups where both males and females allegedelly have tenent setae. Numbers between parentheses after the name of a taxon indicates respectively the number of tarsomeres in male pro- and mesotarsi; if not stated, the taxon has the regular tarsal formula 5-5-5. See text for explanation and discussion.

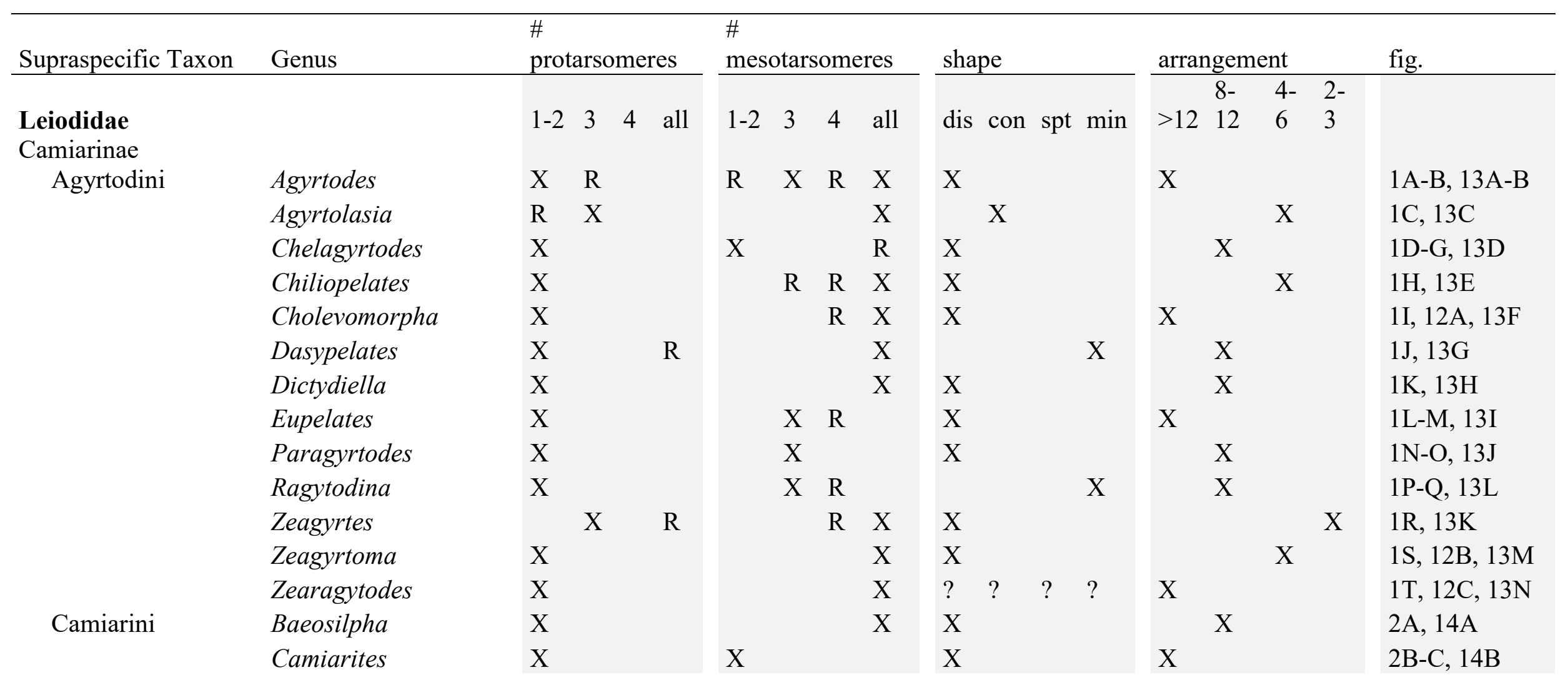




\begin{tabular}{|c|c|c|c|c|c|c|c|c|c|c|c|c|c|c|c|c|}
\hline & Camiarus & $\mathrm{X}$ & & & & & & $\mathrm{X}$ & & & & $\mathrm{X}$ & $\mathrm{X}$ & & & $2 \mathrm{D}, 14 \mathrm{C}$ \\
\hline & Inocatops & $\mathrm{X}$ & & & & & $\mathrm{X}$ & & $\mathrm{X}$ & & & & & $X$ & & $2 \mathrm{E}-\mathrm{F}, 14 \mathrm{D}$ \\
\hline & Neocamiarus & $\mathrm{X}$ & & & & & & $X$ & $X$ & & & & & & $\mathrm{X}$ & $2 \mathrm{G}-\mathrm{H}, 14 \mathrm{E}$ \\
\hline \multirow[t]{4}{*}{ Neopelatopini } & Catopsolius & $X$ & & & & & & $\mathrm{X}$ & $?$ & $?$ & $?$ & $?$ & & $X$ & & $2 \mathrm{~K}, 14 \mathrm{G}$ \\
\hline & Myrmicholeva & $X$ & & & & & $\mathrm{X}$ & & & & & $\mathrm{X}$ & & $X$ & & $2 \mathrm{~N}-\mathrm{O}, 14 \mathrm{I}$ \\
\hline & Neopelatops & $\mathrm{X}$ & $\mathrm{R}$ & & & $X$ & $\mathrm{R}$ & & $\mathrm{X}$ & & & & & $\mathrm{X}$ & & $2 \mathrm{P}-\mathrm{Q}, 14 \mathrm{~J}$ \\
\hline & Sphaeropelatops & $\mathrm{X}$ & & & & & $\mathrm{X}$ & $\mathrm{R}$ & $\mathrm{X}$ & & & & & $X$ & & $2 \mathrm{R}-\mathrm{S}, 14 \mathrm{~K}$ \\
\hline \multicolumn{17}{|l|}{ Catopocerinae } \\
\hline \multirow[t]{2}{*}{ Catopocerini } & Catopocerus & $\mathrm{X}$ & & & $\mathrm{R}$ & $\mathrm{X}$ & & $\mathrm{R}$ & & $\mathrm{X}$ & & & & & $\mathrm{X}$ & $3 \mathrm{~A}-\mathrm{B}, 15 \mathrm{~A}$ \\
\hline & Pinodytes & $\mathrm{X}$ & & & & $X$ & & & & $\mathrm{R}$ & $X$ & & & & $X$ & $3 C-D$ \\
\hline Glacicavicolini & Glacicavicola & $\mathrm{X}$ & & & & & $\mathrm{X}$ & & $\mathrm{X}$ & & & & & $\mathrm{X}$ & & $3 \mathrm{E}-\mathrm{F}, 15 \mathrm{~B}$ \\
\hline Coloninae ${ }^{* *}$ & Colon & $\mathrm{X}$ & & & $\mathrm{R}$ & & & $\mathrm{X}$ & & & & $\mathrm{X}$ & $\mathrm{X}$ & & & $3 \mathrm{G}, 15 \mathrm{C}$ \\
\hline \multicolumn{17}{|l|}{ Leiodinae } \\
\hline \multirow{2}{*}{ Leiodini } & Lionothus & $\mathrm{X}$ & & & & $X$ & & & & $\mathrm{X}$ & & & & & $X$ & $5 \mathrm{G}-\mathrm{H}, 16 \mathrm{E}$ \\
\hline & Zeadolopus & $\mathrm{X}$ & & $\mathrm{R}$ & & $X$ & & $\mathrm{R}$ & & & $X$ & & & & $X$ & $5 \mathrm{I}-\mathrm{J}, 16 \mathrm{~F}$ \\
\hline \multirow[t]{4}{*}{ Sogdini } & Hydnobius & $X$ & & & & $\mathrm{R}$ & $\mathrm{X}$ & & & $\mathrm{X}$ & & & & & $X$ & $4 \mathrm{E}-\mathrm{F}, 16 \mathrm{G}$ \\
\hline & Isocolon & $X$ & & & & $X$ & & & & $X$ & & & & & $X$ & $4 \mathrm{G}-\mathrm{H}, 16 \mathrm{H}$ \\
\hline & Metahydnobius & $X$ & & & & $X$ & & & & $X$ & & & & & $X$ & $4 \mathrm{I}-\mathrm{K}, 16 \mathrm{I}$ \\
\hline & Triarthron & $\mathrm{X}$ & & & & $X$ & & & $X$ & & & & & & $\mathrm{X}$ & $4 \mathrm{~L}-\mathrm{N}, 16 \mathrm{~J}$ \\
\hline \multirow[t]{3}{*}{ Agathidiini } & Agathidium & $X$ & & $\mathrm{R}$ & & $\mathrm{R}$ & $\mathrm{X}$ & $\mathrm{R}$ & $X$ & & & & & $X$ & & $6 \mathrm{~A}-\mathrm{B}, 17 \mathrm{~A}$ \\
\hline & Amphicyllis & $X$ & & & & & $X$ & & & $X$ & & & & $X$ & & $6 C-D, 17 B$ \\
\hline & Anisotoma & $\mathrm{X}$ & $\mathrm{R}$ & & & $X$ & $\mathrm{R}$ & & & & $\mathrm{X}$ & & & $\mathrm{X}$ & & $6 \mathrm{E}-\mathrm{F}, 17 \mathrm{C}$ \\
\hline
\end{tabular}




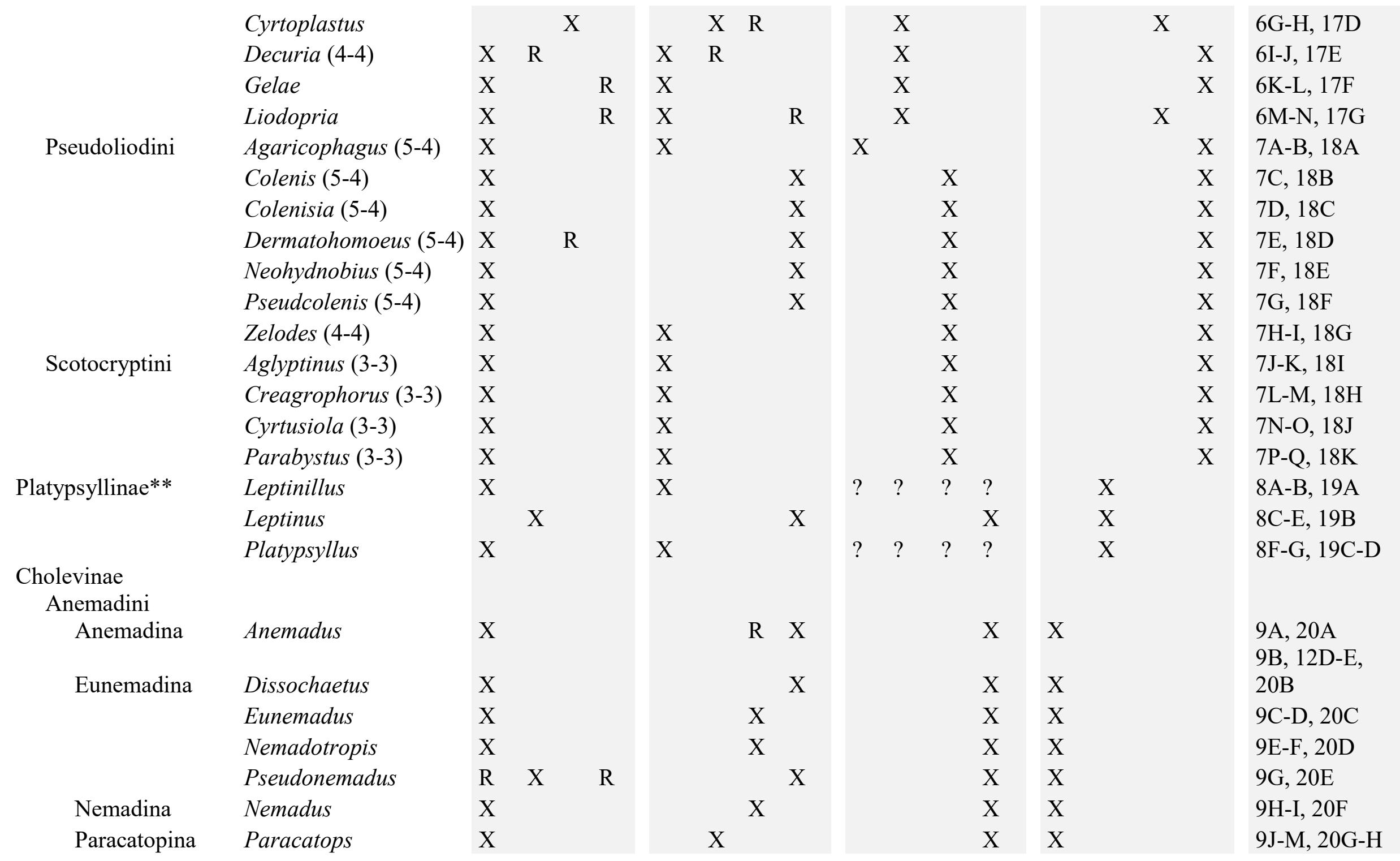




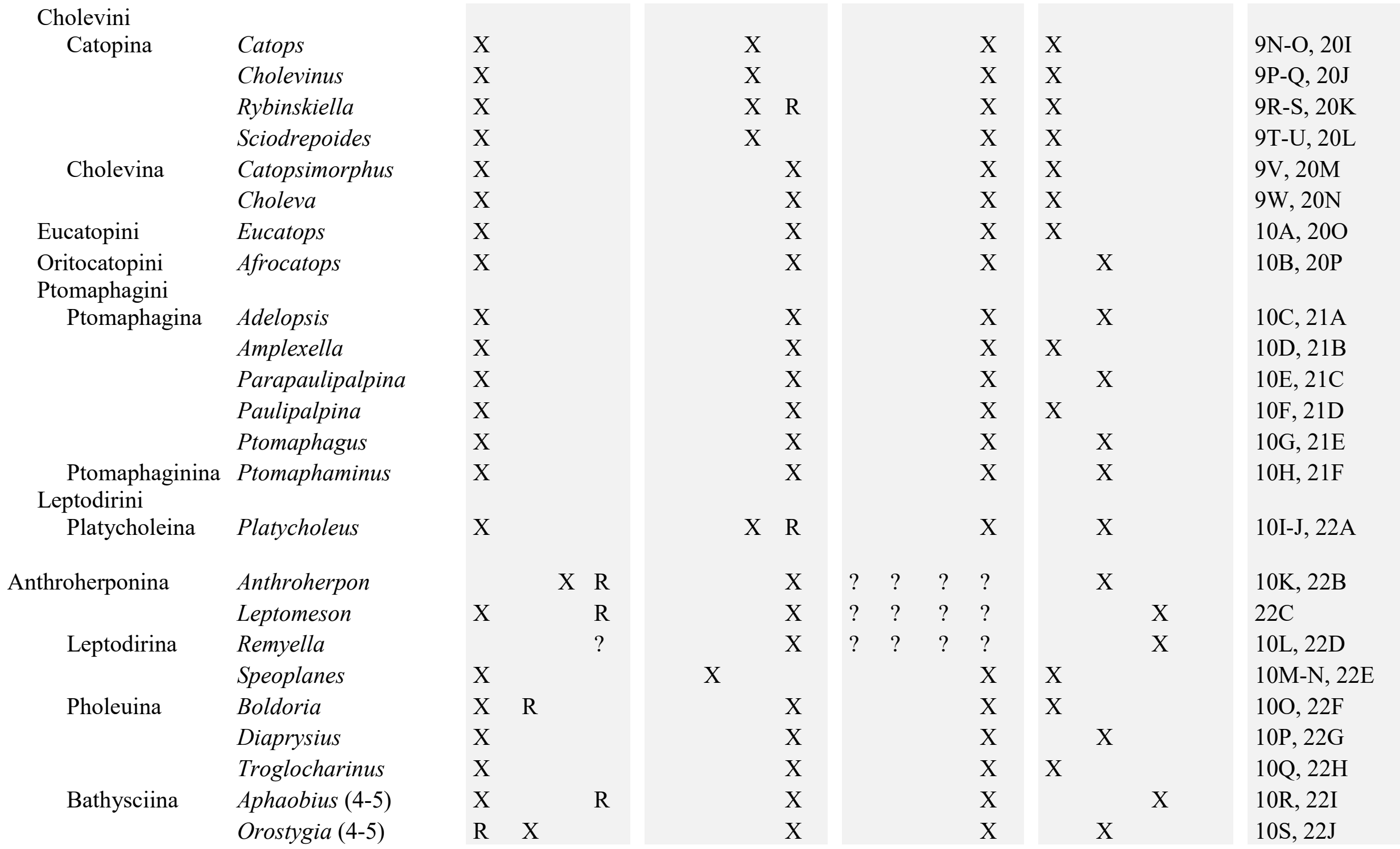




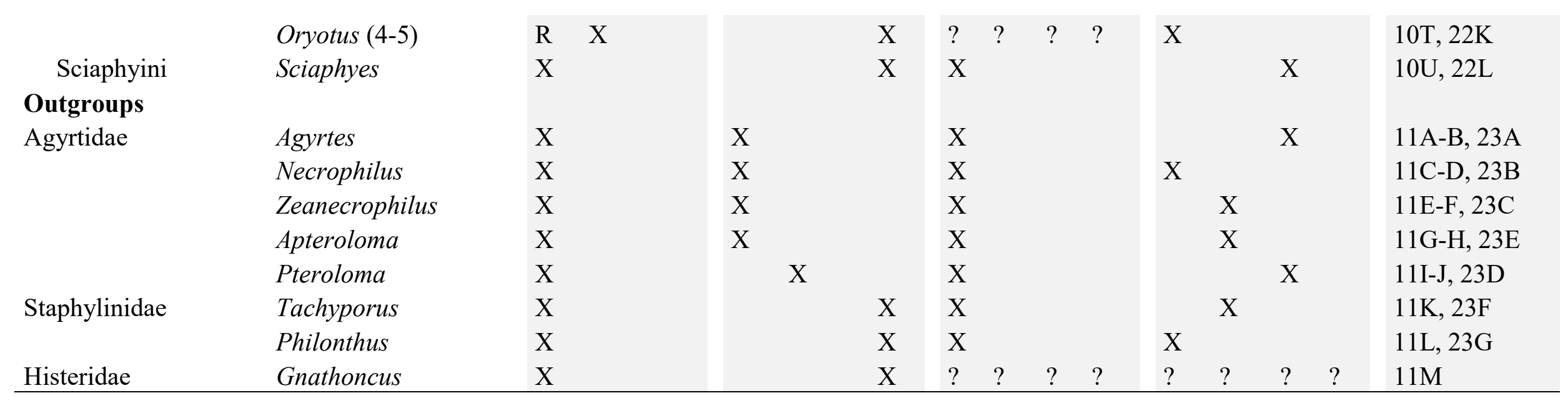


Table 3. Ranges of the numerical values used to establish the different patterns of male tenent setae shape recognized in the present study (see text).

\begin{tabular}{|c|c|c|c|}
\hline Male tenent setae type & ratio length/diameter of the shaft & ratio diameter of shaft tip/base & ratio diameter terminal plate/shaft base \\
\hline discoidal & 7.0 to 17.0 & $\begin{array}{l}\qquad 1.3 \text { to } 2.1 \\
\text { [except the agyrtid Pteroloma, } \\
\text { with a ratio of } 1.2 \text {, and the } \\
\text { undescribed genus of } \\
\text { Neopelatopini, with a ratio of } \\
2.3 \text { ] }\end{array}$ & $\begin{array}{l}\qquad 2.5 \text { to } 3.6 \\
\text { [Camiarites, Triathron, and the agyrtid } \\
\text { Zeanecrophilus a little smaller (2.2-2.3), and } \\
\text { Agyrtodes a little larger (3.9)] }\end{array}$ \\
\hline minidiscoidal & 7.0 to 19.0 & 0.5 to 1.3 & $\begin{array}{l}\qquad 1.2 \text { to } 2.4 \\
\text { [with some larger exceptions in Dasypelates, } \\
\text { Dietta, Adelopsis, Sciaphyes, and the } \\
\text { staphylinid Philonthus and Tachyporus] }\end{array}$ \\
\hline conical & $\begin{array}{l}\qquad 7.0 \text { to } 8.5 \\
\text { [Lionothus has a smaller value (6.0); } \\
\text { Metahydnobius and Isocolon have } \\
\text { larger values }(10.0-12.0)]\end{array}$ & 2.2 to 3.5 & 3.7 to 5.4 \\
\hline spatulate & $\begin{array}{l}3.5 \text { to } 7.0 \\
\text { [Triarthron and Agaricophagus fit this } \\
\text { parameter, but not in the others] }\end{array}$ & $\begin{array}{l}\quad 3.6 \text { to } 5.3 \\
\text { [except for Pinodytes newtoni } \\
\text { (ratio of 1.6), Colenis }(2.1) \text {, and } \\
\text { Colenisia }(2.9) \text { ] }\end{array}$ & 5.4 to 11.0 \\
\hline
\end{tabular}


Table 4. Data from the literature on Leiodidae about "\# protarsomeres" and "\# mesotarsomeres" (respectively the number of non-dilated tarsomeres on the pro- and mesotarsus of males). That data is grouped into subtribes/tribes (or groups of genera within subtribes/tribes if the data are polymorphic) with the same pattern. When the reference does not state number but only the presence of dilated tarsomeres, we used the numbers stated by other reference in the same genus/subtribe/tribe. Numbers between parentheses after the name of a taxon indicates respectively the number of tarsomeres in male pro- and mesotarsi. Columns are marked "?" when the reference states the presence of dilated tarsomeres but does not inform the number. The term "fig" after a reference indicates that the information was taken from a figure, and it is not stated in the text. The same reasoning applies to the terms "key" and "matrix".

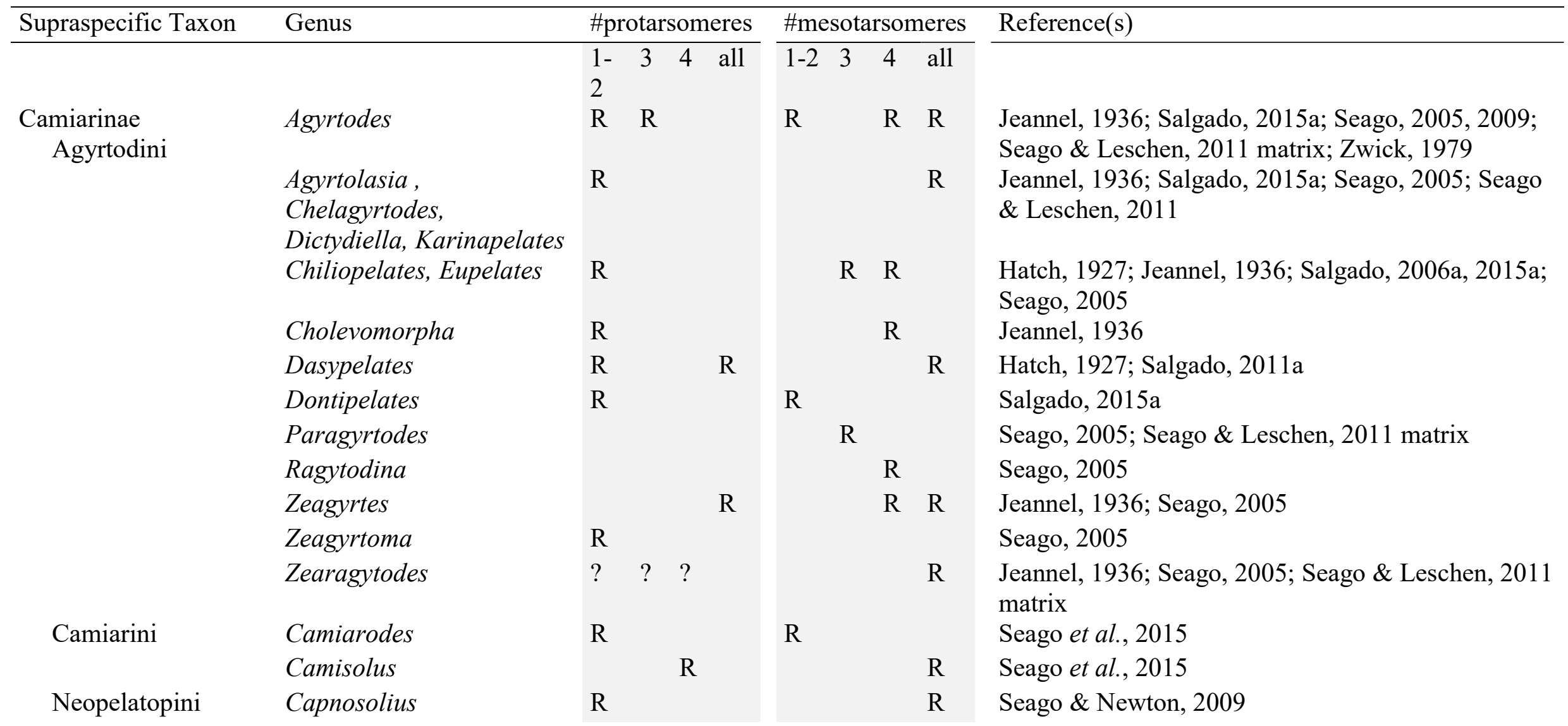




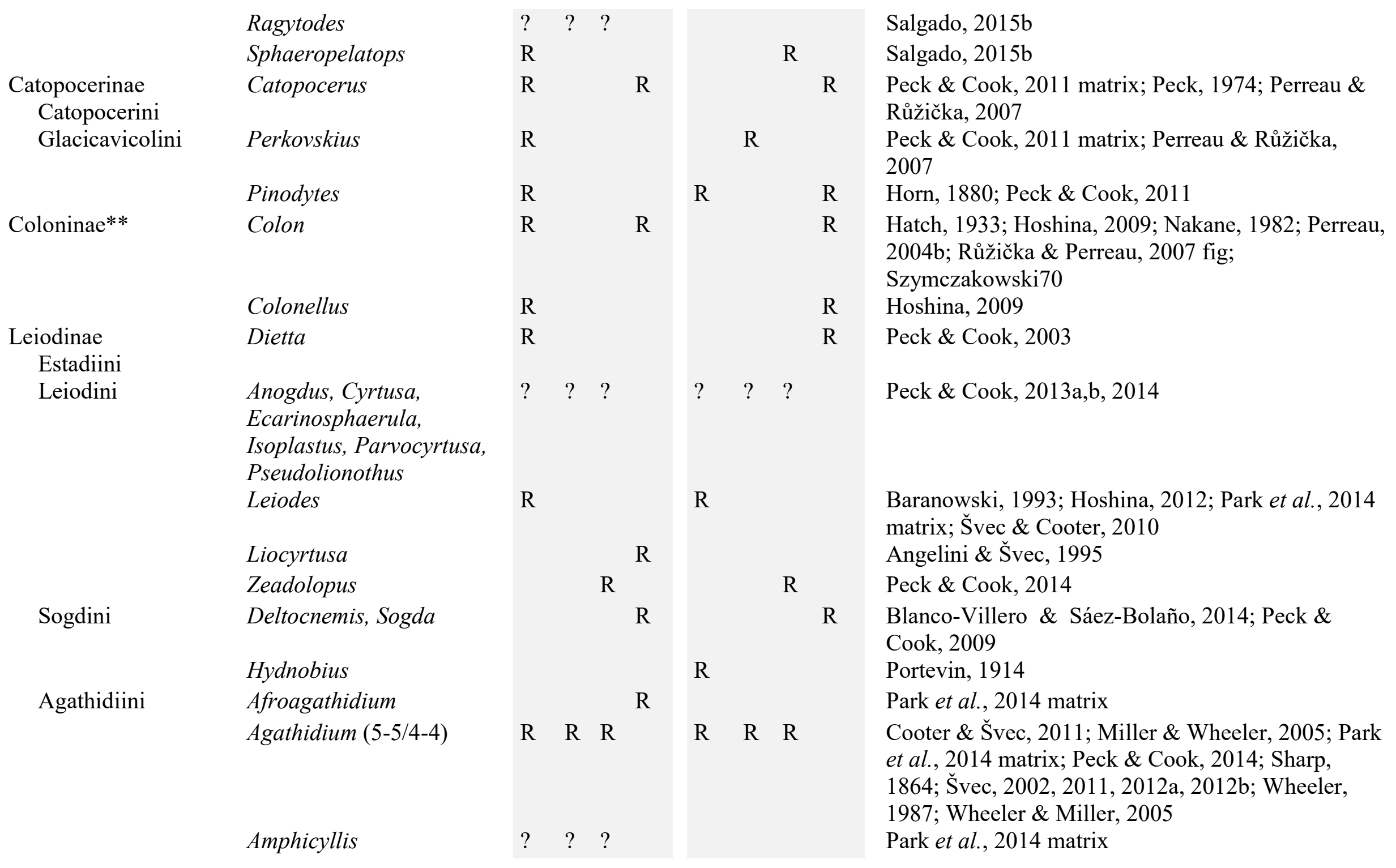




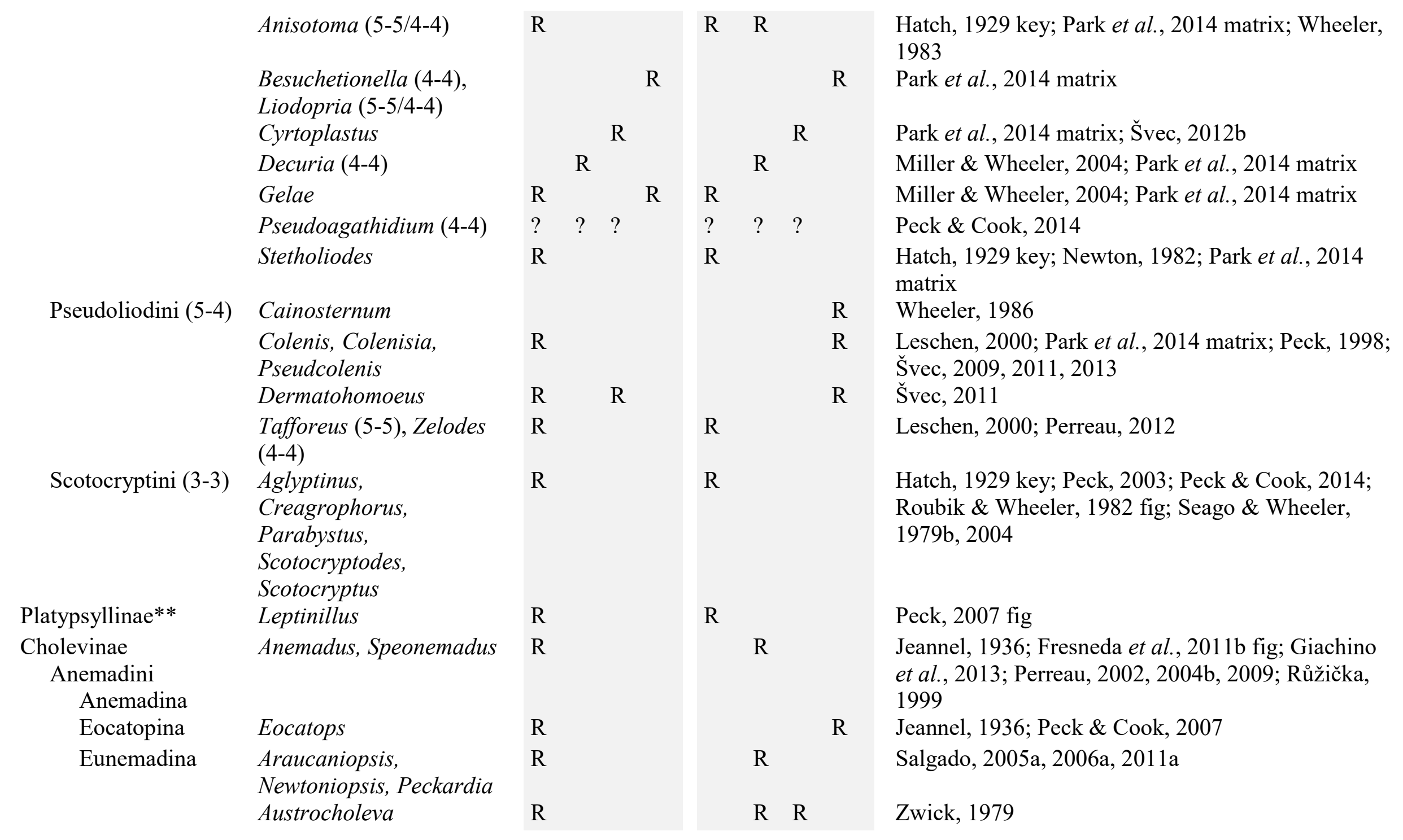


Austronargus, Eunemadus,

Falkocholeva,

Falkonemadus,

Nemadiopsis,

Nemadotropis

Austronemadus,

Dissochaetus,

Nargomorphus,

Nemadiolus,

Pseudonargiotes, Rangiola Catoposchema, Nargiotes

Pseudonemadus

Nemadina

Micronemadus, Nemadus

Paracatopina

Cholevini

Catopina

Cholevina

\section{Mesocolon, Paracatops} Apocatops, Catopidius,

Catops, Catoptrichus,

Chionocatops, Cholevinus, Dreposcia, Dzungarites,

Fissocatops, Sciodrepoides Catopodes, Mesocatops

Rybinskiella

Attaephilus

Attumbra,

Catopsimorphus, Choleva,

Nargus, Prionochaeta,

Takobiella

Philomessor

\section{$\mathrm{R}$}

\section{s}

\section{$\mathrm{R}$}

$\mathrm{R}$

$\mathrm{R}$$$
\mathrm{R}
$$

$\mathrm{R}$
Jeannel, 1936; Perreau, 2002; Salgado, 2002, 2005a, 2006a, 2011a,b; Zwick, 1979

$\mathrm{R}$

Jeannel, 1936; Hatch, 1933 key; Gnaspini, 1991; Salgado, 2000, 2005a, 2006b; Zwick, 1979

R R Jeannel, 1936; Salgado, 2005a-cit; Zwick, 1979 R Jeannel, 1936; Zwick, 1979

R R Jeannel, 1936; Hatch, 1933 key; Fall, 1937; Peck \& Cook, 2007; Perreau, 2004; Perreau \& Tafforeau, 2011; Fresneda et al., 2011b matrix

$\mathrm{R}$

R Jeannel, 1936; Blas \& Borges, 1999; Fresneda et al., 2011 b fig; Nakane, 1982; Hatch, 1933 \& key; Horn, 1880; Peck \& Skeley, 2001; Peck \& Cook, 2002; Perreau, 2002, 2012; Perreau \& Perkovsky, 2015; Růžička \& Perreau, 2011; Szymczakowski, 1975 Jeannel, 1936; Perreau, 2002

\section{R R Jeannel, 1936}

$\mathrm{R}$

R Hatch, 1933 key; Giachino, 1988; Jeannel, 1936; Peck, 1977; Peck \& Cook, 2002; Perreau, 2004a; Schilthuizen, 1990 fig; Salgado et al., 2003; Szymczakowski, 1975; Vávra, 2015a; Wang et al., 2015

R R Vávra, 2015b 


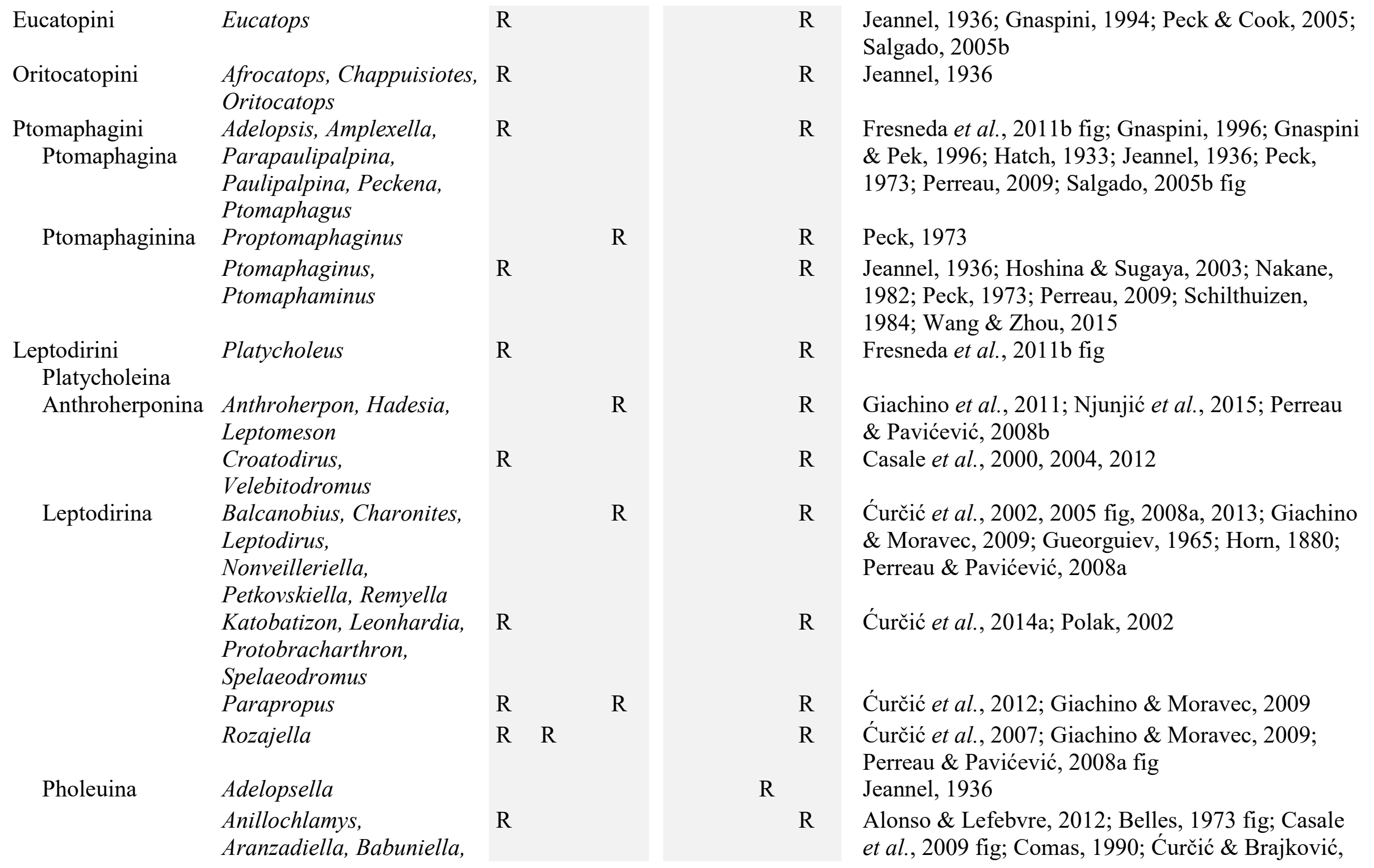




\section{Baronniesia}

Cantabrogeus,

Ceuthophyes, Cytodromus,

Espanoliella,

Fresnedaella,

Gueorguievella,

Insubriella, Magdelainella,

Monguzziella, Nafarroa,

Patriziella,

Phacomorphus, Pholeuon,

Quaestus, Speonomus,

Stygiophyes,

Troglocharinus

Bathysciola, Drimeotus

Bellesia, Beronia,

Beskovia,

Paranillochlamys,

Perriniella, Rhodopiola

Boldoria, Radevia

Paratroglophyes,

Pseudospeonomus

Spelaeochlamys

Bathysciina (4-5) Aphaobiella, Aphaobius, Blattochaeta, Epiroella, Henrotiella, Hexaurus, Lotharia, Phaneropella, Pholeuonopsis, Speophyes
2002; Ćurčić et al., 2004, 2005 fig, 2009; Faille et al., 2009 fig; Fresneda \& Dupré, 2010; Fresneda \& Escolà, 2000 fig; Fresneda \& Hernando 1988 fig,90 fig, 1991 fig, 1994b fig; Fresneda \& Salgado, 2001; Fresneda et al., 2007 fig, 2009; Giachino \&

Gueorguiev, 2006; Gueorguiev, 2007; Moldovan et al., 2007; Rizzo \& Comas, 2015 fig; Salgado, 1999; Salgado \& Fresneda, 2003, 2004, 2005, 2006, 2010; Salgado et al., 2010 , 2011, 2012; Vailati, 1990, 1993
$\mathrm{R}$

$\mathrm{R}$

$? ? ?$

R $\quad \mathrm{R}$

$\mathrm{R}$

$\mathrm{R} \quad \mathrm{R}$

$\mathrm{R}$
$\mathrm{R}$

R Giachino \& Gueorguiev 1996; Vailati, 1973, 1974

$\mathrm{R}$

$\mathrm{R}$

$\mathrm{R}$ Giachino, 1998; Latella, 2002, 2012, \& Rampini, 1994; Moldovan, 2000 2008; Perreau \& Tronquet, 2002; Salgado \& Fresneda, 2003

Fresneda et al., 2011a; Salgado \& Fresneda, 2003 Fresneda, 2003
Fresneda et al., 2010; Fresneda \& Bourdeau, 2012;

Fresneda \& Hernando94a; Giachino \& Gueorguiev,

Comas 1977, 1978 (as Typhlochlamys); Salgado \&

Alonso \& Lefebvre, 2013; Casale et al., 1991, 2013; Ćurčić et al., 2006, 2014b; Giachino \& Gueorguiev, 2008; Gueorguiev, 2007; Perreau, 2003 key, 2010; Polak \& Jalžić, 2009 
Cansiliella, Orostygia,

Oryotus, Pretneria

Serboleonhardella,

Bathysciotina (4- Bathyscidius, Pavicevicia

5)

(4-5)

Spelaeobatina

Prospelaeobates

Sciaphyes
Sciaphyini
$\mathrm{R}$

$\mathrm{R}$

$\mathrm{R}$

$\mathrm{R}$

$\mathrm{R}$
R Bognolo \& Kofler, 2001; Etonti, 2001; Paoletti, 1972; Perreau, 2003; Piva, 2005; Vailati, 1995

Ćurčić et al., 2008b

Giachino, 2006; Perreau, 2008

Polak \& Bognolo, 2003

Hoshina \& Perreau, 2008 fig; Fresneda et al., $2011 \mathrm{~b}$ 


\section{Figure Legends}

Fig. 1. Pro- and mesotarsi (abbreviated "p" and "m") of males, showing expanded tarsomere and the presence of male tenent setae. All left legs, except when noted. Camiarinae Agyrtodini. A-B, Agyrtodes ovatus (p\&m); C, Agyrtolasia calliptera (p); D-E, Chelagyrtodes crowsoni (p\&m); F-G, Chelagyrtodes davidi (p\&m, right leg); H, Chiliopelates pictus (p); I, Cholevomorpha picta (p); J, Dasypelates sp. (p); K, Dictydiella turneri (p); L-M, Eupelates transversestrigosus (p\&m); N-O, Paragyrtodes candens (p\&m); P-Q, Ragytodina tuberculosa (p\&m); R, Zeagyrtes vitticollis (p, right leg); S, Zeagyrtoma undulata (p); T, Zearagytodes concinnus (p). Scale $50 \mu \mathrm{m}$.

Fig. 2. Pro- and mesotarsi (abbreviated "p" and "m") of males, showing expanded tarsomere and the presence of male tenent setae. All left legs, except when noted. Camiarinae Camiarini and Neopelatopini. A, Baeosilpha rufescens (p); B-C, Camiarites convexus (p\&m); D, Camiarus thoracicus (p); E-F, Inocatops concinnus (p\&m); G-H, Neocamiarus kuscheli (p\&m); I-J, Undescribed Genus sp. b. (p\&m); K, Catopsolius laevicollis (p); L-M, Eublackburniella extranea (p\&m); N-O, Myrmicholeva sp. (p\&m); P-Q, Neopelatops edwardsi (p\&m); R-S, Sphaeropelatops pilosus (p\&m). Scale $50 \mu \mathrm{m}$.

Fig. 3. Pro- and mesotarsi (abbreviated "p" and "m") of males, showing expanded tarsomere and the presence of male tenent setae. All left legs, except when noted. Catopocerinae and Coloninae. A-B, Catopocerus politus (p\&m); C-D, Pinodytes newtoni (p\&m); E-F, Glacicavicola bathyscioides (p\&m); $3 \mathrm{G}$, Colon hirtale (p). Scale $50 \mu \mathrm{m}$.

Fig. 4. Pro- and mesotarsi (abbreviated "p" and "m") of males, showing expanded tarsomere and the presence of male tenent setae. All left legs, except when noted. Leiodinae Estadiini and Sogdini. A-B, Dietta huanuco (p\&m); C-D, Dietta sp. (p\&m [with 4 tarsomeres, and no MTS]); E-F, Hydnobius sp. (p\&m); G-H, Isocolon hilare (p\&m); I-K, Metahydnobius bicolor (p\&m \&metatarsus); L-N, Triarthron lecontei (p\&m \&metatarsus). Scale $50 \mu \mathrm{m}$.

Fig. 5. Pro- and mesotarsi (abbreviated "p" and "m") of males, showing expanded tarsomere and the presence of male tenent setae. All left legs, except when noted. Leiodinae Leiodini. A-B, Anogdus sp. (p\&m); C-D, Isoplastus fossor (p\&m); E-F, Leiodes sp. (p\&m); G-H, Lionothus ulkei (p\&m); I-J, Zeadolopus spinipes (p\&m). Scale $50 \mu \mathrm{m}$.

Fig. 6. Pro- and mesotarsi (abbreviated "p" and "m") of males, showing expanded tarsomere and the presence of male tenent setae. All left legs, except when noted. Leiodinae Agathidiini. A-B, Agathidium oniscoides (p\&m); C-D, Amphicyllis globus (p\&m); E-F, Anisotoma discolor (p\&m) (the numbers show the number of longitudinal rows of MTS); G-H, Cyrtoplastus sp. (p\&m); I-J, Decuria newtoni (p\&m); K-L, Gelae sp. (p\&m); M-N, Liodopria serricornis (p\&m). Scale $50 \mu \mathrm{m}$.

Fig. 7. Pro- and mesotarsi (abbreviated "p" and "m") of males, showing expanded tarsomere and the presence of male tenent setae. All left legs, except when noted. Leiodinae Pseudoliodini and Scotocryptini. A-B, Agaricophagus cephalotes (p\&m); C, Colenis ora (p); D, Colenisia zelandica (p); E, Dermatohomoeus loeblianus (p); F, Neohydnobius sp. (p); G, Pseudcolenis grandis (p); H-I, Zelodes kuscheli (p\&m); J-K, Aglyptinus laevis (p\&m); L-M, Creagrophorus spinaculeus (p\&m); N$\mathrm{O}$, Cyrtusiola brunnea (p\&m); P-Q, Parabystus inquilinus (p\&m). Scale $50 \mu \mathrm{m}$.

Fig. 8. Pro- and mesotarsi (abbreviated "p" and "m") of males, showing expanded tarsomere and the presence of male tenent setae. All left legs, except when noted. Platypsyllinae. A-B, Leptinillus validus 
(p\&m); C-E, Leptinus testaceus (p\&m, and female p); F-G, Platypsyllus castoris (p, right leg; m, other specimen, sex ?). Scale $50 \mu \mathrm{m}$.

Fig. 9. Pro- and mesotarsi (abbreviated "p" and "m") of males, showing expanded tarsomere and the presence of male tenent setae. All left legs, except when noted. Cholevinae Anemadini and Cholevini. A, Anemadus acicularis (p); B, Dissochaetus vanini (p); C-D, Eunemadus chilensis (p\&m); E-F, Nemadotropis stenosoma (p\&m); G, Pseudonemaus cheesmani (p); H-I, Nemadus sp. (p\&m); J-K, Paracatops alacris (p\&m); L-M, Paracatops antipoda (p\&m); N-O, Catops fuliginosus (p\&m); P-Q, Cholevinus fuscipes (p\&m); R-S, Rybinskiella magnifica (p\&m); T-U, Sciodrepoides watsoni (p\&m); $\mathrm{V}$, Catopsimorphus orientalis (p); W, Choleva agilis (p). Scale $50 \mu \mathrm{m}$.

Fig. 10. Pro- and mesotarsi (abbreviated " $p$ " and " $m$ ") of males, showing expanded tarsomere and the presence of male tenent setae. All left legs, except when noted. Cholevinae Eucatopini, Oritocatopini, Ptomaphagini, Leptodirini, and Sciaphyini. A, Eucatops giganteus (p); B, Afrocatops sp. (p); C, Adelopsis leo (p); D, Amplexella dimorpha (p); E, Parapaulipalpina sp. (p); F, Paulipalpina claudicans (p); G, Ptomaphagus brevior (p); H, Ptomaphaminus chapmani (p); I-J, Platycholeus opacellus (p\&m); K, Anthroherpon hoermanni (p); L, Remyella scaphoides droveniki (p); M-N, Speoplanes giganteus biocovensis (p\&m); O, Boldoria vailatii (p); P, Diaprysius serullazi (p); Q, Troglocharinus ferreri (p); R, Aphaobius milleri (p); S, Orostygia doderoi doderoi (p); T, Oryotus schmidti (p); U, Sciaphyes sibiricus (p). Scale $50 \mu \mathrm{m}$.

Fig. 11. Pro- and mesotarsi (abbreviated " $p$ " and "m") of males, showing expanded tarsomere and the presence of male tenent setae. All left legs, except when noted. Outgroups - Agyrtidae, Staphylinidae, and Histeridae. A-B, Agyrtes castaneus (p\&m); C-D, Necrophilus hydrophiloides (p\&m); E-F, Zeanecrophilus thayerae (p\&m); G-H, Apteroloma sp. (p\&m); I-J, Pteroloma forsstromii (p\&m); K, Tachyporus nitidulus (p); L, Philonthus politus (p); M, Gnathoncus rotundatus (p). Scale $50 \mu \mathrm{m}$.

Fig. 12. Mesotarsi of males with atypical armature (see text for discussion). All left legs. A. Cholevomorpha picta; B. Zeagyrtoma undulata; C. Zearagytodes concinnus; D-E, Dissochaetus vanini. Scale $50 \mu \mathrm{m}$.

Fig. 13. Detail of male tenent setae on the first protarsomere of males. All left legs, except when noted. Camiarinae Agyrtodini. A, Agyrtodes monticola; B, Agyrtodes ovatus; C, Agyrtolasia calliptera; D, Chelagyrtodes davidi (right leg); E, Chiliopelates pictus; F, Cholevomorpha picta; G, Dasypelates sp.; H, Dictydiella turneri; I, Eupelates transversestrigosus; J, Paragyrtodes candens; K, Ragytodina tuberculosa; L, Zeagyrtes vitticollis (right leg); 13M, Zeagyrtoma undulata; N, Zearagytodes concinnus. The arrow indicates a notch (see text). Scale $20 \mu \mathrm{m}$.

Fig. 14. Detail of male tenent setae on the first protarsomere of males. All left legs, except when noted. Camiarinae Camiarini and Neopelatopini. A, Baeosilpha rufescens; B, Camiarites convexus; C, Camiarus thoracicus; D, Inocatops concinnus; E, Neocamiarus kuscheli; F, Undescribed Genus sp. b.; G, Catopsolius laevicollis; H, Eublackburniella extranea; I, Myrmicholeva sp.; J, Neopelatops edwardsi; K, Sphaeropelatops pilosus. The arrow indicates a notch (see text). Scale $20 \mu \mathrm{m}$.

Fig. 15. Detail of male tenent setae on the first protarsomere of males. All left legs, except when noted. Catopocerinae and Coloninae. A, Catopocerus politus; B, Glacicavicola bathyscioides; C, Colon hirtale. Scale $20 \mu \mathrm{m}$.

Fig. 16. Detail of male tenent setae on the first protarsomere of males. All left legs, except when noted. Leiodinae Estadiini, Leiodini, and Sogdini. A, Dietta sp.; B, Anogdus sp.; C, Isoplastus fossor; D, 
Leiodes sp.; E, Lionothus ulkei; F, Zeadolopus spinipes; G, Hydnobius sp.; H, Isocolon hilare; I, Metahydnobius bicolor; J, Triarthron lecontei. Scale $20 \mu \mathrm{m}$.

Fig. 17. Detail of male tenent setae on the first protarsomere of males. All left legs, except when noted. Leiodinae Agathidiini. A, Agathidium oniscoides; B, Amphicyllis globus; C, Anisotoma discolor; D, Cyrtoplastus sp.; E, Decuria newtoni; F, Gelae sp.; G, Liodopria serricornis. The arrow indicates a notch (see text). Scale $20 \mu \mathrm{m}$.

Fig. 18. Detail of male tenent setae on the first protarsomere of males. All left legs, except when noted. Leiodinae Pseudoliodini and Scotocryptini. A, Agaricophagus cephalotes; B, Colenis ora; C, Colenisia zelandica; D, Dermatohomoeus loeblianus; E, Neohydnobius sp.; F, Pseudcolenis grandis; G, Zelodes kuscheli; H, Creagrophorus spinaculeus; I, Aglyptinus laevis; J, Cyrtusiola brunnea; K, Parabystus inquilinus. The arrow indicates a notch (see text). Scale $20 \mu \mathrm{m}$.

Fig. 19. Detail of male tenent setae on the first protarsomere of males. All left legs, except when noted. Platypsyllinae. A, Leptinillus validus; B, Leptinus testaceus; C-D, Platypsyllus castoris (C, right leg; $\mathrm{D}, 4^{\text {th }}$ tarsomere). Scale $20 \mu \mathrm{m}$. Scale $20 \mu \mathrm{m}$.

Fig. 20. Detail of male tenent setae on the first protarsomere of males. All left legs, except when noted. Cholevinae Anemadini, Cholevini, Eucatopini, and Oritocatopini. A, Anemadus acicularis; B, Dissochaetus vanini; C, Eunemadus chilensis; D, Nemadotropis stenosoma; E, Pseudonemaus cheesmani; F, Nemadus sp.; G, Paracatops alacris; H, Paracatops antipoda; I, Catops fuliginosus; J, Cholevinus fuscipes; K, Rybinskiella magnifica; L, Sciodrepoides watsoni; M, Catopsimorphus orientalis; N, Choleva agilis; O, Eucatops giganteus; P, Afrocatops sp. Scale $20 \mu \mathrm{m}$.

Fig. 21. Detail of male tenent setae on the first protarsomere of males. All left legs, except when noted. Cholevinae Ptomaphagini. A, Adelopsis leo; B, Amplexella dimorpha; C, Parapaulipalpina sp.; D, Paulipalpina claudicans; E, Ptomaphagus brevior; F, Ptomaphaminus chapmani. The arrow indicates a notch (see text). Scale $20 \mu \mathrm{m}$.

Fig. 22. Detail of male tenent setae on the first protarsomere of males. All left legs, except when noted. Cholevinae Leptodirini and Sciaphyini. A, Platycholeus opacellus; B, Anthroherpon hoermanni; C, Leptomeson leonhardi; D, Remyella scaphoides droveniki; E, Speoplanes giganteus biocovensis; F, Boldoria vailatii; G, Diaprysius serullazi; H, Troglocharinus ferreri; I, Aphaobius milleri; J, Orostygia doderoi doderoi; K, Oryotus schmidti; L, Sciaphyes sibiricus. Scale $20 \mu \mathrm{m}$.

Fig. 23. Detail of male tenent setae on the first protarsomere of males. All left legs, except when noted. Outgroups - Agyrtidae and Staphylinidae. A, Agyrtes castaneus; B, Necrophilus hydrophiloides; C, Zeanecrophilus thayerae; D, Pteroloma forsstromii; E, Apteroloma sp.; F, Tachyporus nitidulus; G, Philonthus politus. Scale $20 \mu \mathrm{m}$.

Fig. 24. Tentative transformation series in the shape of the male tenent setae in leiodid beetles (see text for discussion). A, typical discoidal type; B. minidiscoidal type (typical of Cholevinae in general); C. discoidal type typical of some Ptomaphagini cholevines; D. conical type (typical of Leiodinae in general, except for Estadiini); E. spatulate type (typical of Pseudoliodini+Scotocryptini leiodines); F. Zearagytodes type; G. Catopsolius \& Anthroherponina type. Scale $50 \mu \mathrm{m}$. 


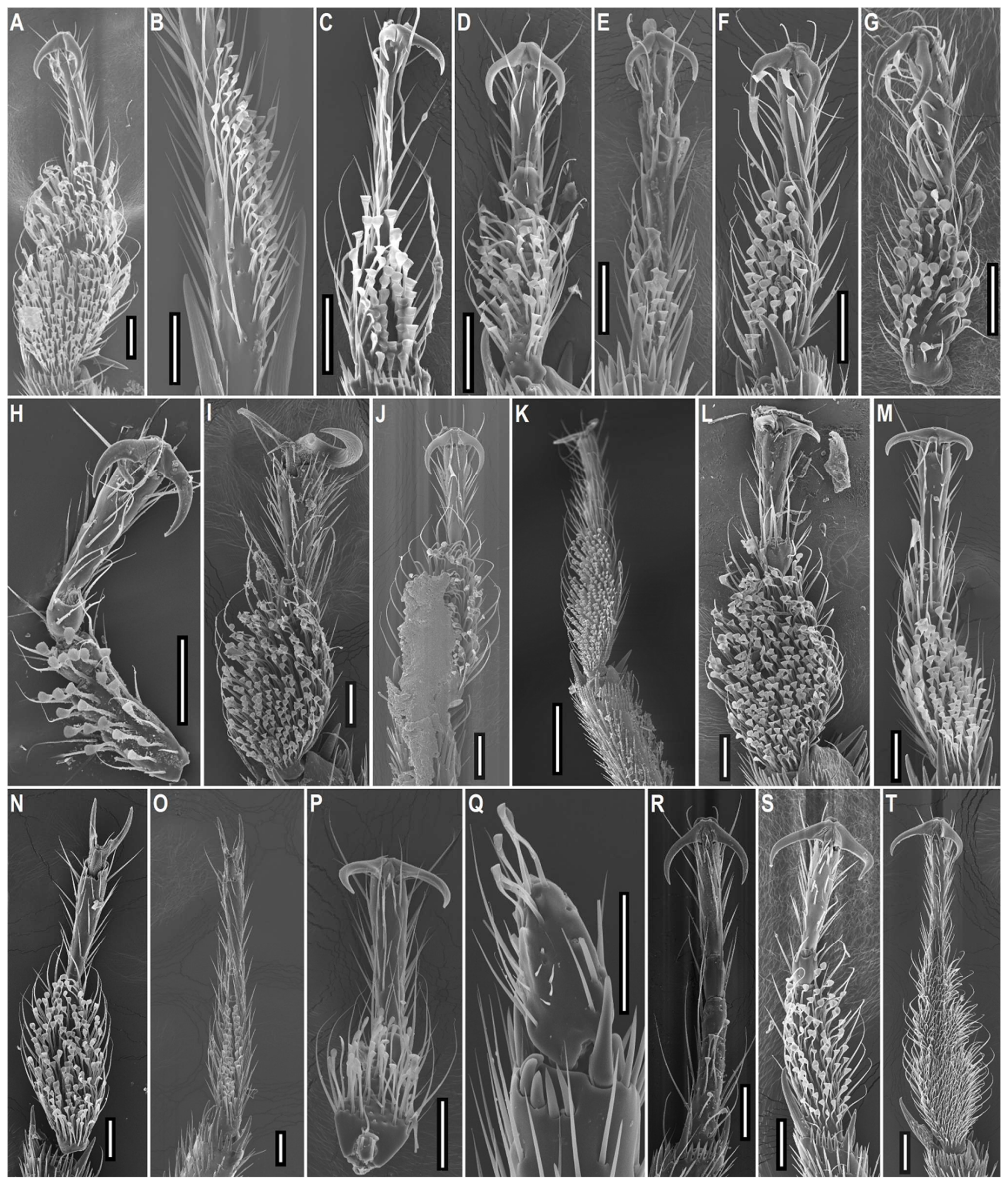

Fig. 1 


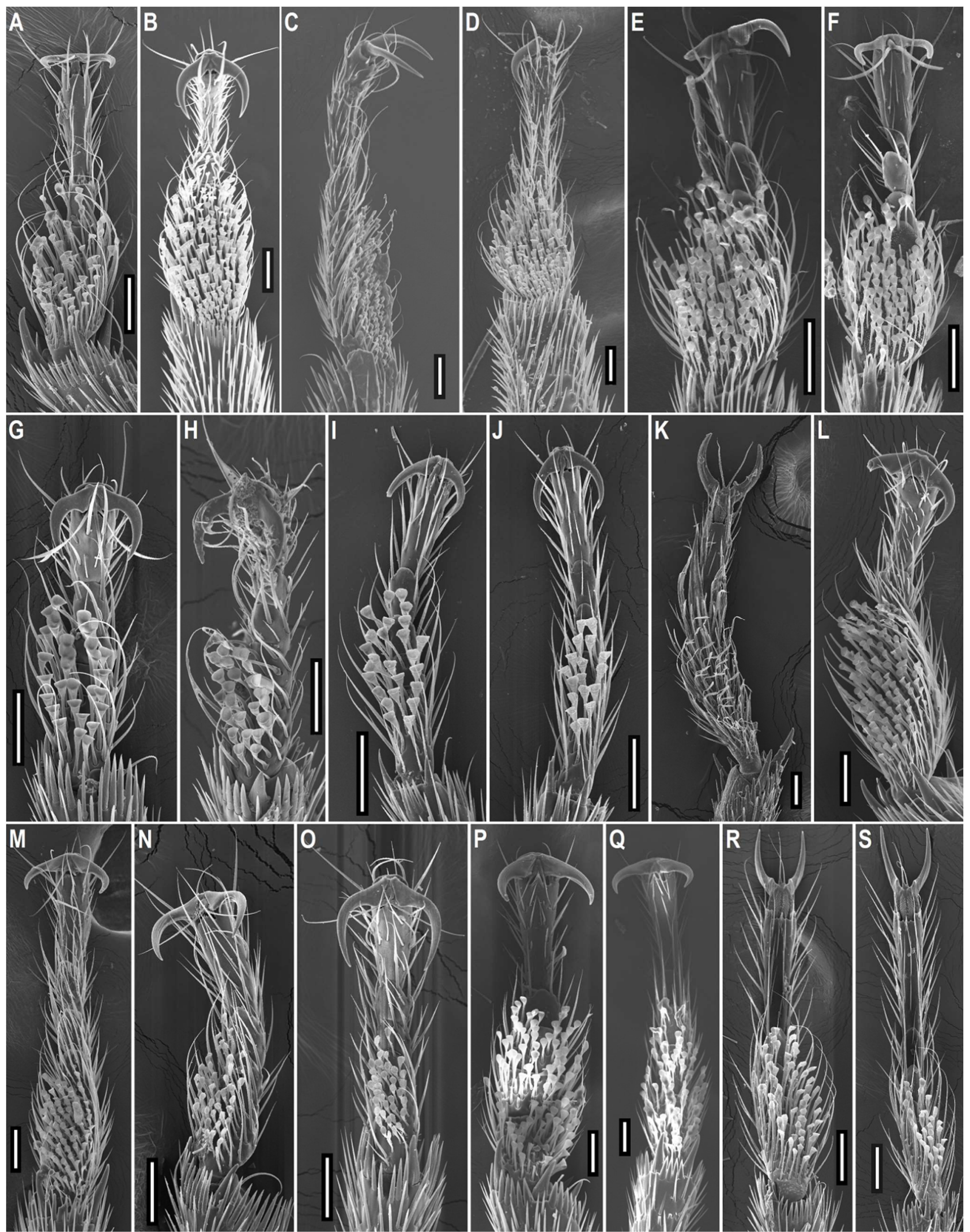

Fig. 2 
CAPÍTULO 4

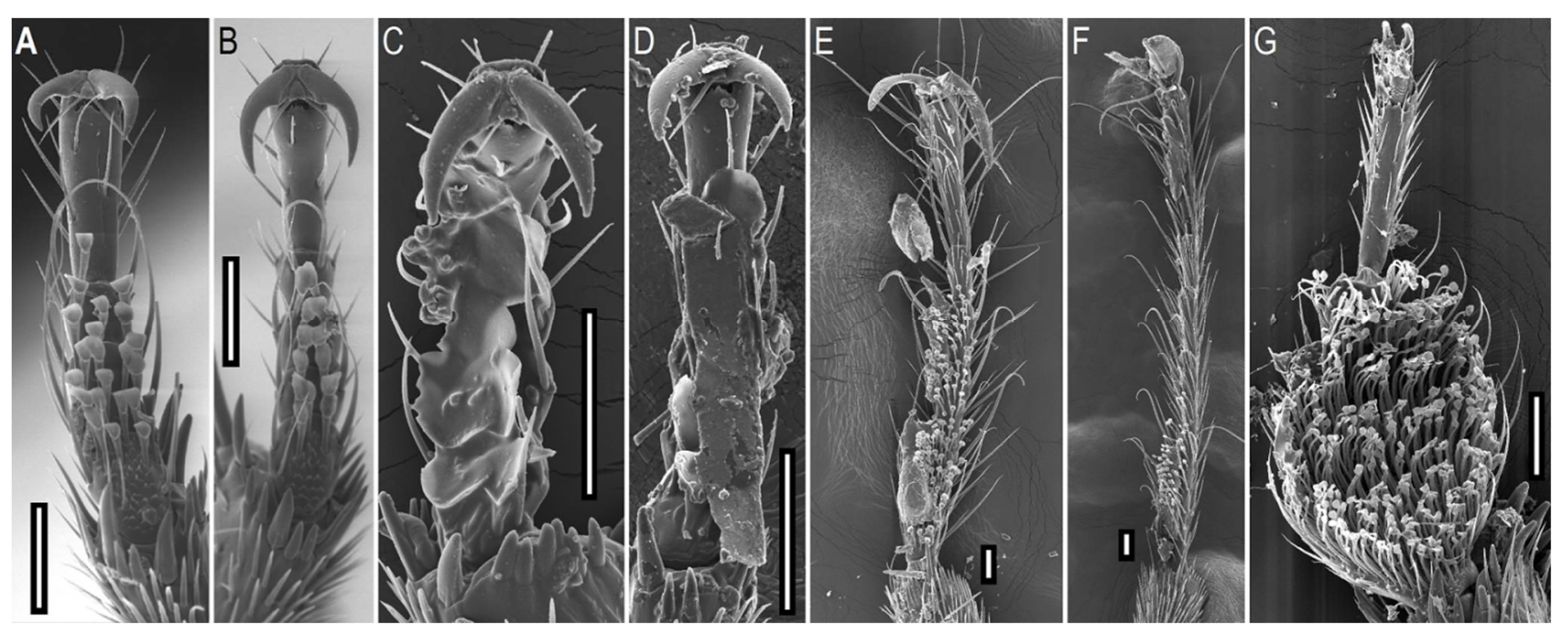

Fig. 3 


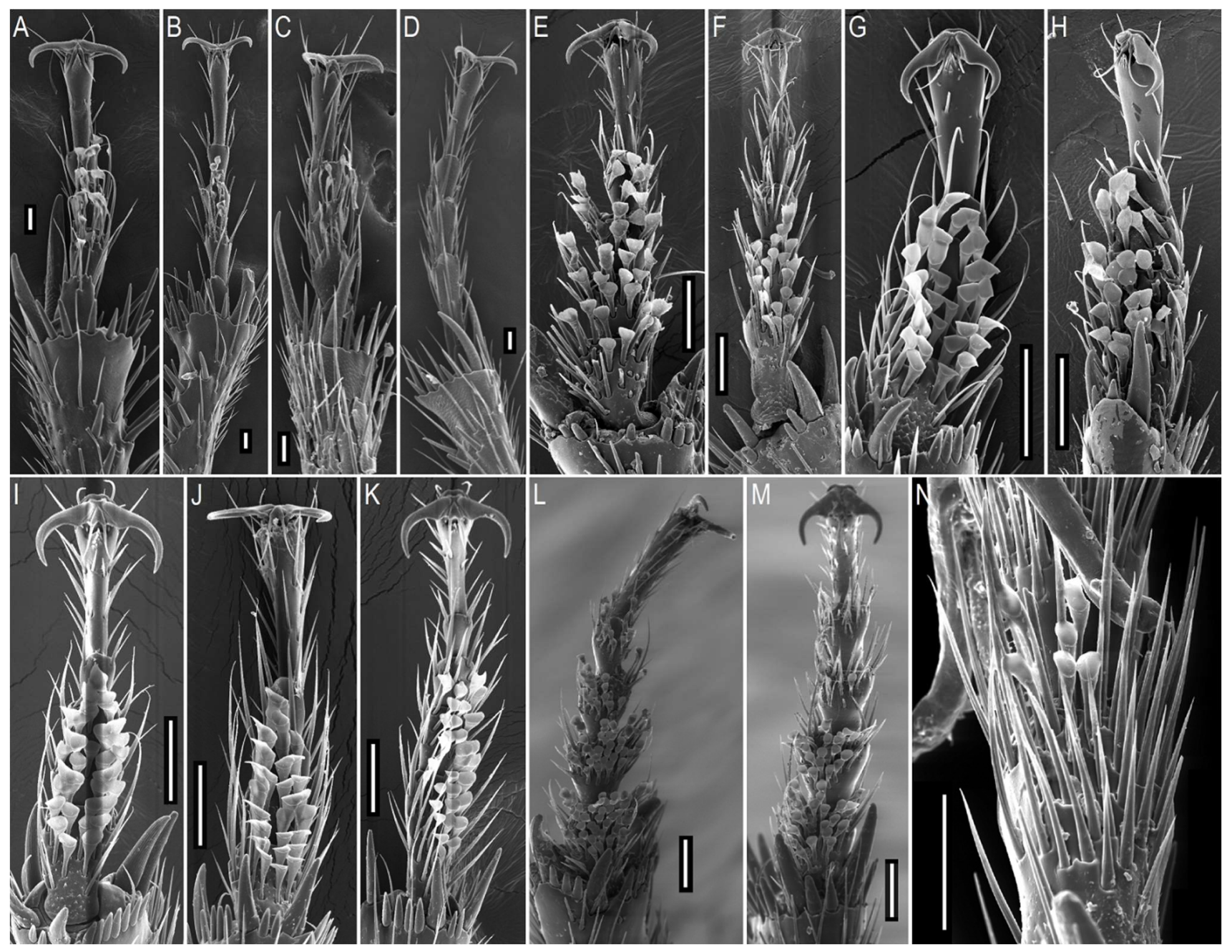

Fig. 4 


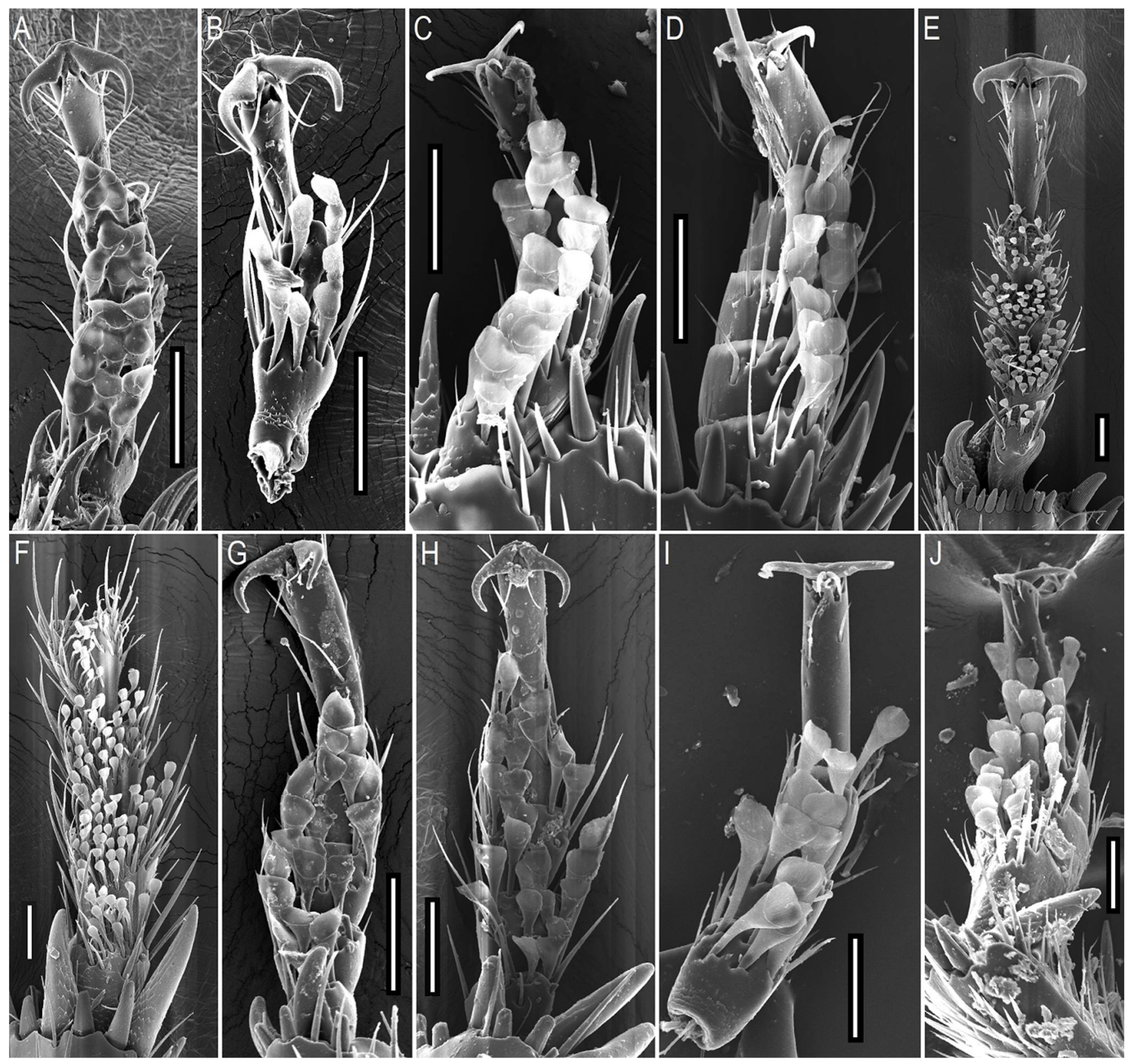

Fig. 5 

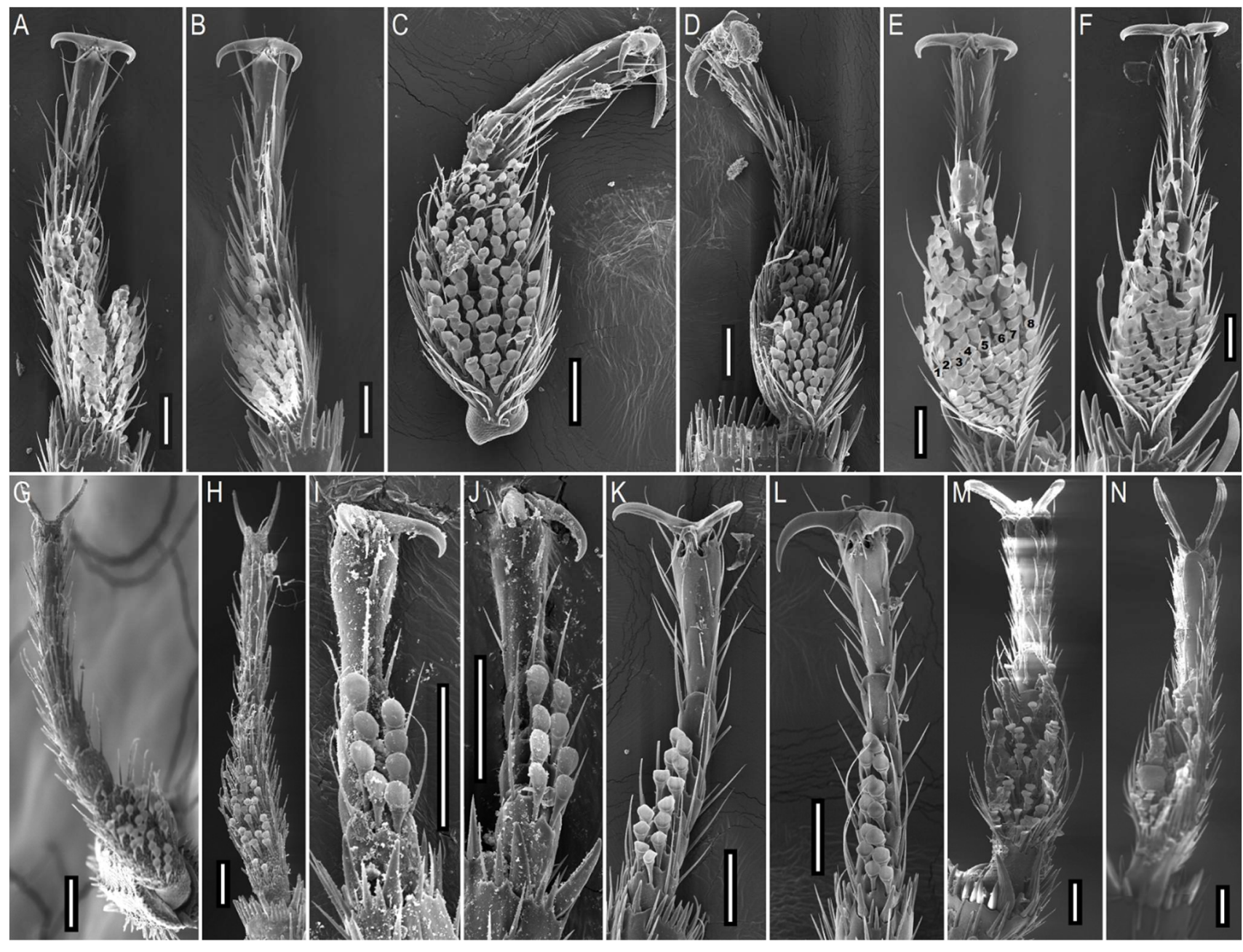

Fig. 6 

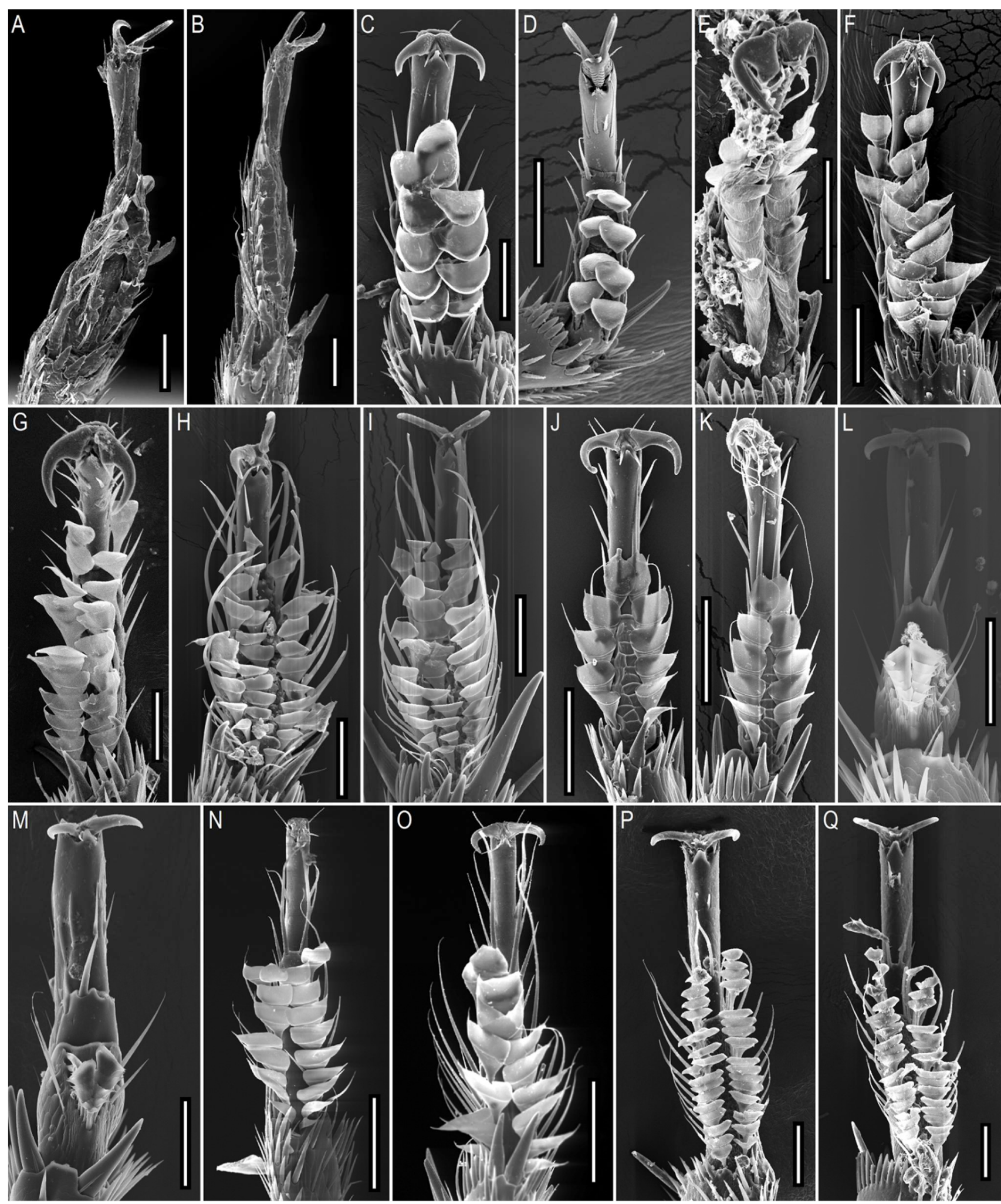

Fig. 7 


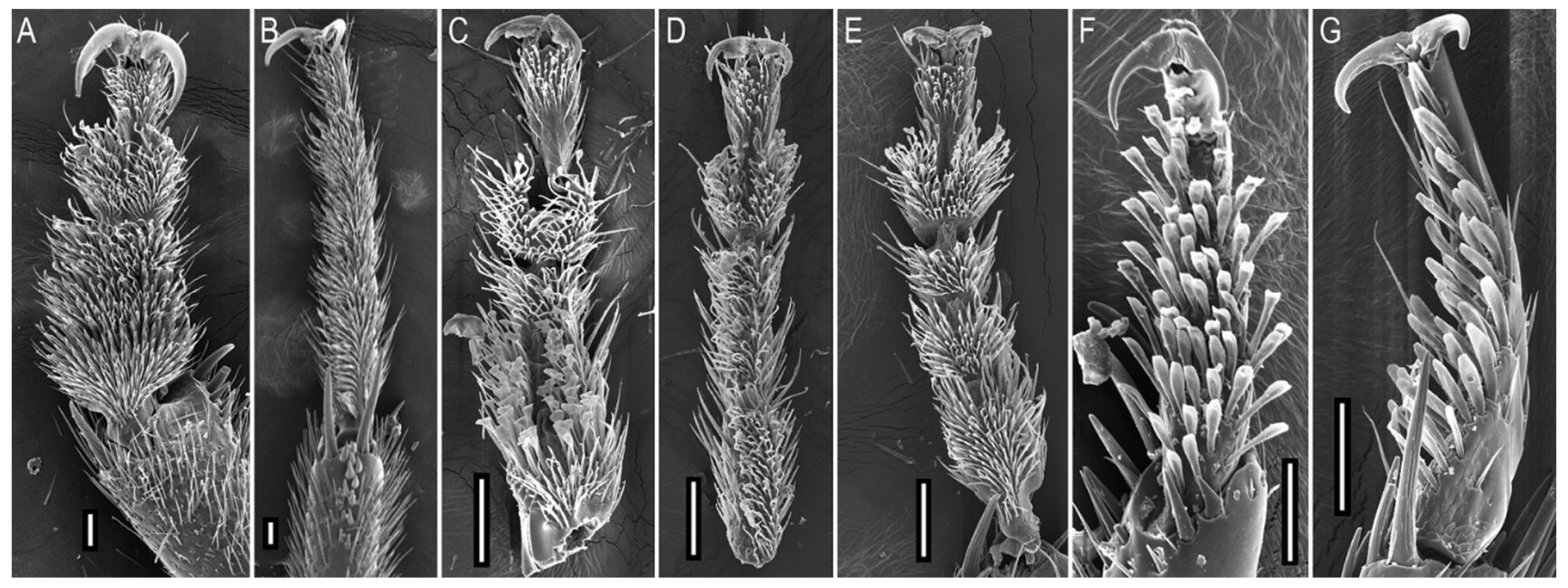

Fig. 8 

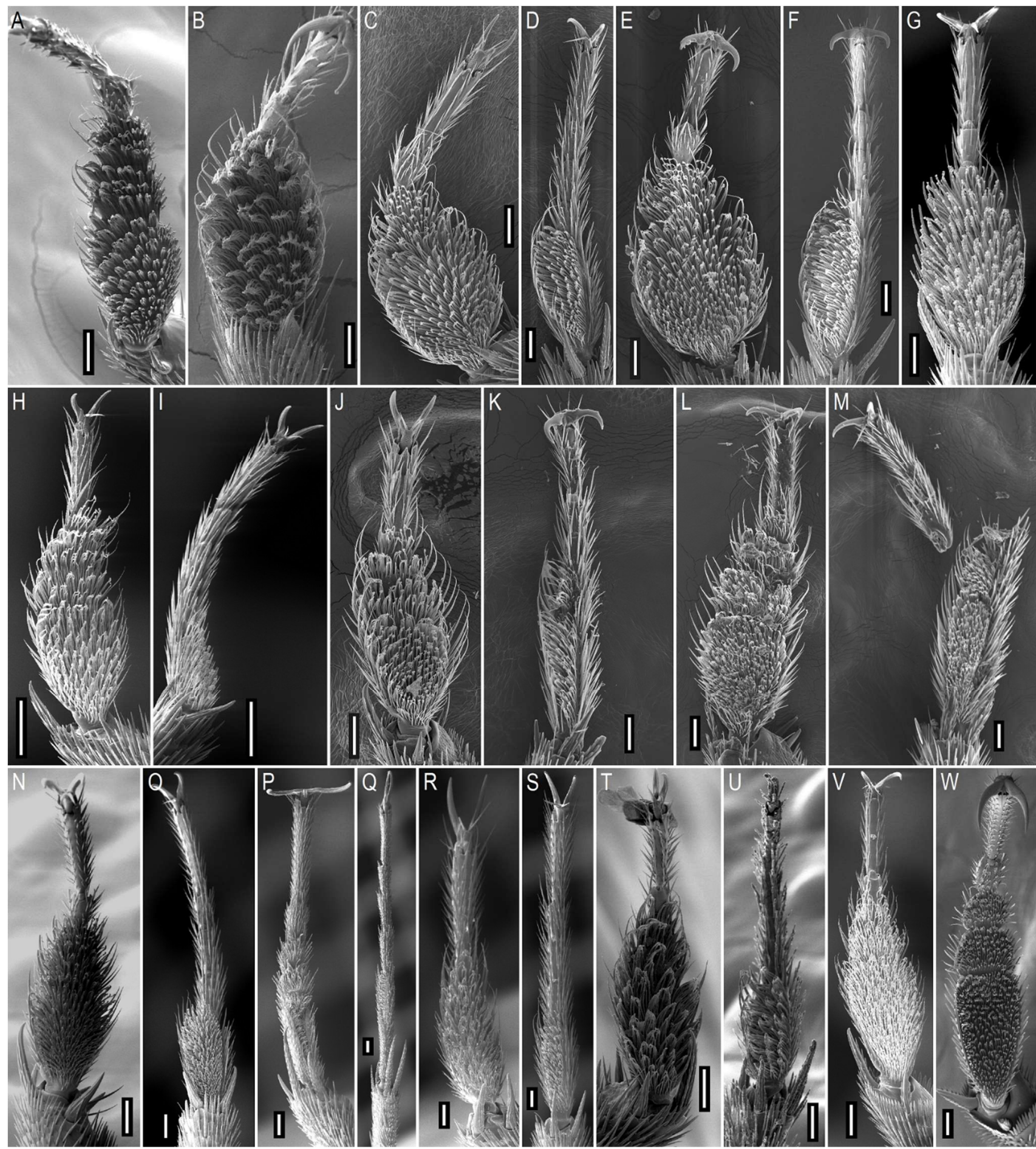

Fig. 9 

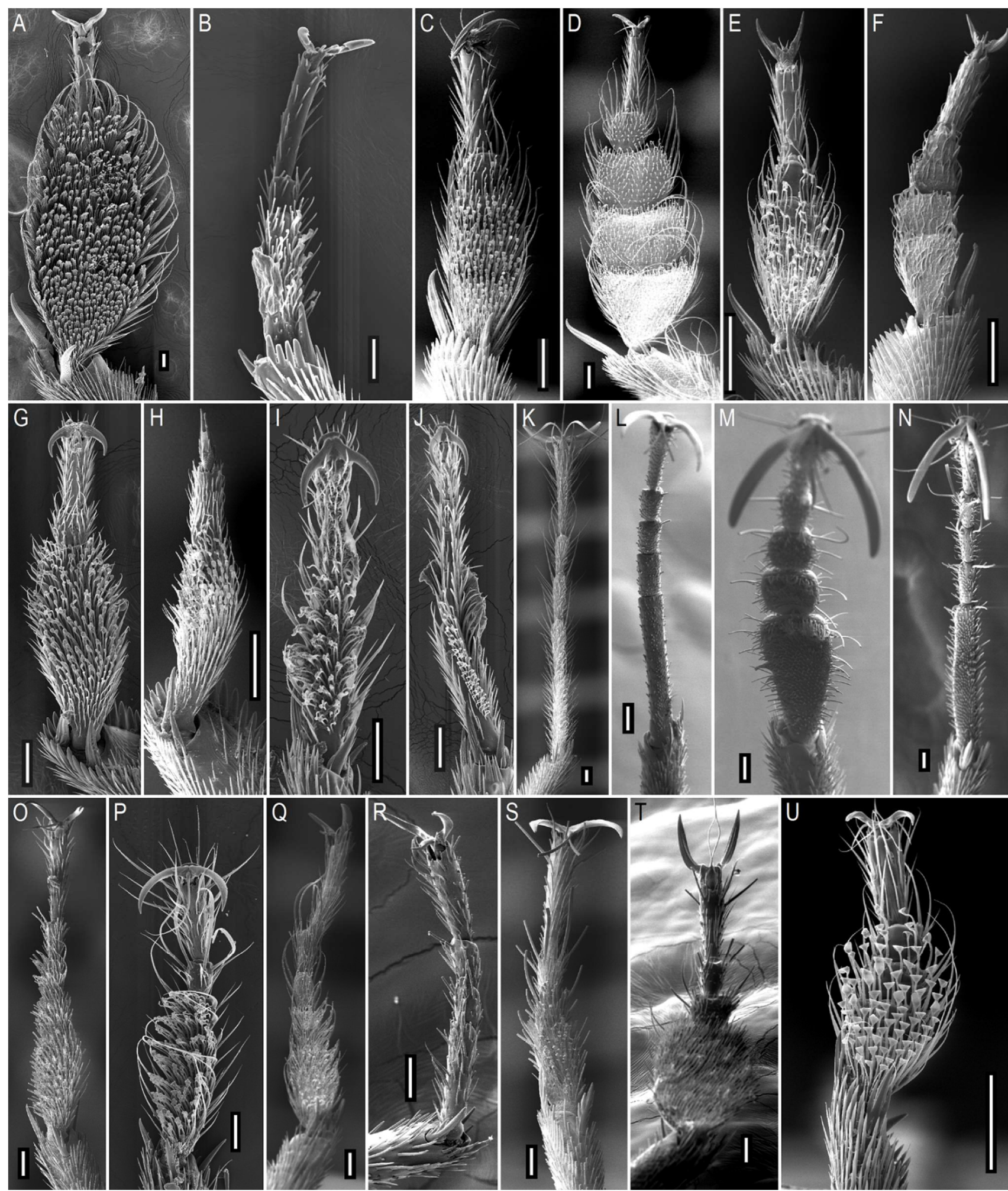

Fig. 10 

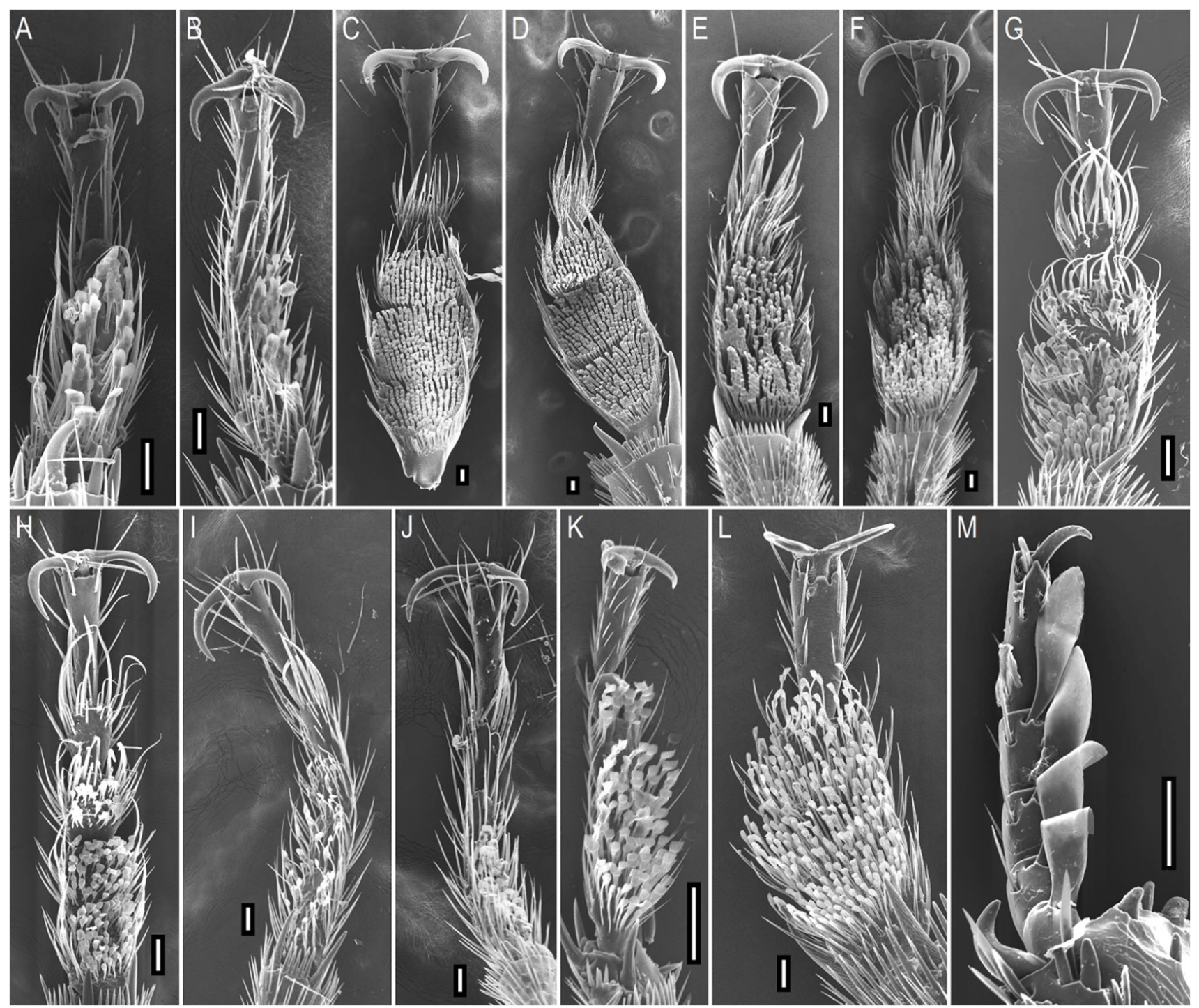

Fig. 11 


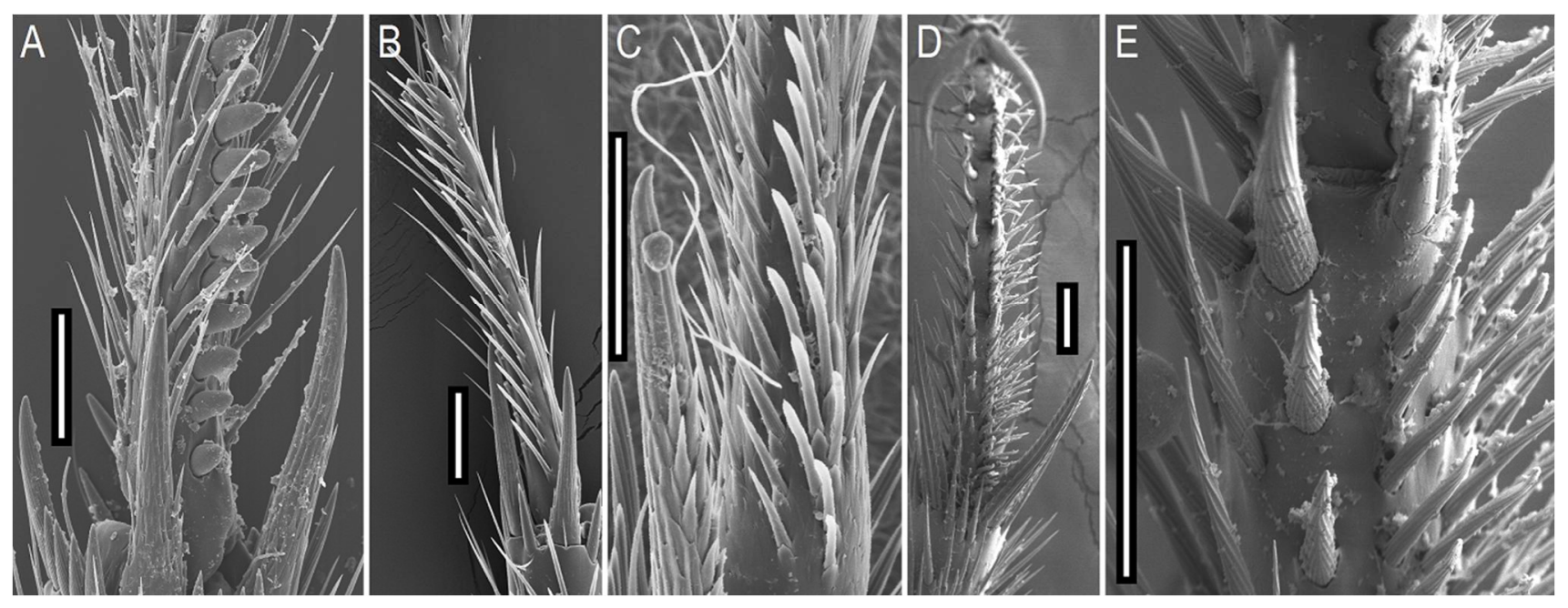

Fig. 12 


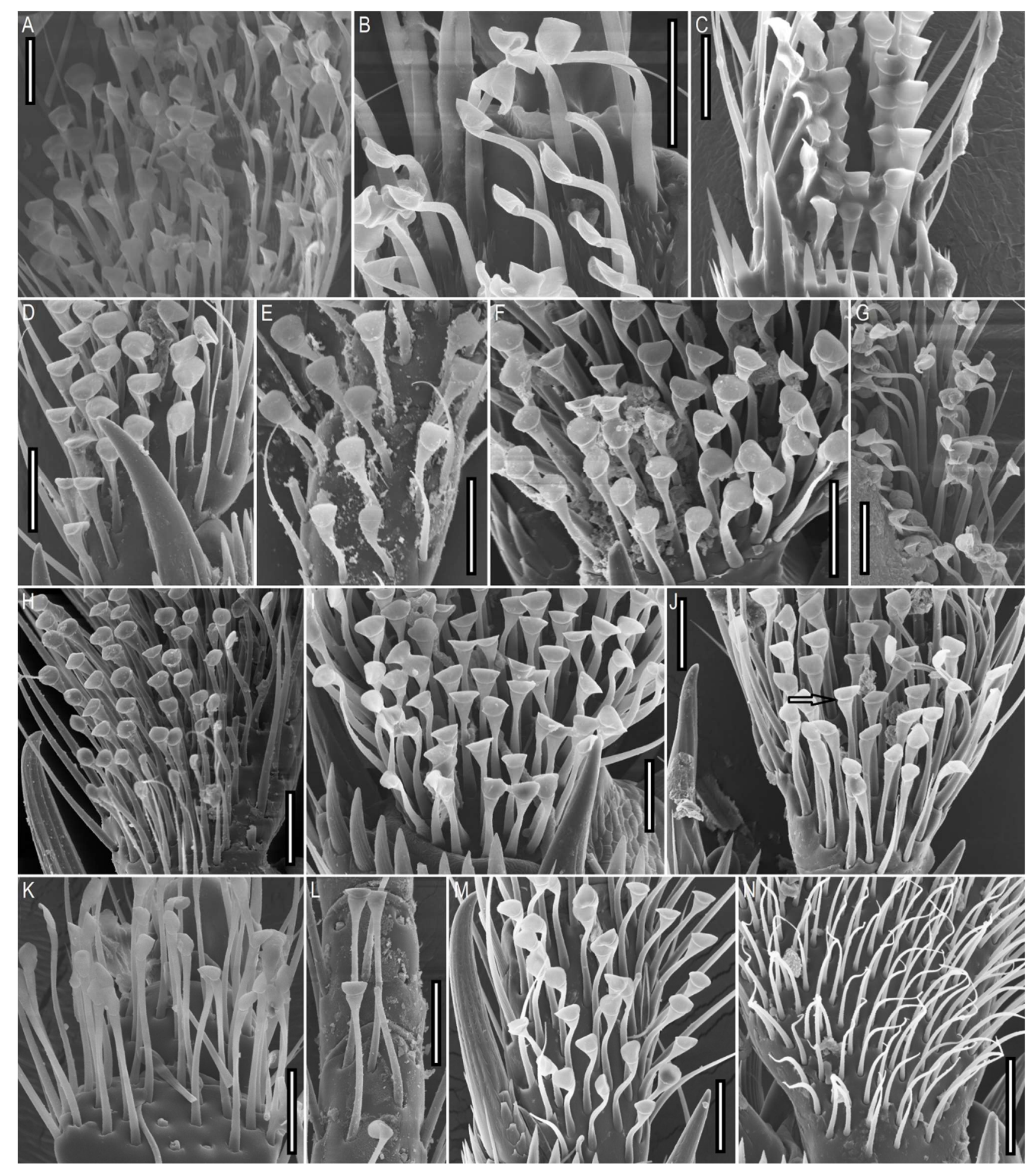

Fig. 13 


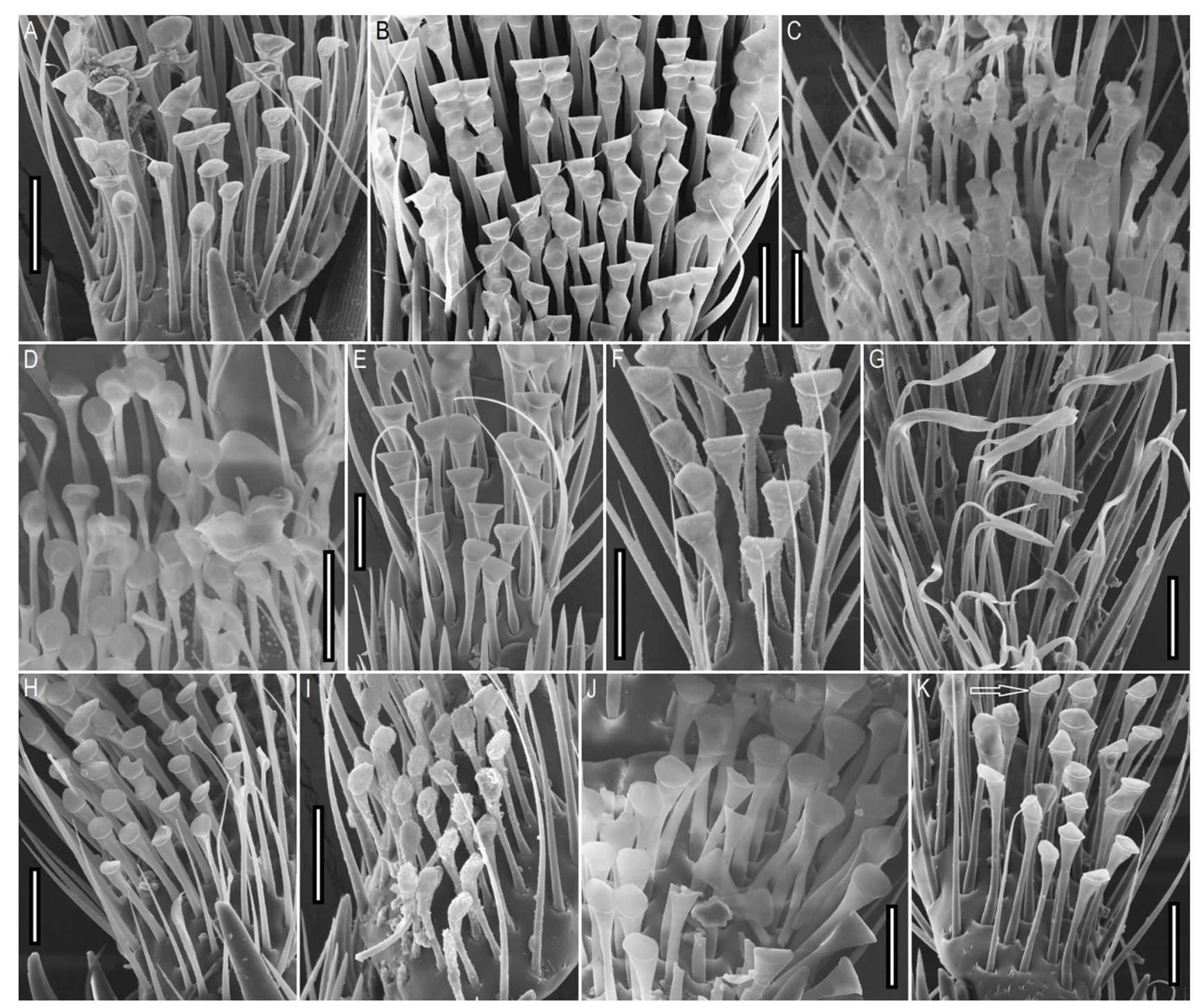

Fig. 14 
CAPÍTULO 4

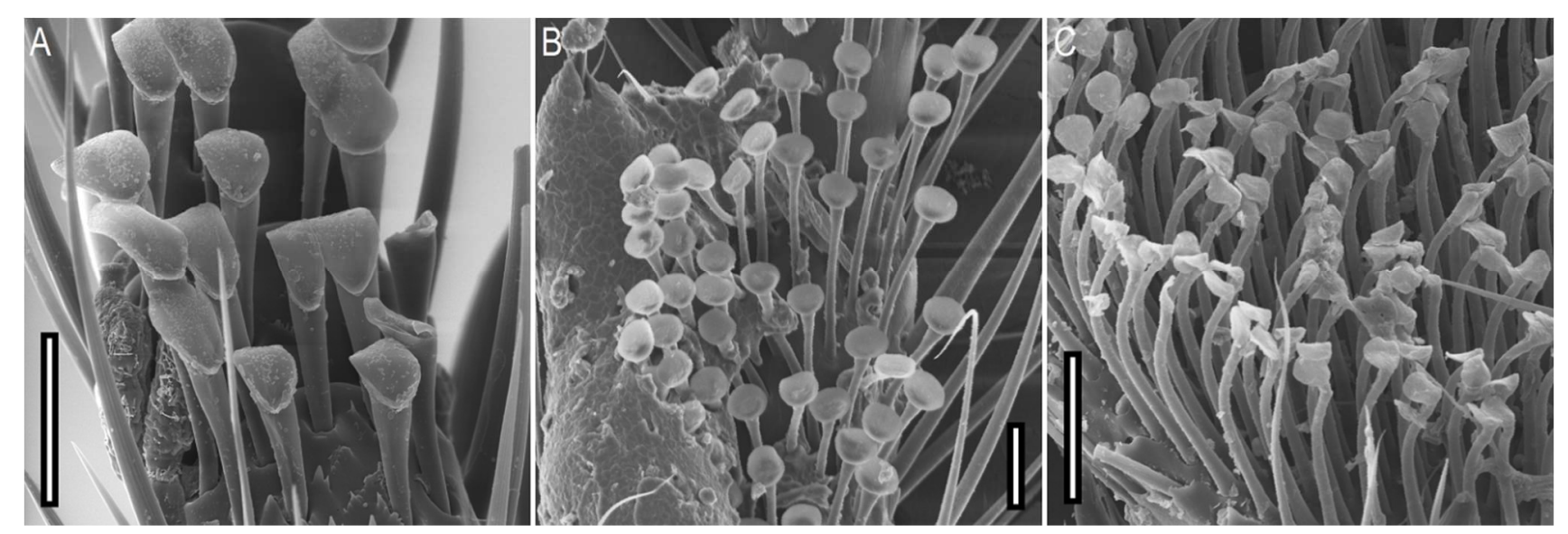

Fig. 15 


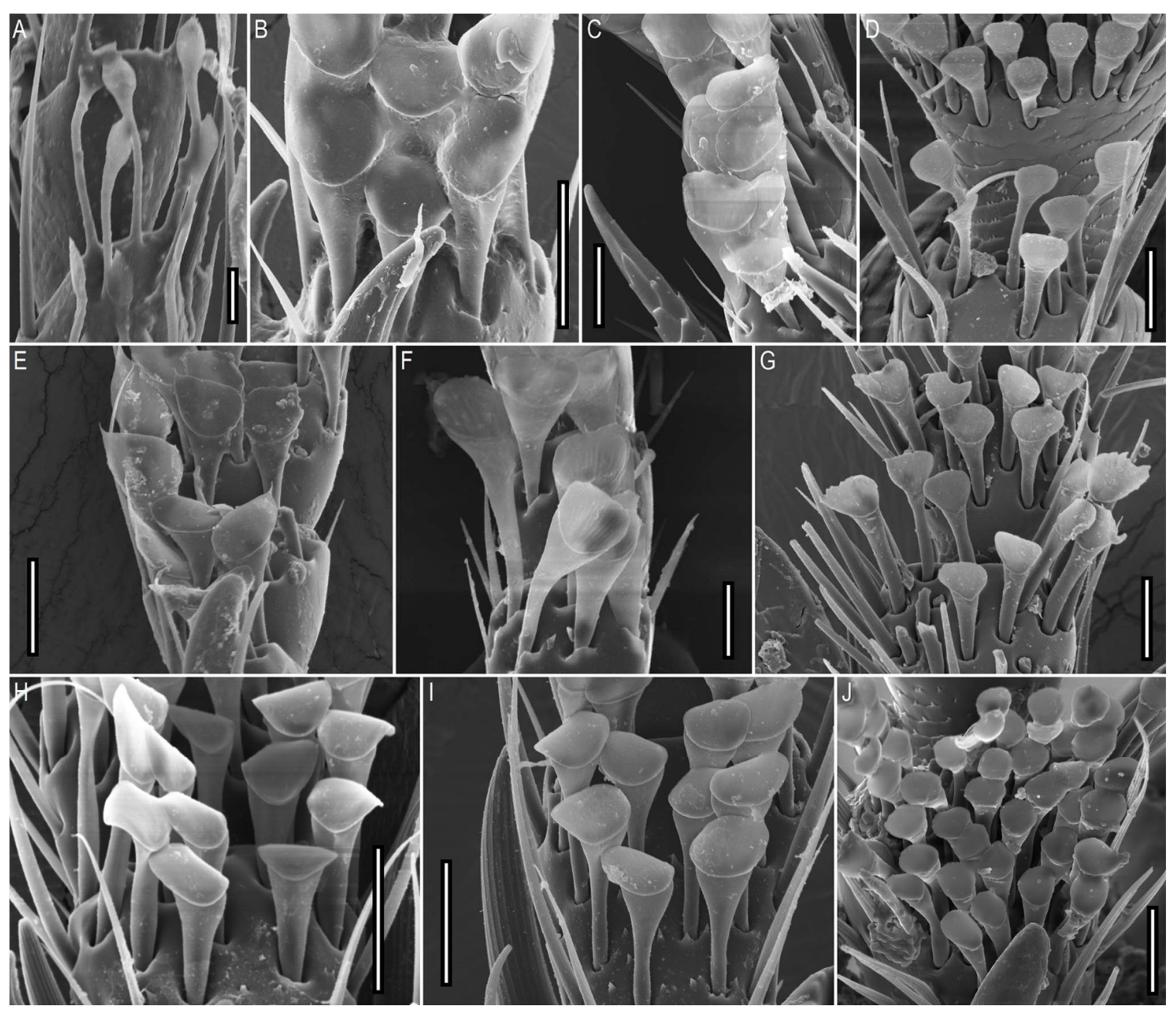

Fig. 16 
CAPÍTULO 4

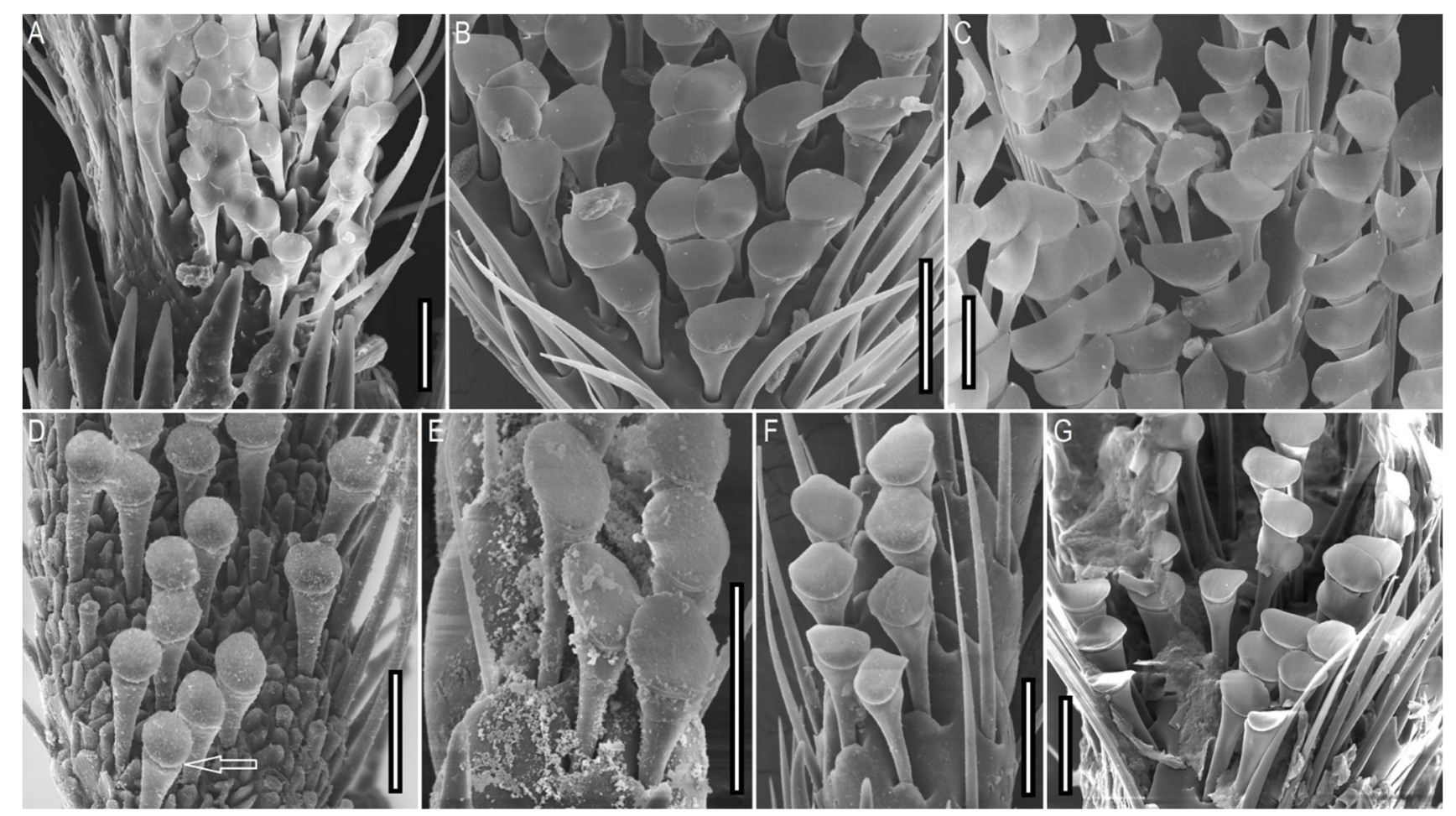

Fig. 17 


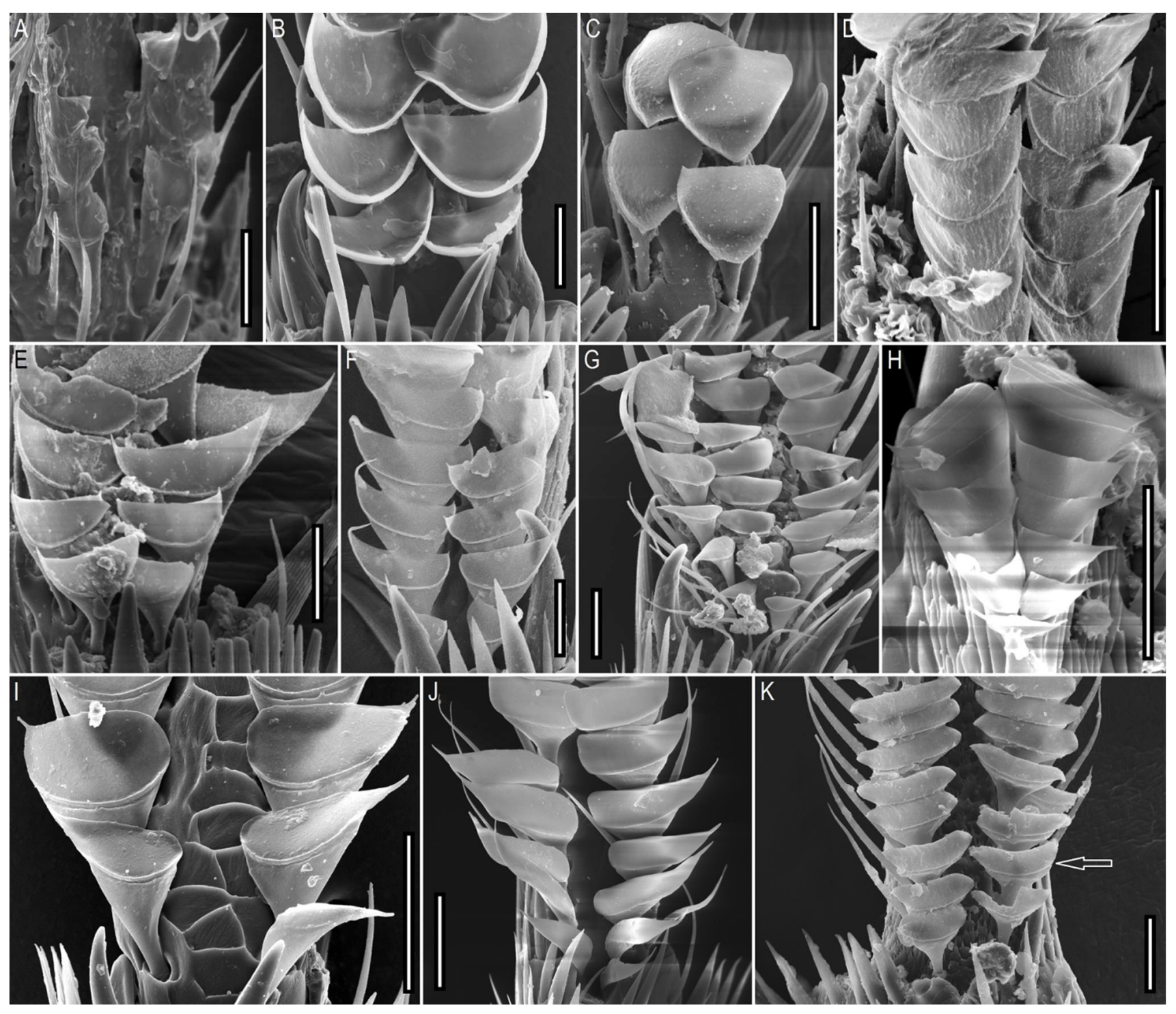

Fig. 18 
CAPÍTULO 4

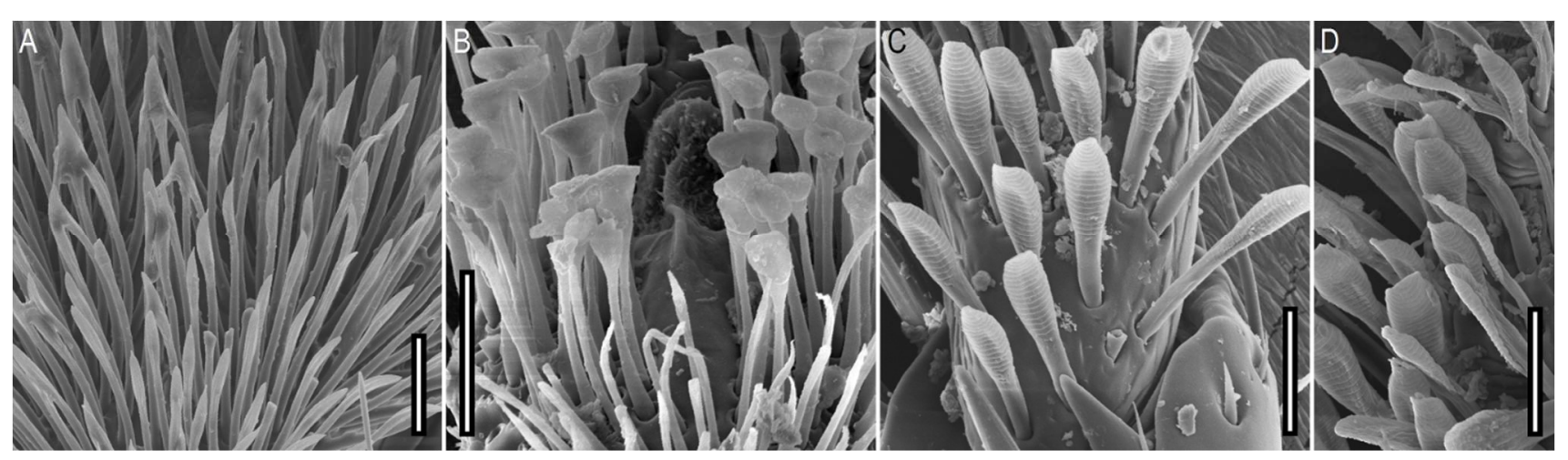

Fig. 19 


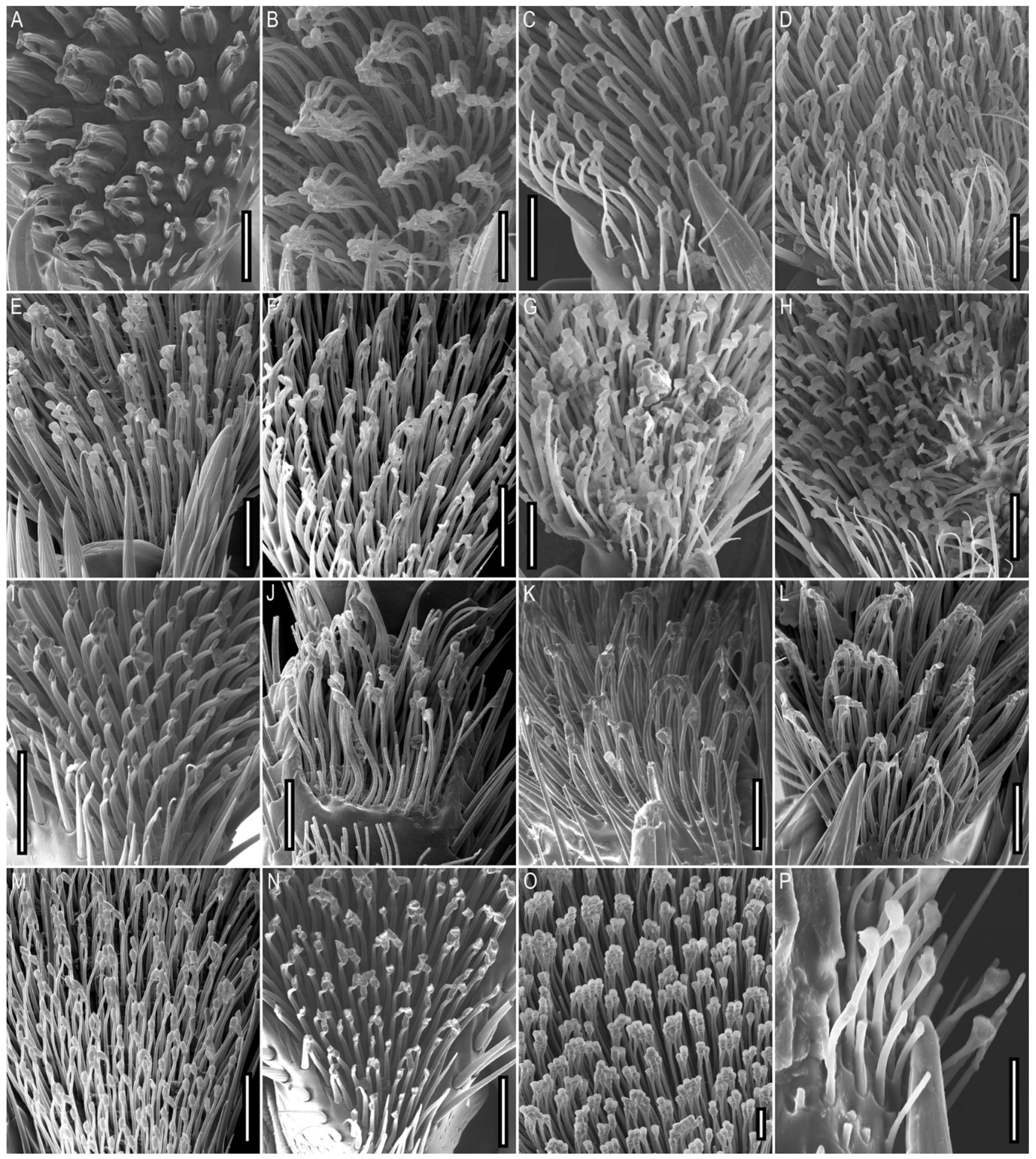

Fig. 20 


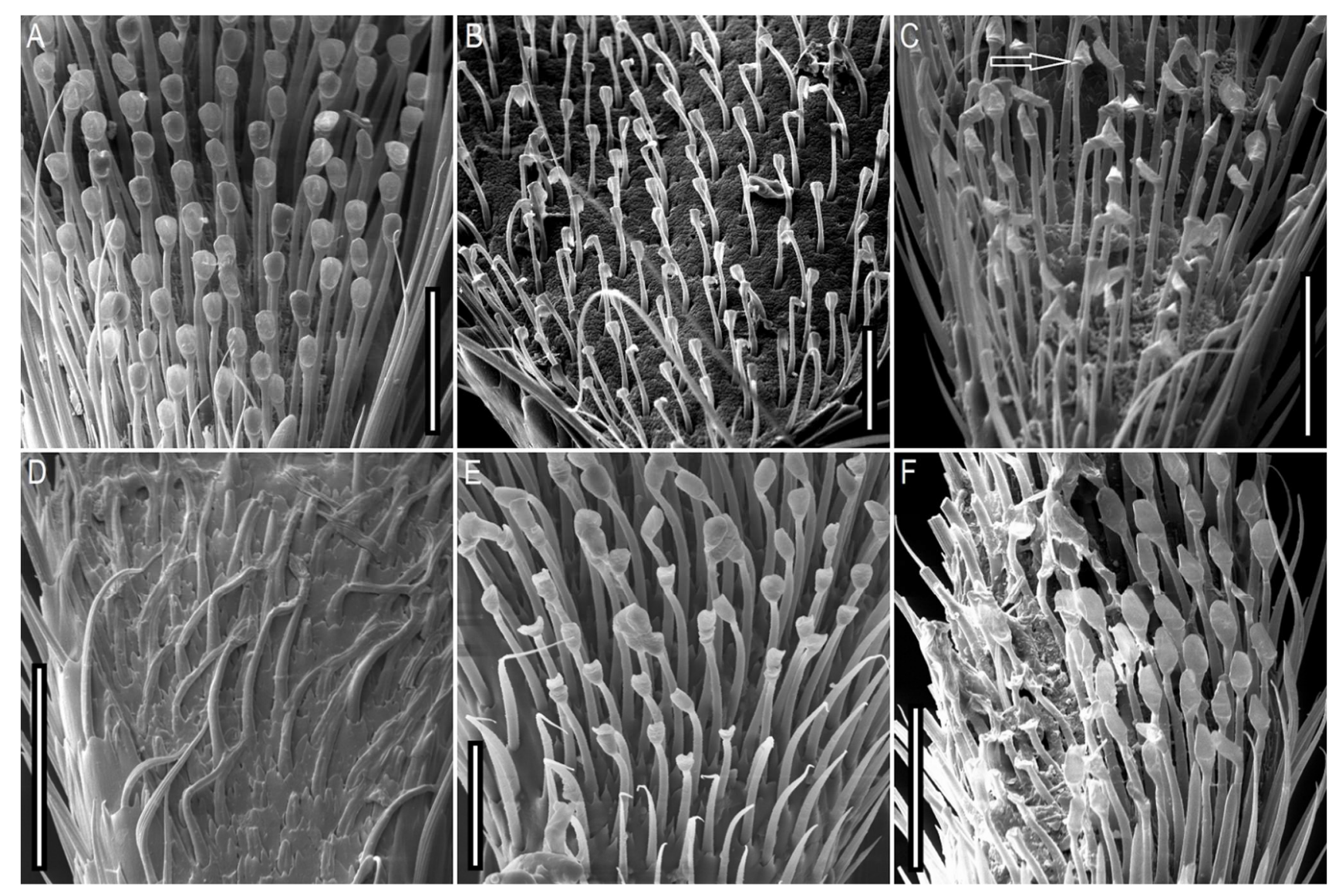

Fig. 21 


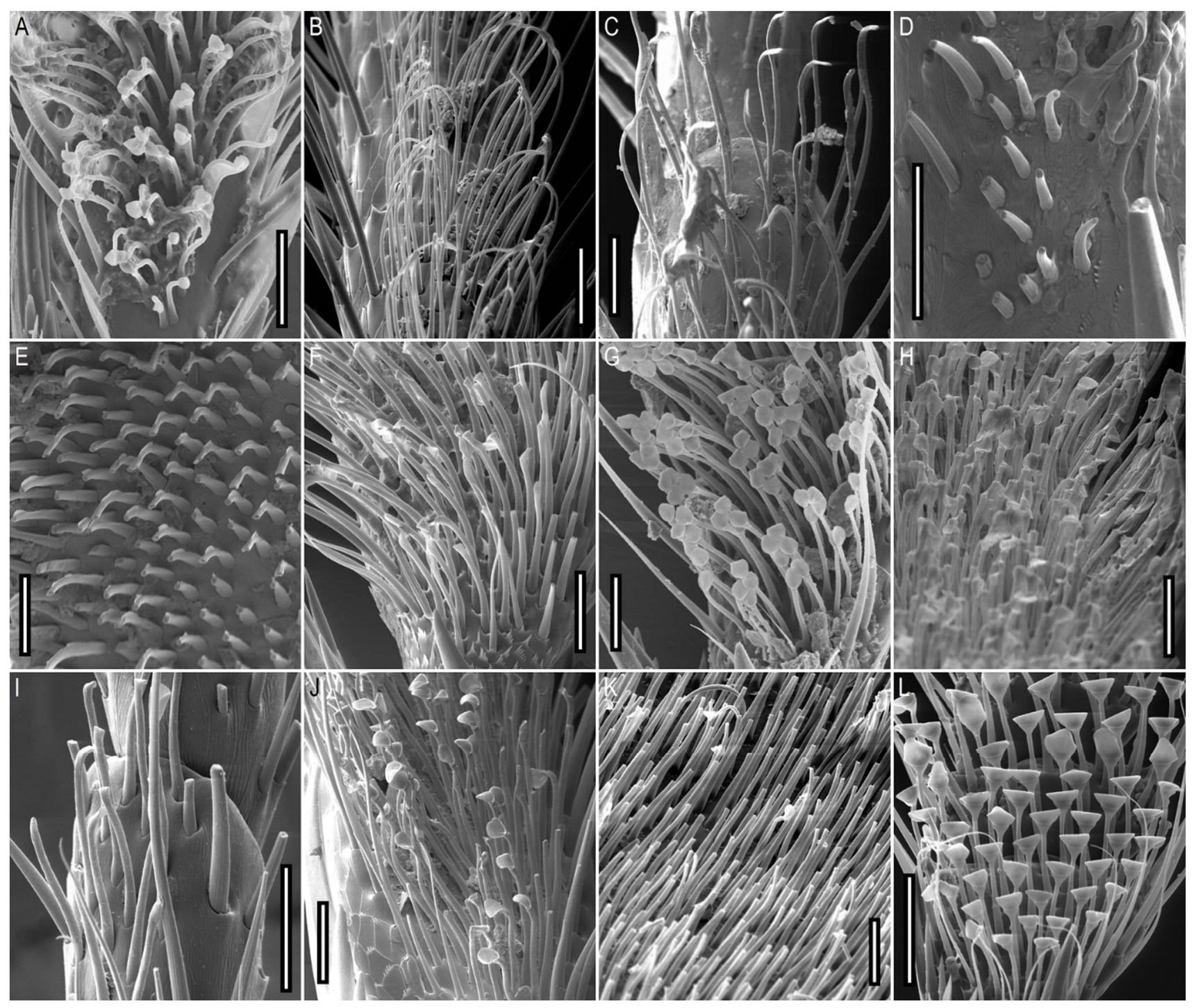

Fig. 22 


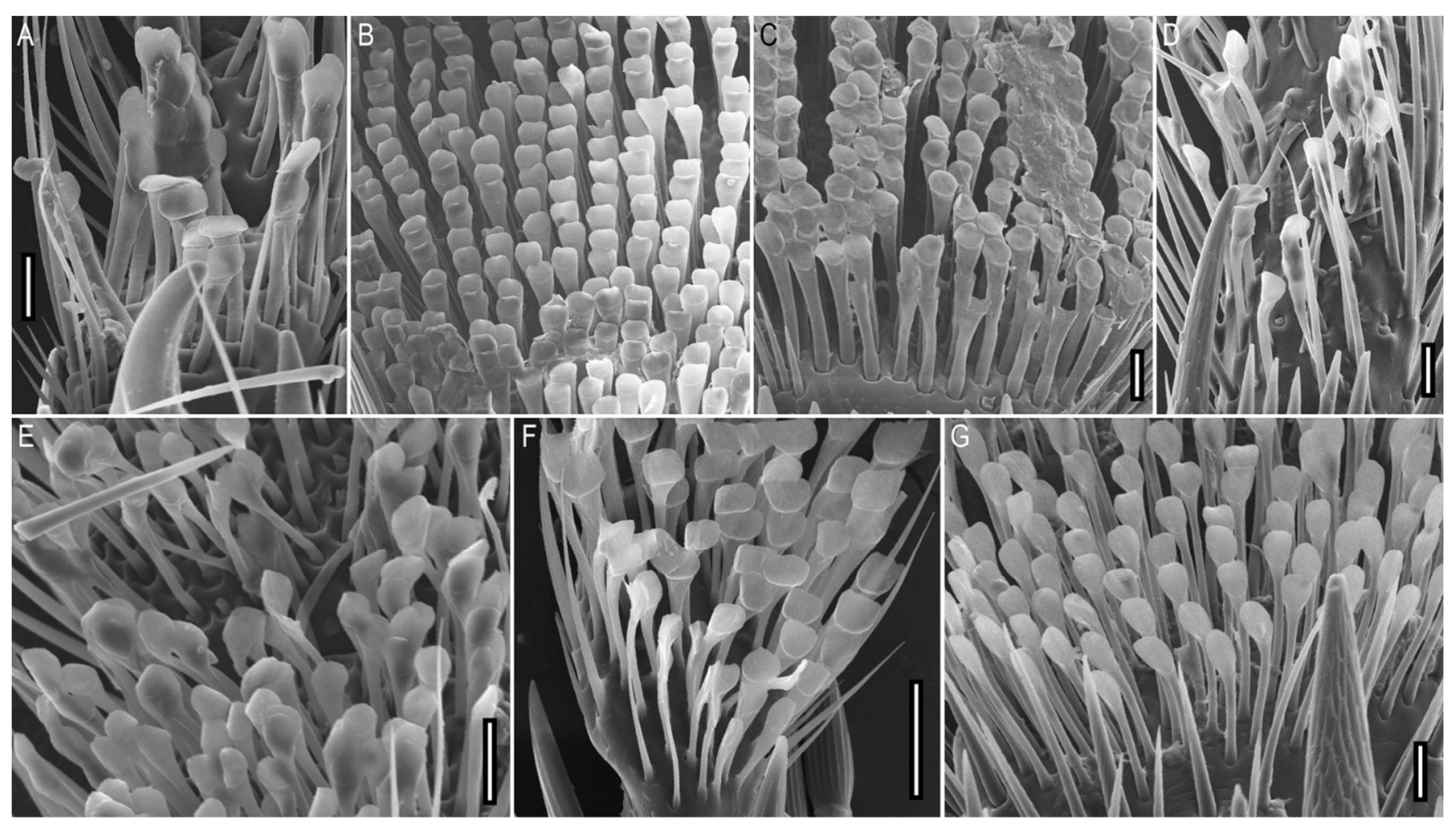

Fig. 23 

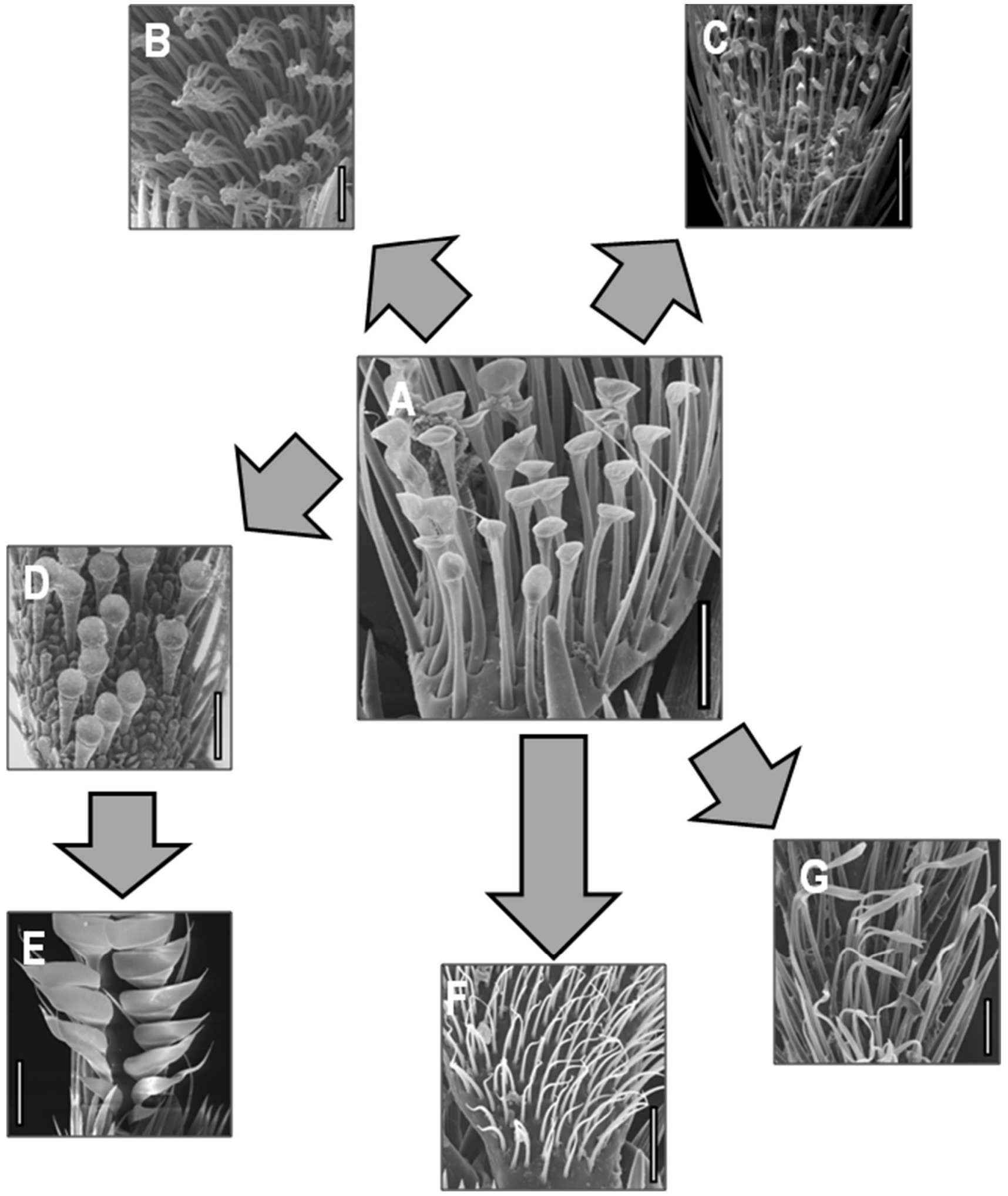

Fig. 24 


$$
\begin{aligned}
& \text { CONSIDERAÇÕ ES } \\
& \text { FINAIS }
\end{aligned}
$$



Até o desenvolvimento desta tese, o retrato que se tinha sobre a morfologia de Cholevinae e suas relações internas derivava predominantemente da literatura taxonômica, a qual se caracteriza pelo grande volume de informações sobre a morfologia da genitália, além de caracteres da morfologia externa geralmente fáceis de serem visualizados. Neste contexto, as discussões sobre interrelações de tribos e subtribos se balizavam, em sua maior parte, na reinterpretação desses caracteres e na tentativa de reconhecer o estado apomórfico objetivando alcançar um esquema taxonômico mais adequado (e.g. Jeannel, 1936; Perreau, 1989; Giachino \& Vailati, 1993; Giachino et al., 1998; Newton, 1998). Recentemente, estudos filogenéticos com base em dados moleculares lançaram alguma luz sobre as relações internas em Cholevinae (Fresneda et al., 2011; McKenna et al., 2015). Contudo, foram explicitamente direcionados a grupos mais, ou menos, inclusivos, portanto tratando apenas superficialmente das relações supragenéricas da subfamília.

Desta forma, esta tese propôs uma investigação abrangente sobre a morfologia de Cholevinae, visando sua aplicação em um contexto filogenético. O estudo sobre o pretarso e margem distal do tarsômero terminal constitui uma das raras investigações comparativas do pretarso em Coleoptera, e foi uma das primeiras a tratar do potencial da margem distal do tarsômero terminal para a sistemática de um grupo de insetos. Tal contribuição trouxe à tona um promissor sistema de caracteres para a sistemática supragenérica de Cholevinae. A arquitetura dos escleritos e cerdas empodiais, a forma e composição das projeções mediais dos tarsômero terminais, e a estrutura das garras e espinhos associados provaram desempenhar um papel relevante do ponto de vista taxonômico, servindo como uma ferramenta para identificação de tribos, subtribos e até de gêneros em alguns casos. Até então, nos poucos estudos filogenéticos envolvendo grupos internos de Cholevinae, apenas um único caráter do pretarso havia sido empregado (e sua validade foi questionada em nosso estudo). 
A investigação sobre a morfologia cefálica de Catops é inédita em Cholevinae, e revelou a natureza predominantemente plesiomórfica de sua composição muscular. Comparações com outras linhagens de Staphyliniformia sugerem que, de fato, a anatomia cefálica é altamente conservada no grupo. O mesmo se aplica à caracterização geral das estruturas da boca, epi- e hipofaringe, cuja homogeneidade morfológica dentro de Staphylinoidea associa-se à alimentação de partículas pequenas. Este trabalho oferece bases para pesquisas subsequentes interessadas em investigar as relações entre grandes grupos de Leiodidae tendo por base caracteres da cabeça. Com o contínuo avanço do conhecimento filogenético em Staphylinoidea - evidenciado por estudos recentes como o de McKenna et al. (2015) - a disponibilidade de dados sobre a morfologia cefálica das mais diferentes linhagens oferecerá uma preciosa oportunidade de se entender a evolução do tagma mais complexo dos insetos neste clado altamente diverso, e a linhagem dos Cholevinae poderá ser representada neste cenário.

Frente ao conhecimento filogenético que se tinha sobre Cholevinae, esta tese traz duas novidades em relação aos esforços anteriores. Representa não apenas a primeira hipótese filogenética com base em morfologia, como também a primeira análise cladística com foco na subfamília como um todo. Nossas análises confirmaram algumas hipóteses anteriores, mas principalmente revelaram uma nova visão sobre as dicotomias basais, o monofiletismo de tribos e subtribos, e suas interrelações. O posicionamento basal de Eucatopini e Oritocatopini foi demonstrado, e o monofiletismo do clado envolvendo as tribos restantes foi corroborado (confirmando hipóteses anteriores, e.g. Fresneda et al., 2011 e McKenna et al., 2015). As análises indicaram que Anemadini é polifilético, e que os gêneros de Cholevini formam um agrupamento monofilético com a exclusão de Cholevinus e possivelmente de Prionochaeta. O estudo também sugere a proximidade de Ptomaphagini com Sciaphyini e Leptodirini, mas indica que o posicionamento de Sciaphyes ainda é incerto. Mostramos que grande parte dos caracteres usados na análise filogenética foi extraída da face ventral dos espécimes, evidenciando a relevância da documentação das partes ventrais em descrições taxonômicas (em contraposição ao hábito comum de apenas 
apresentar ilustrações em vista dorsal). Com a inclusão de representantes de todos os táxons supragenéricos, a hipótese filogenética apresentada é a mais abrangente para a subfamília até então.

De forma similar ao estudo do pretarso em Cholevinae, a ampla análise das cerdas sexuais tarsais em Leiodidae mostrou o potencial dessa estrutura como uma fonte de caracteres para a sistemática supragenérica da família. O estudo da ocorrência dessas cerdas no pro- e mesotarso, e suas variações de forma e disposição entre os vários grupos de Leiodidae indicam caracteres que sustentam a subfamília Leiodinae como um grupo monofilético, assim como suportam agrupamentos internos envolvendo suas tribos. Implicações para outros táxons também foram apontadas, como em Cholevinae, Catopocerinae e Platypsyllinae.

\section{CONCLUSÕES}

Em conjunto, os dados aqui apresentados sinalizam como era incipiente o conhecimento da morfologia e relações filogenéticas em Cholevinae, e o mesmo parece se aplicar a Leiodidae. Além disso, nossas análises denotam que a classificação supragenérica proposta por Newton $(1998,2016)$, a mais utilizada atualmente para a subfamília, não está completamente sustentada por um arcabouço filogenético. Embora acreditamos trazer notáveis contribuições para o conhecimento da morfologia e sistemática de Cholevinae, algumas questões ainda aguardam ser elucidadas. Dentre essas, o posicionamento filogenético de Sciaphyini e as obscuras relações genéricas dentro do clado altamente diverso dos Leptodirini do Velho Mundo parecem ser as mais recalcitrantes. Dessa forma, a integração de dados morfológicos e moleculares deve ser o próximo passo para alcançarmos uma classificação mais robusta da subfamília e desatar os nós que restaram. Em suma, esta tese demonstra que investigações minuciosas de componentes morfológicos específicos podem revelar novas fontes de informação filogenética em diferentes níveis taxonômicos. 


\section{REFERÊNCIAS}

Fresneda, J., Grebennikov, V.V. \& Ribera, I. 2011. The phylogenetic and geographic limits of Leptodirini (Insecta: Coleoptera: Leiodidae: Cholevinae), with a description of Sciaphyes shestakovi sp. n. from the Russian Far East. Arthropod Systematics and Phylogeny, 69: 99-123.

Giachino, P.M. \& Vailati, D. 1993. Revisione degli Anemadinae. Monografia di Natura Bresciana, 18: 7-314.

Giachino, P.M., Vailati, D. \& Casale, A. 1998. Major questions in the phylogeny and biogeography of Cholevidae (Coleoptera), with emphasis on the subfamily Leptodirinae. Museo Regionale di Scienze Naturali di Torino Atti, 8: 179-210.

Jeannel, R. 1936. Monographie des Catopidae. Mémoires du Muséum National d'Histoire Naturelle (n.s.), 1: 1-433.

McKenna, D.D., Farrell, B.D., Caterino, M.S., Farnum, C.W., Hawks, D.C., Maddison, D.R., Seago, A.E., Short, A.E.Z., Newton, A.F. \& Thayer, M.K. 2015. Phylogeny and evolution of Staphyliniformia and Scarabaeiformia: forest litter as a stepping stone for diversification of nonphytophagous beetles. Systematic Entomology, 40: 35-60.

Newton, A.F., 1998. Phylogenetic problems, current classification and generic catalog of World Leiodidae (including Cholevidae). Museo Regionale di Scienze Naturali di Torino Atti, 8, 41-177.

Newton, A.F., 2016. Leiodidae Fleming, 1821. In: Beutel, R.G. and Leschen, R.A.B. (Eds.), Handbook of Zoology, Vol. IV, Arthropoda: Insecta; Coleoptera, Morphology and Systematics (Archostemata, Adephaga, Myxophaga, Polyphaga partim), Vol. 1, 2nd ed. Walter De Gruyter, Berlin and New York, pp. 364-376.

Perreau, M., 1989. De la phylogénie des Cholevidae et des familles apparentées (Coleoptera, Cholevidae). Archives des Sciences, Genève, 39: 579-590. 
